\title{
Site U1376
}

\author{
Expedition 330 Scientists $^{2}$
}

\section{Chapter contents}

Background and objectives. ......... 1

Operations.................... 2

Sedimentology ................ 3

Paleontology ................6 6

Igneous petrology and volcanology . . . . . 8

Alteration petrology . . . . . . . . . . . 11

Structural geology. . . . . . . . . . . 14

Geochemistry ................. 15

Physical properties .............. 17

Paleomagnetism ................ 20

Downhole logging . . . . . . . . . . 23

Microbiology ................. 29

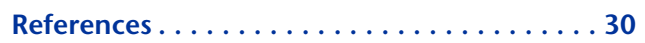

Figures...................... 34

Tables....................... 112

'Expedition 330 Scientists, 2012. Site U1376. In Koppers, A.A.P., Yamazaki, T., Geldmacher, J., and the Expedition 330 Scientists, Proc. IODP, 330: Tokyo (Integrated Ocean Drilling Program Management International, Inc.).

doi:10.2204/iodp.proc.330.107.2012

'Expedition 330 Scientists' addresses.

\section{Background and objectives}

Site U1376 (alternate prospectus Site LOUI-7A) on Burton Guyot (Fig. F1) was the fifth site drilled during Integrated Ocean Drilling Program (IODP) Expedition 330. This site and seamount have an estimated age of $\sim 63-65 \mathrm{Ma}$, slightly older than Site U1375 on Achernar Guyot. As with Site U1375, new age data from Burton Guyot will fill an important gap in the age-versus-distance relationship of the Louisville Seamount Trail, providing information pivotal to reconstructing past plate motion and the motion of the Louisville hotspot. Burton and Achernar Guyots have structural bases $<30 \mathrm{~km}$ in diameter, making them two of the smaller volcanoes in the Louisville Seamount Trail. Site U1376 on Burton Guyot was targeted in the middle of this small edifice (Fig. F2), away from the guyot's shelf edges and any packages of dipping volcaniclastics on its flanks, the latter of which were targeted at Sites U1372, U1373, and U1374. The summit of Burton Guyot is characterized by two pedestals on its northeastern and southeastern ends, between which Site U1376 was placed at $1503 \mathrm{~m}$ water depth (Fig. F2). Burton Guyot shows no evidence of tilting. Sidescan sonar reflectivity and $3.5 \mathrm{kHz}$ subbottom profiling data indicate that Site U1376 is covered with $<10 \mathrm{~m}$ of pelagic sediment, and seismic reflection profiles suggest that this central part of Burton Guyot has a $<110 \mathrm{~m}$ thick sequence of reflectors (volcaniclastics?) overlying igneous basement.

The original drilling plan was to recover soft sediment using a gravity-push approach with little or no rotation of the rotary core barrel assembly, followed by standard coring into the volcaniclastic materials and down to $350 \mathrm{~m}$ into igneous basement. A short downhole logging series was planned, including the standard triple combination and Formation MicroScanner-sonic tool strings and the third-party Göttingen Borehole Magnetometer tool. Drilling and logging were successfully accomplished after drilling to 182.8 meters below seafloor (mbsf) and carrying out the planned logging program. Coring was particularly successful, with an average recovery of $76 \%$ in igneous basement.

\section{Objectives}

Drilling during Ocean Drilling Program (ODP) Leg 197 provided compelling evidence for the motion of mantle plumes by documenting a large $\sim 15^{\circ}$ shift in paleolatitude for the Hawaiian hotspot (Tarduno et al., 2003; Duncan et al., 2006). This evidence 
led to testing two geodynamic end-member models during Expedition 330, namely that the Louisville and Hawaiian hotspots moved coherently over geological time (Courtillot et al., 2003; Wessel and Kroenke, 1997) or, quite the opposite, that these hotspots show considerable interhotspot motion, as predicted by mantle flow models (Steinberger, 2002; Steinberger et al., 2004; Koppers et al., 2004; Steinberger and Antretter, 2006; Steinberger and Calderwood, 2006). The most important objective of Expedition 330, therefore, was to core deep into the igneous basement of four seamounts in the Louisville Seamount Trail in order to sample a large number of in situ lava flows ranging in age between 80 and $50 \mathrm{Ma}$. With a sufficiently large number of these independent cooling units, high-quality estimates of their paleolatitude can be determined, and any recorded paleolatitude shift (or lack thereof) can be compared with seamounts in the Hawaiian-Emperor Seamount Trail. For this reason, Expedition 330 mimicked the drilling strategy of Leg 197 by drilling seamounts equivalent in age to Detroit (76-81 Ma), Suiko (61 Ma), Nintoku (56 Ma), and Koko (49 Ma) Seamounts in the Emperor Seamount Trail. Accurate paleomagnetic inclination data for the drilled seamounts are required in order to establish a record of past Louisville hotspot motion, and, together with high-resolution ${ }^{40} \mathrm{Ar} /{ }^{39} \mathrm{Ar}$ age dating of the cored lava flows, these data will help us constrain the paleolatitudes of the Louisville hotspot between 80 and 50 Ma. These comparisons are of fundamental importance in determining whether these two primary hotspots have moved coherently or not and in understanding the nature of hotspots and convection in the Earth's mantle.

Expedition 330 also aimed to provide important insights into the magmatic evolution and melting processes that produced and constructed Louisville volcanoes as they progressed from shield to postshield, and perhaps posterosional, volcanic stages. Existing data from dredged lava suggest that the mantle source of the Louisville hotspot has been remarkably homogeneous for as long as 80 m.y. (Cheng et al., 1987; Hawkins et al., 1987; Vanderkluysen et al., 2007; Beier et al., 2011). In addition, all dredged basalt is predominantly alkalic and possibly represents a mostly alkalic shield-building stage, in contrast to the tholeiitic shield-building stage of volcanoes in the Hawaiian-Emperor Seamount Trail (Hawkins et al., 1987; Vanderkluysen et al., 2007; Beier et al., 2011). Therefore, the successions of lava flows cored during Expedition 330 will help us characterize the Louisville Seamount Trail as the product of a primary hotspot and test the long-lived homogeneous geochemical character of its mantle source. Analyses of melt inclusions, volcanic glass samples, high-Mg olivine, and clinopyroxene phenocrysts will provide further constraints on the asserted homogeneity of the Louisville plume source, its compositional evolution between 80 and $50 \mathrm{Ma}$, its potential mantle plume temperatures, and its magma genesis, volatile outgassing, and differentiation. Incremental heating ${ }^{40} \mathrm{Ar} /{ }^{39} \mathrm{Ar}$ age dating will allow us to establish age histories within each drill core, delineating any transitions from the shield-building phase to the postshield capping and posterosional stages.

Finally, basalt and sediment cored at Site U1376 were planned for use in a range of secondary objectives, such as searching for active microbial life in the old seamount basement and determining whether fossil traces of these microbes were left behind in volcanic glass or rock biofilms. We also planned to determine ${ }^{3} \mathrm{He} /{ }^{4} \mathrm{He}$ and ${ }^{186} \mathrm{Os} /{ }^{187} \mathrm{Os}$ signatures of the Louisville mantle plume to evaluate its potential deep-mantle origin, to use oxygen and strontium isotope measurements on carbonates and zeolites in order to assess the magnitude of carbonate vein formation in aging seamounts and its role as a global $\mathrm{CO}_{2}$ sink, to age date celadonite alteration minerals for estimating the total duration of low-temperature alteration following seamount emplacement, and to determine the hydrogeological and seismological character of the seamount basement.

\section{Operations}

The $91 \mathrm{nmi}$ transit to Site U1376 on Burton Guyot was accomplished at an average speed of $10.1 \mathrm{kt}$. The vessel was on station at $2300 \mathrm{~h}$ on 26 January 2011 (all times are New Zealand Daylight Time, Universal Time Coordinated [UTC] $+13 \mathrm{~h}$ ). A three-stand rotary core barrel coring assembly was made up with a new C-4 coring bit and mechanical bit release and deployed. The vibration-isolated television (VIT) frame was launched before the hole was spudded in order to observe the character of the seafloor and the tagging of the bit on the bottom. A rocky seabed devoid of any appreciable sediment was observed on the VIT camera. From 0300 to 0515 h on 27 January a VIT survey was undertaken to look for an area containing sediment that could support a free-fall funnel installation (should one be later required). After $2.3 \mathrm{~h}$, a spot with a very small sediment pond was located.

The driller tagged the seafloor at 1514.3 meters below rig floor (mbrf; 1503.3 meters below sea level [mbsl]), $5.5 \mathrm{~m}$ deeper than the corrected precision depth recorder measurement, and Hole U1376A was spudded at $0705 \mathrm{~h}$ on 27 January (Table T1). Opera- 
tions continued without incident until $1530 \mathrm{~h}$ on 30 January, when coring was suspended at $86.8 \mathrm{mbsf}$ to change the bit, which had accumulated 72.4 rotating hours. Because of the absence of sediment cover needed to support a free-fall funnel installation, a hole marker composed of a weight, tether, and single glass float was placed on the seafloor from the VIT frame via an acoustic release. The bit cleared the seafloor at $1800 \mathrm{~h}$ on 30 January and was on deck at 2215 h. A new Type C-4 bit and a refurbished mechanical bit release were made up to the bottomhole assembly and deployed.

After the drill string was tripped to 1131 mbrf, the VIT frame was deployed and both were run to 1512 mbrf. The open hole was successfully reentered at $0435 \mathrm{~h}$ on 31 January. Coring resumed in Hole $\mathrm{U} 1376 \mathrm{~A}$ at $0630 \mathrm{~h}$ and continued without incident until the allocated coring time for this site expired at $1630 \mathrm{~h}$ on 2 February, leaving the hole at a final depth of $182.8 \mathrm{mbsf}$. The total average recovery for the hole was $74.5 \%$, with an excellent average recovery in basement of $75.6 \%$. The average rate of penetration in basement was $1.8 \mathrm{~m} / \mathrm{h}$. In accordance with expedition routine, nonmagnetic core barrels were used to obtain all cores. One microsphere packet was deployed in the core catcher of Core 330-U1376A$19 \mathrm{R}$ at $144.4 \mathrm{mbsf}$. Prior to the recovery of all cores except 2R, 3R, and 10R, $20 \mathrm{bbl}$ mud sweeps were circulated.

Following a wiper trip that displaced the borehole with $42 \mathrm{bbl}$ of heavy (10.5 ppg) mud, the bit was released at the bottom of the hole. The end of pipe was positioned at the logging depth of $80.4 \mathrm{mbsf}$ by 2115 h on 2 February.

The first log was conducted with the triple combination tool string, which logged the hole up from 181 mbsf in two passes. After this tool string was recovered at $0350 \mathrm{~h}$ on 3 February, a second logging run was conducted with the third-party Göttingen Borehole Magnetometer tool. The last tool string deployed was the Formation MicroScanner-sonic, which was run between 1335 and $1655 \mathrm{~h}$ and made two passes in the open hole.

The drill string was recovered when logging was concluded, and the end of the pipe cleared the seafloor at $1850 \mathrm{~h}$ on 3 February. Once the drill collars were set back in the derrick, the beacon was recovered, and the drilling equipment was secured, the vessel departed at $2200 \mathrm{~h}$ for the $391 \mathrm{nmi}$ voyage to the final Site U1377 (prospectus Site LOUI-4B) on Hadar Guyot, the youngest seamount targeted during Expedition 330. The total time on Hole U1376A was 191 h, or 8.0 days (Fig. F3).

\section{Sedimentology}

Sediment at Site U1376 was restricted to the sedimentary cover of Burton Guyot, with no sedimentary interbeds occurring in the igneous basement. Two stratigraphic units were defined on the basis of compositional and textural characteristics of the sediment at macroscopic and microscopic scales (Fig. F4):

- Unit I (0-23.45 mbsf; lower boundary = Section 330-U1376A-3R-4, $92 \mathrm{~cm}$ ): younger sedimentary cover of seamount, composed of layered multicolor volcanic sandstone and breccia devoid of bioclasts, with minor occurrences of volcanic tuff. Several ferromanganese crusts were observed in the uppermost part of the sequence. Unit I was divided into four subunits (see below).

- Unit II (23.45-41.93 mbsf; lower boundary = Section 330-U1376A-5R-3, $122 \mathrm{~cm}$ ): older sedimentary cover of seamount, composed of algal boundstone-rudstone and multicolor basalt conglomerate with some shallow-marine bioclasts. Unit II was divided into two subunits (see below).

\section{Unit I}

Interval: Sections 330-U1376A-1R-1, $0 \mathrm{~cm}$, to 3R-4, $92 \mathrm{~cm}$

Depth: 0-23.45 mbsf

Age: Miocene (possibly younger or older; Subunit IA) and between later Cretaceous(?) and Miocene (Subunits IB-ID)

Stratigraphic Unit I represents a younger sedimentary cover that extends between the seafloor and $23.45 \mathrm{mbsf}$. It is composed of several layers of multicolor volcanic breccia; multicolor sandy volcanic breccia; multicolor layered, laminated, or bioturbated volcanic sandstone; and bioturbated brown volcanic tuff. The distinct compositions of the volcaniclastic deposits and sedimentary textures were used to divide Unit I into four subunits (Fig. F4). Estimates of grain size and roundness with depth (see "Sedimentology" in the "Methods" chapter [Expedition 330 Scientists, 2012a]) are illustrated in Figure F4 and provided in a supplementary table (see U1376A.XLS in SIZE in SEDIMENT in "Supplementary material").

\section{Subunit IA}

Interval: Sections 330-U1376A-1R-1, $0 \mathrm{~cm}$, to 1R-2, $7 \mathrm{~cm}$

Depth: 0-1.52 mbsf

Age: Miocene (possibly younger or older)

Stratigraphic Subunit IA extends from the seafloor to 1.52 mbsf (Fig. F4). Its lower boundary is defined by 
an erosional surface and the disappearance of rounded basalt pebbles in underlying Subunit IB (see below). Subunit IA is composed of grain-supported multicolor volcanic breccia with two interbeds of bioturbated brown volcanic sandstone (Fig. F5A). The top of the subunit is capped by a $\sim 3 \mathrm{~cm}$ thick ferromanganese encrustation. Three other ferromanganese encrustations were observed at the interface between the breccia and sandstone at 0.29, 0.43, and 0.76 mbsf. The crusts and sediment infills in burrow holes contain minor amounts of nannofossil-foraminiferal chalk. Nannofossils found between 0.41 and 0.76 mbsf provide a possible Miocene age of deposition for some parts of Subunit IA; the ages of the uppermost $(<0.41 \mathrm{mbsf})$ and lowermost $(>0.76 \mathrm{mbsf})$ Subunit IA are unconstrained and may be younger or older than Miocene, respectively (see "Paleontology"). The volcanic breccia is cemented by calcite and zeolite and has a layered texture. The clasts are composed of abundant sand-size to pebbly grains of basalt and altered volcanic glass. Rare partly fresh olivine-pyroxene aggregates were observed as grains in the breccia or enclaves in some basalt clasts. The largest clasts per $10 \mathrm{~cm}$ interval are composed of basalt cobbles. Average clast roundness ranges between very angular and subangular. Some of the largest basalt grains are rounded to well rounded.

Microscope observations (Sample 330-U1376A-1R-1, 30-33 cm [Thin Section 231]) showed that the brown bioturbated volcanic sandstone is composed of abundant reworked vitric fragments and minor basalt grains. Basalt grains are more abundant toward the base of the sandstone. These observations indicate that the volcanic sandstone layers of Subunit IA likely represent turbidites. Microscope observations of a layer of volcanic breccia (Sample 330U1376A-1R-1, 103-107 cm [Thin Section 232]) indicated that the sediment is mostly composed of a heterogeneous assemblage of basalt grains and altered glass, with some large pyroxene, olivine, plagioclase, and amphibole.

\section{Subunit IB}

Interval: Sections 330-U1376A-1R-2, $7 \mathrm{~cm}$, to 1R-4, $30 \mathrm{~cm}$

Depth: $1.52-4.50 \mathrm{mbsf}$

Age: between later Cretaceous(?) and Miocene

Stratigraphic Subunit IB is $2.98 \mathrm{~m}$ thick and extends from 1.52 to 4.50 mbsf (Fig. F4). Its lower boundary corresponds to the appearance downhole of monolithic layered sandy volcanic breccia and volcanic breccia of Subunit IC (see below). Subunit IB is predominantly composed of heterolithic layered multicolor volcanic breccia, with some laminated brown and gray volcanic sandstone (Fig. F5B). The age of deposition of Subunit IB is indirectly constrained between the later Cretaceous(?) and Miocene on the basis of stratigraphic relationships and paleontological ages obtained in Subunits IA and IIB (see "Paleontology"). The bulk of the sediment of Subunit IB is composed of fragments of basalt and volcanic glass. The largest clast size ranges between coarse sand and pebble, and the average clast roundness is very angular to subangular. Clast size increases uphole throughout Subunit IB (Fig. F4). An interval of volcanic sandstone (Section 330-U1376A-1R-3, 69$100 \mathrm{~cm}$ ) was interpreted as a turbidite on the basis of an erosional surface at the bottom of the interval, normal grading in the lowermost part of the sandstone, and fine laminae in most of the interval.

Thin section observation (Sample 330-U1376A-1R-3, $75-78 \mathrm{~cm}$ [Thin Section 233]) showed that the turbidite in Section 330-U1376A-1R-3 is composed of abundant glass; minor clinopyroxene and feldspar; and rare amphibole, biotite, olivine, and algal fragments. The sediment of Subunit IB is cemented by zeolite and calcite.

\section{Subunit IC}

Interval: Sections 330-U1376A-1R-4, $30 \mathrm{~cm}$, to 3R-3, $21 \mathrm{~cm}$

Depth: 4.50-21.48 mbsf

Age: between later Cretaceous(?) and Miocene

Stratigraphic Subunit IC is $16.98 \mathrm{~m}$ thick and extends from 4.50 to 21.48 mbsf (Fig. F4). Its lower boundary corresponds to the appearance downhole of heterolithic multicolor volcanic breccia in Subunit ID (see below). Similar to Subunit IB above, the age of deposition of Subunit IC is indirectly constrained between the later Cretaceous(?) and Miocene on the basis of stratigraphic relationships and paleontological ages obtained in Subunits IA and IIB (see "Paleontology"). Subunit IC is predominantly composed of monolithic multicolor sandy volcanic breccia and volcanic breccia and rare monolithic multicolor volcanic sandstone (Fig. F5C). The breccia is layered, with a few occurrences of erosional surfaces and cross-bedded structures. The clasts in the breccia are mostly composed of altered fragments of glass and fine-grained (aphyric) basalt. Similar to Subunit IA, partly fresh olivine-pyroxene aggregates were found as grains in the breccia and enclaves in some basalt clasts. The largest clast size is consistent throughout Subunit IC and ranges between granule and pebble, with a small increase and decrease in grain size at the top and bottom, respectively, of the subunit (Fig. F4). The average roundness of the clasts is very angular to subangular.

Microscope observations (Samples 330-U1376A1R-4, 39-42 cm [Thin Section 234]; 2R-4, 33-36 cm 
[Thin Section 235]; and 2R-6, 31-35 cm [Thin Section 236]) showed that the volcaniclastic deposits of Subunit IC are essentially composed of vesiculated altered glass fragments with olivine and fine-grained basalt clasts. Some glass fragments are pumiceous. The basalt clasts occur both as grains in volcaniclastic deposits or, more rarely, as enclaves in larger glass fragments. There is a lack of evidence for reworking of the clasts in the volcaniclastic deposits of Subunit IC.

\section{Subunit ID}

Interval: Sections 330-U1376A-3R-3, $21 \mathrm{~cm}$, to 3R-4, $92 \mathrm{~cm}$

Depth: 21.48-23.45 mbsf

Age: between later Cretaceous(?) and Miocene

Stratigraphic Subunit ID is $1.97 \mathrm{~m}$ thick and extends from 21.48 to 23.45 mbsf (Fig. F4). Although not recovered, its lower boundary is defined by the appearance of carbonate sediment in underlying Unit II (see below). The deposition age of Subunit ID is constrained between the later Cretaceous(?) and Miocene on the basis of stratigraphic relationships and paleontological ages obtained in Subunits IA and IIB (see "Paleontology"). Subunit ID is composed of heterolithic multicolor volcanic breccia with a few bioclasts and monolithic brown coarse tuff (Fig. F5D). These volcaniclastic deposits are normally graded (volcanic breccia) or layered and bioturbated (coarse tuff). Compaction structures (load casts and a synsedimentary fault) were observed at the interfaces between the tuff and breccia (Points 1 and 2 in Fig. F5D). The maximum clast size of the breccia ranges between very coarse sand and pebble, with very angular to subangular grain roundness.

Microscope observations (Sample 330-U1376A-3R-3, $81-84 \mathrm{~cm}$ [Thin Section 237]) indicated that the volcanic breccia is cemented by calcite and zeolite. Bioclasts in this sediment are mostly composed of red algae. A sample of coarse tuff (Sample 330-U1376A3R-3, 113-117 cm [Thin Section 238]) is composed of vesiculated partly pumiceous glass fragments with a pristine texture suggestive of a volcanic (pyroclastic) origin.

\section{Unit II}

Interval: Sections 330-U1376A-3R-4, $92 \mathrm{~cm}$, to $5 \mathrm{R}-3,122 \mathrm{~cm}$

Depth: 23.45-41.93 mbsf

Age: between later Cretaceous(?) and Miocene (Subunit IIA) and later Cretaceous(?) (Subunit IIB)

Stratigraphic Unit II is an $18.48 \mathrm{~m}$ thick older sedimentary cover that extends between 23.45 and 41.93 mbsf on top of the volcanic basement of Burton Guyot. Occurrences of white algal limestone and dark gray basalt conglomerate allowed this unit to be divided into two subunits (Fig. F4).

\section{Subunit IIA}

Interval: Sections 330-U1376A-3R-4, $92 \mathrm{~cm}$, to $5 \mathrm{R}-1,40 \mathrm{~cm}$

Depth: 23.45-38.60 mbsf

Age: between later Cretaceous(?) and Miocene

Stratigraphic Subunit IIA is $15.15 \mathrm{~m}$ thick and extends from 23.45 to 38.60 mbsf (Fig. F4). Its lower boundary is defined by the occurrence of dark gray basalt conglomerate in underlying Subunit IIB (see below). The age of deposition of Subunit IIA is constrained between the later Cretaceous(?) and Miocene on the basis of stratigraphic relationships and paleontological data from Subunits IA and IIB (see "Paleontology"). Subunit IIA is mainly composed of white coralline algal boundstone with some minor white algal rudstone (Fig. F5E, F5F). The composition of the limestone evolves downhole from pure white carbonate sediment devoid of volcanic grains at the top to yellowish-red carbonate sediment with a few basalt clasts at the base. This compositional pattern defines a transition to the basalt conglomerate with bioclasts of underlying Subunit IIB. The largest basalt clasts of the lower part of Subunit IIA range in size from coarse sand to pebble, with a gradual increase in size toward the base of Subunit IIA (Fig. F4). The average basalt clast roundness is angular to well rounded.

The bulk of the limestone of Subunit IIA (boundstone) represents a biogenic framework related to in situ growth of algae. Encrusting forms of algae were found throughout the subunit (Fig. F5F), whereas branching forms of algae predominantly occur in the upper part (in intervals devoid of volcanic clasts) (Fig. F5E). The boundstone also includes some minor bryozoans, annelids, and encrusting bivalves (e.g., oysters). Minor amounts of nonencrusting bivalves, gastropods, echinoderms, solitary coral, and basalt clasts predominantly occur in the rudstone that represents moderately reworked bioclast-rich limestone. Bivalve boreholes and dissolution features in the algal framework, fossil-bearing micrite, and shell fragments are frequent in Subunit IIA. Dissolution voids are often partly or entirely filled with fossil-barren micrite (Fig. F6A). This micrite probably consists of vadose silt, which indicates a subtidal to intertidal environment of cementation (Flügel, 1982).

Similarly, frequent dissolution features and cementation patterns suggestive of a vadose environment were also observed in thin section (Samples 330U1376A-3R-4, 129-133 cm [Thin Section 239]; 3R-5, 
99-103 cm [Thin Section 240]; 4R-1, 45-49 cm [Thin Section 241]; 4R-2, 55-58 cm [Thin Section 242]; and 4R-3, 65-68 cm [Thin Section 243]) (Fig. F6B).

\section{Subunit IIB}

Interval: Sections 330-U1376A-5R-1, $40 \mathrm{~cm}$, to 5R-3, $122 \mathrm{~cm}$

Depth: 38.60-41.93 mbsf

Age: later Cretaceous(?)

Stratigraphic Subunit IIB is $3.33 \mathrm{~m}$ thick and extends from 38.60 to $41.93 \mathrm{mbsf}$ (Fig. F4). Its lower boundary corresponds to an erosional surface that marks the transition downhole to the volcanic basement of Burton Guyot (see "Igneous petrology and volcanology"). A later Cretaceous(?) age of deposition of Subunit IIB is constrained by the occurrence of possible rudist fossils (see "Paleontology"). Subunit IIB is composed of a dark gray basalt conglomerate with a few shallow-marine bioclasts (e.g., red algae, annelids, and bivalves) (Fig. F5G, F5H). Three erosional surfaces were recognized in the subunit at 39.74, 41.07 , and 41.88 mbsf. The largest grain size ranges between very coarse sand and boulder, and the average grain roundness is very angular to well rounded.

Microscope observations (Samples 330-U1376A-5R1, 65-67 cm [Thin Section 244], and 5R-2, 80-83 cm [Thin Section 245]) indicated that the basalt conglomerate is predominantly composed of fragments of fine-grained basalt and algae, with a minor amount of bryozoans, bivalves, annelids, echinoderms, shell fragments, and clinopyroxene. In Thin Section 244, interstitial spaces of the conglomerate include dogtooth cement and geopetal structures defined by vadose silt and sparry calcite cement (Fig. F6C). These features are indicative of a vadose environment of cementation (Flügel, 1982). Two generations of calcite cement (fibrous and granular) were recognized in Thin Section 245 (Fig. F6D). These observations are indicative of a shallow-marine subtidal to intertidal environment of deposition for Subunit IIB.

\section{Interpretation of sediment and volcaniclastic deposits at Site U1376}

Units I and II at Site U1376 represent the sedimentary cover of Burton Guyot, which probably was deposited after erosional flattening of the drilled volcanic edifice. Unit I is interpreted to have been deposited in a hemipelagic or pelagic environment. The ferromanganese encrustations of Subunit IA suggest a lower sedimentation rate in the uppermost part of the drilled sequence. The chalk included in the ferromanganese crusts or burrows of Subunit IA contains nannofossils with a middle Miocene to late
Miocene age (see "Paleontology"). These ages may correspond to the age of sediment deposition or postdepositional percolation of fine-grained sediment in cracks or voids. Occurrences in Subunits IA and IB of turbidites and layered volcanic breccia that possibly represent hyperconcentrated flow deposits (Smith and Lowe, 1991) document the existence of highly dynamic depositional processes on top of Burton Guyot. The $16.98 \mathrm{~m}$ thick monolithic layered deposits of Subunit IC are interpreted to represent volcanic products formed during the later Cretaceous and Miocene. These deposits were possibly emplaced during a rejuvenated volcanic stage of Burton Guyot (see "Igneous petrology and volcanology"). Subunit ID, which is composed of layered heterolithic volcanic breccia and coarse tuff, is interpreted to consist of turbidites, hyperconcentrated flow deposits, and volcanic deposits emplaced in a hemipelagic environment. Similar to deposits of Subunit IC above, the tuffs of Subunit ID also record a possible rejuvenated volcanic stage of Burton Guyot between the later Cretaceous and Miocene.

Unit II is interpreted as a transgression sequence deposited on top of Burton Guyot in the later Cretaceous (see "Paleontology") and possibly younger times. The composition, grain roundness, and cement textures of Unit II suggest deposition in a highenergy environment in the zone of wave influence, with possibly frequent emergence events. These observations and the deposition of Unit I in a hemipelagic to pelagic setting suggest that the Unit II-I transition likely reflects subsidence of the drilled seamount. Boundstone and rudstone of Subunit IIA record the formation of a $15.15 \mathrm{~m}$ thick algal reef that developed (under very shallow marine conditions) probably shortly after flattening of the drilled seamount by erosional processes. Subunit IIB, which is composed of basalt conglomerate, is interpreted to have been deposited in a shallow-marine subtidal to intertidal environment on the basis of basalt clast roundness, the occurrence of shallow-marine bioclasts, and cement textures. The erosional surface recognized at the base of this subunit ( 41.93 mbsf) corresponds to the boundary between the sedimentary cover and volcanic basement at Site U1376. Possibly, this boundary reflects a major erosional event associated with the flattening of Burton Guyot.

\section{Paleontology}

Subsea camera observation during the spotting of Hole U1376A indicated that no apparent soft sediment was present in the immediate area of Hole U1376A on Burton Guyot. Rotary coring therefore retrieved only the consolidated sequences of strati- 
graphic Units I-IV. Volcaniclastic rock fragments from Cores 330-U1376A-1R and 2R of Subunit IC and limestone from Cores $3 \mathrm{R}$ and $4 \mathrm{R}$ of Subunit IIA were taken for microfossil analyses. Thin sections taken from Subunit IIA and the basaltic conglomerate of Subunit IIB were also used for planktonic foraminiferal biostratigraphy. Nannofossil biostratigraphy was supplemented by additional powdered samples from Cores 1R (Subunit IA) and 4R (Subunit IIA), yielding a preliminary age for the upper portion of Subunit IA of middle to late Miocene (Fig. F7; Table T2).

Additionally, macrofossils were found in Subunits IIA and IIB. Partial dissolution prevented taxonomic analyses of most of the macrofossils, but some preserved specimens occur locally, allowing a possible later Cretaceous age assignment for Subunit IIB, as discussed in "Macrofossils."

\section{Calcareous nannofossils}

Calcareous nannofossil content was analyzed in nine samples from Hole U1376A. Six of the nine samples proved to be barren. Three of these were taken from the consolidated sediments in core catchers, including Samples 330-U1376A-1R-7-PAL (Subunit IC), 2R6-PAL (Subunit IC), and 3R-6-PAL (Subunit IIA). The other three barren samples were taken (by scraping the rocks with a razor blade) from the limestone of Subunit IIA from Sections 330-U1376A-4R-1, $1 \mathrm{~cm}$; $4 \mathrm{R}-4,88 \mathrm{~cm}$; and 4R-4, $107 \mathrm{~cm}$.

The samples containing nannofossils were taken from Section 330-U1376A-1R-1 at $1 \mathrm{~cm}, 41 \mathrm{~cm}$, and $76 \mathrm{~cm}$, in Subunit IA. These discrete samples are composed of white chalk situated either directly above or below and in contact with a ferromanganese crust (Fig. F4), and they are isolated from each other by the volcanic sandstone/breccia material of Subunit IA (see "Sedimentology"). These observations suggest nannofossil assemblages in the chalk are free of any contaminating influence; nonconcurrent ranges observed in some chalk samples are best explained by their occurrence in condensed intervals, as clearly indicated by their association with the ferromanganese crusts. Sample 1R-1, $76 \mathrm{~cm}$, contains Cyclicargolithus abisectus (Zones CP19-CN1a; late Oligocene-early Miocene) and discoasters such as Discoaster exilis (late early to early middle Miocene). Several examples of Triquetrorhabdulus rugosus place this sample at least in Zone CN4, and clear examples of Discoaster moorei co-occurring with likely specimens of Discoaster kugleri led to a preliminary minimum age assignment of Subzone CN5b (between middle and late Miocene).

Sample 330-U1376A-1R-1, $41 \mathrm{~cm}$, in Subunit IA has slightly worse preservation, notably shown by in- creased overgrowth of discoasters. The Neogene background species Calcidiscus leptoporus is one of the most readily identifiable species present. This species occurs along with Discoaster asymmetricus, which is placed as low as Subzone CN8b by PerchNielsen (1985). This sample is assigned to Subzone $\mathrm{CN} 9 \mathrm{~b}$ (late Miocene) on the basis of unambiguous examples of Amaurolithus primus and the occurrence of Amaurolithus tricorniculatus.

The state of preservation in Sample 330-U1376A-1R$1,1 \mathrm{~cm}$, at the top of Subunit IA is very poor, and no zonal assignment is currently given. However, it is thought to be at least as young as (or most probably younger than) Sample 1R-1, $41 \mathrm{~cm}$. Further shorebased research should allow for biostratigraphic refinement of these samples and age assignments.

\section{Planktonic foraminifers}

Only Samples 330-U1376A-1R-7, 49-50 cm (8.96 mbsf), and 2R-6, 121-122 cm (17.47 mbsf), from the consolidated volcanic sandstone of Subunit IC and Samples 3R-6, 117-120 cm (26.73 mbsf), and 4R-4, $36-39 \mathrm{~cm}$ (33.23 mbsf), from the consolidated limestone of Subunit IIA were used for planktonic foraminiferal biostratigraphy (Table T3). However, none of these samples contain planktonic foraminifers, making age estimation of these units impossible. In addition to these samples, four thin sections taken from Subunit IIA limestone and three thin sections taken from Subunit IIB basaltic conglomerate were examined (Table T4), but these were also barren (or had only scarce occurrences) of planktonic foraminifers. The Subunit IIA limestone is mainly composed of in situ calcareous algal framework and micrite grains containing macrofossil fragments such as bivalves, bryozoans, and echinoderms (see "Sedimentology"). Although Sample 3R-5, 99-103 cm (25.05 mbsf), contains one globular planktonic foraminifer, no other sample recovered from Subunit IIA contains any planktonic foraminifers. The Subunit IIB conglomerate consists of volcaniclastics and bioclasts, including annelids, bivalves, bryozoans, calcareous algae, echinoderms, and gastropods, which is indicative of a rocky shore environment (see "Sedimentology"). Sample 5R-1, 65-67 cm (38.85 mbsf), contains one planktonic foraminifer, but no planktonic foraminifers were found in the other thin sections from Subunit IIB. Because of the scarce occurrence of planktonic foraminifers, a planktonic foraminiferal zonal definition could not be made for Hole U1376A.

\section{Macrofossils}

The Subunit IIA limestone contains many molluscan fossils, of which most shell materials have been dis- 
solved. However, Samples 330-U1376A-5R-3, 94-100 $\mathrm{cm}$ (41.65 mbsf), and 5R-3, 101-106 cm (41.72 mbsf), of Subunit IIB contain relatively well preserved molluscan fossils, possibly identifiable as later Cretaceous rudists. These fossils have centimetersized round shells composed of two shell layers (Fig. F8). Although their inner shell layers were dissolved, creating space between the sandstone infill and the outer shell layer, the outer shell layers are typically well preserved, which implies that the inner and outer shell layers were originally composed of aragonite and calcite, respectively. An outer surface of the inner shell layer of the specimen obtained from Sample $5 \mathrm{R}-3,101-106 \mathrm{~cm}$, shows fine striations and undulations indicative of an accretionary growth pattern (Fig. F9). However, key morphological characteristics for final identification of the taxonomy of these molluscan fossils (such as three-dimensional morphology and shell microstructures) await detailed postexpedition analyses using whole-round computed tomography scanning.

\section{Igneous petrology and volcanology}

In Hole U1376A, 140.9 m of igneous rock was penetrated after igneous basement was entered at 41.93 mbsf. The igneous sequence was divided into 42 lithologic units, which have been grouped into two stratigraphic units (Fig. F10). To help achieve the paleomagnetic objectives of this expedition, each of the more massive igneous lithologic units was assigned an in situ confidence index (ISCI) following the procedures described in "Igneous petrology and volcanology" in the "Methods" chapter (Expedition 330 Scientists, 2012a). The lithologic units and their ISCI values are summarized in Table T5. In this section we first describe the volcanic components of the sedimentary units, then describe each of the igneous units, and finally interpret the entire igneous succession.

\section{Stratigraphic sedimentary units}

\section{Unit I (volcanic sandstone and breccia)}

Unit I comprises four subunits of volcanic sandstone and breccia (see "Sedimentology"), representing the products of a phase of volcanism that postdates the erosion and submergence of Burton Guyot. These deposits are separated from earlier volcanic rocks by a $15 \mathrm{~m}$ thick unit (Subunit IIA) of white algal limestone (see "Sedimentology"). Clasts from Unit I breccia provide us with the only material from a posterosional or rejuvenation phase of magmatism recovered during Expedition 330. Unit I is mostly composed of fragments of basalt (Fig. F11), but some layers are dominated by angular fragments of glass with subordinate grains of plagioclase, augite, altered olivine, hornblende, and rare biotite (see "Sedimentology"). Basaltic clasts in Thin Section 234 (Sample 330-U1376A-1R-4, 39-42 cm) from Subunit IC contain anhedral crystals of orthopyroxene surrounded by coronas composed of tiny clinopyroxene crystals (Fig. F12). The orthopyroxene crystals are most likely xenocrysts derived from disrupted mantle xenoliths. Small (up to $15 \mathrm{~mm}$ ) aggregates of olivine and pyroxene, which may in fact be intact mantle xenoliths, were noted in Subunits IA and IC.

\section{Basaltic clasts in sedimentary Subunit IIB}

The larger basaltic clasts within the conglomerate of Subunit IIB (see "Sedimentology") were divided into four types on the basis of their appearance in hand specimen. Each clast type is described below:

- Type 1: sparsely olivine-phyric basalt that is medium gray, with $1.5 \%$ olivine phenocrysts (altered to iddingsite and carbonate; maximum size $=4 \mathrm{~mm}$, modal size $=2 \mathrm{~mm})$. The groundmass is aphanitic, with $0.5 \%$ vesicles (elongate, subangular; $100 \%$ filled with carbonate and green clay) and veins (filled with green clay and carbonate).

- Type 2: highly olivine-phyric basalt that is brownish gray, with $10 \%$ olivine phenocrysts (slightly altered to iddingsite and carbonate; maximum size $=7 \mathrm{~mm}$, modal size $=2 \mathrm{~mm}$ ) and small amounts of native copper. The groundmass is fine grained, with $6 \%$ vesicles (low sphericity, angular; filled with carbonate) and veins (filled with carbonate).

- Type 3: moderately olivine-phyric basalt that is reddish gray, with $2 \%$ olivine phenocrysts (moderately altered to green clay, carbonate, and iddingsite; maximum size $=2 \mathrm{~mm}$, modal size $=1.5 \mathrm{~mm}$ ). The groundmass is fine grained, with $1 \%$ vesicles (moderate sphericity to elongate, rounded; filled with carbonate and green clay) and veins (filled with carbonate).Type 4: aphyric basalt that is reddish gray, with no phenocrysts. The groundmass is fine grained, with 10\%-30\% vesicles (low to elongate sphericity, subrounded [3\% filled]; blue coating) and veins (filled with carbonate).

\section{Lithologic and stratigraphic igneous units}

\section{Unit III}

Interval: Sections 330-U1376A-5R-3, $122 \mathrm{~cm}$, to $14 \mathrm{R}-4,47 \mathrm{~cm}$

Depth: 41.93-110.14 mbsf 
Lithology: moderately to highly olivine-augitephyric basalt and basalt breccia

Lithologic units: $1-17$

Unit III is the uppermost stratigraphic unit in the igneous basement and was encountered at $41.93 \mathrm{mbsf}$, where the sedimentary conglomerate of Subunit IIB sits unconformably on its inclined, eroded, upper surface. Unit III was defined on the basis of its dominant olivine-augite phenocryst assemblage. The uppermost three lithologic units form a distinctive $4.82 \mathrm{~m}$ thick interval composed mostly of moderately to highly olivine-augite-phyric hyaloclastite basalt breccia with a central interval of massive basalt (lithologic Unit 2), which we interpret as a pillow or lobate lava flow. The breccia units contain abundant unaltered glass and clasts of altered basalt. Lithologic Unit 3 is heterolithic breccia containing, in addition to olivine-augite-phyric basalt clasts, some clasts in which augite is absent from the phenocryst assemblage. This interval grades into a $25.46 \mathrm{~m}$ thick interval of moderately olivine-augite-phyric massive basalt units separated by thin units of hyaloclastite breccia (lithologic Units 4-14). Lithologic Units 4-6 comprise rounded or lobate bodies of basalt that have chilled margins and are surrounded by thin zones of red clay containing spalled chips of altered glass (Fig. F13). These bodies of basalt are interpreted as pillows, most of which appear to be in situ. Lithologic Unit 5 is a $1.1 \mathrm{~m}$ thick pillow or lobate lava flow. Lithologic Units 7-14 are composed of breccia with intervals of massive basalt that may be lobate flows, pillows, or large pillow fragments. Lithologic Units 8,10, and 12 are thin lobate flows or large fragments of olivine-phyric basalt. Olivine phenocrysts seen in Thin Section 253 (Sample 330-U1376A-6R$6 \mathrm{~W}, 128-131 \mathrm{~cm}$ ) from lithologic Unit 12 have abundant small glassy inclusions $(<50 \mu \mathrm{m}$ in diameter), some containing shrinkage bubbles (Fig. F14). The pillows become increasingly fragmented downhole through lithologic Units 13 and 14, and the proportion and size of basaltic clasts then increase until the basalt becomes entirely massive in lithologic Unit 15. The lower part of lithologic Unit 14 is probably, therefore, the brecciated flow top of lithologic Unit 15.

Lithologic Unit 15 is a $33.11 \mathrm{~m}$ thick massive lava flow composed of highly olivine-augite-phyric basalt that is remarkably uniform throughout. It has $10 \%$ unaltered olivine phenocrysts as large as $10 \mathrm{~mm}$ and $4 \%$ augite phenocrysts as large as $8 \mathrm{~mm}$ (Fig. F15). The lowest $29 \mathrm{~cm}$ of this lava flow is fractured, and one of the fractures is filled with hyaloclastite breccia from underlying lithologic Unit 16, whereas hyaloclastite in the uppermost $30 \mathrm{~cm}$ of lithologic Unit 16 is baked and noticeably darker than that below
(Fig. F16A). The baked layer has a much higher magnetic susceptibility than either the overlying lava flow or the underlying hyaloclastite (see "Physical properties" and "Paleomagnetism"). Lithologic Unit 16 does not contain pillows but has small angular clasts similar to those in the breccia intervals above the $\sim 33 \mathrm{~m}$ thick lava flow (lithologic Unit 15). Many of these clasts are augite-free and may have been derived from Unit IV. Unit III ends with a $2.07 \mathrm{~m}$ thick highly olivine-augite-phyric basalt lava flow (lithologic Unit 17) that contains 10\% unaltered olivine and $2 \%$ augite phenocrysts.

\section{Unit IV}

Interval: Sections 330-U1376A-14R-4, $47 \mathrm{~cm}$, to 23R-6, $75 \mathrm{~cm}$

Depth: 110.14-180.32 mbsf

Lithology: moderately to highly olivine-phyric basalt and breccia with aphyric basalt

Lithologic units: $18-42$

Unit IV is distinguished from Unit III by the disappearance of augite phenocrysts and is dominated by moderately to highly olivine-phyric basalt breccia. An $8 \mathrm{~cm}$ thick interval of aphyric basalt separates the highly olivine-augite-phyric lava flow at the bottom of Unit III from the moderately olivine-phyric breccia of Unit IV. The thin interval of aphyric basalt (lithologic Unit 18) is interpreted as a fragment of basalt derived from the first of two intrusive bodies that we interpret as dikes (see "Intrusive sheets"). The top of Unit IV is interpreted to represent an erosional contact, as discussed in "Interpretation of the igneous succession at Site U1376."

The Unit IV breccia commonly has a hyaloclastite matrix with moderately altered to unaltered glass shards and abundant large (up to $30 \mathrm{~cm}$ ) olivinephyric basalt clasts (Fig. F17). There is no clear evidence that any of these clasts are in situ pillows, although they commonly have glassy margins and may be pillow fragments. The lower $2.6 \mathrm{~m}$ of the $17.35 \mathrm{~m}$ thick interval of hyaloclastite breccia at the top of Unit IV (lithologic Units 19 and 21) is composed of exceptionally fresh basaltic glass shards cemented by only a thin film of clay minerals (Fig. F18). The poorly recovered interval from Sections 330-U1376A-17R-4, $44 \mathrm{~cm}$, to 19R-1, $0 \mathrm{~cm}$ (130.00$144.40 \mathrm{mbsf})$, marks a downhole change in the breccia clasts from monolithic to heterolithic. Breccia forming lithologic Units 26, 30, 34, and 36 (134.80$166.50 \mathrm{mbsf})$ contains five different clast types, in contrast to other breccia units. These clast types were distinguished by their phenocryst assemblage and vesicularity. Types 1 and 4 are composed, respectively, of nonvesicular and highly vesicular (20\%) highly olivine-phyric basalt that has a similar pheno- 
cryst content to the hyaloclastite matrix. Types 2 and 3 are composed of nonvesicular and highly vesicular (10\%-20\%) aphyric basalt, respectively. Type 5 , restricted to one occurrence in lithologic Unit 36, is represented by a single moderately augiteolivine-phyric basalt clast-one of only two occurrences of augite phenocrysts in Unit IV, the second being in lithologic Unit 42, the lowermost unit recovered at this site. The first occurrence of heterolithic breccia was observed in Core 330-U1376A-18R in lithologic Unit 26, which had by far the poorest recovery (11\%) of all cores at this site. The recovered material consists of 15 separate $2-14 \mathrm{~cm}$ fragments and a large number of smaller fragments of highly vesicular basalt, some of which are yellowish or red and oxidized. Downhole logging (see "Downhole logging") shows that the unrecovered intervals in Cores $17 \mathrm{R}$ and $18 \mathrm{R}$ are occupied mostly by breccia. This interval was left uncolored in the stratigraphic column (Fig. F10) because clast types could not be determined through macroscopic examination.

The $40 \mathrm{~m}$ interval from Sections 330-U1376A-17R2, $93 \mathrm{~cm}$, to 22R-3, $82 \mathrm{~cm}$ (lithologic Units 22-37; 127.57-167.23 mbsf), which includes intervals of heterolithic breccia, also contains six aphyric basalt bodies (lithologic Units 22, 24, 27, 31, 35, and 37) as thick as $1.6 \mathrm{~m}$. These basalt bodies are highly vesicular (5\%-15\%) and are interpreted as lobate flows or lava fragments. Lithologic Unit 29 is a $1.79 \mathrm{~m}$ thick massive basalt flow that contains no vesicles and varies from aphyric to highly olivine-phyric (0\%-30\% olivine phenocrysts) over intervals of $25 \mathrm{~cm}$. Olivine phenocrysts are concentrated toward the base of the flow, although there are aphyric intervals in its center. Two other olivine-phyric basalt bodies are fragmented (lithologic Unit 33) or thin (lithologic Unit 39) and lack clear evidence to determine whether they are larger clasts within the breccia or lobate flows.

Drilling ended at $182.8 \mathrm{mbsf}$ in the $0.56 \mathrm{~m}$ thick lithologic Unit 42, which consists of isolated fragments of moderately olivine-augite-phyric basalt, some with adhering breccia selvages.

\section{Intrusive sheets}

Lithologic Units 18, 20, and 41 in Unit IV are parts of intrusive sheets composed of fine-grained aphyric basalt. The $8 \mathrm{~cm}$ thick lithologic Unit 18 sits between stratigraphic Units III and IV and is highly fractured, making its contacts difficult to observe and interpret (Fig. F16D). It contains thin trains of very small vesicles and closely resembles the chilled margin of another intrusive sheet $1.78 \mathrm{~m}$ downhole (lithologic Unit 20). These vesicle trains are truncated upward at the base of lithologic Unit 17, a $2.07 \mathrm{~m}$ thick basalt lava flow that defines the bottom of Unit III, and downward at what looks like the broken lower edge of lithologic Unit 18. It seems likely, therefore, that lithologic Unit 18 is a detached fragment of lithologic Unit 20, which was exposed nearby at an erosional surface at the top of Unit IV. If so, the boundary between Units III and IV could represent a significant time gap between eruptive phases. The $1.78 \mathrm{~m}$ interval of breccia that separates lithologic Units 18 and 20 contains two intervals (330U1376A-15R-1, 8-15 cm, and 15R-1, 79-87 cm) that are partly occupied by the margin of an aphyric basalt intrusion. The chilled margin of lithologic Unit 20 runs parallel to the edge of the core and is brecciated in places (Fig. F19). Vesicle trains run parallel to the sheet margins and are aligned vertically in the center of the sheet. This suggests that the sheet is near vertical and is therefore a dike.

Lithologic Unit 41 is very similar in appearance to lithologic Unit 20 and has a steeply dipping upper contact with a well-preserved glassy margin. The lower contact was not recovered. Bands of vesicles run vertically through the unit and parallel to the margins, which wrap around clasts within the breccia. This unit is heavily fractured in places, with vertical veins (see "Structural geology") that may be the result of contraction during cooling. All of these features suggest that this sheet is also a dike.

\section{Interpretation of the igneous succession at Site U1376}

The basement section cored at Site U1376 on Burton Guyot comprises a succession of basaltic breccia, pillow lava, and massive lava flows. Two units were defined on the basis of phenocryst phases, with Unit IV mostly containing olivine phenocrysts and Unit III containing both olivine and augite phenocrysts. The deepest unit cored (lithologic Unit 42) is breccia with clasts containing both olivine and augite phenocrysts. This unit may be the top part of a third stratigraphic unit; however, given the very short interval $(0.56 \mathrm{~m})$ occupied by this unit, it is included in stratigraphic Unit IV.

The bottom $13.1 \mathrm{~m}$ of the succession comprises mostly olivine-phyric basalt breccia. An interval of highly vesicular aphyric basalt (166.5-167.2 mbsf) overlying this breccia heralds the arrival of a second aphyric magma type. The next $31.7 \mathrm{~m}$ of the succession comprises heterolithic breccia with olivine-phyric and aphyric basalt clasts and thin flows of aphyric basalt. This interval records a period when two types of magma were being erupted in the area at the same time. Lithologic Unit 26, the upper unit in this interval, consists of a number of highly vesicular and oxidized fragments of aphyric and olivine- 
phyric basalt and may provide evidence for a period of shallow-water or subaerial volcanism. It may be significant that this unit lies in the middle of a $12 \mathrm{~m}$ interval of very low core recovery (11\% in Core 330 U1376A-18R) that may be occupied by friable and poorly cemented breccia, consistent with the results of downhole logging (see "Downhole logging"). Two thin flows of aphyric basalt separated by a 24 $\mathrm{cm}$ thick interval of olivine-phyric basalt breccia (lithologic Units 22-24) mark the last occurrence of aphyric basalt in the eruptive succession. The upper $17.35 \mathrm{~m}$ interval of Unit IV (lithologic Units 21 and 19 ) is composed of olivine-phyric hyaloclastite breccia containing a high proportion of unaltered glass.

Unit III records a change in magma composition from one crystallizing olivine to a slightly more evolved one crystallizing olivine and augite. The first significant appearance of olivine-augite-phyric basalt is marked by two massive lava flows, 2.07 and $33.11 \mathrm{~m}$ thick, respectively, separated by a $2.75 \mathrm{~m}$ interval of basalt breccia. The remainder of Unit III is composed of olivine-augite-phyric basalt breccia and pillow lava, except for three short intervals of olivine-phyric basalt in Core 330-U1376A-6R (Fig. F10). The presence of pillow lava high in the Unit III succession suggests that most, if not all, of the basement section was erupted in a marine environment.

Intrusive sheets (dikes) cut the whole of Unit IV and therefore postdate the emplacement of this unit. Although these dikes were not seen in Unit III, they may have extended through it and, if so, would represent the last magmatic event recorded in the basement section of Burton Guyot. However, the contact relations of the uppermost dike (lithologic Units 18 and 20) with the overlying olivine-augite-phyric lava flow (lithologic Unit 17) provide evidence for an erosional surface between Units III and IV, implying that the dikes were intruded before the emplacement of Unit III and then were exposed by erosion. There are no aphyric basalt units in Unit III, immediately above the upper observed limit of the dikes, and therefore these dikes cannot be linked directly to any of the recovered volcanic units. It is possible that the dikes fed lava flows stratigraphically above Unit III that have not been preserved. Alternatively, they may have fed aphyric lava flows similar to those in Unit IV, which were removed by erosion before the emplacement of Unit III. Postexpedition studies may be able to address this question.

A record of a posterosional or rejuvenation phase of magmatism at Site U1376 is provided by the volcanic sandstone and breccia of sedimentary Unit I. The composition of clasts in Unit I implies at least two magma types. First, some of the sandstone layers contain fragments of hornblende and biotite, sug- gesting late-stage eruption of more evolved magma than that represented by the basement succession. Second, Subunit IC contains olivine-pyroxene aggregates that may be mantle xenoliths, as supported by the occurrence of partly resorbed orthopyroxene xenocrysts in basalt clasts in Subunit IC.

The presence of olivine and augite phenocrysts in the basaltic basement section at Site U1376 and the complete absence of plagioclase phenocrysts suggest that the magmas were alkaline and more basic than those represented by most of the volcanic rocks drilled at Sites U1372, U1373, and U1374. Reaction coronas around orthopyroxene xenocrysts in basaltic clasts in sedimentary Unit I suggest that the rejuvenation stage magmas were strongly alkaline.

\section{Alteration petrology}

Four stratigraphic units were identified at Site U1376. The sequence includes two sedimentary units and two units of volcanic breccia and lava flows (see "Igneous petrology and volcanology"). The entire section of basaltic rock has undergone some degree of alteration by low-temperature waterrock interactions or weathering, but large intervals are only slightly altered. Lithologies from Hole U1376A are relatively well preserved compared to those at all other Expedition 330 sites.

Overall alteration of the volcanic rocks from Hole U1376A ranges from fresh to complete $(2 \%-95 \%$; Fig. F20), as estimated from core descriptions and thin section observations. Alteration at Site U1376 has resulted in replacement of olivine and volcanic glass in some of the rocks. In contrast, augite is generally well preserved as phenocrysts and in the groundmass throughout the igneous portion of the core. Olivine is altered to iddingsite and hematite only in an interval from 55 to 70 mbsf (Unit III) and even here the transformation is sporadic. Throughout the hole, olivine is either unaltered $(<2 \%$ alteration; 72-106 mbsf) or moderately to completely altered to green clay and calcite (Fig. F21). Fresh olivine is especially abundant in the massive moderately olivine-augite-phyric basalt of Unit III (lithologic Unit 15; Fig. F10; Table T6).

\section{Alteration phases}

We distinguished three main groups of alteration minerals in Hole U1376A:

1. Clay minerals (e.g., smectite, saponite, nontronite, and illite) and celadonite are abundant and were identified using optical microscopy and Xray diffraction spectroscopy (XRD).

2. Carbonates are also abundant secondary minerals as infillings in vesicles and veins. XRD 
analyses of whole rocks, veins, and vesicles suggest a predominance of $\mathrm{Mg}$ calcite, with evidence also of aragonite, siderite, and ankerite (Figs. F22, F23). Aragonite was identified in one interval of highly to completely altered basalt (Sample 330U1376A-6R-1, 96-98 cm).

3 . Other secondary phases are minor zeolites, probably phillipsite, various Fe oxyhydroxides, probably hematite, and goethite. Pyrite is rare but was observed in some fractures (Section 330-U1376A19R-2).

\section{Overall alteration characteristics}

Overall alteration of groundmass ranges from $5 \%$ to $95 \%$, as estimated from visual inspection (Fig. F20). However, alteration in most of the core is slight to moderate. Relatively fresh basalt ( $<20 \%$ alteration) is present throughout the core but is particularly abundant in Unit III. Units below the massive, moderately olivine-augite-phyric basalt (lithologic Unit 15 of stratigraphic Unit III) are mainly composed of volcanic breccia and hyaloclastites, and even those that are moderately altered tend to contain significant amounts of unaltered glass fragments.

On the basis of core descriptions and thin section observations we defined two general alteration groups of basalt: slightly altered gray basalt and more highly altered greenish basalt. Only minor amounts of reddish-brown alteration are present in restricted locations of the core. Representative logs displaying the distribution of alteration colors with depth are given in Figures F20 and F24.

\section{Gray basalt}

Slightly altered gray basalt occurs throughout the core. The groundmass of the gray basalt is slightly altered to fine-grained brown and green minerals difficult to identify in thin section, referred to simply as clay minerals (Fig. F25E). Pyroxene is relatively fresh in this basalt. Olivine is often unaltered, but some grains show partial replacement by green clay and carbonates (Figs. F21, F25A-F25D; Table T6). Fresh glass is present in several sections (discussed below).

\section{Grayish-brown/reddish-brown alteration}

Reddish-brown alteration is limited to very localized portions of the core (Fig. F20) and usually forms zones $<20 \mathrm{~cm}$ wide between clasts. This alteration is characterized by hematite, carbonates, saponite, and perhaps bannisterite (Fig. F22). Large $(>1 \mathrm{~cm})$ prismatic carbonate crystals (Fig. F22) were determined to be aragonite.

\section{Basalt with greenish alteration}

Basalt with greenish alteration is present throughout the core and is the characteristic type of alteration at
Site U1376. Clay minerals (saponite, nontronite, and montmorillonite) are the dominant alteration minerals of the groundmass and appear to be most abundant in the upper part of the basement (42-70 mbsf) and in an interval from 144 to 150 mbsf (Fig. F20). The degree of alteration varies in rocks lower in the basement, but fragments of fresh glass are generally still present.

\section{Vesicle infillings}

Most of the basaltic flows and clasts from Hole U1376A have low vesicularity. Vesicle abundance varies from $0.5 \%$ to $25 \%$, with the high percentages being very rare and found mainly in clasts in volcanic breccia (see "Igneous petrology and volcanology"). The massive flow (Section 330-U1376A-8R-4 through Core 13R; lithologic Unit 15; stratigraphic Unit III) shows only 0\%-0.5\% vesicle abundance, and most of these vesicles are partly filled with secondary minerals (Fig. F26), predominantly carbonate and clay minerals, throughout the core (Figs. F27, F28). Zeolite infillings are rare. Clay minerals (e.g., saponite) often line vesicle walls, together with carbonate and/or other clay minerals that further fill vesicle interiors (Fig. F27). More oxidized zones within the core also contain Fe oxyhydroxides (goethite/hematite; Fig. F28D-F28F). Botryoidal infillings on vesicle walls in interval 330-U1376A-18R-1, 95-108 cm, were identified as siderite from XRD analysis (Fig. F23).

\section{Vein infillings}

Volcanic rocks from Site U1376 are penetrated by numerous veins. A total of 1190 veins and 280 vein networks were counted, yielding an average vein density of 8.1 veins per meter, which is at least twice as high as that observed at previous sites (see "Structural geology"). Throughout the core these veins are mostly filled with carbonate (Figs. F29, F30), especially the wider veins (as wide as $20 \mathrm{~mm}$ ). Smaller veins are often filled with a mixture of carbonate and dark green and black clay. The highest abundance of carbonate veins occurs in Cores 330-U1376A-5R (38.6-47.12 mbsf), 7R (57.40-66.97 mbsf; within stratigraphic Unit III), and 22R (163.60-171.80 mbsf). The massive $33 \mathrm{~m}$ thick, moderately olivineaugite-phyric basaltic flow of Unit III (Section 330U1376A-8R-5 through Core 13R) shows fewer veins. The secondary mineralogy changes in the lowermost two cores of the hole (Cores $22 \mathrm{R}$ and 23R), interpreted as an aphyric basaltic sheet intrusion, where the common occurrence of zeolite fillings in small veins was first noted (Fig. F29). Additionally, tiny pyrite grains occur along fractures in Section 330U1376A-19R-2 (olivine-phyric basalt) in the middle of Unit IV. A blue coating on the vein rims was occa- 
sionally found in Sections 330-U1376A-7R-1, 7R-2, 7R-3, 15R-3, 15R-4, 23R-5, and 23R-6.

\section{Olivine alteration}

A summary of olivine (and glass) preservation observed in thin section is given in Table T6. Most of the olivine observed in the archive-half sections or thin sections shows varying degrees of alteration, as discussed above. Nevertheless, several intervals contain olivine with $<50 \%$ alteration. In the uppermost $75 \mathrm{~m}$ of core, iddingsite replaces olivine, but it is $\mathrm{mi}-$ nor compared to the green clay alteration. Deeper than 75 mbsf, no iddingsite was observed. From 75 mbsf to the bottom of the hole, the only olivine alteration noted was replacement by green clay and carbonates, which coincides with the overall greenish alteration observed in the rock, indicating persistent reducing conditions throughout the hole.

\section{Glass alteration}

Large amounts of fresh glass are present in the rocks from Site U1376, especially in the hyaloclastites from Unit IV. Significant amounts of this unaltered glass were observed in Cores 330-U1376A-15R through 19R and in Thin Sections 260 (Sample 15R3, 41-44 cm) and 262 (Sample 17R-1, 140-143 cm). However, more highly altered basalt has groundmass glass completely altered to clay minerals or palagonite (Fig. F25E, F25F).

\section{Interpretation of alteration}

Igneous units throughout Hole U1376A are affected by multistage alteration that is mainly produced by low-temperature fluid-rock interactions. The abundance of smectite (saponite and nontronite), celadonite, and carbonates throughout Hole U1376A indicates low temperatures $\left(30^{\circ}-150^{\circ} \mathrm{C}\right)$ typical of the lowest stages of ocean crust alteration (Alt, 1995). The overall paucity of zeolites and the lack of evidence of alteration under oxidizing conditions suggest fluids of different compositions from those that generated the abundant zeolites at Site U1374. Moreover, in contrast to all other sites drilled during Expedition 330, we did not observe any reddish-brownish alteration in the upper part of the basement, with the exception of a few intervals with hematite. This observation complements those of the igneous petrology group (see "Igneous petrology and volcanology") and supports the suggestion that the volcanic units were mostly formed submarine. We therefore conclude that cores from Hole U1376A did not experience weathering and alteration under oxidizing conditions. Nevertheless, the sedimentology group observed some evidence of sedimentary depo- sition in shallow-water environments and discussed the presence of an erosional surface between the sedimentary cover and underlying volcanic basement (see "Sedimentology"). We assume that the upper part of the volcanic basement, which probably experienced weathering and alteration under oxidizing conditions, is therefore missing because of erosion.

Additionally, Site U1376 is characterized by a large number of (relatively thick) carbonate veins, reflecting the strong circulation of Ca-rich fluids within the volcanic basement. This feature was not observed in such abundance at the other Expedition 330 sites. It is possible that the relatively smooth basement topography combined with the algal reef limestone cap (see "Sedimentology") could have restricted the access of oxygenated seawater and influenced the composition of downward-percolating fluids. Additionally, early low-temperature hydrothermal alteration and mineral precipitation in fractures could have reduced permeability and restricted the flow of oxygenated seawater (Alt and Teagle, 2003). The massive basalt lava flow observed in Unit III ( 72-106 mbsf) may also have acted as an impermeable layer, aiding in preserving the lower part of Hole U1376A from pervasive alteration. The precipitation of carbonate is one of the later-stage processes and usually precipitates directly from seawater at temperatures below $50^{\circ} \mathrm{C}$. Carbonate precipitation could be the result of the percolation of Ca-rich fluids that acquired their Ca-rich compositions from the overlying limestone unit (Subunit IIA).

In addition to $\mathrm{Mg}$ calcite, XRD analysis identified aragonite, especially in Sample 330-U1376A-6R-1, 96-98 cm (Fig. F22). The abundance of aragonite in marine sediments is higher in deposits that are younger than the early Cenozoic (Stanley and Hardie, 1998). This could be a result of aragonite being metastable and inverting to calcite in older sediments, or it could reflect an increase in the $\mathrm{Mg} / \mathrm{Ca}$ ratio of seawater since the early Cenozoic because high $\mathrm{Mg} / \mathrm{Ca}$ ratios favor precipitation of aragonite (Stanley and Hardie, 1998). Sr isotopic age determinations for carbonates at ODP Site 707 in the northwest Indian Ocean indicate a temporal change in fluid compositions that led to a progression of aragonite to siderite and to calcite precipitation, although there is some overlap in the precipitation intervals (Burns et al., 1992). This progression in carbonate precipitation might represent an evolution of fluid composition over several million years. A similar age progression in fluid compositions and sequence of carbonate mineral precipitation might also have occurred at Site U1376, but confirmation of this hypothesis will require more extensive shore-based studies. 
We also observed that many veins have fibrous carbonate crystals that grew perpendicular to the vein walls (Fig. F30). Similar features observed during ODP Leg 148 in 6 m.y. old oceanic crust in the equatorial East Pacific were interpreted as a result of repeated opening of filled cracks and sealing by precipitation of additional material from Ca-rich solutions (see "Structural geology").

\section{Structural geology}

Structures observed, measured, and described at Site U1376 on Burton Guyot are sedimentary bedding, geopetals, veins, vein networks, fractures, magmatic flow textures (flow alignment and vesicle bands), and igneous contacts (Fig. F31). The characteristics, orientations, and distribution of these structures at Site U1376 are described below.

Throughout Hole U1376A, veins $(N=1190$, with 1489 individual features) and vein networks $(N=$ 280, with 1995 individual veinlets) are clearly the dominant structural features (Figs. F31, F32, F33, F34, F35). At least two generations of vein growth are indicated in some samples, exemplified by Thin Section 252, which shows an earlier, more coarsely crystalline calcite vein that is crosscut by a later carbonate vein containing cross fibers (Fig. F35A). Hole U1376A has the highest vein density of any hole drilled in the Louisville Seamounts, with a maximum density of 39 veins per meter (Fig. F32), as compared to the previous maximum of 19 veins per meter at Site U1374. Veins are particularly abundant from 42 to 63 mbsf (upper portions of Unit III) and from 146 to 178 mbsf (lower portions of Unit IV), with typically $>20$ veins per meter over these intervals (Fig. F32). Veins are also commonly wider than those observed at other Louisville drill sites, with numerous veins between 5 and $10 \mathrm{~mm}$ wide (Fig. F34) and some as wide as $30 \mathrm{~mm}$, indicating a higher fluid flow in this part of Burton Guyot than that at previous sites. However, similar amounts of veins were observed at the Emperor Seamounts (Tarduno, Duncan, Scholl, et al., 2002). In further contrast to previous sites, veins and vein networks are abundant in hyaloclastites and breccia in addition to the rheologically hard lava units (Fig. F32). Indeed, the highest density of veins per meter in Hole U1376A is found within hyaloclastite units (Fig. F32). These factors taken together indicate that the processes of fluid flow active in this part of Burton Guyot were substantially different than those at the other Louisville sites.

Veins and vein networks at Site U1376 are overwhelmingly shallowly dipping (Figs. F33, F34), with a much higher proportion of subhorizontal veins compared to other Louisville sites. The most com- mon dip angles are $25^{\circ}-30^{\circ}$ for veins (Fig. F33C) and $10^{\circ}-15^{\circ}$ for vein networks (Fig. F33D). This dominance of shallowly dipping veins, combined with their commonly "stepped" habit (Fig. F34) and the occurrence of vertical or near-vertical cross fibers (Fig. F35), requires that the minimum principal stress axis is tension in a subvertical direction (i.e., normal to the vein orientation) (Ramsay and Huber, 1987).

We propose two alternative mechanisms to produce the abundant subhorizontal veins observed at Site U1376. Both mechanisms are related to the position of Site U1376 near the center of Burton Guyot, as opposed to the guyot edge for the other deep Louisville holes. In the first scenario, gravitational unloading during subaerial (wave) erosion of the volcano to sea level (i.e., forming a flat-topped guyot) would cause decompression, with the minimum component of stress in a subvertical direction. Because Site U1376 is located in the center of the seamount, the amount of overburden removed would have been greater than that for other sites drilled in the Louisville Seamounts, leading to a greater abundance of veins. Alternatively, a mechanism for uplift on oceanic volcanoes is magma inflation during growth (Chadwick et al., 2006). Similar to the erosion mechanism, the location of Site U1376 within the core of Burton Guyot would have enhanced the amount of uplift at this site relative to the other Louisville sites. Injection of magma may also have enhanced fluid circulation within the seamount, as may have occurred around 170 mbsf, where numerous veins are located proximal to the dike of lithologic Unit 41.

Fractures are sparse in Hole U1376A, with only 38 recorded in total (Figs. F31, F36). It is likely that most fractures formed were subsequently filled with the abundant vein material that pervades this part of Burton Guyot. The few fractures present are located mostly in massive parts of Units III and IV. These have gentle to moderate dips at a maximum of $20^{\circ}$ $30^{\circ}$ (Fig. F33F).

Sedimentary rocks in Unit I contain prominent bedding (see "Sedimentology"), and the orientations of these layers were recorded in collaboration with the onboard sedimentologists. Dip angles vary mostly from $0^{\circ}$ to $20^{\circ}$, with a maximum at $15^{\circ}$ (Fig. F33A). If the cores can be corrected for drilling-induced rotation, these structural measurements on bedding potentially will yield the paleodeposition direction(s) for these sediments, which will be useful for the sedimentologic reconstruction of this site. Other implications of these dip angles are discussed in "Sedimentology."

Geopetal structures were observed from 23 to 85.5 mbsf, in the limestone of Subunit IIA, the conglom- 
erate of Subunit IIB, and the volcanic basement (Table T7; Fig. F37). Spectacular large geopetals are present in fossils from Subunit IIB (Figs. F8, F9). Geopetal infills are overwhelmingly horizontal, indicating that this part of the seamount experienced negligible tilting after these geopetals were filled.

The lowermost portion of Hole U1376A is cut by two aphyric sheet intrusions (Fig. F10). The first (112112.78 mbsf; lithologic Unit 20) has chilled margins and baked contacts preserved on both the upper and lower margins (Fig. F19). These baked contacts are $<1$ $\mathrm{cm}$ wide, indicating relatively low levels of heat flow from the dike into the country rock, which is consistent with the narrow width of this intrusion. The dike margins are moderately dipping (Fig. F19), but the orientation of vesicle bands from the center of this intrusion (Fig. F19) indicate that magma flow in this dike was subvertical to vertical.

The lower dike (170.80-179.76 mbsf; lithologic Unit 41) is visually different from other sheet intrusions observed at Site U1374 on Rigil Guyot. It is aphyric but also vesicle poor and cut by a dense vein network of thin (typically $0.1 \mathrm{~mm}$ wide), closely spaced veins, often with $\sim 5$ veins per centimeter. The vein orientations in this unit are also different from other rocks in Hole U1376A, with vertical veins dominating (Fig. F33E). These vertical features potentially represent small, infilled cooling or contraction joints subparallel to the dike margins, or they could be related to the direction of magma flow in the intrusion. The upper baked contact of this dike is $<1 \mathrm{~cm}$ wide and steeply dipping. The lower contact was not recovered.

Magmatic foliations were recorded in only four intervals in Hole U1376A (Table T8), which is considerably less frequent than at other Louisville sites. Only one of these occurrences is from an in situ lava (109.3 mbsf; Unit III), indicating that magma flow during crystallization was not a common process in the center of Burton Guyot, as opposed to the seamount flanks sampled in Holes U1372A, U1373A, and U1374A at Canopus and Rigil Guyots. The conglomerate clasts in Subunit IIB indicate that such lava flow processes are present elsewhere on Burton Guyot.

\section{Summary}

Structural features at Site U1376 are dominated by veins ( $N=1190$, with 1489 individual features) and vein networks ( $N=280$ with 1995 individual veinlets). Veins are found in lavas flows, breccia, and hyaloclastites, with a maximum density of 39 veins per meter. The maximum vein width is $30 \mathrm{~mm}$, and numerous veins are $5-10 \mathrm{~mm}$ wide, which is wider than at previous sites, indicating higher levels of fluid flow at Burton Guyot compared to other Louisville sites. Veins are dominantly shallowly dipping, with near-vertical fibrous carbonate crystal growth, indicating that the direction of minimum principal stress was subvertical during vein formation. Potential explanations for this stress regime are uplift and inflation of this part of the seamount during magma injection or decompression due to erosion of the guyot top. A total of 153 cases of sedimentary bedding are present, with the dominant dip angle being $15^{\circ}$. Geopetal structures are overwhelmingly horizontal, indicating that this part of the seamount has not been tilted since deposition of the geopetal infilling material. Only four intervals of magmatic foliation are present (three of which are in conglomerate clasts), demonstrating that significant magma flow was uncommon in the center of Burton Guyot.

\section{Geochemistry Igneous rocks}

Concentrations of major elements and several trace elements were measured for 13 samples of igneous rocks from Site U1376 on Burton Guyot (Table T9) by inductively coupled plasma-atomic emission spectroscopy (see "Geochemistry" in the "Methods" chapter [Expedition 330 Scientists, 2012a] for information on analytical procedures, instrumentation, and data quality). All but three of the samples were collected from lava flows, lobes, and clasts in Units III and IV. Two samples were from aphyric dikes in Unit IV (Samples 330-U1376A-15R-2 [Piece 2, 35-37 $\mathrm{cm}$ ] and 23R-1 [Piece 8, 98-102 cm]), and one was from a lava clast in the conglomerate of Subunit IIB (Sample 5R-2 [Piece 5, 128-130 cm]).

As at previous sites, total weight percentages for the major element oxides vary significantly, in this case from 91.06 to $102.37 \mathrm{wt} \%$. Possible reasons for this variation are discussed in "Geochemistry" in the "Methods" chapter (Expedition 330 Scientists, 2012a). To better compare our results with one another and with data from the literature, we normalized the raw major element values to $100 \mathrm{wt} \%$ totals. The normalized values are presented below the raw data in Table T9 and are used in the figures and in the discussion below.

Weight loss on ignition (LOI) varies from 0.9 to 5.4 wt\%, but only two samples (Unit III Sample 330U1376A-7R-4 [Piece 6, 122-124 cm] and Unit IV Sample 21R-4 [Piece 4, 82-84 cm]) have values of $>2.8 \mathrm{wt} \%$. Values for the other samples indicate moderate overall levels of alteration (for comparison, unaltered basalt is typically characterized by values of $<1$ wt\%; e.g., Rhodes, 1996) and are generally consistent with the petrography of the rocks (see "Alter- 
ation petrology" and "Igneous petrology and volcanology"). Alteration tends to affect $\mathrm{K}_{2} \mathrm{O}$ more than it does any of the other elements analyzed (e.g., see "Geochemistry" in the "Site U1372" chapter [Expedition 330 Scientists, 2012b]). The range in $\mathrm{K}_{2} \mathrm{O}$ at Site U1376 is $0.47-1.56 \mathrm{wt} \%$, and a slight downhole increase is evident in that four of the five samples with $\mathrm{K}_{2} \mathrm{O}>0.90 \mathrm{wt} \%$ are in Unit IV, which corresponds with four of the six samples having LOI $>2.0$ wt $\%$ in Unit IV. However, no overall correlation is present between $\mathrm{K}_{2} \mathrm{O}$ and LOI. Indeed, the two samples with the highest LOI have among the lowest $\mathrm{K}_{2} \mathrm{O}$ concentrations measured ( 0.47 and $\left.0.63 \mathrm{wt} \%\right)$. Nevertheless, alteration has probably modified $\mathrm{K}_{2} \mathrm{O}$ contents to varying amounts because $\mathrm{K}_{2} \mathrm{O}$, which is an incompatible element in mafic systems, does not correlate significantly with the alteration-resistant incompatible elements $\mathrm{TiO}_{2}$ and $\mathrm{Zr}$.

Data for Site U1376 largely overlap with those for Site U1372 on Canopus Guyot in a total alkalis $\left(\mathrm{Na}_{2} \mathrm{O}+\mathrm{K}_{2} \mathrm{O}\right)$ vs. $\mathrm{SiO}_{2}$ diagram, but not with Sites U1373 and U1374 on Rigil Guyot (Fig. F38). Because the Site U1376 samples have comparatively low total-alkali contents relative to their $\mathrm{SiO}_{2}$ values, as a group they are the least alkalic rocks of Expedition 330. Data for most of the samples lie in the field of alkalic basalt, but four samples (Unit III Samples 330U1376A-7R-4 [Piece 6, 122-124 cm] and 13R-4 [Piece $1,0-3 \mathrm{~cm}$ ] and Unit IV Samples 16R-2 [Piece 1, 10$12 \mathrm{~cm}$ ] and 21R-4 [Piece 3, 82-84 cm]) have values that fall below the alkalic-tholeiitic dividing line. Like four similar samples from Site U1372, these rocks are classified as transitional basalt rather than tholeiites because either titanaugite or olivine were identified in their groundmasses (see "Igneous petrology and volcanology").

$\mathrm{Mg}$ number $\left(\mathrm{Mg \#}=100 \times \mathrm{Mg}^{2+} /\left[\mathrm{Mg}^{2+}+\mathrm{Fe}^{2+}\right]\right.$, assuming $\mathrm{Fe}_{2} \mathrm{O}_{3} / \mathrm{FeO}=0.15$ ) varies from 50.8 to 73.3 and averages 64.4, higher than for Sites U1372-U1374 (for which the averages are 50.4, 55.5, and 49.5, respectively). Three of the highest Mg numbers (71.773.3) are found in transitional basalt. The total range in $\mathrm{MgO}$ is considerable (4.91-16.79 $\mathrm{wt} \%)$. However, the average value is high (10.74 wt\%), and seven samples have $\mathrm{MgO} \geq 11.85 \mathrm{wt} \%$. Similarly, Ni varies from 69 to $741 \mathrm{ppm}$, with a high average value of 320 ppm. In an $\mathrm{Al}_{2} \mathrm{O}_{3}$ vs. MgO diagram (Fig. F39A) the Site U1376 data follow a broadly similar trend to other Expedition 330 samples. This trend is indicative of a dominant control on magmatic composition by olivine, with little influence from plagioclase. All of the Site U1376 samples with $\mathrm{MgO} \geq$ $11.85 \mathrm{wt} \%$ contain abundant olivine phenocrysts and are likely to contain excess olivine. For example, within the $33 \mathrm{~m}$ thick massive basalt flow of Unit III, $\mathrm{MgO}$ varies from 12.06 to $15.84 \mathrm{wt} \%$, probably largely as a result of local variation in the amount of olivine phenocrysts. Scandium concentrations at Site U1376 range from 20 to $33 \mathrm{ppm}$ and increase slightly with decreasing $\mathrm{MgO}$, whereas $\mathrm{CaO} / \mathrm{Al}_{2} \mathrm{O}_{3}$ values are relatively high $(\geq 0.78)$ with one exception (Fig. F39B). Although the Unit III rocks contain appreciable amounts of augite phenocrysts (see "Igneous petrology and volcanology"), fractionation of augite in its magma source appears to have been minor overall.

As a group, the Site U1376 basalts tend to have slightly lower $\mathrm{Al}_{2} \mathrm{O}_{3}$ for their $\mathrm{MgO}$ contents than rocks from the other Expedition 330 sites. Unit IV lava Sample 330-U1376A-21R-4 (Piece 3, 82-84 cm), which has the highest $\mathrm{MgO}$ value, stands out in having even lower $\mathrm{Al}_{2} \mathrm{O}_{3}$ relative to its $\mathrm{MgO}$ content (Fig. F39A). Its $\mathrm{Al}_{2} \mathrm{O}_{3}$ concentration is the lowest encountered during Expedition 330, and its $\mathrm{CaO} / \mathrm{Al}_{2} \mathrm{O}_{3}$ is the highest (Fig. F39B). This sample does not contain augite phenocrysts, so the high $\mathrm{CaO} / \mathrm{Al}_{2} \mathrm{O}_{3}$ is not caused by augite accumulation. Aluminum is not very sensitive to alteration, but $\mathrm{CaO}$ contents can be modified by some types of alteration (e.g., see "Geochemistry" in the "Site U1372" chapter [Expedition 330 Scientists, 2012b]). Even though the sample has the highest LOI value measured for Site U1376, its high $\mathrm{CaO} / \mathrm{Al}_{2} \mathrm{O}_{3}$ is not a result of high $\mathrm{CaO}$ but of low $\mathrm{Al}_{2} \mathrm{O}_{3}$. A low $\mathrm{Al}_{2} \mathrm{O}_{3}$ content in a high-MgO rock is suggestive of relatively small amounts of partial melting with residual garnet in the mantle source. This sample also has higher $\mathrm{Fe}_{2} \mathrm{O}_{3}{ }^{\top}$ (total iron as $\mathrm{Fe}_{2} \mathrm{O}_{3}$ ) than the other high-MgO samples (Fig. F39C) and also is consistent with relatively high pressure melting in the garnet stability field. On the other hand, the sample has $\mathrm{Zr} / \mathrm{Y}, \mathrm{Ba} / \mathrm{Y}$, and $\mathrm{Ti} / \mathrm{Y}$ ratios similar to those of the other Unit IV lava samples. Melts formed from a source with residual garnet should have higher values of these ratios than melts from garnet-free sources because $\mathrm{Y}$, unlike $\mathrm{Zr}, \mathrm{Ba}$, or $\mathrm{Ti}$, is compatible in garnet. Thus, the composition of this sample presently remains somewhat puzzling.

Incompatible trace element characteristics of the Site U1376 basalt generally resemble those of Sites U1372-U1374 (e.g., Fig. F40). The greatest overlap is with Site U1372. Within Site U1376, chemical distinctions can be drawn approximately along stratigraphic unit lines. Except for highly olivine-phyric Unit IV Sample 330-U1376A-21R-4 (Piece 3, 82-84 $\mathrm{cm})$, Unit III has the highest $\mathrm{Ni}, \mathrm{Cr}$, and $\mathrm{MgO}$ contents and $\mathrm{Mg}$ numbers (e.g., Fig. F41A, F41B) and the lowest $\mathrm{TiO}_{2}, \mathrm{Sr}, \mathrm{Zr}$, and $\mathrm{Y}$ concentrations (e.g., Fig. F41C). Moreover, variations in these quantities 
within Unit III, including both the three samples from the $33 \mathrm{~m}$ thick flow and the basalt from lithologic units above and below this flow, are small relative to those within Unit IV. The uppermost Unit IV lava Sample 330-U1376A-16R-2 (Piece 1, 10-12 cm) is chemically similar to Unit III in $\mathrm{Mg}$ number, $\mathrm{Ni}$ and $\mathrm{TiO}_{2}$ contents, and $\mathrm{Zr} / \mathrm{Y}$ ratio (e.g., Fig. F41AF41D). The Unit II lava clast (an olivine-phyric Type 1 clast; see "Igneous petrology and volcanology") broadly resembles the two lowest-MgO olivine-phyric Unit IV lava samples in some respects (e.g., Fig. F41A, F41B), but it has a distinctly lower $\mathrm{Zr} / \mathrm{Y}$ ratio (5.92) than that measured for any sample from either Units III or IV (Fig. F41D). Values of $\mathrm{Zr} / \mathrm{Y}$ for Unit III and the uppermost lava sample from Unit IV vary between 6.87 and 7.13, whereas values for the remaining Unit IV lava samples are even higher, varying between 7.61 and 8.05. This ratio, which is insensitive to fractional crystallization or crystal accumulation of olivine, clinopyroxene, or plagioclase, is an indicator of variation in the amount of partial melting and/or in mantle source composition. Thus, three distinct magma types appear to be present among the Site U1376 lava samples, and these correlate approximately with petrographically defined Units II-IV. Interestingly, downhole differences in $\mathrm{Ba} / \mathrm{Y}$ among the lava samples of the three stratigraphic units are much less pronounced than those in $\mathrm{Zr} / \mathrm{Y}$. Yet in mafic and ultramafic systems, the difference in incompatibility between $\mathrm{Ba}$ and $\mathrm{Y}$ is greater than that between $\mathrm{Zr}$ and $\mathrm{Y}$. Therefore, for a given range of partial melting, the $\mathrm{Ba} / \mathrm{Y}$ ratio ordinarily varies more in magmatic rocks than the $\mathrm{Zr} / \mathrm{Y}$ ratio. That this is not observed at Site U1376 suggests that the differences in $\mathrm{Zr} / \mathrm{Y}$ may reflect source differences rather than variations in partial melting. Finally, the chemical characteristics of the aphyric basalt dike near the bottom of Unit IV are not significantly different from those of the two olivinephyric Unit IV lava samples from Sections 330U1376A-17R-3 and 19R-1. The dike near the top of Unit IV is similar in some respects but has significantly higher $\mathrm{Ba} / \mathrm{Y}$ than any of the other Site U1376 basalts (Fig. F41E).

\section{Carbon, organic carbon, nitrogen, and carbonate}

No samples from Site U1376 were analyzed for carbonate, total carbon, total organic carbon, or total nitrogen content.

\section{Physical properties}

Characterization of physical properties was conducted for rocks recovered from Hole U1376A through measurements on whole-round and split- core sections and discrete samples. Measurements of gamma ray attenuation (GRA) bulk density, wholeround and point magnetic susceptibility, laser height, and color reflectance were conducted on all 121 core sections recovered from this hole. Wholeround core sections longer than $\sim 50 \mathrm{~cm}$ (117 of 121 available sections) were also run through the Natural Gamma Radiation Logger (NGRL). Discrete measurements included compressional wave ( $P$-wave) velocity and moisture and density measurements on 71 discrete oriented rock cubes. Most of these discrete samples were also used for paleomagnetic measurements of alternating-field demagnetization (see "Paleomagnetism"). No thermal conductivity measurements were made because of equipment failure earlier in the expedition. In accordance with core depth below seafloor Method A (CSF-A) conventions to reference cores to depth (see "Procedures" in the "Methods" chapter [Expedition 330Scientists, 2012a]), data from cores with $>100 \%$ recovery (e.g., Cores 330-U1376A-12R and 13R) are shown in figures as overlapping. In general, all physical property data sets are mutually consistent and show distinctions and trends often correlating with lithologic changes and stratigraphic unit boundaries (see "Igneous petrology and volcanology") and with petrologically determined alteration trends (see "Alteration petrology").

\section{Whole-Round Multisensor Logger measurements}

Throughout the lithified sediments and igneous basement of Site U1376, individual sections generally contain multiple discrete pieces, as is typical of hard rock coring. In order to remove spurious Whole-Round Multisensor Logger (WRMSL) and Section Half Multisensor Logger (SHMSL) data affected by the gaps and edge effects from these discontinuities, we applied a data filtering and processing algorithm (see "Physical properties" in the "Methods" chapter [Expedition 330 Scientists, 2012a]). In this report we show only the filtered data; for raw data we refer the reader to the visual core descriptions (see "Core descriptions") and the Laboratory Information Management System (LIMS) database (iodp.tamu.edu/tasapps/).

\section{Magnetic susceptibility}

Magnetic susceptibility is sensitive to the mineralogical composition of the rock. Whole-round magnetic susceptibility measurements are shown in Figure F42. The depth profile for magnetic susceptibility at this site consists of distinct short-wavelength peaks with values that exceed $1.00 \times 10^{-2} \mathrm{SI}$, as well as broad regions of consistently lower values. 
Stratigraphic Unit I, composed of lithified volcanic sediments, has a relatively low average magnetic susceptibility of $1.31 \times 10^{-3}$ SI. However, the unit begins and terminates with comparatively high values, whereas the middle portion is characterized by very low consistent magnetic susceptibility measurements. This pattern likely reflects the higher proportion of relatively fresh basalt clasts near the unit boundaries. The algal limestone of Subunit IIA is marked by very low magnetic susceptibility that increases slightly toward the base of the unit. This pattern agrees well with the observation that the upper portion is composed mostly of carbonate material, whereas the lower portion has increasing amounts of volcanic sediments incorporated into the structure (see "Sedimentology"). In the conglomerate, highs in magnetic susceptibility are associated with both larger basaltic clasts and black sandy intervals. In the upper portion of Unit III, the marked highs are associated with intervals dominated by hyaloclastites, rather than with lava lobes, flows, or pillows.

A marked increase in magnetic susceptibility occurs at $72 \mathrm{mbsf}$ and remains relatively consistent down to 105 mbsf. This interval has an average magnetic susceptibility of $4.16 \times 10^{-3}$ SI and coincides with the identification of a $33 \mathrm{~m}$ thick lava flow (see "Igneous petrology and volcanology"). A slight downhole increase in average magnetic susceptibility from $3.89 \times 10^{-3}$ SI to $4.53 \times 10^{-3}$ SI was observed in this interval. In contrast, the volcanic breccia from the upper portion of stratigraphic Unit IV yields consistently low magnetic susceptibility values (average = $1.27 \times 10^{-3} \mathrm{SI}$ ), whereas the breccia found below 135 mbsf is characterized by much higher values (average $=4.66 \times 10^{-3} \mathrm{SI}$ ) and significantly more scatter. This change likely represents the transition from hyaloclastite-dominated breccia to a multilithic volcanic breccia containing both aphyric and olivine-phyric basalt clasts. The dikes represented by lithologic Units 20 and 41 have a magnetic susceptibility close to that of the thick lava flow, with an average of 3.92 $\times 10^{-3}$ SI.

\section{Gamma ray attenuation bulk density}

The results of GRA-derived bulk density are shown in Figure F43. A correction factor of 1.138 was applied to account for the smaller average diameter $(58 \mathrm{~mm})$ of hard rock cores compared to the full core liner diameter of $66 \mathrm{~mm}$ (see "Physical properties" in the "Methods" chapter [Expedition 330 Scientists, 2012a]). Values of $<1.00 \mathrm{~g} / \mathrm{cm}^{3}$ were attributed to empty portions of core liner and removed. Bulk density at this site ranges from 1.17 to $3.19 \mathrm{~g} / \mathrm{cm}^{3}$, with an average of $2.50 \mathrm{~g} / \mathrm{cm}^{3}$.
Although a significant amount of scatter in GRA-derived bulk density values was observed for much of the core, as is typical of volcanic breccia, a number of trends were identified in the stratigraphic and lithologic units. The lithified volcanic sediments of stratigraphic Unit I have a relatively low average bulk density of $2.00 \mathrm{~g} / \mathrm{cm}^{3}$ and demonstrate a downhole-decreasing trend. This trend terminates at the beginning of Subunit IIA, at which point a slight downhole-increasing trend begins for the carbonate material, which averages $2.43 \mathrm{~g} / \mathrm{cm}^{3}$. The highest observed bulk density was found in the interval from 72 to 105 mbsf, which correlates with a thick olivine-phyric lava flow. GRA-derived bulk density measurements in this interval have remarkably little scatter, with an average of $2.96 \mathrm{~g} / \mathrm{cm}^{3}$. A slight, steady increase with depth from 2.93 to $3.02 \mathrm{~g} / \mathrm{cm}^{3}$ was also discernible for this flow, and this trend may correlate with a subtle decrease in porosity or an increase in the percentage of olivine phenocrysts. Other more localized increases in GRA-derived bulk density throughout the core can generally be attributed to lava flow lobes and dikes in the volcanic breccia, which has a background average of $2.44 \mathrm{~g} / \mathrm{cm}^{3}$. A localized decrease in density was also observed from 123.5 to $126 \mathrm{mbsf}$, corresponding to an interval of hyaloclastite with very few basaltic clasts.

\section{Natural Gamma Radiation Logger}

Natural gamma radiation (NGR) measurements reflect the combined total amount of uranium, thorium, and potassium present in the rock. Results from the NGRL are shown in Figure F44. NGR ranges from 0.49 to 26.42 counts per second (cps), with an average value of $12.42 \mathrm{cps}$.

Although variable, many of the highest NGR values measured at this site occur in the volcanic sandstone of Unit I. The algal limestone of Subunit IIA exhibits the lowest levels of NGR measured during the expedition, with an average of 1.64 cps. NGR counts for the base of this carbonate interval are as high as $12.32 \mathrm{cps}$ near the lowermost recovered portion of Subunit IIA and then sharply decrease uphole to a site minimum of $0.49 \mathrm{cps}$. This decrease likely reflects the transition from a volcanically influenced depositional environment to a clastic-free shallowmarine environment (see "Sedimentology"). The upper portion of stratigraphic Unit III displays moderate variability in NGR, reflecting both lithologic and alteration changes. The peaks at 42 and 46 mbsf occur in the breccia and correlate with increased alteration, whereas those at 52 and 55 mbsf correlate with lava flow lobes. 
Below these localized peaks, the interval from 60 to $130 \mathrm{mbsf}$ is characterized by an essentially featureless band of NGR between 9 and 14 cps, with an average of $12.06 \mathrm{cps}$, interrupted by a single peak associated with the dike of lithologic Unit 20 (recovered in the uppermost part of stratigraphic Unit IV). Unlike magnetic susceptibility and GRA-derived bulk density measurements, NGR results show no distinctive signature associated with the $33 \mathrm{~m}$ thick massive lava flow of Unit III. The volcanic breccia below 130 mbsf has a lower overall average of $9.26 \mathrm{cps}$ but demonstrates a downhole-increasing trend, culminating with moderate values of 10-20 cps, representing the lowermost dike (lithologic Unit 41). Short-wavelength peaks in this interval correlate well with the intercalated lava flow lobes.

\section{Section Half Multisensor Logger measurements}

\section{Color reflectance spectrometry}

Color reflectance spectrometry results are summarized in Figure F45. L* (lightness) of the recovered core has a median value of 33.4. The algal limestone composing Subunit IIA has markedly higher $L^{*}$ than the rest of the hole (median value $=71.1$ ), reflecting the bright white nature of this carbonate lithology. Although it remains very high throughout the algal limestone of Subunit IIA, L* also exhibits a downhole-decreasing trend that correlates with the increasing percentage of volcanic grains in this limestone from top to bottom (see "Sedimentology"). The other sedimentary units (stratigraphic Unit I and Subunit IIB) also exhibit higher $\mathrm{L}^{*}$ values than the site average, but not nearly to the degree of the algal limestone. $\mathrm{L}^{*}$ is relatively uniform in magnitude and variance in most of the igneous basement but is slightly reduced in both magnitude and variance for the interval from $\sim 112$ to 123 mbsf. This region of Unit IV is composed of a higher proportion of hyaloclastites containing a high proportion of fresh volcanic glass (see "Igneous petrology and volcanology"). Also, the median absolute deviation of $L^{*}$ in the olivine-phyric breccia below 130 mbsf is significantly higher (10.2) than that for both the olivineaugite-phyric breccia and olivine-phyric breccia above 130 mbsf (6.7 and 7.4, respectively). This indicates a statistically higher amount of scatter in $\mathrm{L}^{*}$ in the lower portion of Unit IV than in the rest of the igneous material, possibly reflecting the multilithic nature of this breccia.

Figure F45 also shows values of $\mathrm{a}^{*}$ and $\mathrm{b}^{*}$, which correspond to redness versus greenness and yellowness versus blueness, respectively. The sedimentary rocks of Unit I are characterized by strongly red and yellow spectra, with an especially high amount of scatter in the $b^{*}$ values representing variations in the degree of yellowness. The amount of scatter likely reflects the range of clast types in these volcanic sediments. The overall redness and yellowness of this unit may be indicative of an oxidizing environment during deposition. The color reflectance values of the algal limestone of Subunit IIA also correspond to predominantly red and yellow spectra, with local variations possibly attributed to a slight increase in iron oxides compared to the surrounding limestone.

Igneous stratigraphic Units III and IV have a predominantly green to red/green neutral spectrum consistent with the predominantly green alteration (see "Alteration petrology"). The $\mathrm{a}^{*}$ and $\mathrm{b}^{*}$ values from igneous Units III and IV also demonstrate a distinct inverse relationship, such that when $\mathrm{a}^{*}$ transitions to a more green spectrum (more negative), $\mathrm{b}^{*}$ transitions to a more yellow spectrum (more positive), and vice versa. The significance of this pattern, which was not identified at any of the previous Expedition 330 sites, is unclear. The volcanic breccia exhibits a predominantly green and yellow spectrum to 127 mbsf, below which no clear relationship between lithologic units and color reflectance can be discerned. This observation may reflect a transition from breccia containing olivine-phyric clasts to multilithic breccia containing both aphyric and olivinephyric basalt clasts. The addition of blue-gray aphyric basalt clasts may shift the otherwise green and yellow spectrum of the breccia to neutral $\mathrm{a}^{*}$ and negative (blue) $b^{*}$ values. The thick lava flow from 72 to 105 mbsf is characterized by a moderate reduction in the short-wavelength scatter of $a^{*}$ and $b^{*}$ but is not otherwise delimited by color reflectance data, showing several subtle variations between a red/ green neutral and blue spectrum and a green and yellow one.

\section{Point magnetic susceptibility}

Point magnetic susceptibility results are shown in Figure F42 together with whole-round magnetic susceptibility data. The pattern of peaks and troughs in this data set agrees well with the whole-round data, but the point magnetic susceptibility results are consistently lower than the whole-round results. The average values for point magnetic susceptibility are $1.01 \times 10^{-3} \mathrm{SI}$ for the volcanic sandstone, $3.41 \times 10^{-4}$ SI for the carbonates, $2.92 \times 10^{-3} \mathrm{SI}$ for the thick olivine-phyric lava flow, and $2.22 \times 10^{-3}$ SI for the volcanic breccia.

\section{Moisture and density}

Bulk density, dry density, grain density, void ratio, water content, and porosity measurements on discrete samples are listed in Table T10. Bulk density 
ranges from 1.75 to $3.10 \mathrm{~g} / \mathrm{cm}^{3}$, with an average of $2.54 \mathrm{~g} / \mathrm{cm}^{3}$. Porosity ranges from $1.2 \%$ to $57.9 \%$, with an average of $18.2 \%$. As illustrated in Figure F46, a strongly linear negative correlation between bulk density and porosity was observed. Bulk density measurements from discrete samples also agree well with GRA-derived bulk density measurements, as shown by Figure F47. The near one-to-one linear relationship between these two data sets supports our 1.138 volume correction factor for GRA-derived bulk density. GRA-derived bulk density values may be affected by the presence of fractures and cracks in the whole-round cores, slight variations in core radius (approximately $\pm 1-2 \mathrm{~mm}$ ), and distortions of the core's cylindrical shape near piece ends or from large voids. These factors can all cause overestimates of the total volume used in the GRA-derived bulk density calculations even after the correction factor is applied, thus explaining why some GRA-derived bulk densities remain slightly lower than the corresponding results from discrete samples.

Figure F43 shows the variation of bulk density with depth based on both discrete samples and GRAderived bulk density and further illustrates the strong correlation between the two. In the sedimentary units, a sharp transition is observed between the volcanic sandstone of Unit I, which has an average bulk density value of $2.08 \mathrm{~g} / \mathrm{cm}^{3}$, and the algal limestone of Subunit IIA, which has an average of $2.62 \mathrm{~g} / \mathrm{cm}^{3}$, as determined from discrete sample measurements. Bulk density is consistently high throughout the massive $33 \mathrm{~m}$ thick lava flow within stratigraphic Unit III (lithologic Unit 15), with an average of $3.03 \mathrm{~g} / \mathrm{cm}^{3}$, and also demonstrates a slight downhole increase, as previously noted for GRA-derived bulk density. The highly variable values obtained for measurements on discrete samples from the volcanic breccia intervals further illustrate their heterogeneous nature.

Figure F48 shows the variation of porosity with depth. The volcanic sandstone of Unit I is characterized by high porosity, averaging 38.4\%. In Subunit IIA, the algal limestone has low porosity, with an average of $4.8 \%$. These samples also deviate from the general linear trend between density and porosity (Fig. F46), illustrating their distinct chemical composition. In the volcanic basement, porosity in the volcanic breccia is highly variable, reflecting the contrasts between hyaloclastite matrix and basaltic clasts and flow lobes. Within the $33 \mathrm{~m}$ thick massive flow in stratigraphic Unit III, porosity is consistently very low, averaging $1.9 \%$, and decreases slightly with depth. This downhole decrease in porosity explains part of the increase in bulk density. However, the grain density increases with depth, albeit with more scatter, suggesting that an increase in olivine may still contribute to the downhole increase in density. Five samples from the volcanic breccia in Cores 330U1376A-14R through 16R show distinctly low density, lower than the GRA-derived bulk density (Fig. F43), and disproportionately low porosity relative to their density (Fig. F46). These samples are from an interval containing increased amounts of comparatively fresh hyaloclastite, so this unique signature could possibly be attributed to smectite infilling of vesicles or to sealed void spaces within the hyaloclastite that are not included in the porosity measurement.

\section{Compressional wave ( $P$-wave) velocity}

The measured $P$-wave velocity of discrete samples shows a strong linear relationship with bulk density (Fig. F49). Downhole variations in $P$-wave velocity are shown in Figure F43 and Table T11. $P$-wave velocities are widely scattered in general because much of the material is breccia with intermittent lava flows, leading to large variability over even short depth intervals. $P$-wave velocities in Hole U1376A range from 1.78 to $7.21 \mathrm{~km} / \mathrm{s}$, with an average of $4.65 \mathrm{~km} / \mathrm{s}$. The lowest compressional wave velocities were measured in the volcanic sandstone of Unit I (average $=2.97 \mathrm{~km} / \mathrm{s}$ ). The algal limestone of Subunit IIA, by contrast, has a significantly higher average velocity of $6.19 \mathrm{~km} / \mathrm{s}$. These samples also form a distinct population in Figure F49, reflecting their distinct chemical composition. In the volcanic basement, many of the highest values can be attributed to lava flow lobes in basalt breccia, particularly the thick olivine-phyric basalt flow from $\sim 72$ to 105 mbsf. This interval is marked by highly consistent $P$-wave velocity measurements averaging $6.84 \mathrm{~km} / \mathrm{s}$. In the volcanic breccia itself, measurement of relatively high or low $P$-wave velocity depends on whether the discrete sample was taken from a large clast or the surrounding groundmass, respectively. Most samples show no statistically significant anisotropy; of those that do, the anisotropy has no consistent relationship with depth or lithology.

\section{Paleomagnetism}

Archive-half core and discrete sample remanent magnetizations provide a consistent pattern of moderate to steep positive inclinations, reflecting Southern Hemisphere reversed polarity. Positive inclinations in the volcanic sandstone and limestone are similar to those in the underlying volcanic basement (including some breccia units). No magnetic reversals were observed for Site U1376 on Burton Guyot. 


\section{Archive-half core remanent magnetization data}

Remanent magnetization of the archive halves of Cores 330-U1376A-1R through 23R was measured at $2 \mathrm{~cm}$ intervals using the cryogenic magnetometer. All data acquired within $4.5 \mathrm{~cm}$ of either piece end were filtered out prior to further processing, and thus only pieces longer than $9 \mathrm{~cm}$ were considered.

The natural remanent magnetization (NRM) intensity varies by $>5$ orders of magnitude (Fig. F50B) from a minimum of $2.51 \times 10^{-4} \mathrm{~A} / \mathrm{m}$ (in sediments of Subunit IIA) to a maximum of $9.34 \mathrm{~A} / \mathrm{m}$ (associated with lava lobes or fragments in Core 330-U1376A19R; lithologic Unit 29). The most abrupt variation in NRM intensity and magnetic susceptibility occurs at the boundary between Unit I and Subunit IIA (Fig. F50B, F50C). The heterolithic volcanic breccia and volcanic sandstone at the base of Unit I are characterized by NRM intensities and susceptibilities that are $\sim 3$ orders of magnitude higher than those for the white algal limestone at the top of Subunit IIA. Both NRM and susceptibility increase systematically with depth throughout Subunit IIA and into the heterolithic conglomerate of Subunit IIB. Significant NRM intensity and magnetic susceptibility variations also occur in the volcanic basement (Units III and IV). Lava flows and dikes typically have NRM intensities in the range of $1-10 \mathrm{~A} / \mathrm{m}$, and this same range of variations is also apparent in the $33 \mathrm{~m}$ thick massive lava flow (lithologic Unit 15; 72.21-105.32 mbsf). The magnetization of volcanic breccia is quite variable. For example, the hyaloclastite breccia of lithologic Unit 21 ( 114-127 mbsf) has NRM values that range from $>1 \mathrm{~A} / \mathrm{m}$ to low values $\left(\sim 10^{-3} \mathrm{~A} / \mathrm{m}\right)$, similar to that of the weakly magnetized limestone recovered at this site.

Best-fit principal component directions were calculated from alternating-field (AF) demagnetization data for each $2 \mathrm{~cm}$ interval of the archive halves using an automated routine that maximizes the percentage of remanence incorporated and minimizes the scatter about the best-fit direction and the deviation of this vector from the origin (see "Paleomagnetism" in the "Methods" chapter [Expedition 330 Scientists, 2012a]). On the basis of the distribution of misfit values, only directions with misfit values of $<2.56$ were considered, which represents the most reliable $40 \%$ of the total number of $2 \mathrm{~cm}$ interval principal component directions (see black and bright red circles in Fig. F50B, F50D). The significantly lower misfit value employed at this site suggests that the overall quality of the data set measured here is higher than that at Sites U1372, U1373, and U1374, where the misfit cutoff value was set at $\sim 3.4$. The re- sulting inclinations, intensities, and stability of remanent magnetization, as represented by the median destructive field ( $\left.\mathrm{MDF}^{\prime}\right)$ of the vector difference sum, are shown in Figure F50D, F50B, and F50E, respectively.

Hole U1376A is dominated by positive inclinations, indicative of Southern Hemisphere reversed polarity (Fig. F50D). Only 1\% of reliable data have negative inclinations. The uniform positive inclination is most evident in the $33 \mathrm{~m}$ thick lava flow (lithologic Unit 15), but a comparable signal is present in the volcanic breccia, dikes, and thinner lava flows in Units III and IV, including intervals of volcanic breccia and pillow fragments (e.g., Cores 330-U1376A-6R and $7 \mathrm{R}$ ) with best-fit directions that have misfits exceeding the cutoff value of 2.56 (see light red circles in Fig. F50D). The algal limestone (Subunit IIA) shows the same consistent reversed polarity magnetization as the sequence stratigraphically below. The volcanic sandstone and volcanic breccia of Unit I also appear to have the same polarity, although inclinations are more scattered and many of the best-fit directions have misfit values that exceed the cutoff value.

\section{Discrete sample remanent magnetization data}

The remanent magnetization of 99 discrete samples from Hole U1376A was measured with the spinner magnetometer. NRM intensities range from $1.3 \times 10^{-4}$ $\mathrm{A} / \mathrm{m}$ to $11.3 \mathrm{~A} / \mathrm{m}$ (Fig. F51; Table T12) and are generally consistent with those determined from the same interval on archive halves. The lowest values are determined for hyaloclastite breccia samples from Core 330-U1376A-15R. The highest NRM intensities occur in lava flows, but only slightly lower magnetizations characterize many of the basalt clasts in volcanic breccia and heterolithic breccia units. Königsberger ratio (Qn) values of basalts (lavas, intrusive sheets, and clasts in volcanic breccia/conglomerate) are all $>1$ and typically $\sim 5$ or higher, indicating that the magnetization is dominated by remanent magnetization. Samples from hyaloclastite and the matrix of volcanic breccia display a wide range of $Q n$ values, with the highest values corresponding to basalt samples and generally lower values (as low as $\sim 0.01$ ) corresponding to hyaloclastite samples and the matrix of volcanic breccia.

Stepwise AF and thermal demagnetization were applied to 60 and 39 samples, respectively (Table T12). Demagnetization results from basalt samples reveal relatively simple behavior and are generally consistent with the steep positive inclinations observed in the archive-half data. Samples from volcanic sand- 
stone, the relatively finer grained matrix of volcanic breccia/conglomerate, and limestone from Units I and II yielded positive inclinations, indicating reversed polarity (Fig. F52A). In several cases, particularly for samples with weak magnetization, the scatter of the best-fit direction was greater than the maximum angular deviation cutoff of $5^{\circ}$, and the characteristic remanent magnetization direction in these cases was not plotted or considered when evaluating the mean inclination for the site. In addition, a malfunction in the AF demagnetizer (DTech D-2000) resulted in five sediment samples (all from Units I and II) acquiring a spurious magnetization at the $5 \mathrm{mT}$ step (see also "Paleomagnetism" in the "Site U1375" chapter [Expedition 330 Scientists, 2012d]).

$\mathrm{AF}$ and thermal demagnetization reveal the same magnetization component(s) for most basalt samples. This is true regardless of whether the basalt samples have high stability (e.g., vesicular pillow basalt samples from lithologic Unit 2; Fig. F52B) or more moderate stability characteristic of the $33 \mathrm{~m}$ thick lava flow of lithologic Unit 15 (Fig. F52C). In contrast, thermal and AF results from volcanic breccia and hyaloclastite units can yield different results (Fig. F52D). AF demagnetization typically reveals a single high-coercivity component of reversed polarity. This component apparently coincides with the lower unblocking-temperature magnetization component during thermal demagnetization, whereas at the highest unblocking temperatures an additional component is present. At present, it is not clear what the significance of this small, high-temperature component is; the better-defined low-temperature component is reported in Table T12.

The unblocking temperature spectra from thermal demagnetization studies provide some indication of the magnetic mineralogy of the samples. Many basalt samples, including those from the thick lava flow of lithologic Unit 15, have relatively low unblocking temperatures. In these samples, much of the remanence is removed by $\sim 250^{\circ} \mathrm{C}$, consistent with the dominance of Ti-rich titanomagnetite that has undergone little or no deuteric oxidation. In other samples, maximum unblocking is concentrated near $575^{\circ}-600^{\circ} \mathrm{C}$ (Fig. F52B) or in a few cases extends well above $580^{\circ} \mathrm{C}$ and is accompanied by very high coercivity (Fig. F52E). These high unblocking temperatures probably indicate the presence of Ti-poor magnetite or (titano)hematite; both phases can be associated with high-temperature deuteric oxidation of titanomagnetite that is more common in subaerial lavas. A possible subaerial origin was suggested for highly vesicular lava fragments in lithologic Unit 26 (see "Igneous petrology and volcanology") that oc- cur only a few meters stratigraphically above the samples shown in Figure F52E. The magnetic mineralogy and the implications for the origin of the remanent magnetization will be the subject of shore-based studies.

\section{Anisotropy of magnetic susceptibility}

The anisotropy of magnetic susceptibility was determined for all discrete samples (Table T13). A significant fraction $(20 \%)$ of the samples, primarily those from sedimentary and hyaloclastite breccia units, are statistically isotropic. The remaining samples have an average degree of anisotropy $\left(\mathrm{P}^{\prime}\right)$ of 1.02 and shape factors $(\mathrm{T})$ ranging from -0.84 to 0.87 (where $\mathrm{T}=-1$ if prolate, and $\mathrm{T}=1$ if oblate; Jelinek, 1981). The $33 \mathrm{~m}$ thick massive flow of lithologic Unit 15 does not have a consistent magnetic fabric (i.e., the eigenvectors associated with the minimum eigenvalues have a broad range of inclinations rather than the subvertical distribution expected for horizontal lava flows).

\section{Discussion}

The dominance of moderately to steeply dipping positive inclinations is further highlighted in Figure F53, which shows the average inclinations calculated using inclination-only statistics (Arason and Levi, 2010) for the $2 \mathrm{~cm}$ interval data and the Fisher pieceaverage data (see "Paleomagnetism" in the "Methods" chapter [Expedition 330 Scientists, 2012a]). In both cases, only a very limited number of lithologic units have shallow positive or negative inclinations (Fig. F53C, F53E) for which a low in situ confidence index (ISCI; see "Igneous petrology and volcanology") of either 1 (lithologic Units 22, 31, and 39) or NA (lithologic Units 11 and 13) were assigned.

The most striking observation from Figure F53 is the coherence of inclinations in lithologic Unit 15, a single $33 \mathrm{~m}$ thick lava flow that represents a short interval of time. Figure F54 focuses on the depth interval 65-110 mbsf and highlights the limited variation in all the magnetic parameters measured. What limited variation does exist is not obviously related to the mapped flow boundaries. Nearby lithologic Units 14 and 17 have similarly high ISCIs, but these units exhibit relatively more scatter in intensity, stability $\left(\mathrm{MDF}^{\prime}\right)$, and inclination than lithologic Unit 15, although less scatter in magnetic susceptibility. The average inclination for lithologic Unit 15 is $71.9^{\circ} \pm$ $0.4^{\circ}(N=909)$ when calculated from $2 \mathrm{~cm}$ interval data and $70.1^{\circ} \pm 0.9^{\circ}(N=95)$ when calculated with Fisher piece-average data (Fig. F54E, F54F; Table T14).

The upper and lower boundaries of lithologic Unit 15 have a distinct magnetic signal. Three Zijderveld 
diagrams from lithologic Unit 14 are shown in Figure F55B. These samples show a progressive change from high to low coercivity with decreasing distance from the top of the massive flow. This change is also illustrated graphically by the systematic decrease in $\mathrm{MDF}^{\prime}$ (light blue circles in Fig. F55A) and supports the interpretation that the contact is gradational (see "Igneous petrology and volcanology"). The base of lithologic Unit 15 occurs in Section 330-U1376A$13 \mathrm{R}-4,59 \mathrm{~cm}$. In the lowermost $20 \mathrm{~cm}$ of the massive flow unit, MDF' begins to increase again to values representative of lithologic Unit 16 stratigraphically below (light blue circles in Fig. F55C). Over this same interval there is a pronounced increase in magnetic susceptibility. The Zijderveld diagrams associated with measurements toward the base of lithologic Unit 15 (Fig. F55D) show a progressive increase in coercivity to values characteristic of lithologic Unit 16 (Fig. F55E). Together with magnetic data, the presence of hyaloclastite material similar to lithologic Unit 16 at $\sim 45 \mathrm{~cm}$ in the section suggests that the base of lithologic Unit 15 might be more appropriately located at $\sim 40 \mathrm{~cm}$. This area will be studied in more detail, and a baked contact test will be carried out as part of shore-based research.

Inclination data from archive halves and discrete samples from Hole U1376A provide a remarkably consistent picture of moderate to steep reversed polarity magnetization (Fig. F56). The most abundant inclination data are from the unfiltered $2 \mathrm{~cm}$ archive-half measurements. These data show a pronounced peak near $70^{\circ}\left(\right.$ median $=67.7^{\circ}$ ) but a significant number of shallower positive to negative inclinations (Figs. F53A, F56A). The highest-quality archive-half data (misfit $\leq 2.56$ ) have an even narrower distribution, with a median value of $70.7^{\circ}$ (Fig. F56B). If intervals with low $(<2)$ ISCI values are excluded, the distribution changes relatively little (Fig. F56C). The remaining data (ISCI $=3$ or 2 ) yield an inclination-only mean of $72.2^{\circ} \pm 0.5^{\circ}\left(\alpha_{95}\right)$. Fisher piece-average directions from individual archive-half core pieces should provide a more robust estimate of average inclination because pieces with heterogeneous magnetization can be recognized by their high circular standard deviation (CSD) values (with CSD > $20^{\circ}$ being excluded). These piece-average inclinations, after removal of three negative inclinations, result in an inclination-only mean of $69.4^{\circ} \pm 1.2^{\circ}$ $\left(\alpha_{95}\right)$ (Fig. F56D). Finally, inclinations from discrete samples also show a similar inclination value. The inclination-only mean for all discrete samples with positive inclinations is $66.7^{\circ} \pm 4.4^{\circ}\left(\alpha_{95}\right)$ (Fig. F56E) and is within error of the inclination-only mean derived from the piece-average data.

\section{Summary}

Our shipboard measurements suggest that in addition to the volcanic materials recovered, the sedimentary rocks from the uppermost $\sim 40 \mathrm{~m}$ of this hole likely possess paleomagnetic directions that may be used for establishing the magnetic polarity stratigraphy at this site and also for estimating the paleolatitudes at the time of deposition. Although we encountered trouble during stepwise AF demagnetization, as noted above, some samples from limestone and volcanic sandstone indicated linear remanent magnetization components with moderate coercivities $\left(\mathrm{MDF}^{\prime}=10-30 \mathrm{mT}\right)$ and high maximum unblocking temperatures $\left(>500^{\circ} \mathrm{C}\right)$, as shown in Figure F52. These components are not a recently acquired viscous remanent magnetization because they have positive inclination (i.e., reversed polarity in the Southern Hemisphere). However, care needs to be taken when interpreting sedimentary inclinations in determining paleolatitudes because they may have been affected by compaction-induced inclination shallowing. This subject will be addressed by detailed shore-based investigations.

\section{Downhole logging}

Downhole logging measurements obtained from Hole U1376A include natural total and spectral gamma ray, density, neutron porosity, electrical resistivity, electrical images, $P$-wave velocity, and threecomponent magnetic field. An open hole section of $101.9 \mathrm{~m}$ was logged (starting at $80.4 \mathrm{mbsf}$ ) with three tool strings over a period of $\sim 21 \mathrm{~h}$. The borehole remained in good condition throughout logging, and no tight spots were encountered.

\section{Operations}

Downhole logging of Hole U1376A started on 2 February 2011 at $1720 \mathrm{~h}$ (all times are New Zealand Daylight Time, UTC $+13 \mathrm{~h}$ ) after rotary coring ended at a total depth of 182.8 mbsf. For details on hole preparation for logging, see "Operations."

Three tool strings were deployed in Hole U1376A: (1) the triple combination (triple combo), (2) the third-party Göttingen Borehole Magnetometer (GBM), and (3) the Formation MicroScanner (FMS)sonic. The triple combo tool string, which included the Hostile Environment Natural Gamma Ray Sonde (HNGS), Accelerator Porosity Sonde (APS), Hostile Environment Litho-Density Sonde (HLDS), General Purpose Inclinometry Tool (GPIT), and Dual Induction Tool (DIT) (see "Downhole logging" in the "Methods" chapter [Expedition 330 Scientists, 2012a] for tool string details), was lowered into the 
hole at $2323 \mathrm{~h}$ on 2 February. The wireline heave compensator was optimized with the triple combo in open hole at $1675.1 \mathrm{~m}$ wireline log depth below rig floor (WRF). The tool string reached its target depth of $1696.6 \mathrm{~m}$ WRF at $0139 \mathrm{~h}$ on 3 February and began a first uphole pass at $0143 \mathrm{~h}$ (Fig. F57). The tool string was lowered back down for a full repeat pass, which started at $0243 \mathrm{~h}$ (following a 15 min break between measurements in order to allow the formation to equilibrate following neutron activation). This repeat control pass ended when the tool string crossed the seafloor, which was marked by a peak in natural radioactivity clearly visible in the HNGS gamma ray measurement. The seafloor was detected at $1514 \mathrm{~m} \mathrm{WRF}$, which agrees well with the drillers seafloor depth estimate of 1514.3 mbrf. The triple combo was returned to the rig floor and rigged down at $0511 \mathrm{~h}$.

The second tool string deployed in Hole U1376A was the GBM (Fig. F58). The GBM was rigged up and oriented by simultaneously sighting the tool along the ship's long axis while recording the position of two GPS receivers of known location and also the ship's heading using the ship's main gyro (see "Downhole logging" in the "Methods" chapter [Expedition 330 Scientists, 2012a] for details on sighting). The GBM began measuring at $0531 \mathrm{~h}$ and was lowered into the hole at $0554 \mathrm{~h}$ on 3 February. Unfortunately, this run had to be aborted because the drill pipe was stuck in the borehole, and the tool was brought back to the rig floor at $0631 \mathrm{~h}$. The GBM was not rigged down but was held in one of the available storage holes. After the drill pipe was freed and the hole further conditioned, the GBM was rigged back up, sighted, and began taking measurements by $0733 \mathrm{~h}$. The tool string was run into the hole at $0759 \mathrm{~h}$ and reached its target depth of $1696.7 \mathrm{~m} \mathrm{WRF}$ at $0956 \mathrm{~h}$. The GBM ran without error and was returned back to the rig floor, resighted, and rigged down by $1218 \mathrm{~h}$ on 3 February.

The third and final tool string deployed in Hole U1376A was the FMS-sonic combination, which was composed of the HNGS, Dipole Shear Sonic Imager (DSI), GPIT, and FMS (Fig. F59). The FMS-sonic tool string was lowered into the hole at $1338 \mathrm{~h}$ on $3 \mathrm{Feb}-$ ruary and reached the bottom of the hole $(1695.8 \mathrm{~m}$ $\mathrm{WRF}$ ) at $1454 \mathrm{~h}$. The first uphole logging pass started at $1455 \mathrm{~h}$ and ended at $1519 \mathrm{~h}$. After the tool was returned to the bottom of the hole, the second pass started at $1531 \mathrm{~h}$ and ended at $1558 \mathrm{~h}(1475.9 \mathrm{~m}$ WRF) after passing the seafloor at $\sim 1514 \mathrm{~m}$ WRF. Rig down was completed at $1755 \mathrm{~h}$ on 3 February, at which time logging operations in Hole U1376A were completed.

\section{Data processing and quality assessment}

The standard logging data were recorded on board the R/V JOIDES Resolution by Schlumberger and archived in DLIS format. Data were sent via satellite transfer to the Borehole Research Group of the Lamont-Doherty Earth Observatory, processed, and transferred back to the ship for archiving in the shipboard database. Processing and data quality notes are given below. The GBM data were acquired from the tool using GBMlog software and processed with GBM datenverarbeitung software (see "Downhole logging" in the "Methods" chapter [Expedition 330 Scientists, 2012a]).

Depth shifts applied to logging data were performed by selecting a reference (base) log (usually the total gamma ray log from the run with the greatest vertical extent and no sudden changes in cable speed) and by aligning features in equivalent logs from other tool string passes by eye. In the case of Hole $\mathrm{U} 1376 \mathrm{~A}$, the base $\log$ was the gamma ray profile from Pass 1 (main) of the triple combo (HNGSHLDS-GPIT-DIT) tool string. The original logs were first shifted to the seafloor (1514 m WRF), determined by the first clear step in the HNGS gamma ray values.

Proper depth shifting of wireline logging depths relative to core depths was essential to correlate the downhole logging data with all other measurements and observations made on core recovered from Hole U1376A. The seafloor was the only target that offered a potential wireline logging depth reference. However, note that data acquired through the seafloor resulted from logging through the bottom-hole assembly (BHA), so data from this interval are of poor quality and highly attenuated and should only be used qualitatively. However, they are adequate to pick out the seafloor. The quality of wireline logging data was assessed by evaluating whether logged values were reasonable for the lithologies encountered and by checking consistency between different passes of the same tool. Specific details of the depth adjustments required to match logging runs/data are available in the logging processing notes on the log database for Hole U1376A (iodp.ldeo.columbia.edu/DATA/).

A wide $(>30.5 \mathrm{~cm})$ or irregular borehole affects most recordings, particularly by tools like the HLDS (bulk density) that require decentralization and good contact with the borehole wall. The density log correlates well with the resistivity logs but is largely affected by hole conditions. Hole diameter was recorded by the hydraulic caliper on the HLDS tool (LCAL) and by the FMS calipers. Both calipers show a 
mostly "in gauge" borehole with a diameter varying between 24 and $31 \mathrm{~cm}$ and very few enlarged portions. Some small breakouts were observed at $\sim 142$, $\sim 145$, and $\sim 171 \mathrm{~m}$ WRF; however, these were never out of the range of the FMS caliper arms $(40 \mathrm{~cm}$ diameter). Good repeatability was observed between the main and repeat passes of the triple combo and FMS-sonic, particularly for measurements of electrical resistivity, gamma ray, density, and compressional wave velocity $\left(V_{\mathrm{p}}\right)$ (Fig. F60). However, the repeat gamma ray data (obtained with the triple combo) are offset to higher values because the advised 15 min wait time between runs was insufficient to allow activation of the borehole formation (from the neutron source used for porosity measurements in the main run) to sufficiently decay.

Bulk density (HLDS) data were recorded with a sampling rate of 197 measurements per minute $(2.54 \mathrm{~cm}$ at $300 \mathrm{~m} / \mathrm{h})$, in addition to the standard sampling rate of 32 measurements per minute $(15.24 \mathrm{~cm}$ at $300 \mathrm{~m} / \mathrm{h}$ ). The enhanced bulk density curve is the result of the Schlumberger enhanced-processing technique performed on the MAXIS system on board the JOIDES Resolution. In normal processing, shortspaced data are smoothed to match long-spaced data (depth matched and resolution matched). In the enhanced processing, the raw detail obtained from the short-spaced data is added to the standard compensated density (Flaum et al., 1987). In a situation where there is good contact between the HLDS pad and the borehole wall (low density correction), the results are improved because the short spacing has better vertical resolution (i.e., it has the capability to resolve thinner beds/units).

The DSI was operated in the following modes: P\&S monopole and upper dipole for both the downlog and Pass 1 (all with standard frequency). For Pass 2 the DSI was operated in the two above-mentioned modes in addition to Stoneley. The slowness data from DTCO and DT2 (see Table T12 in the "Methods" chapter [Expedition 330 Scientists, 2012a]) are of good quality for these passes and were thus converted to acoustic velocities (VCO and VS2, respectively) (see "Downhole logging" in the "Methods" chapter [Expedition 330 Scientists, 2012a], for a full list of acronyms). Postexpedition reprocessing of the original sonic waveforms is highly recommended to obtain more reliable velocity results.

The FMS images are of excellent quality over the entire hole, and all the images collected downhole in Hole U1376A can be used with confidence. Caliper measurements from the FMS show that the pads should have maintained good contact with the borehole wall.

\section{Preliminary results}

Downhole logging measurements obtained from Hole U1376A include natural total and spectral gamma ray, density, neutron porosity, electrical resistivity, electrical images, compressional velocity, and three-component magnetic field. The results are summarized below.

\section{Electrical resistivity measurements}

Two main electrical resistivity curves were obtained with the DIT: deep induction phasor-processed resistivity (IDPH) and medium induction phasor-processed resistivity (IMPH). The IMPH and IDPH resistivity profiles represent different depths of investigation into the formation $(76$ and $152 \mathrm{~cm}$, respectively) and different vertical resolutions (152 and $213 \mathrm{~cm}$, respectively). The DIT reached the bottom of the logged interval in Hole U1376A because it was the bottommost tool in the logging tool string (Fig. F57). The IDPH measurement is the most reliable for lithologic interpretation because of its deeper investigation depth and hence is less influenced by drilling-induced fractures and the presence of drilling mud cake.

Below $80.4 \mathrm{~m}$ wireline log matched depth below seafloor (WMSF) Hole U1376A is composed of two main petrologically distinct units: a $33 \mathrm{~m}$ thick massive basaltic lava flow (stratigraphic Unit III), which is found down to $\sim 110 \mathrm{~m} \mathrm{WMSF}$, and stratigraphic Unit IV, which is dominated by breccia and interlayered more massive basaltic lava flows and a couple of intrusive sheets or dikes with recovered thicknesses up to $8.96 \mathrm{~m}$. IMPH generally ranges from 3.29 to $579.18 \Omega \mathrm{m}$, and IDPH ranges from 8.0 to $404.8 \Omega \mathrm{m}$ (Fig. F60). Some of the highest resistivity values correlate to more solid layers in the breccia (e.g., at $\sim 145 \mathrm{~m}$ WMSF in stratigraphic Unit IV) and the massive basalt flow unit (stratigraphic Unit III). Both resistivity curves show considerable variability throughout the hole (Fig. F60). However, there is a notable downhole contrast in resistivity, consistent across both resistivity curves, at $\sim 122.5 \mathrm{~m}$ WMSF (log Unit VIII; see "Log units") in stratigraphic Unit IV, which relates to a more visibly conductive (from FMS images) hyaloclastite breccia observed in the recovered core from Hole U1376A.

\section{Gamma ray measurements}

Standard, computed, and individual spectral contributions from ${ }^{40} \mathrm{~K},{ }^{238} \mathrm{U}$, and ${ }^{232} \mathrm{Th}$ were part of the gamma ray measurements obtained in Hole U1376A (Fig. F60) with the HNGS (see Table T12 in the "Methods" chapter [Expedition 330 Scientists, 
2012a]). Downhole open hole gamma ray measurements cover a total of $75.49 \mathrm{~m}$ of the hole. The shorter overall coverage of the HNGS compared with the DIT results from the topmost position of the HNGS in the tool string (Fig. F57).

The lithologic units penetrated and logged in Hole U1376A follow the same low natural gamma ray trend seen in previously measured basaltic crust (e.g., Bartetzko et al., 2001; Barr et al., 2002) (Fig. F61). Total gamma ray (HSGR) values obtained with the HNGS in Hole U1376A range from 10.68 to 29.26 gAPI, with a mean of 18.93 gAPI. Potassium values are relatively low, with values ranging between 0.27 and $0.85 \mathrm{wt} \%$ and a mean of $0.54 \mathrm{wt} \%$ (Fig. F61). This is a much smaller range than that obtained using inductively coupled plasma-atomic emission spectroscopy on core samples (0.47-1.56 $\mathrm{wt} \%$; see "Geochemistry") and is largely explained by the fact that the downhole logging HNGS sonde takes measurements every $15 \mathrm{~cm}$ uphole compared to the very targeted discrete samples used for geochemical analysis (which typically avoid alteration, veins, vesicles, and voids). Uranium values range between 0.0037 and $0.7941 \mathrm{ppm}$ and have a mean of $0.36 \mathrm{ppm}$. In contrast, thorium values are relatively high, ranging from 0.076 to $3.27 \mathrm{ppm}$, with a mean of $1.97 \mathrm{ppm}$. Potassium abundance drives the general downhole correlation seen in total gamma ray, with some greater influence by uranium at 105 and $\sim 145 \mathrm{~m}$ WMSF. Areas of elevated potassium, such as 108-138 m WMSF, relate to the upper portion of stratigraphic Unit IV, where there is a downhole disappearance of augite and the onset of an olivinedominated basaltic section of mostly breccia-in combination with a large quantity of fresh volcanic glass (see "Alteration petrology"). Two coinciding peaks of potassium and uranium at $\sim 105$ and $\sim 145 \mathrm{~m}$ WMSF correlate well to two lava flow units. A peak in uranium at $\sim 112 \mathrm{~m} \mathrm{WMSF}$ is closely associated with the occurrence of the intrusive unit or dike (Fig. F61) of lithologic Unit 20. Finally, comparison of natural gamma radiation measured on whole-round cores with downhole gamma ray data shows good agreement (Fig. F61).

\section{Density}

Density ranges from 2.08 to $3.45 \mathrm{~g} / \mathrm{cm}^{3}$ in Hole U1376A (Fig. F60). A comparison between discrete physical property samples and the downhole density log shows good agreement. Low density values correspond to intervals with larger borehole dimensions and sections that exhibit much higher porosities (Fig. F60). Pronounced high density values relate mostly to intrusive units, lava flows, and a large $33 \mathrm{~m}$ thick massive basalt unit (stratigraphic Unit III) (see log Unit IV, below).

\section{Neutron porosity}

Neutron porosity ranges from $3.99 \%$ to $57.70 \%$, with a mean of $23.09 \%$. Neutron porosity correlates very well (inversely) with density, resistivity, and velocity measurements. Additionally, there is good agreement between moisture and density porosity measurements (see "Physical properties") and downhole logging porosity data (Fig. F60). Overall, moisture and density porosity measurements are slightly lower, but this is because they are biased in the respect that they do not take into account fractures in the formation, whereas downhole measurements provide an overall in situ porosity measurement for the entire formation. A general trend of slightly increasing neutron porosity was observed from $\sim 122$ to $145 \mathrm{~m}$ WMSF. There is a general correlation of lower neutron porosity with higher density, resistivity, and compressional wave velocity $\left(V_{\mathrm{P}}\right)$ (Fig. F60). One main high-porosity zone is clear in Hole U1376A, correlating to a transition to breccia from massive basalt (at the bottom of stratigraphic Unit III) and a change to low density and velocity values.

\section{Elastic wave velocity}

Compressional wave velocity $\left(V_{\mathrm{P}}\right)$ ranges from 2.88 to $6.89 \mathrm{~km} / \mathrm{s}$, with trends in the data correlating well with discrete physical property measurements (Fig. F60). There is a clear relationship between $V_{\mathrm{P}}$ and density, porosity, and resistivity, with $V_{\mathrm{p}}$ being higher where resistivity and density are higher and porosity is lower. Peaks in $V_{\mathrm{P}}$ can be related to the large section of massive basaltic lava in stratigraphic Unit III and lava/intrusive units found in the breccia sequences (stratigraphic Unit IV). The lowest $V_{\mathrm{P}}$ values can be related to large fracture zones in the massive basalt and within the brecciated units. Compressional wave velocity measured on discrete samples taken from the core correlates well with downhole logging data. It should be noted that velocity values obtained by downhole logging give an overall value for the formation measured, including fractures and clast and matrix mixtures, and are therefore generally lower.

\section{Magnetic field measurements}

Two different tools were used to obtain magnetic field data in Hole U1376A. The GPIT was run as part of the FMS-sonic tool string, whereas the GBM was run on its own dedicated tool string. Magnetic field data in the drill pipe were only collected by the GBM and were heavily affected by the magnetized pipe, which saturated the magnetometers.

\section{Borehole deviations}

Both the GPIT and the GBM measure the deviation of the borehole from vertical, and the results of these 
measurements are shown in Figure F62. The deviation differs slightly between the tool strings because of their different lengths and geometries. The mean deviations from vertical measured by the GBM and GPIT are $3.83^{\circ} \pm 0.44^{\circ}$ and $4.38^{\circ} \pm 0.26^{\circ}$, respectively, and are within error.

The approximate value for the borehole azimuth in Hole U1376A is $92^{\circ} \pm 2^{\circ}$. This value is determined by the GPIT using magnetic field measurements. However, these values are influenced by the magnetic/ magnetized neighboring components on the sonde's associated tool string, and thus this value for azimuth and its uncertainty are only preliminary.

\section{Magnetic measurements}

The magnetic logs of the GPIT and GBM show the same trend in the formation. Raw magnetic field data of the different tools are shown in Figures F63 and F64. These data were corrected for all sensor errors (sensor offsets, scale factors, and errors in orthogonality) but not for the deviation from vertical of the tool string of $\sim 4^{\circ}$ (see above). This means that the shown horizontal and vertical fields are not yet entirely aligned to the Earth's reference frame. The horizontal magnetic components measured by the two instruments show only small differences, but the vertical components have noticeably different offsets. This is mainly caused by the influence of magnetized components above the GPIT magnetometers in the FMS-sonic tool string (Fig. F59).

To reduce the magnetic influence of the tool string on the magnetometers of the GBM, a nonmagnetic aluminum sinker bar was custom-made for this expedition and run directly above the tool (Fig. F58). Thus, the magnetic field data measured with the GBM are more reliable and cleaner than those obtained with the GPIT. The influence of the Schlumberger sinker bar and the centralizer was found to be on the order of $350 \mathrm{nT}$ (total field) during extensive testing done in Houston, Texas (USA), in August 2010. The aluminum sinker bar lowers this influence to $<50 \mathrm{nT}$ by almost doubling the distance between the magnetometer and the magnetized/magnetizable parts of the tool string. In the case of the GPIT, the surrounding magnetized parts of the associated tool string have an influence on the inclination of the magnetic field measured by this sonde (Fig. F65). The actual magnetic field inclination in the borehole should be steeper than the average magnetic field inclination given by the GPIT. We expect that a more accurate inclination will be derived from the GBM data postexpedition.

\section{Determination of rotation history: fiber-optic gyros}

In addition to the fluxgate sensors, three angular rate sensors measured the rotations of the GBM. These data will be used to reorient the recorded magnetic field to the Earth's reference frame. Figure F66 shows the accumulated rotation angle for all gyros during the GBM run. The data are not yet corrected for the rotation of the Earth. Nevertheless, the $\mathrm{Rz}$ gyro already provides an approximate rotation history about the vertical axis of the tool. The tool turned $\sim 25$ times counterclockwise during the downlog and 8 times clockwise during the uplog. In the open hole, the tool hardly rotated at all (a total of $\sim 1$ turn). The low rates of rotation in the open hole are likely caused by the stabilizing effect of the drilling mud and the rougher surface of the open hole.

Figure F67 shows the raw magnetic data from the GBM run together with the lithology from the core recovered from Hole U1376A. The GBM does not record data against depth, but both magnetic field and depth were recorded against time, allowing the data to be combined. The log was depth shifted to the approximate core depth but has not yet been matched to the other downhole logs.

The drill pipe extends to 80.4 mbsf. Its magnetic influence decays within $\sim 10 \mathrm{~m}$ below the pipe and mostly affects the vertical component. Because of the way the hole is prepared for logging, a drill bit is present at the bottom of the hole; hence, both the horizontal and vertical components are disturbed at the lower end of the logs for approximately the bottommost $5 \mathrm{~m}$. Remarkably, the thick augite-phyric lava flow in stratigraphic Unit III is not as homogeneous in the GBM data as in the other logging data (Fig. F60) or the physical property and paleomagnetic data collected on the cores (see "Physical properties" and "Paleomagnetism"). Nevertheless, the magnetic data (particularly the vertical component) have an anomaly at $\sim 105$ mbsf that appears to coincide with the breccia recovered at the base of lithologic Unit 15. These findings will be further examined postexpedition. In addition, Cores 330U1376A-17R and 18R had low recovery (42\% and $9 \%$, respectively), and the magnetic data over this interval show large variations on the order of 2000 $\mathrm{nT}$, which will also be investigated in more detail postexpedition. The section between 112 and 130 mbsf is very homogeneous in the vertical field, with only two sharp peaks.

Further detailed investigations of the data collected with the GBM will focus on separating and identify- 
ing the magnetic signals of the different flow units and determining the inclination and declination of the natural remanent magnetization, with the intention of estimating the virtual geomagnetic pole position and the paleolatitude of the Louisville hotspot.

\section{Log units}

Preliminary interpretation of the downhole log data divided Hole U1376A into a number of log units (Fig. F60). Log units in the section covered or partially influenced by the BHA were interpreted on the basis of downhole gamma ray, whereas log units in the open hole section were characterized using the resistivity, density, porosity, and compressional wave velocity logs.

Three log units were qualitatively identified in the section covered by the BHA (Fig. F60):

- Log Unit I (seafloor to $26 \mathrm{~m}$ WMSF) shows a significant increase in total gamma ray measurements.

- Log Unit II ( 26-40 m WMSF) shows a steep decline to extremely low gamma ray values. This $\log$ unit correlates well to stratigraphic Subunit IIA, an algal limestone formation.

- Log Unit III ( 40-80.4 m WMSF) shows slightly higher gamma ray values compared to log Unit II. This depth range correlates to a section of conglomerates, volcanic breccia, and the top of the main massive basaltic lava unit. This log unit extends to the end of the drill pipe, where one can see how attenuated the signal is (as it moves through a petrologically similar unit) compared to the open hole section.

The sequence in open hole below the BHA was divided into 10 additional log units (Fig. F60):

- Log Unit IV (80.4-104 m WMSF) has consistently high values for density, resistivity, porosity, and velocity, related to a massive basalt lava unit in stratigraphic Unit III. Lower values of density, resistivity, and velocity with higher porosity values correlate to significant conductive fractures in the basalt unit (which can be seen in FMS images).

- Log Unit V (104-108 m WMSF) exhibits significantly lower values of density and velocity, moderate resistivity, and higher porosity and gamma ray values compared with the previous log unit. Log Unit V relates to a relatively narrow band of breccia found toward the base of stratigraphic Unit III. The GBM data sharply increase in both the vertical and horizontal field in the transition to the brecciated zone.

- Log Unit VI (108-109.5 m WMSF) shows increases in density and velocity values and decreases in natural gamma ray and porosity. Additionally, the GBM data show a prominent decrease in the magnetic field in the vertical component. This correlates to the lowermost basalt lava unit at the very base of stratigraphic Unit III.

- Log Unit VII (109.5-123 m WMSF) exhibits some small stepped increases in resistivity. Density increases very slightly downhole in this unit and porosity decreases, whereas velocity remains fairly constant. A small peak in density, resistivity, and velocity at the top of this log unit relates to lithologic Unit 18 (an intrusion). The overall trend in the data relates to the breccia unit at the top of stratigraphic Unit IV.

- Log Unit VIII (123-145 m WMSF) exhibits some of the lowest density, resistivity, gamma ray, and velocity measured in the open hole in Hole U1376A. This log unit primarily correlates to a portion of the hole with poor core recovery ( 130-144 mbsf). The aphyric basalt unit at $\sim 128$ mbsf is visible in the logging data by a small peak in density, resistivity, and velocity and a small trough in porosity. The log unit shows the section to be variable and correlate to interlayered massive and brecciated units. Overall, porosity steadily increases throughout this log unit to the maximum observed in Hole U1376A.

- Log Unit IX (145-147 m WMSF) has high gamma ray, density, resistivity, and velocity and low porosity. In addition, the GBM data show a decrease in the vertical component of the magnetic field and an increase in the horizontal component of the magnetic field. This log unit correlates directly to a massive olivine-phyric basalt unit in stratigraphic Unit IV.

- Log Unit X (147-158 m WMSF) has overall higher values of density and resistivity than those in log Unit VIII. There is considerable variability in the velocity data and an overall decreasing trend in porosity.

- Log Unit XI (158-160 m WMSF) exhibits high density, resistivity, and velocity and low porosity, which correlates to a massive olivine-phyric basalt unit in stratigraphic Unit IV.

- Log Unit XII ( 160-163 m WMSF) is differentiated using only density, resistivity, porosity, and velocity. This log unit exhibits a significant decrease in density, resistivity, and velocity and an associated increase in porosity, which correlates well with a band of heterolithic breccia in stratigraphic Unit IV.

- Log Unit XIII (163-168 m WMSF) was defined using only density and resistivity. This log unit exhibits higher density and resistivity values and 
correlates very well to two massive aphyric basalt units in stratigraphic Unit IV.

Beneath log Unit XIII only resistivity data are available. Values for resistivity are high immediately beneath log Unit XIII and correspond to the top of lithologic Unit 41, a dike intrusion of aphyric basalt.

\section{Electrical and acoustic images}

In Hole U1376A, we also acquired FMS electrical resistivity images (Figs. F68, F69, F70). The quality of electrical resistivity image measurements depends on close contact between the measuring pads on the tool and the borehole wall. The FMS borehole images collected in Hole U1376A are of very high quality owing to the borehole being in gauge throughout the logged section.

The greatest utility of FMS imagery comes when recovery is low. In Hole U1376A core recovery between $\sim 130$ and 144 mbsf was very poor. Using FMS imagery and other standard log data, we can make a competent attempt at filling the data gap in order to have a continuous record downhole. Figure F68 shows FMS images over the entire unrecovered section. It is not possible to determine the petrology of the lithology, but the structural makeup is clear. Toward the top of the unrecovered section (130-131 m WMSF) there appears to be a solid banded unit with a concentrated band of vesicles toward its base (Fig. F68B). Beneath this potential flow, the formation appears very blocky (131-133 m WMSF) (Fig. F68C) with some angular blocks $\sim 50 \mathrm{~cm}$ long. A portion of very conductive and brecciated material beneath occurs down to $\sim 136 \mathrm{~m}$ WMSF, where a highly resistive band of a possible lava lobe (Fig. F68D) is present. Toward the base of the unrecovered section there is a $2 \mathrm{~m}$ interval of more resistive brecciated material, followed by a more conductive, resistive-clast-sparse breccia (Fig. F68E). Overall, the formation in this unrecovered section is variable and appears to contain a large amount of conductive sections, which most likely relate to more porous, brecciated materials interlayered with more resistive, massive basalt layers or lava lobes.

The FMS images also highlight some of the key features observed in the core recovered from Hole U1376A (Fig. F69), including massive flow units, intrusive contacts, and smaller features such as clasts and vesicles. Additionally, the FMS images help refine lithologic boundaries when contacts are not recovered in the core. Another strength of FMS imagery is the fact that the images are oriented to geographic north (using the GPIT), and by picking sinusoidal traces on the images one can obtain important oriented structural information on key boundaries, fractures, and other features of interest
(Fig. F70). It is possible to differentiate between picked fractures (be they conductive or resistive) and bed boundaries. Extensive structural picking is a key part of postexpedition research. Figure F70 shows some provisional sinusoid picks that highlight some of the true dips and azimuths observed in a number of the stratigraphic and lithologic units. From these preliminary picks one can obtain a true dip for the top surface of lithologic Unit 41 (an intrusion) of $34.5^{\circ}$ and a true azimuth of $140.3^{\circ}$ (Fig. F70D; note that at this surface the hole deviation is $4^{\circ}$ toward $94.1^{\circ}$ and has been corrected for hole deviation). Additionally, we observe variable conductive fracture dips and orientations in the massive basalt unit (Fig. F70A; from top to bottom: true dip $46.3^{\circ}$ toward true azimuth $289.4^{\circ}, 43.8^{\circ}$ toward $334.6^{\circ}, 46.3^{\circ}$ toward $55.8^{\circ}, 63.4^{\circ}$ toward $279.9^{\circ}, 46.2^{\circ}$ toward $246.2^{\circ}$, and $13.1^{\circ}$ toward $320.2^{\circ}$ ). Such structural picks can aid overall interpretation of the lithologic sequence observed in the core and be used to produce a stress regime model for the drilled formation.

\section{Microbiology}

The goals of microbiology sampling at Site U1376 were to collect samples for shore-based cell counts, molecular biological analyses, and $\delta^{34} \mathrm{~S}$ and $\delta^{13} \mathrm{C}$ stable isotope analyses; to inoculate media for cultivation of subseafloor microbes; and to set up stable isotope addition bioassays whereby the rate of incorporation of compounds labeled with ${ }^{14} \mathrm{C},{ }^{15} \mathrm{~N}$, and ${ }^{34} \mathrm{~S}$ can be measured. Such bioassays will allow for calculation of metabolic rates of subseafloor microbes at Burton Guyot. Eleven whole-round samples (5-13 cm long) were collected for microbiological analysis (Figs. F71, F72). The samples were volcanic sandstone (two), limestone (boundstone) (two), volcanic breccia (three), and basaltic lava flows (four). All samples were preserved for shorebased DNA analysis, cell counting, and $\delta^{34} \mathrm{~S}$ and $\delta^{13} \mathrm{C}$ analyses. Five samples were used to inoculate 70 culturing experiments with as many as 10 different types of cultivation media (Table T15). Two samples were used to set up stable isotope addition bioassays to determine rates of carbon and nitrogen utilization by subsurface microbes at Burton Guyot (Table T16). One core was seeded with fluorescent microspheres, and samples from this core were collected for shipboard analysis of contamination via fluorescent microsphere counts.

\section{Cell counts}

Performing shipboard cell counts on rock samples is difficult or nearly impossible because of the combination of autofluorescence from rock particles and 
the difficulty of focusing using a $100 \times$ objective paired with a $10 \times$ eyepiece $(1000 \times$ total magnification) on a moving ship. Therefore, cell counts were not attempted on samples from Site U1376.

\section{Culturing experiments}

Five samples were used to inoculate 70 culturing experiments with as many as 10 different types of cultivation media targeting autotrophic sulfur oxidizers, heterotrophic sulfur oxidizers, autotrophic iron oxidizers, autotrophic iron reducers, heterotrophic iron reducers, heterotrophic sulfate-reducing bacteria, and nonspecific heterotrophs (Table T15; for details on media recipes, see Table T14 in the "Methods" chapter [Expedition 330 Scientists, 2012a]). On the basis of visual observation of turbidity, $43 \%$ of the vials had obvious growth in them. Media targeting sulfur-oxidizing bacteria and general heterotrophic bacteria were the most successful. The highest proportion of inoculated vials with positive growth are from Sample 330-U1376A-2R-3, 0-6 cm, a volcanic sandstone, and Sample 17R-2, 112-120 cm, an aphyric basalt. The deepest depth from which positive results were obtained is 174 mbsf (Sample 330U1376A-23R-1, 102-114 cm). All preliminary results will be verified during shore-based research.

\section{Stable isotope addition bioassays}

Two samples were used to initiate stable isotope addition bioassays to study rates of carbon, nitrogen, and sulfur cycling by subsurface microbes at Burton Guyot (Table T16). Enhanced extraction (see "Microbiology" in the "Methods" chapter [Expedition 330 Scientists, 2012a]) was carried out on both samples.

For both samples, $2.71 \mathrm{mM}{ }^{13} \mathrm{C}$ bicarbonate, $300 \mu \mathrm{M}$ ${ }^{34} \mathrm{~S}$ elemental sulfur, and $0.5 \mu \mathrm{M}{ }^{15} \mathrm{~N}$ ammonia were added to the bioassays (Table T16). Both bioassays include "killed" control vials. These vials were treated in the same way as the other experimental vials, with the exception that after the rock chips were added the vials were combusted at $>400^{\circ} \mathrm{C}$ for $3 \mathrm{~h}$ to kill all microbes. After the vials were cooled to room temperature, basic seawater media (see "Microbiology" in the "Site U1373" chapter [Expedition 330 Scientists, 2012c]) and stable isotopes were added to the vials; from that point on the killed vials were treated in the same way as the other ("live") vials. This kill treatment acts as a negative control and provides a baseline stable isotope reading for the rocks in the experiment. One vial will be terminated at $t_{2}$ (2 months; Sample 330-U1376A-7R-3, 59-71 cm, only) and the other will be terminated at $t_{3}$ (6 months; both samples).
As with the stable isotope addition bioassays performed at Sites U1373 and U1374, stable isotopes and rock chips were added to $125 \mathrm{~mL}$ serum vials, followed by $100 \mathrm{~mL}$ of basic seawater media. The vials were then placed in a $4^{\circ} \mathrm{C}$ incubator in the dark. At time points of 2 weeks $\left(t_{1}\right), 2$ months $\left(t_{2}\right)$, and 6 months $\left(t_{3}\right)$, the incubation in one or more vials (depending on number of vials per condition) will be terminated, and the rocks will be collected to measure incorporation of labeled carbon, nitrogen, and sulfur.

\section{Contamination testing}

Fluorescent microspheres were deployed during drilling for Core 330-U1376A-19R. A small amount of drill fluid was collected from inside the core liner when the microbiology whole-round sample was selected. Analysis of this drill fluid should provide the concentration of microspheres delivered to the core. Water samples for microsphere counts were also collected from each of the three separate sterile seawater rinses that every microbiology whole-round sample was subjected to before subsampling. For each wash, $50 \mathrm{~mL}$ of sterile seawater was used. After the microbiology whole round was washed, two subsamples were taken from the outside of the whole round and two were collected from the inside of the whole-round sample during standard microbiology sampling. These were preserved the same way as cell count samples and were analyzed via fluorescent microscopy to quantify microspheres in the rocks.

Shipboard counts of fluorescent microspheres revealed $1.2 \times 10^{4}$ microspheres per milliliter of drill fluid. Microsphere counts of the rinse water were negative for the first two rinses, and there was one clump of three microspheres in the third wash. No microspheres were detected on the outside or inside of the whole-round samples. The absence of any microspheres on or inside the whole-round samples indicates that the potential for microbial contamination was low during drilling of Hole U1376A.

\section{References}

Alt, J.C., 1995. Subseafloor processes in mid-ocean ridge hydrothermal systems. In Humphris, S.E., Zierenberg, R., Mullineaux, L., and Thomson, R. (Eds.), Seafloor Hydrothermal Systems: Physical, Chemical, Biological and Geological Interactions within Hydrothermal Systems. Geophys. Monogr., 91:85-114.

Alt, J.C., and Teagle, D.A.H., 2003. Hydrothermal alteration of upper oceanic crust formed at a fast-spreading ridge: mineral, chemical, and isotopic evidence from ODP Site 801. Chem. Geol., 201(3-4):191-211.

doi:10.1016/S0009-2541(03)00201-8 
Arason, P., and Levi, S., 2010. Maximum likelihood solution for inclination-only data in paleomagnetism. Geophys. J. Int., 182(2):753-771. doi:10.1111/j.1365246X.2010.04671.X

Bach, W., Hegner, E., Erzinger, J., and Satir, M., 1994. Chemical and isotopic variations along the superfast spreading East Pacific Rise from 6 to $30^{\circ} \mathrm{S}$. Contrib. Mineral. Petrol., 116(4):365-380. doi:10.1007/BF00310905

Barr, S.R., Révillon, S., Brewer, T.S., Harvey, P.K., and Tarney, J., 2002. Determining the inputs to the Mariana Subduction Factory: using core-log integration to reconstruct basement lithology at ODP Hole 801C. Geochem., Geophys., Geosyst., 3(11):8901-8925. doi:10.1029/ 2001GC000255

Bartetzko, A., Pezard, P., Goldberg, D., Sun, Y.-F., and Becker, K., 2001. Volcanic stratigraphy of DSDP/ODP Hole 395A: an interpretation using well-logging data. Mar. Geophys. Res., 22(2):111-127. doi:10.1023/ A:1010359128574

Beier, C., Vanderkluysen, L., Regelous, M., Mahoney, J.J., and Garbe-Schönberg, D., 2011. Lithospheric control on geochemical composition along the Louisville Seamount Chain. Geochem., Geophys., Geosyst., 12:Q0AM01. doi:10.1029/2011GC003690

Burns, S.J., Baker, P.A., and Elderfield, H., 1992. Timing of carbonate mineral precipitation and fluid flow in seafloor basalts, northwest Indian Ocean. Geology, 20(3):255-258. doi:10.1130/ 0091-7613(1992)020<0255:TOCMPA > 2.3.CO;2

Chadwick, W.W., Jr., Geist, D.J., Jónsson, S., Poland, M., Johnson, D.J., and Meertens, C.M., 2006. A volcano bursting at the seams: inflation, faulting, and eruption at Sierra Negra Volcano, Galápagos. Geology, 34(12):1025-1028. doi:10.1130/G22826A.1

Cheng, Q., Park, K.-H., Macdougal, J.D., Zindler, A., Lugmair, G.W., Hawkins, J., Lonsdale, P., and Staudigel, H., 1987. Isotopic evidence for a hot spot origin of the Louisville Seamount Chain. In Keating, B.H., Fryer, P., Batiza, R., and Boehlert, G. (Eds.), Seamounts, Islands and Atolls. Geophys. Monogr., 43:283-296.

Clague, D.A., Moore, J.G., Dixon, J.E., and Friesen W.B., 1995. Petrology of submarine lavas from Kilauea's Puna Ridge, Hawaii. J. Petrol., 36(2):299-349.

Courtillot, V., Davaille, A., Besse, J., and Stock, J., 2003. Three distinct types of hotspots in Earth's mantle. Earth Planet. Sci. Lett., 205(3-4):295-308. doi:10.1016/S0012821X(02)01048-8

Duncan, R.A., Tarduno, J.A., and Scholl, D.W., 2006. Leg 197 synthesis: southward motion and geochemical variability of the Hawaiian hotspot. In Duncan, R.A., Tarduno, J.A., Davies, T.A., and Scholl, D.W. (Eds.), Proc. ODP, Sci. Results, 197: College Station, TX (Ocean Drilling Program), 1-39. doi:10.2973/ odp.proc.sr.197.001.2006

Expedition 330 Scientists, 2012a. Methods. In Koppers, A.A.P., Yamazaki, T., Geldmacher, J., and the Expedition 330 Scientists, Proc. IODP, 330: Tokyo (Integrated Ocean
Drilling Program Management International, Inc.). doi:10.2204/iodp.proc.330.102.2012

Expedition 330 Scientists, 2012b. Site U1372. In Koppers, A.A.P., Yamazaki, T., Geldmacher, J., and the Expedition 330 Scientists, Proc. IODP, 330: Tokyo (Integrated Ocean Drilling Program Management International, Inc.). doi:10.2204/iodp.proc.330.103.2012

Expedition 330 Scientists, 2012c. Site U1373. In Koppers, A.A.P., Yamazaki, T., Geldmacher, J., and the Expedition 330 Scientists, Proc. IODP, 330: Tokyo (Integrated Ocean Drilling Program Management International, Inc.). doi:10.2204/iodp.proc.330.104.2012

Expedition 330 Scientists, 2012d. Site U1375. In Koppers, A.A.P., Yamazaki, T., Geldmacher, J., and the Expedition 330 Scientists, Proc. IODP, 330: Tokyo (Integrated Ocean Drilling Program Management International, Inc.). doi:10.2204/iodp.proc.330.106.2012

Fitton, J.G., and Godard, M., 2004. Origin and evolution of magmas on the Ontong Java Plateau. In Fitton, J.G., Mahoney, J.J., Wallace, P.J., and Saunders, A.D. (Eds.), Origin and Evolution of the Ontong Java Plateau. Geol. Soc. Spec. Publ., 229(1):151-178. doi:10.1144/

GSL.SP.2004.229.01.10

Flaum, C., Galford, J.E., and Hastings, A., 1987. Enhanced vertical resolution processing of dual detector gammagamma density logs. Trans. SPWLA Annu. Logging Symp., 28.

Flügel, E., 1982. Microfacies Analysis of Limestones: New York (Springer-Verlag).

Frey, F.A., Garcia, M.O., Wise, W.S., Kennedy, A., Gurriet, P., and Albarede, F., 1991. The evolution of Mauna Kea Volcano, Hawaii: petrogenesis of tholeiitic and alkalic basalts. J. Geophys. Res., [Solid Earth], 96(B9):1434714375. doi:10.1029/91JB00940

Frey, F.A., Wise, W.S., Garcia, M.O., West, H., Kwon, S.-T., and Kennedy, A., 1990. Evolution of Mauna Kea Volcano, Hawaii: petrologic and geochemical constraints on postshield volcanism. J. Geophys. Res., [Solid Earth], 95(B2):1271-1300. doi:10.1029/JB095iB02p01271

Garcia, M.O., Pietruszka, A.J., and Rhodes, J.M, 2003. A petrologic perspective of Kilauea Volcano's summit magma reservoir. J. Petrol., 44(12):2313-2339. doi:10.1093/petrology/egg079

Hawkins, J.W., Lonsdale, P., and Batiza, R., 1987. Petrologic evolution of the Louisville Seamount Chain. In Keating, B.H., Fryer, P., Batiza, R., and Boehlert, G.W. (Eds.), Seamounts, Islands, and Atolls. Geophys. Monogr., 43:235254.

Jelinek, V., 1981. Characterization of the magnetic fabric of rocks. Tectonophysics, 79(3-4):T63-T67. doi:10.1016/ 0040-1951(81)90110-4

Koppers, A.A.P., Duncan, R.A., and Steinberger, B., 2004. Implications of a nonlinear ${ }^{40} \mathrm{Ar} /{ }^{39} \mathrm{Ar}$ age progression along the Louisville Seamount Trail for models of fixed and moving hot spots. Geochem., Geophys., Geosyst., 5(6):Q06L02-Q06L23. doi:10.1029/2003GC000671 
Koppers, A.A.P., Yamazaki, T., and Geldmacher, J., 2010. Louisville Seamount Trail: implications for geodynamic mantle flow models and the geochemical evolution of primary hotspots. IODP Sci. Prosp., 330. doi:10.2204/ iodp.sp.330.2010

Le Maitre, R.W., Bateman, P., Dudek, A., Keller, J., Lameyre, J., Le Bas, M.J., Sabine, P.A., Schmid, R., Sorensen, H., Streckeisen, A., Woolley, A.R., and Zanettin, B., 1989. A Classification of Igneous Rocks and Glossary of Terms: Oxford (Blackwell).

Lipman, P.W., Rhodes, J.M., and Dalrymple, G.B., 1990. The Ninole basalt-implications for the structural evolution of Mauna Loa Volcano, Hawaii. Bull. Volcanol., 53(1):1-19. doi:10.1007/BF00680316

Macdonald, G.A., 1968. Composition and origin of Hawaiian lavas. In Coats, R.R., Hay, R.L., and Anderson, C.A. (Eds.), Studies in Volcanology-A Memoir in Honor of Howel Williams. Mem.-Geol. Soc. Am., 116:477-522.

Macdonald, G.A., and Katsura, T., 1964. Chemical composition of Hawaiian lavas. J. Petrol., 5(1):82-133. http:// petrology.oxfordjournals.org/content/5/1/ 82.abstract

Mahoney, J.J., Sinton, J.M., Kurz, M.D., Macdougall, J.D., Spencer, K.J., and Lugmair, G.W., 1994. Isotope and trace element characteristics of a super-fast spreading ridge: East Pacific Rise $13-23^{\circ}$ S. Earth Planet. Sci. Lett., 121(1-2):173-193. doi:10.1016/ 0012-821X(94)90039-6

Moore, J.G., and Clague, D.A., 1992. Volcano growth and evolution of the island of Hawaii. Geol. Soc. Am. Bull., 104(11):1471-1484. doi:10.1130/ 0016-7606(1992)104<1471:VGAEOT>2.3.CO;2

Perch-Nielsen, K., 1985. Cenozoic calcareous nannofossils. In Bolli, H.M., Saunders, J.B., and Perch-Nielsen, K. (Eds.), Plankton Stratigraphy: Cambridge (Cambridge Univ. Press), 427-554.

Ramsay, J.G., and Huber, M.I., 1987. The Techniques of Modern Structural Geology (Vol. 2): Folds and Fractures: New York (Acad. Press).

Rhodes, J.M., 1996. Geochemical stratigraphy of lava flows sampled by the Hawaii Scientific Drilling Project. J. Geophys. Res., [Solid Earth], 101(B5):11729-11746. doi:10.1029/95JB03704

Rhodes, J.M., and Hart, S.R., 1995. Episodic trace element and isotopic variations in historical Mauna Loa lavas: implications for magma and plume dynamics. In Rhodes, J.M., and Lockwood, J.P. (Eds.), Mauna Loa Revealed: Structure, Composition, History, and Hazards. Geophys. Monogr., 92:263-288.

Sinton, J.M., Smaglik, S.M., Mahoney, J.J., and Macdonald, K.C., 1991. Magmatic processes at superfast spreading mid-ocean ridges: glass compositional variations along the East Pacific Rise $13^{\circ}-23^{\circ} \mathrm{S}$. J. Geophys. Res., [Solid Earth], 96:6133-6155. doi:10.1029/90JB02454

Smith, G.A., and Lowe, D.R., 1991. Lahars: volcano-hydrologic events and deposition in the debris flow-hyperconcentrated flow continuum. In Fisher, R.V., and Smith, G.A. (Eds), Sedimentation in Volcanic Settings.
Spec. Publ._SEPM (Soc. Sediment. Geol.), 45:59-70. doi:10.2110/pec.91.45.0059

Smith, W.H.F., and Sandwell, D.T., 1997. Global sea floor topography from satellite altimetry and ship depth soundings. Science, 277(5334):1956-1962. doi:10.1126/ science.277.5334.1956

Stanley, S.M., and Hardie, L.A., 1998. Secular oscillations in the carbonate mineralogy of reef-building and sediment-producing organisms driven by tectonically forced shifts in seawater chemistry. Palaeogeogr., Palaeoclimatol., Palaeoecol., 144(1-2):3-19. doi:10.1016/ S0031-0182(98)00109-6

Steinberger, B., 2002. Motion of the Easter hot spot relative to Hawaii and Louisville hot spots. Geochem., Geophys., Geosyst., 3(11):8503-8529. doi:10.1029/ 2002GC000334

Steinberger, B., and Antretter, M., 2006. Conduit diameter and buoyant rising speed of mantle plumes: implications for the motion of hot spots and shape of plume conduits. Geochem., Geophys., Geosyst., 7(11):Q11018Q11042. doi:10.1029/2006GC001409

Steinberger, B., and Calderwood, A., 2006. Models of largescale viscous flow in the Earth's mantle with constraints from mineral physics and surface observations. Geophys. J. Int., 167(3):1461-1481. doi:10.1111/j.1365246X.2006.03131.X

Steinberger, B., Sutherland, R., and O'Connell, R.J., 2004. Prediction of Emperor-Hawaii Seamount locations from a revised model of global plate motion and mantle flow. Nature (London, U. K.), 430(6996):167-173. doi:10.1038/nature02660

Tarduno, J.A., Duncan, R.A., Scholl, D.W., Cottrell, R.D., Steinberger, B., Thordarson, T., Kerr, B.C., Neal, C.R., Frey, F.A., Torii, M., and Carvallo, C., 2003. The Emperor Seamounts: southward motion of the Hawaiian hotspot plume in Earth's mantle. Science, 301(5636):1064-1069. doi:10.1126/science.1086442

Tarduno, J.A., Duncan, R.A., Scholl, D.W., et al., 2002. Proc. ODP, Init. Repts., 197: College Station, TX (Ocean Drilling Program). doi:10.2973/odp.proc.ir.197.2002

Tejada, M.L.G., Mahoney, J.J., Duncan, R.A., and Hawkins, M.P., 1996. Age and geochemistry of basement and alkalic rocks of Malaita and Santa Isabel, Solomon Islands, southern margin of Ontong Java Plateau. J. Petrol., 37(2):361-394. doi:10.1093/petrology/37.2.361

Tejada, M.L.G., Mahoney, J.J., Neal, C.R., Duncan, R.A., and Petterson, M.G., 2002. Basement geochemistry and geochronology of central Malaita, Solomon Islands, with implications for the origin and evolution of the Ontong Java Plateau. J. Petrol., 43(3):449-484. doi:10.1093/petrology/43.3.449

Vanderkluysen, L., Mahoney, J.J., Koppers, A.A., and Lonsdale, P.F., 2007. Geochemical evolution of the Louisville Seamount Chain. Eos, Trans. Am. Geophys. Union, 88(52)(Suppl.):V42B-06. http://www.agu.org/meetings/fm07/waisfm07.html

Wessel, P., and Kroenke, L.W., 1997. A geometric technique for relocating hotspots and refining absolute plate 
motions. Nature (London, U. K.), 387(6631):365-369. doi:10.1038/387365a0

West, H.B., Garcia, M.O., Frey, F.A., and Kennedy, A., 1988. Nature and cause of compositional variation among the alkalic cap lavas of Mauna Kea Volcano, Hawaii. Contrib.
Mineral. Petrol., 100(3):383-397. doi:10.1007/ BF00379747

Publication: 11 February 2012 MS 330-107 
Figure F1. Bathymetric map of the Louisville Seamount Trail in the Southwest Pacific, showing the location of Site U1375 on Achernar Guyot and Site U1376 on Burton Guyot. GMT-generated bathymetric map is based on a combination of SIMRAD EM120 multibeam data collected during the AMAT02RR site survey expedition aboard the R/V Roger Revelle and global predicted bathymetry (v8.2) from Smith and Sandwell (1997). The current motion of the Pacific plate is indicated with the black arrow. The map uses a linear projection (i.e., vertical and horizontal scales differ) based on WGS-84.

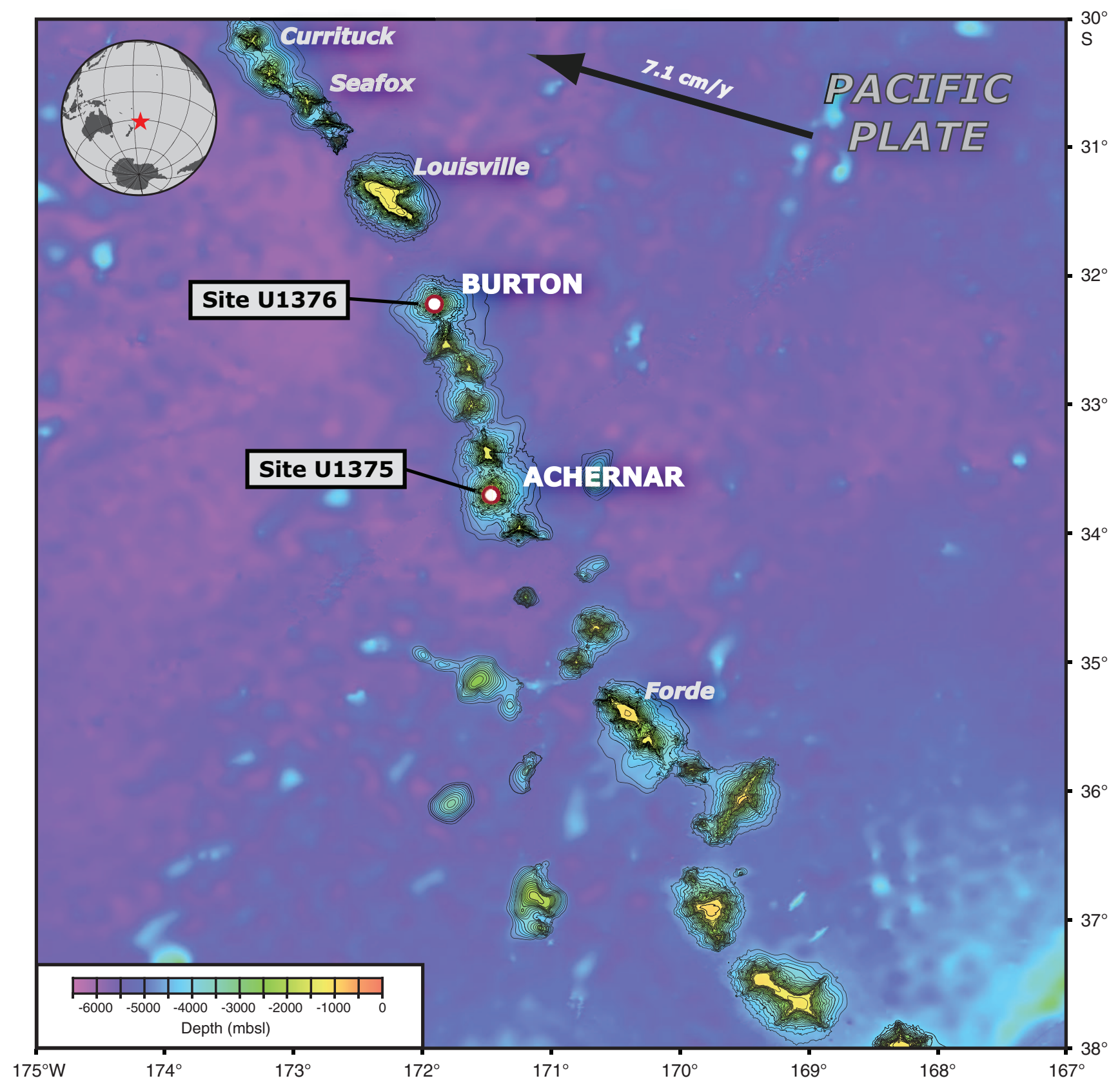


Figure F2. Detailed bathymetric map of Site U1376 on Burton Guyot. GMT-generated bathymetric map is based on SIMRAD EM120 multibeam data collected during the AMAT02RR site survey expedition aboard the R/V Roger Revelle and global predicted bathymetry (v8.2) from Smith and Sandwell (1997). Crossing multichannel seismic reflection lines collected during the AMAT02RR site survey are shown in blue (for details, see Koppers et al., 2010). Map uses a linear projection (i.e., vertical and horizontal scales differ) based on WGS-84.

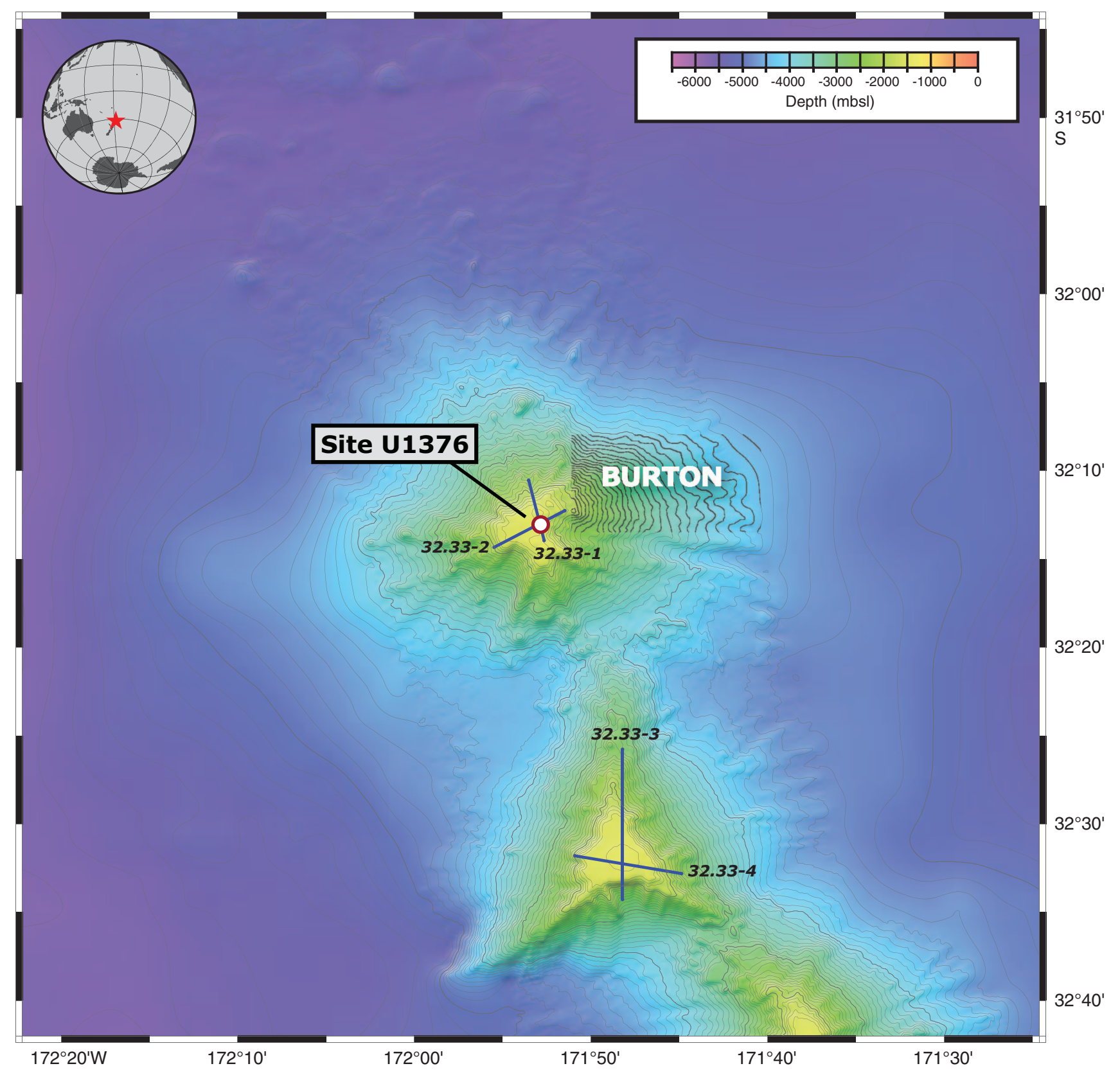


Figure F3. Operation time vs. penetration depth, Hole U1376A. Major operation milestones are labeled. Dashed line $=$ planned penetration, solid red line $=$ actual penetration. Rot. $=$ rotation, ROP $=$ rate of penetration. $\mathrm{RCB}=$ rotary core barrel, triple combo = triple combination, $\mathrm{GBM}=$ Göttingen Borehole Magnetometer, FMS = Formation MicroScanner-sonic.

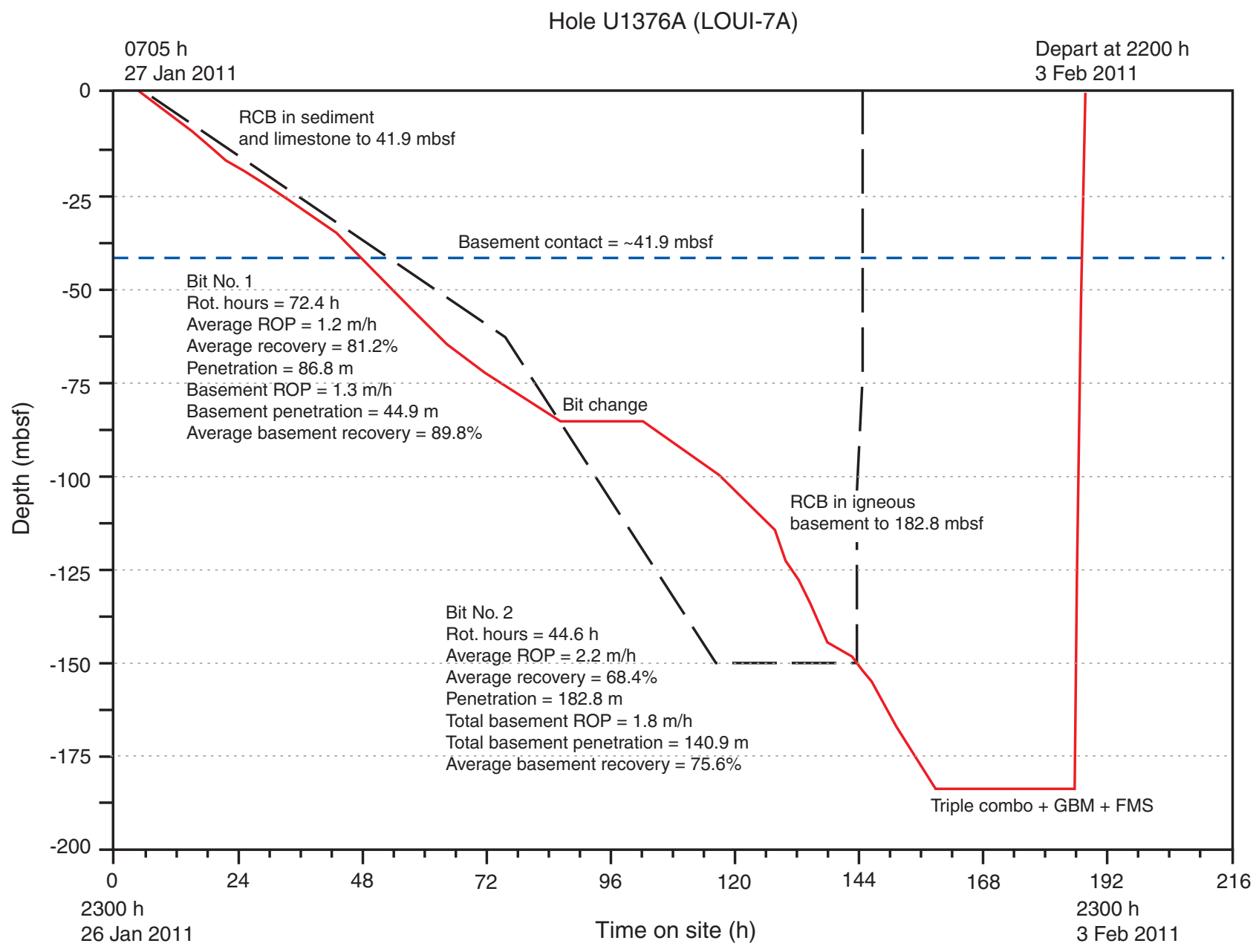


Figure F4. Stratigraphic summary of sedimentary sequences, Site U1376. See U1376A.XLS in SIZE in SEDIMENT in "Supplementary material" for estimates of grain size and roundness with depth.

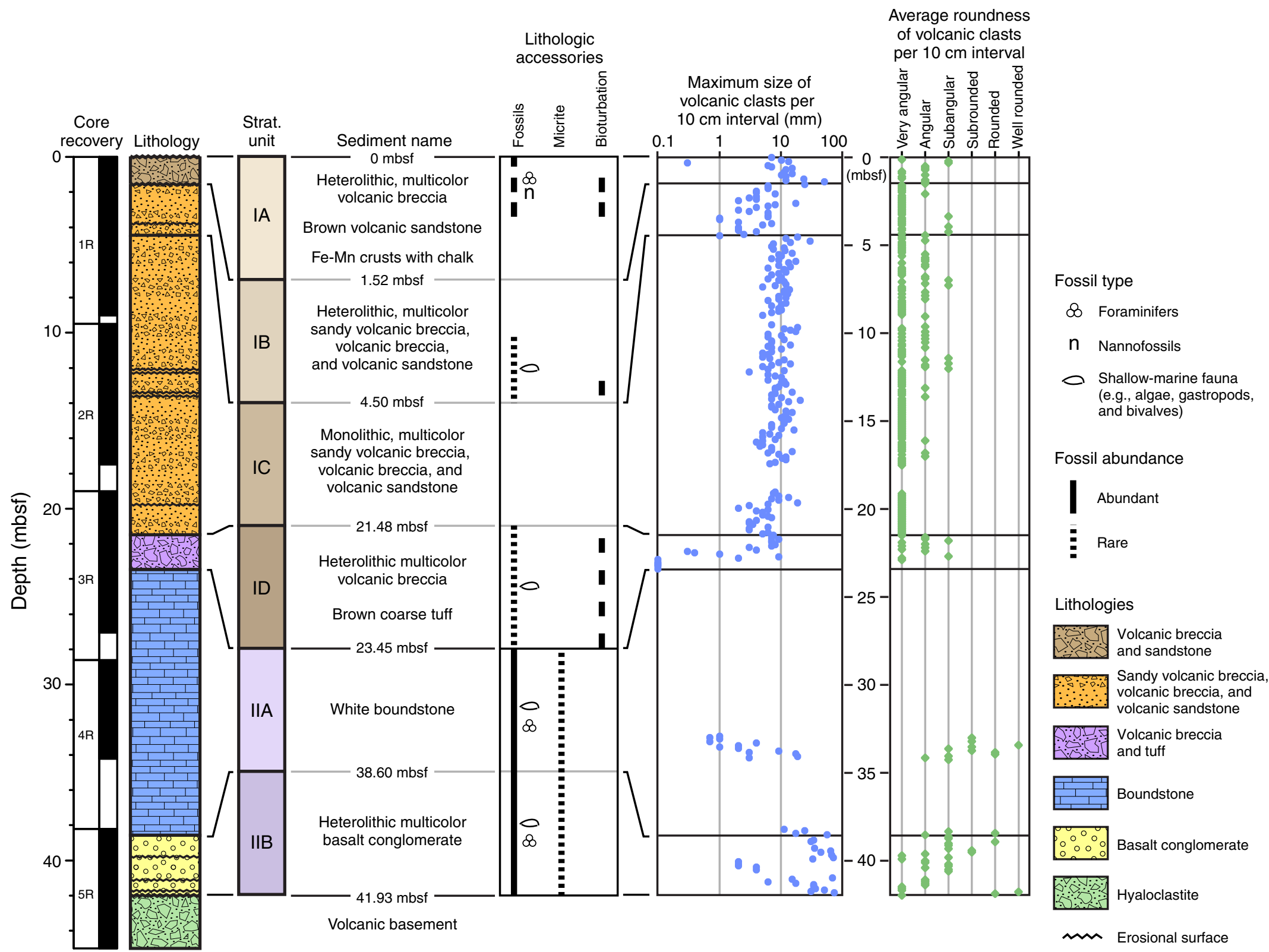


Figure F5. Close-up photographs of representative lithologies, Hole U1376A. A. Heterolithic layered multicolor basalt breccia (top and bottom) and heterolithic bioturbated volcanic sandstone (middle) in Subunit IA (interval 330-U1376A-1R-1A, 15-55 cm). Arrows show (1) ferromanganese crusts and (2) nannofossil foraminiferal chalk within a ferromanganese crust. This subunit likely consists of several hyperconcentrated flow deposits (layered breccia) and turbidites (bioturbated sandstones) emplaced in a pelagic or hemipelagic environment. B. Heterolithic layered multicolor volcanic breccia (top) and heterolithic laminated gray volcanic sandstone (bottom) in Subunit IB (interval 330-U1376A-1R-3A, 48.5-88.5 cm), interpreted to consist of hyperconcentrated flow deposits (layered breccia) and turbidites (laminated sandstones). C. Monolithic layered multicolor volcanic sandstone in Subunit IC (interval 330-U1376A-3R-1A, 44-84 cm), interpreted to represent hyperconcentrated flow deposits. D. Monolithic bioturbated brown coarse tuff (top and bottom) and heterolithic multicolor volcanic sandstone (center) in Subunit ID (interval 330-U1376A-3R-4A, 1-41 cm). Compaction features were observed, including (1) load casts and (2) a small synsedimentary fault. Subunit ID likely consists of turbidites and coarse tuff deposited in a hemipelagic or pelagic environment. E. Algal boundstone with branching growth form of alga in Subunit IIA (interval 330-U1376A-3R-5A, 10-29 cm), interpreted as an algal reef. F. Algal boundstone with encrusting growth form of alga and a few basalt grains in Subunit IIA (interval 330-U1376A4R-3A, 100-119 cm). G. Basalt conglomerate with small shallow-marine bioclasts in Subunit IIB (interval 330U1376A-5R-2A, 27-46 cm). Also shown are (1) a basalt sandstone clast, (2) an erosional surface, and (3) large algal fragments. This subunit is interpreted as shallow-marine sediment deposited on top of volcanic basement. H. Basalt conglomerate with shallow-marine bioclasts in Subunit IIB (interval 330-U1376A-5R-3A, 106-125 $\mathrm{cm})$. Also shown are (1) an erosional contact in basalt conglomerate and (2) an erosional contact with underlying volcanic basement (Unit III). (Figure shown on next page.) 

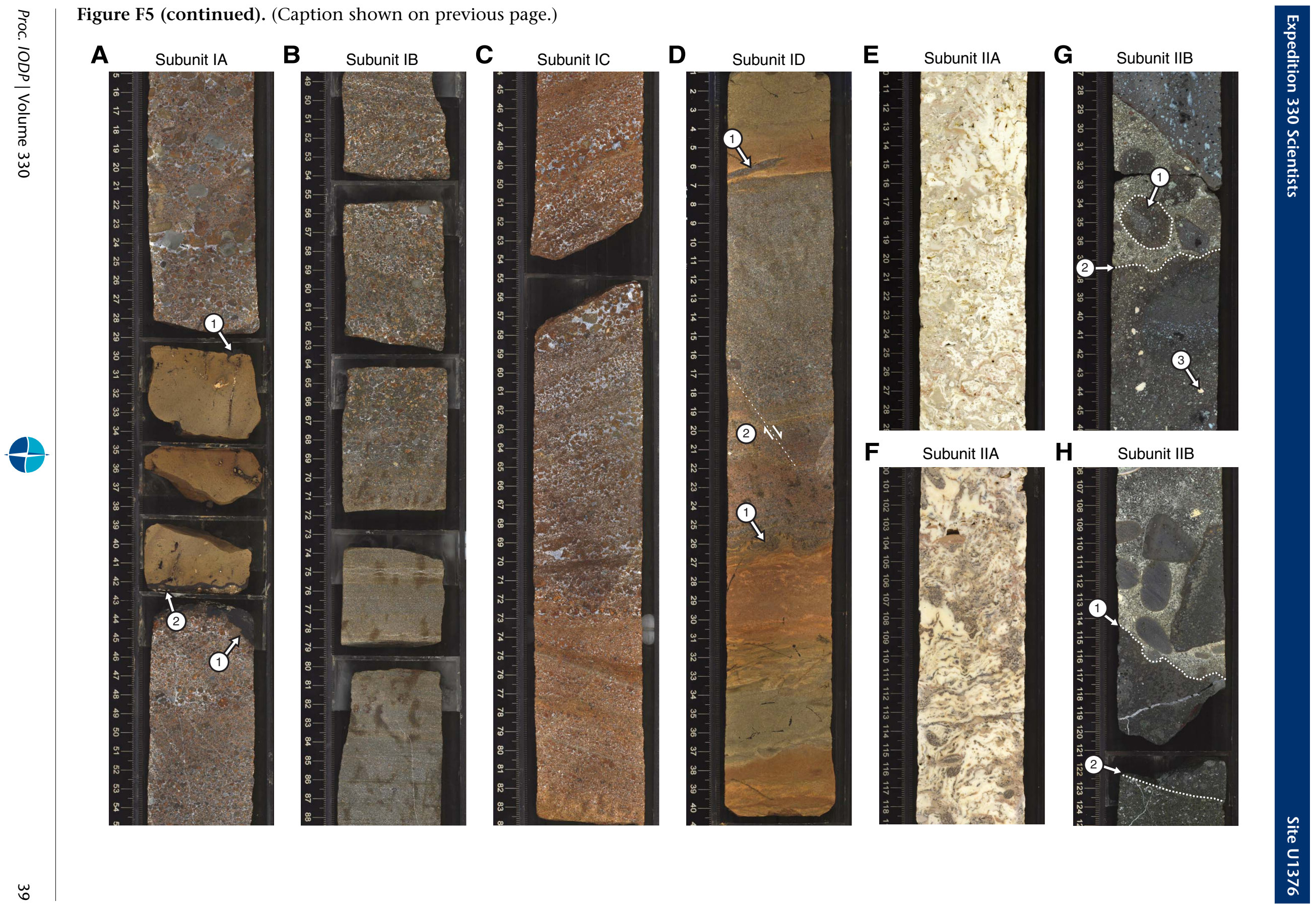
Figure F6. Close-up photograph and thin section plane-polarized photomicrographs displaying cement types and dissolution features in Unit II. Orange arrows point toward top. A. Geopetal structure in an algal framework in Subunit IIA (interval 330-U1376A-4R-3W, 102.5-107.5 cm), including (1) fossil-barren yellowish micrite filling a probable dissolution void and (2) valves of a boring bivalve inside a borehole. B. Dissolution void filled with fossil-barren micrite in algal rudstone in Subunit IIA (Sample 330-U1376A-3R-4, 129-133 cm; Thin Section 239). Arrows indicate dissolution surface of original rudstone. C. Basalt conglomerate with (1) dogtooth cement and (2) a geopetal structure defined by vadose silt and sparry calcite cement in Subunit IIB (Sample 330-U1376A-5R-1, 65-67 cm; Thin Section 244). Cement and structure indicate a vadose environment of cementation. D. Basalt conglomerate with two generations of calcite cement (fibrous and granular) in Subunit IIB (Sample 330-U1376A-5R-2, 80-83 cm; Thin Section 245). Arrows indicate occurrence of fibrous fringing cement.

A

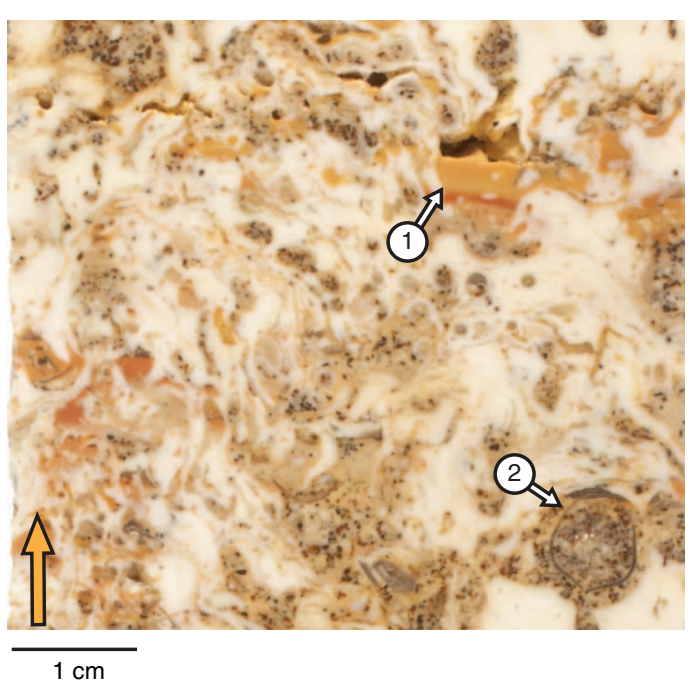

C

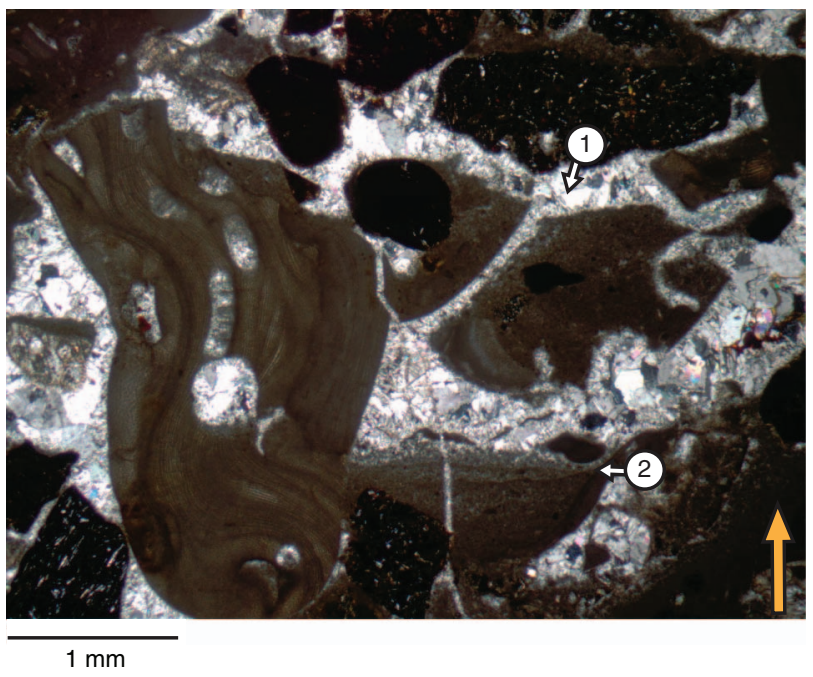

B

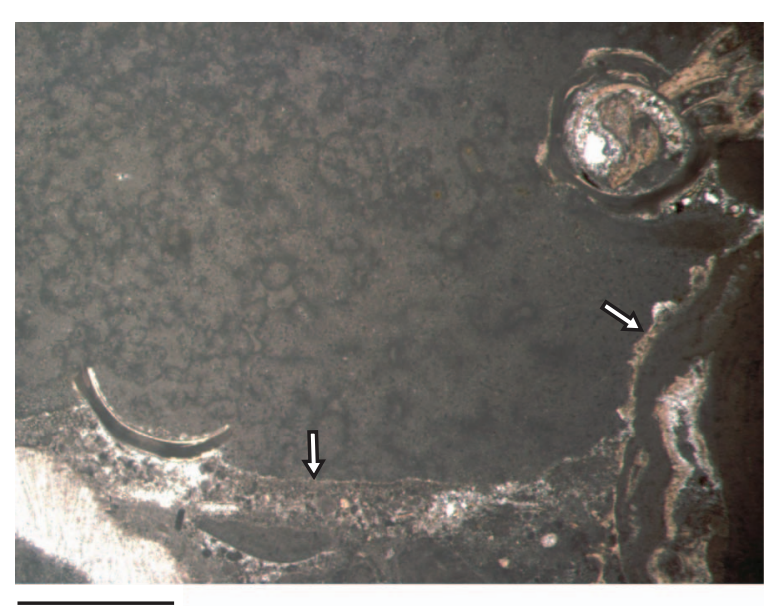

$1 \mathrm{~mm}$
D

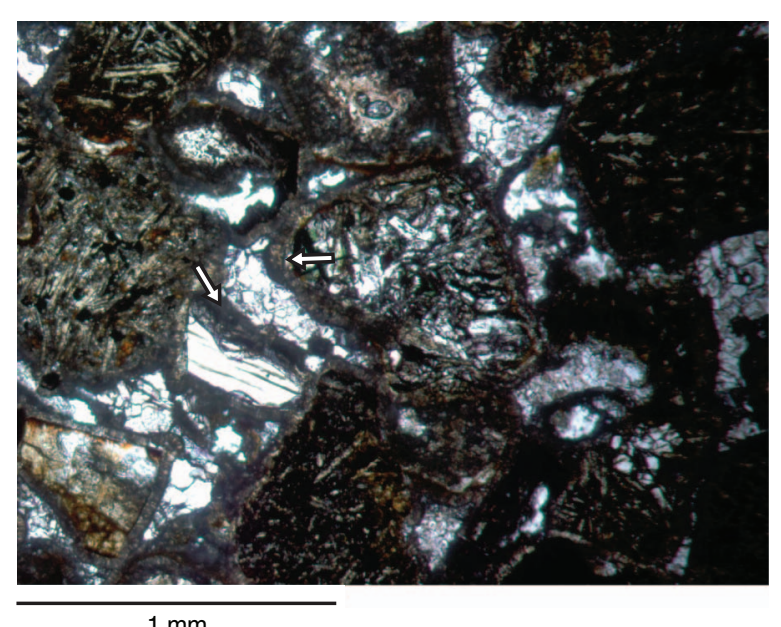

$1 \mathrm{~mm}$ 
Figure F7. Calcareous nannofossil and planktonic foraminiferal biozonation, Hole U1376A. Gray shaded areas $=$ intervals barren of age-diagnostic calcareous microfossils. ${ }^{*}=$ based on macrofossil evidence. For legend of lithology patterns, see Figure F4.

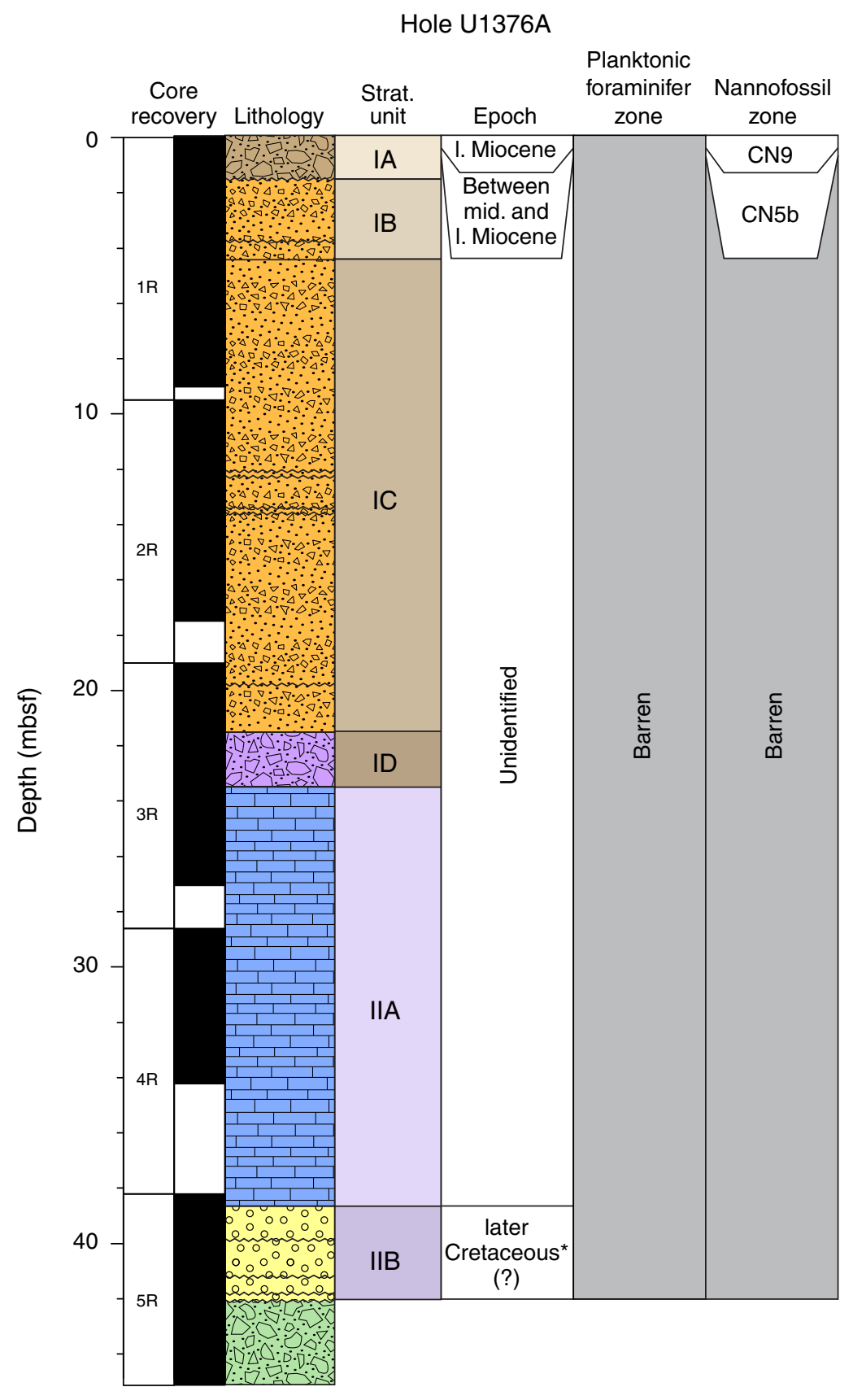


Figure F8. Close-up photographs of possible later Cretaceous rudist fossil (Sample 330-U1376A-5R-3, 101$106 \mathrm{~cm}$ ). A. Cut surface of the working (left) and archive (right) halves. B. Top piece of assembled working (left) and archive (right) halves.
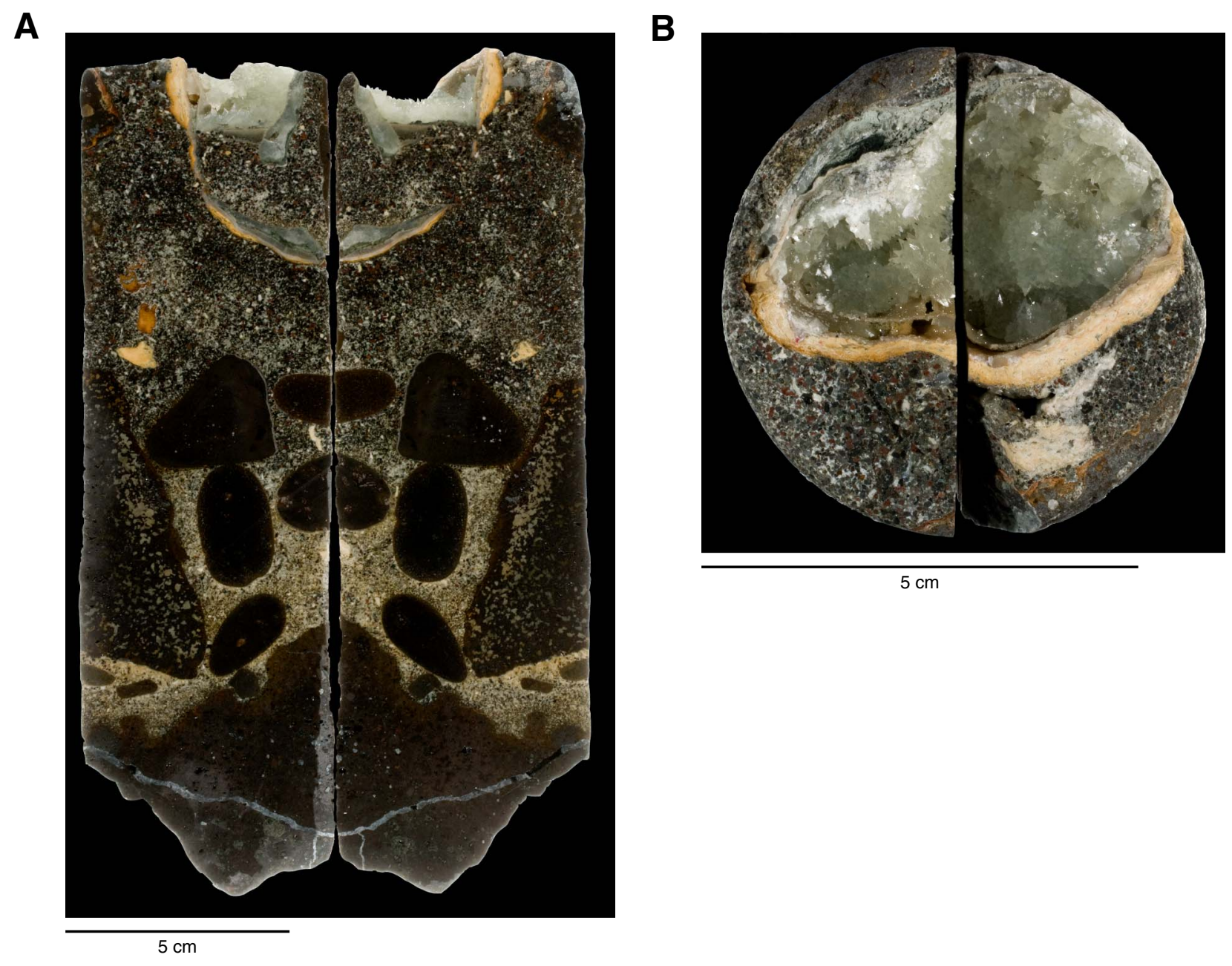
Figure F9. Close-up photographs of possible later Cretaceous rudist fossil (Sample 330-U1376A-5R-3, 101$106 \mathrm{~cm}$ ). A. Drilled surface of archive half. Rectangle indicates area of B. B. Extreme close-up photograph of shell material.

A

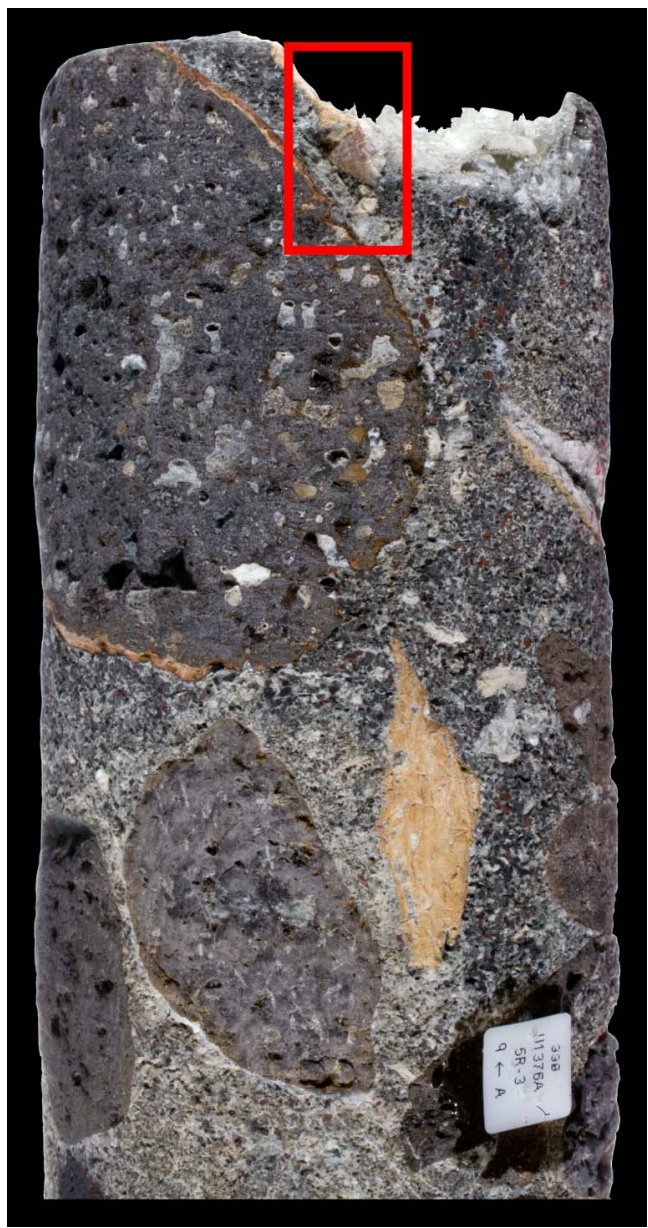

$5 \mathrm{~cm}$
B

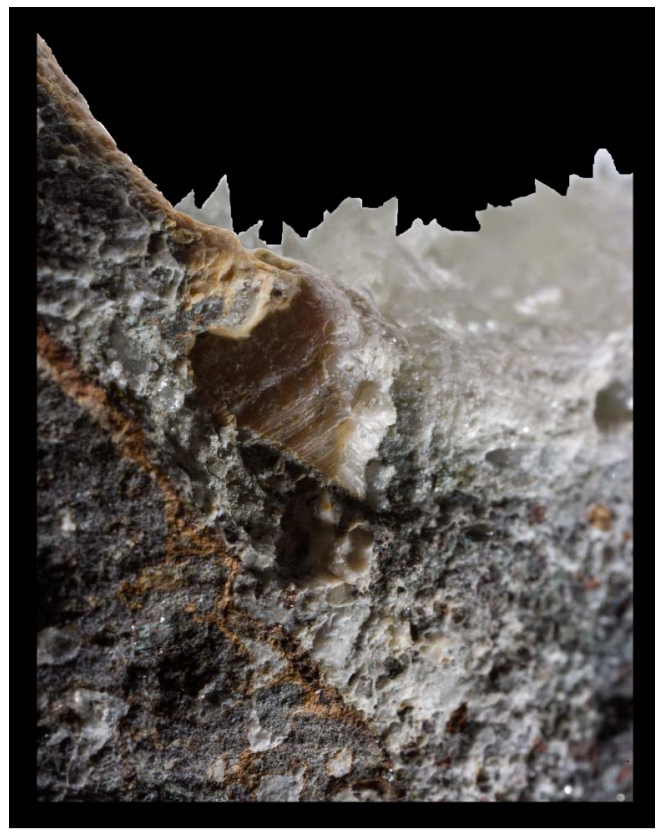

$1 \mathrm{~cm}$ 
Figure F10. Stratigraphic summary of igneous rock types and lithologic features, Hole U1376A. Individual lithologic units mentioned in text are numbered. ISCI = in situ confidence index.

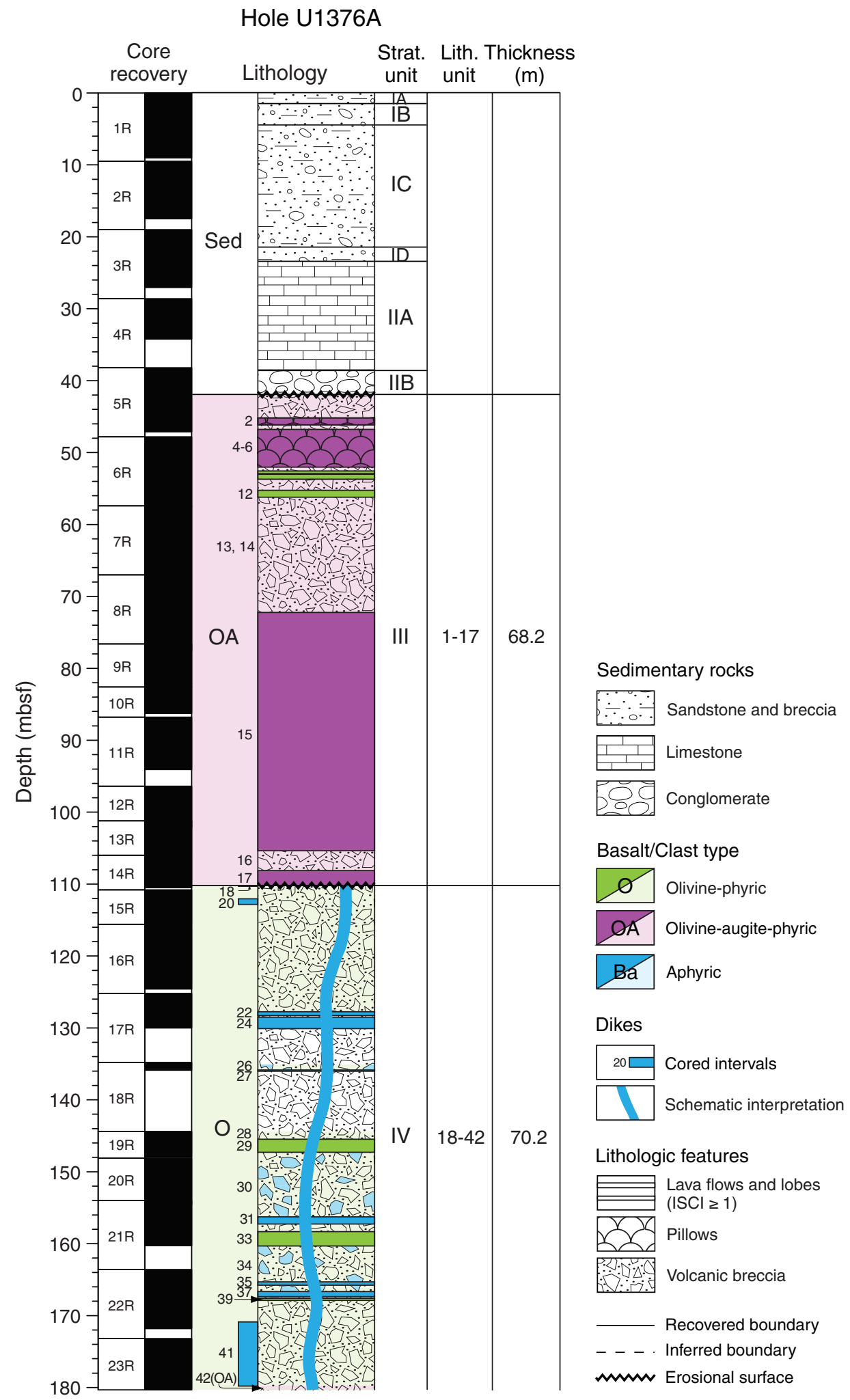


Figure F11. Scanned core photograph of volcanic breccia composed of angular basalt clasts cemented with calcite from Subunit IC (interval 330-U1376A-1R-4A, 37-49 cm). Thin section shown in Figure F12 was taken from interval 1R-4W, 39-42 cm.

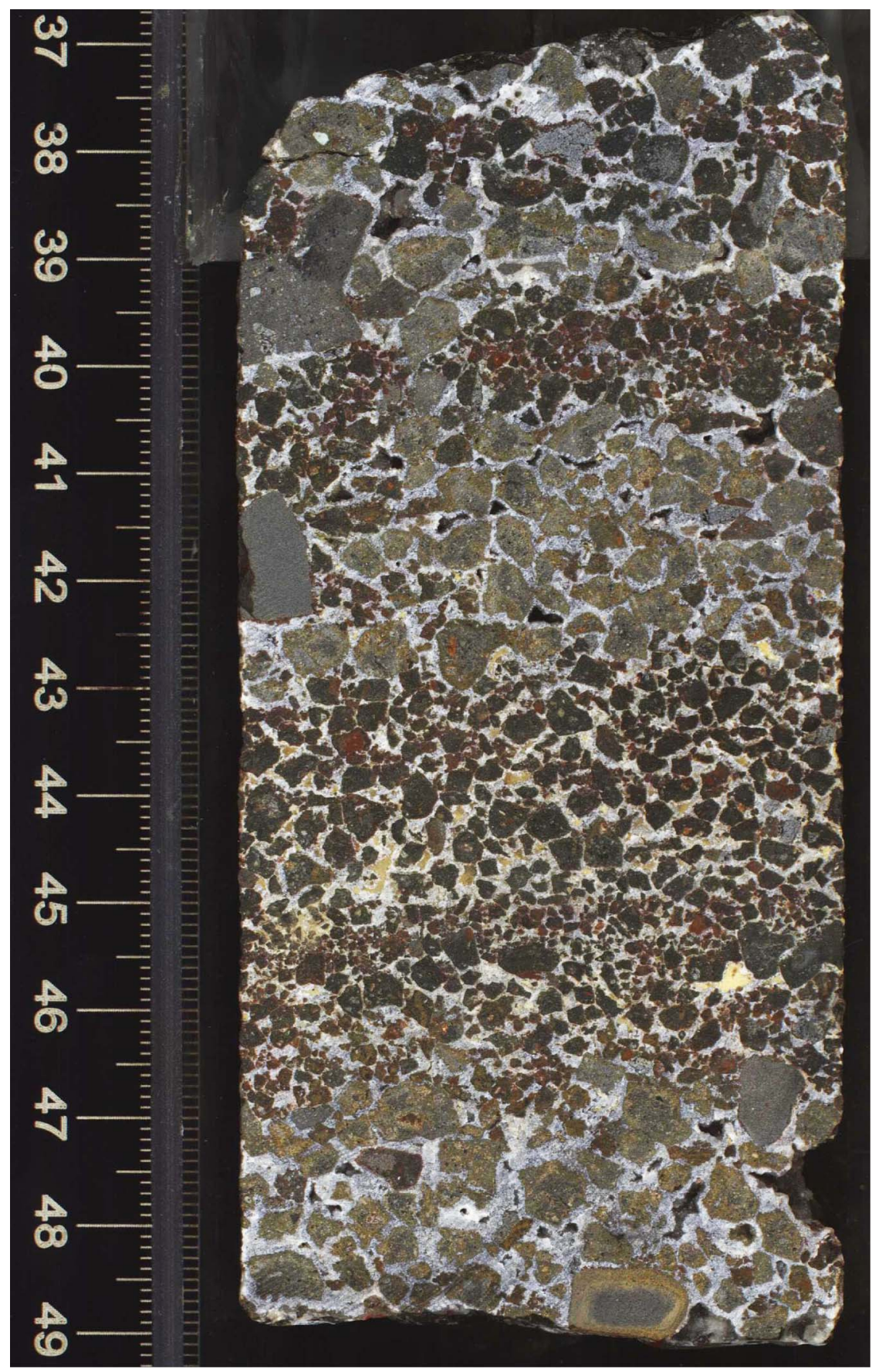


Figure F12. Thin section photomicrographs from Subunit IC (Sample 330-U1376A-1R-4W, 39-42 cm; Thin Section 234): (A, C) crossed polars, (B) plane-polarized light. Circle in A shows the location of B and C, which show an orthopyroxene xenocryst (OPX) surrounded by a reaction corona composed of tiny crystals of clinopyroxene (CPX). A scanned image of the archive half of this interval is shown in Figure F11.

A

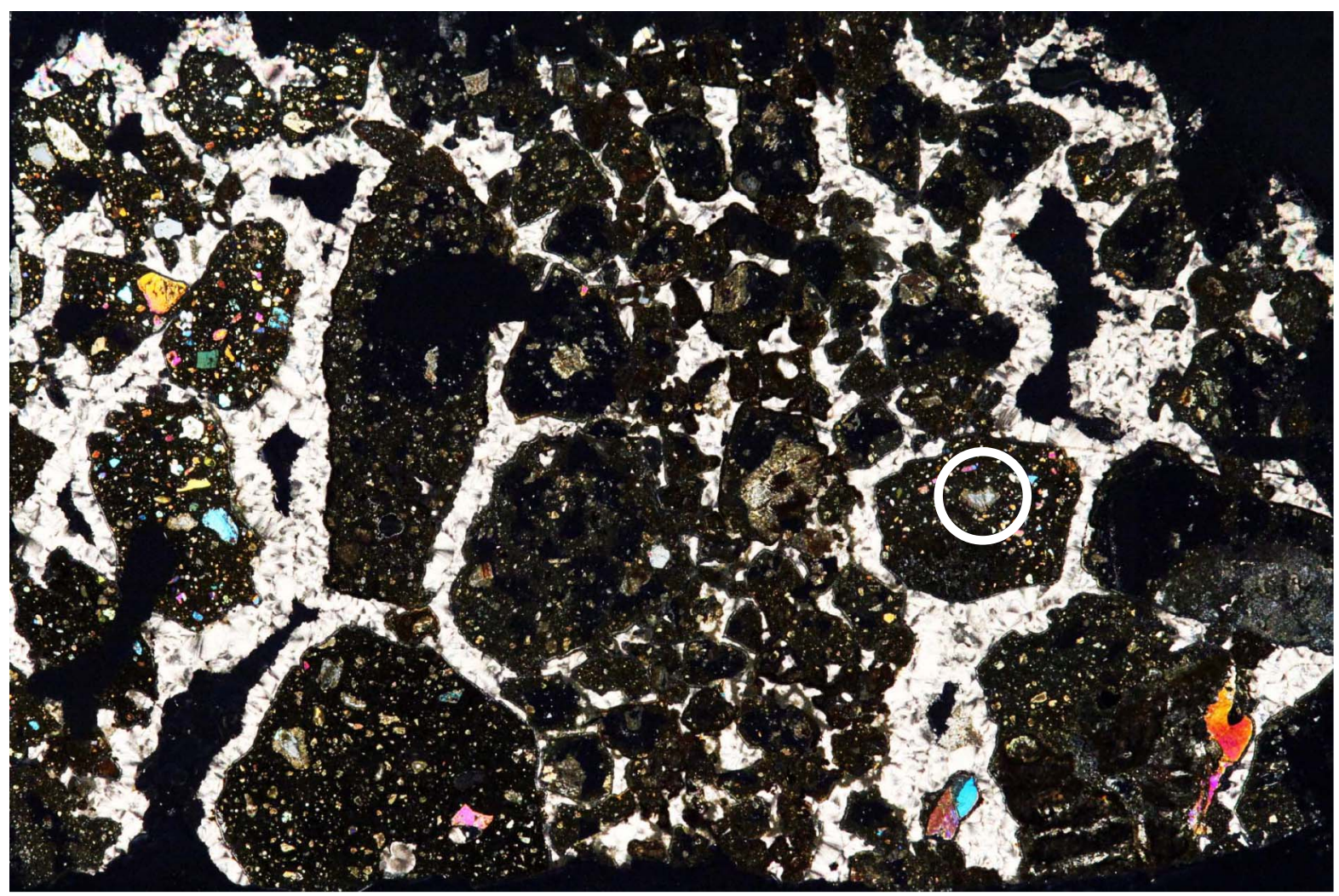

$10 \mathrm{~mm}$

B

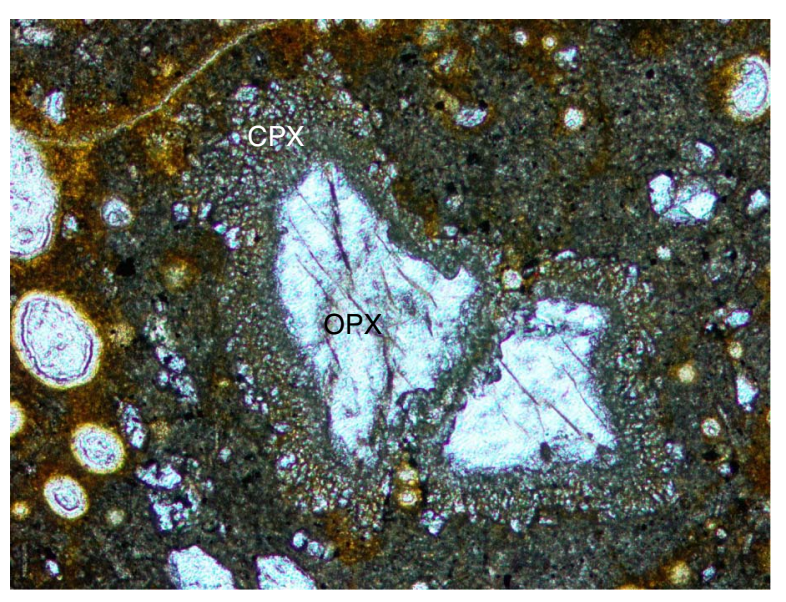

$0.5 \mathrm{~mm}$
C

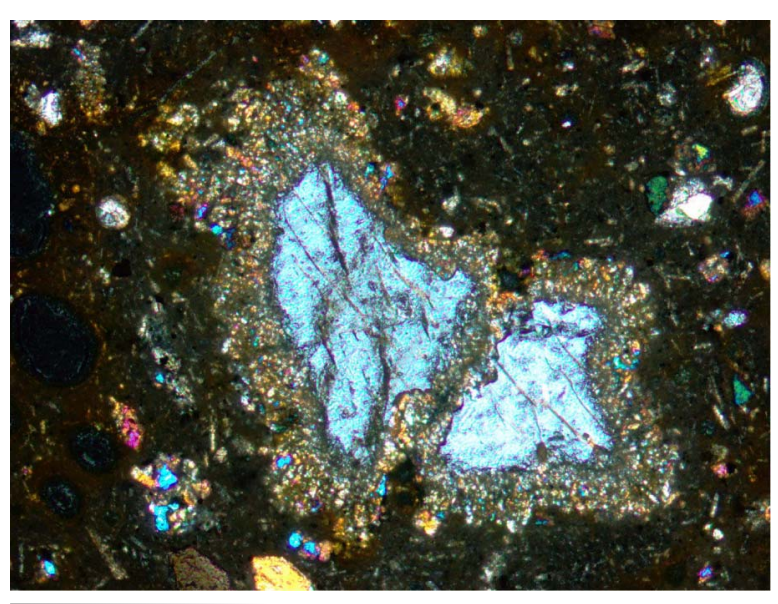

$0.5 \mathrm{~mm}$ 
Figure F13. A. Scanned core photograph of rounded bodies of olivine-augite-phyric basalt interpreted as pillows, separated by red clay containing fragments of olivine-augite-phyric basalt (interval 330-U1376A-6R2A, 79.5-103.5 cm). B. Sketch of same interval in A, highlighting areas of olivine-augite-phyric basalt (blue), chilled margins (dark blue), and interstitial clay (red).

A

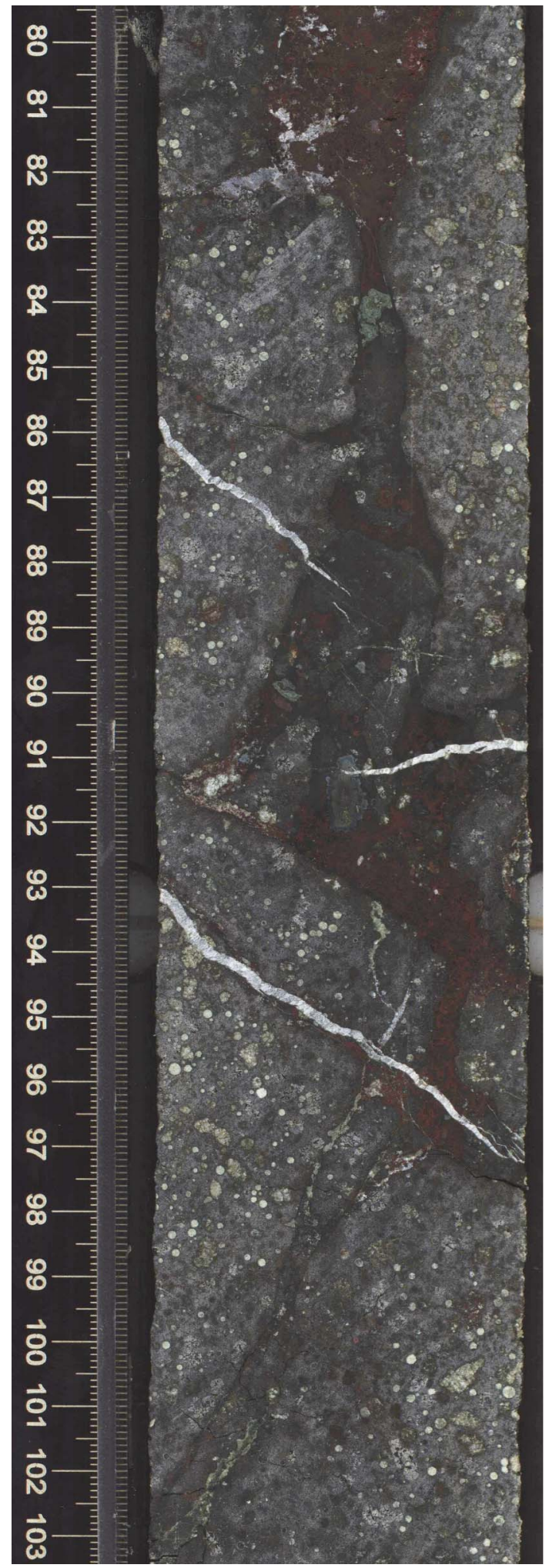

B

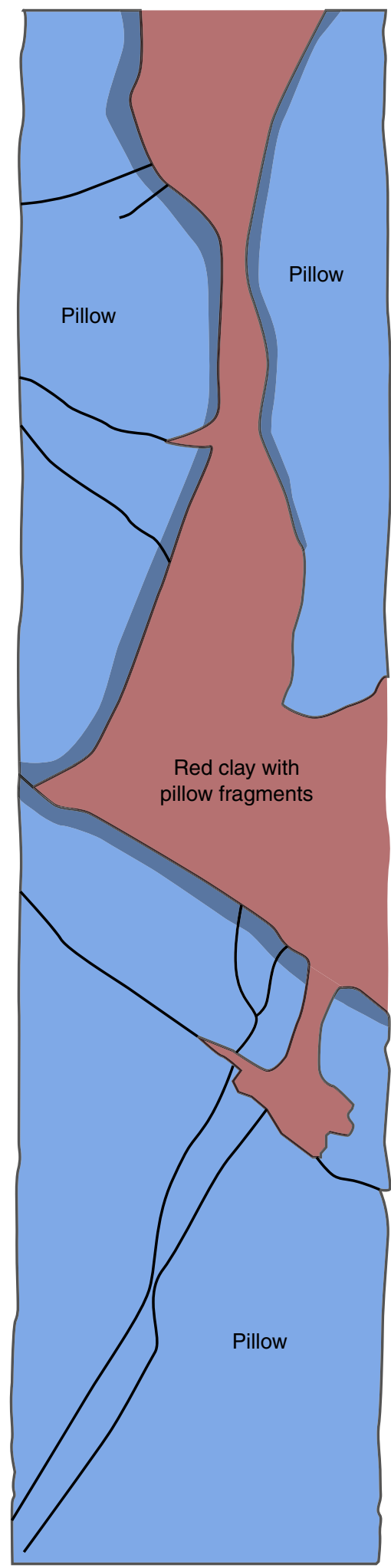


Figure F14. Thin section photomicrograph of glassy melt inclusions with shrinkage bubbles in an olivine phenocryst in lithologic Unit 12 (Sample 330-U1376A-6R-6W, 128-131 cm; Thin Section 253) (plane-polarized light).

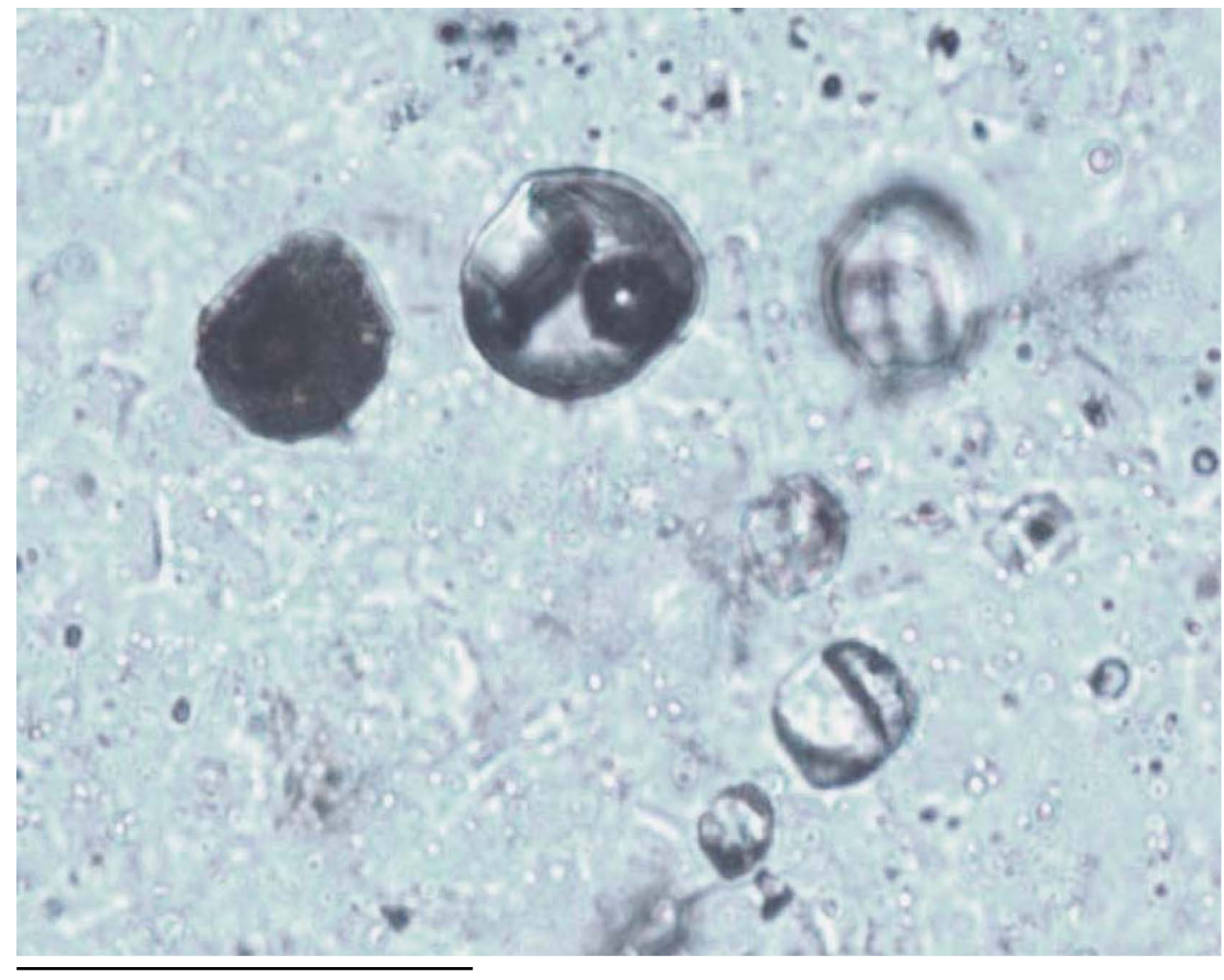

$0.05 \mathrm{~mm}$ 
Figure F15. Thin section photomicrographs of highly olivine-augite-phyric basalt from lithologic Unit 15 (Sample 330-U1376A-8R-6W, 136-140 cm; Thin Section 255): (A) plane-polarized light, (B) crossed polars.

A

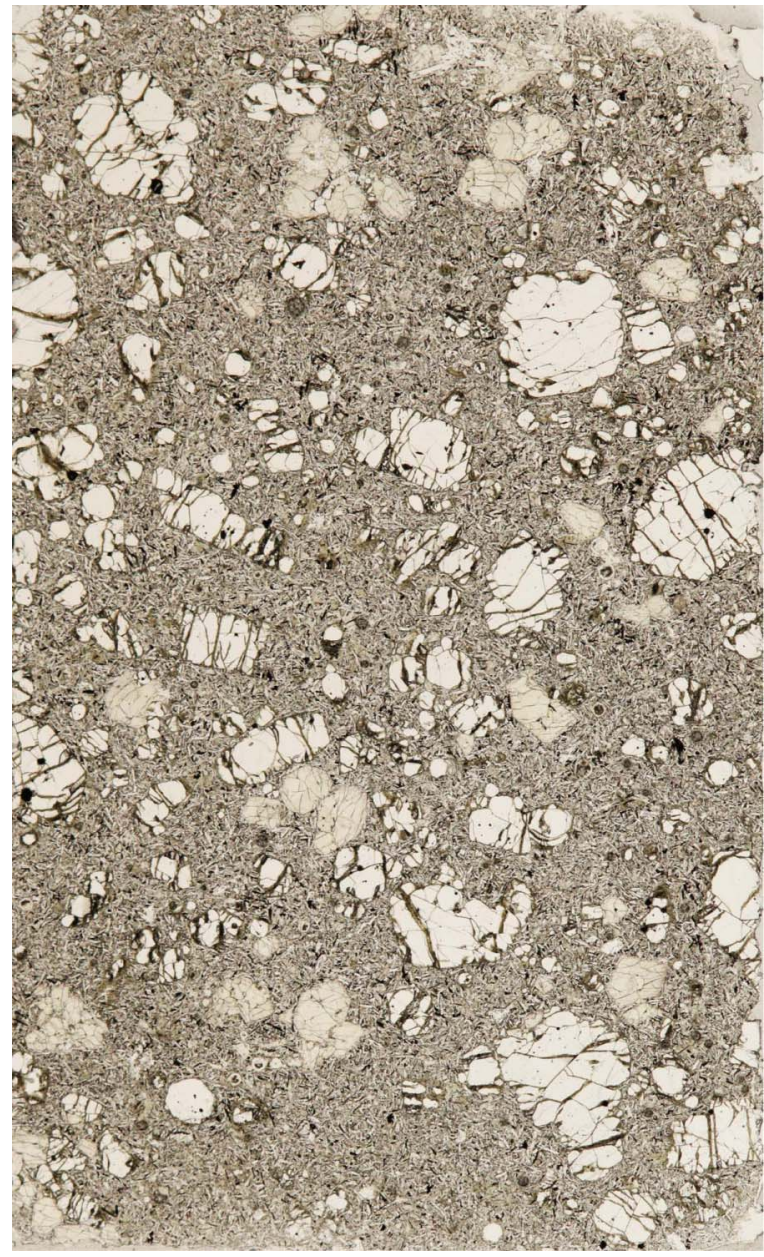

$10 \mathrm{~mm}$
B

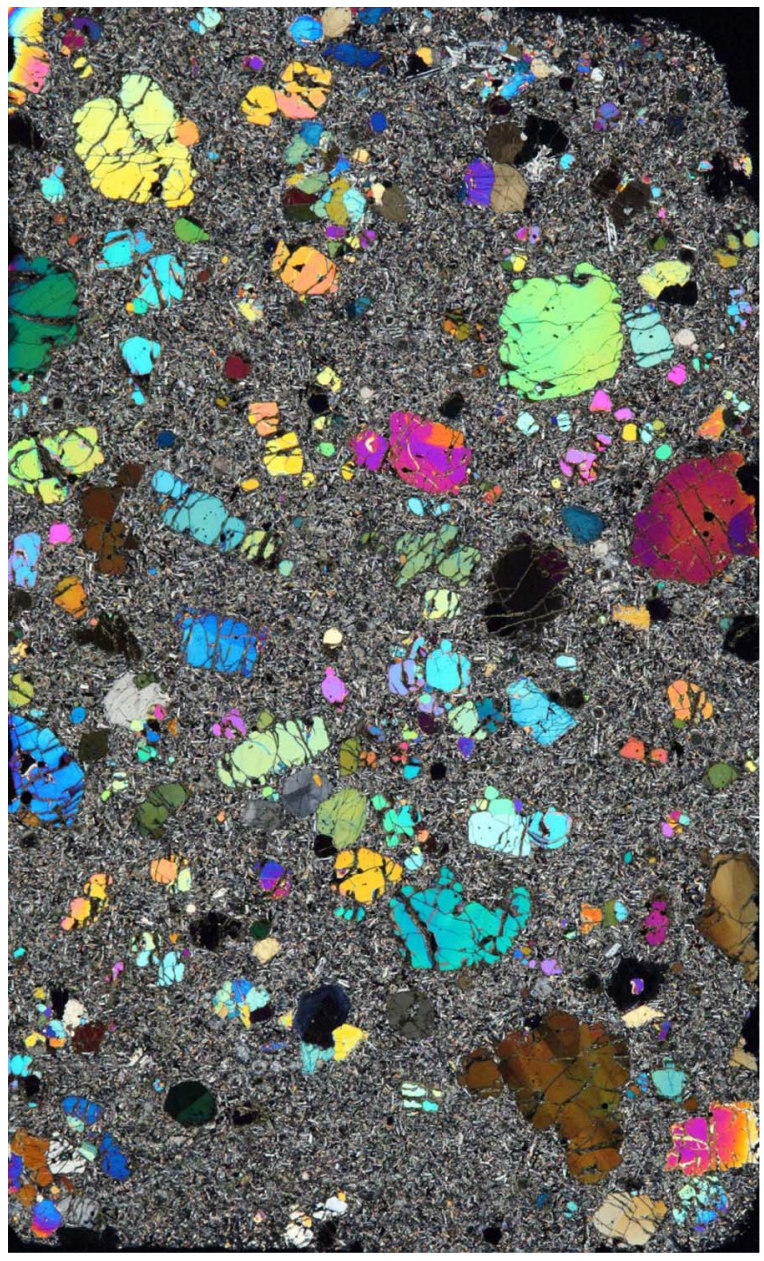

$10 \mathrm{~mm}$ 
Figure F16. Scanned core photographs and sketched interpretations of the bases of two highly olivine-augitephyric basalt lava flows in the lower part of stratigraphic Unit III. A, B. Interval 330-U1376A-13R-4A, 16$99.5 \mathrm{~cm}$ : (A) photograph and (B) sketch of breccia-filled fissure in base of $33.1 \mathrm{~m}$ thick lava flow (lithologic Unit 15), baked zone in underlying hyaloclastite breccia (lithologic Unit 16), and chilled zone at base of flow. C, D. Interval 330-U1376A-14R-4A, 30.5-82.5 cm: (C) photograph shows base of $2.1 \mathrm{~m}$ thick flow that defines the bottom of stratigraphic Unit III, (D) sketch identifies a small fragment of aphyric basalt dike (lithologic Unit 18) at contact between lava flow (lithologic Unit 17) and underlying hyaloclastite breccia (lithologic Unit 19). Dotted lines in sketch of lithologic Unit 18 show trains of small vesicles. Note that these appear to be truncated upward at base of lithologic Unit 17 and downward at lower margin of lithologic Unit 18.

A cm

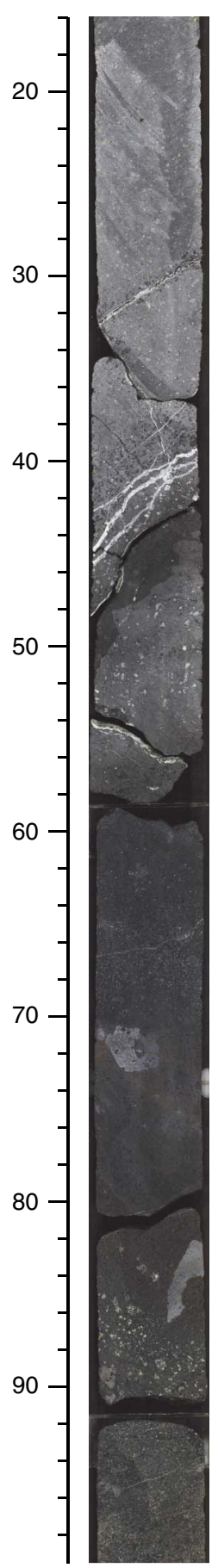

B

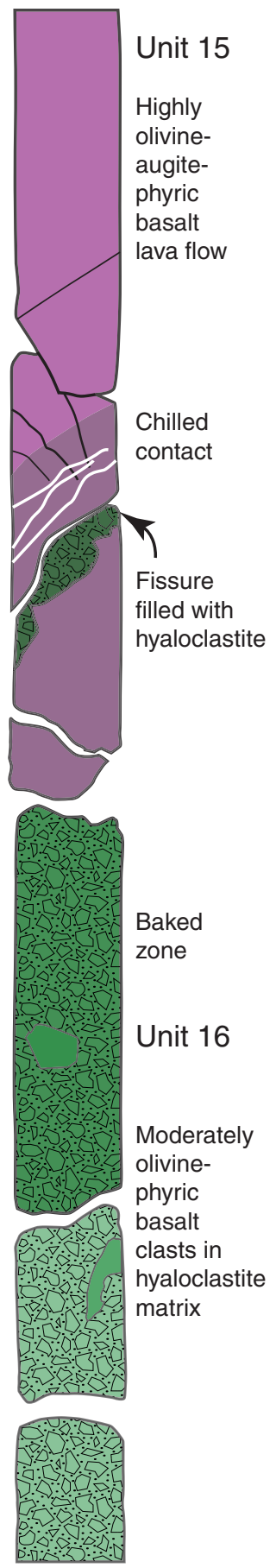

C $\mathrm{cm}$

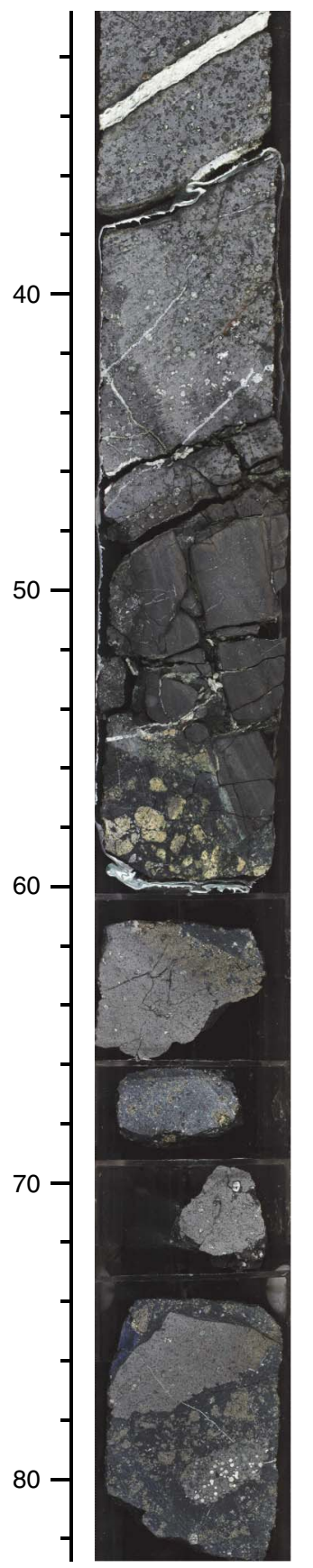

D
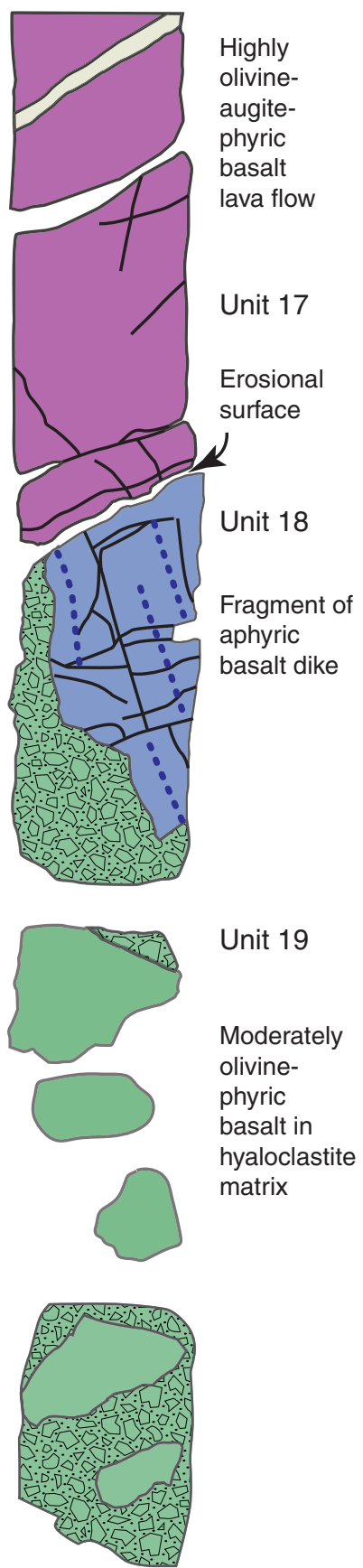
Figure F17. Scanned core photograph of hyaloclastite breccia from lithologic Unit 21 in stratigraphic Unit IV (interval 330-U1376A-16R-4A, 44.5-57 cm). Yellowish-gray color in clasts indicates presence of unaltered glass.

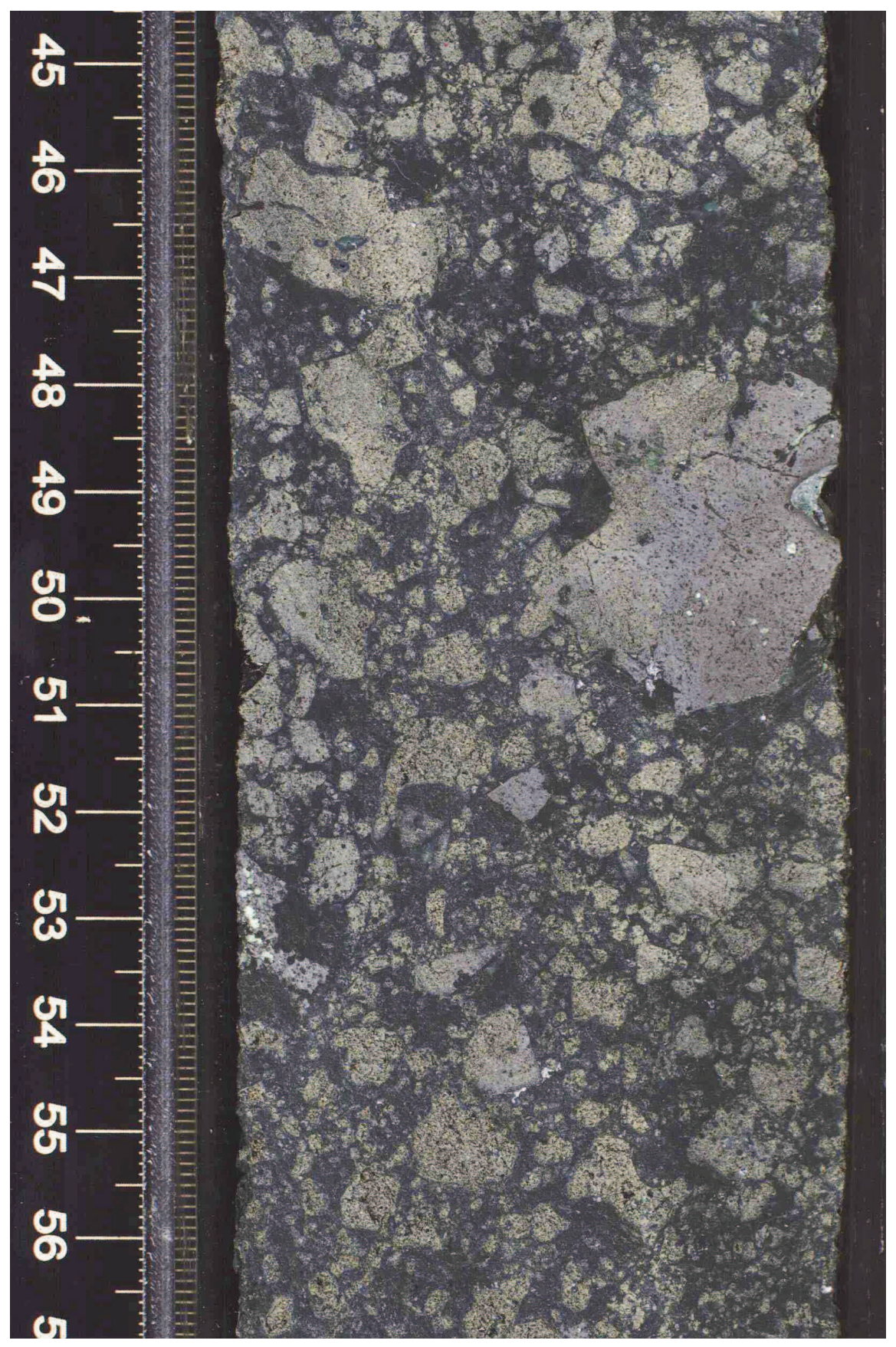


Figure F18. Thin section photomicrographs of hyaloclastite breccia from lithologic Unit 21 (Sample 330U1376A-17R-1, 140-143 cm; Thin Section 262) (plane-polarized light). A. Unaltered basaltic glass shards with curved edges. The homogeneity of the glass suggests that the fragments quenched very rapidly, and the shape of the shards suggests that they are bubble-wall fragments. Voids between glass shards are unfilled in this specimen. The darkening around shard edges is due to numerous minute tubes formed by microorganisms. B. Magnified view of A, showing euhedral olivine microphenocrysts and tiny spinel crystals in basaltic glass. The olivine crystals contain spinel and glassy melt inclusions.

A

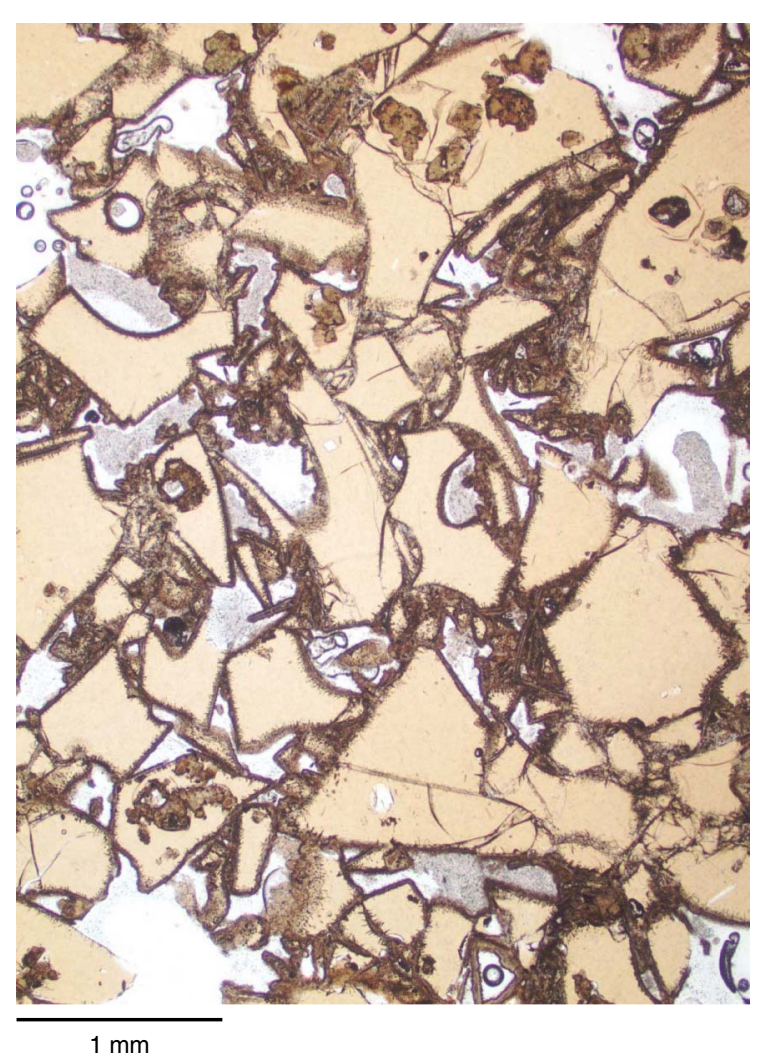

B

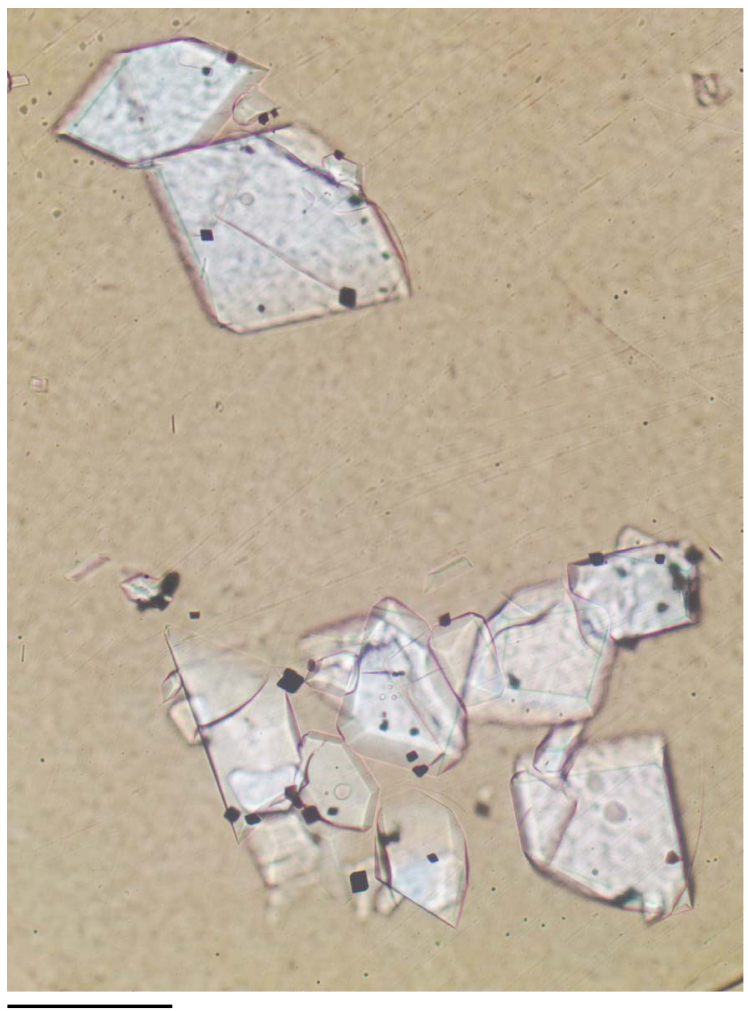

$0.1 \mathrm{~mm}$ 
Figure F19. (A) Scanned core photograph and (B) sketched interpretation of the margin of an aphyric dike (lithologic Unit 20) in interval 330-U1376A-15R-2A, 22-95.5 cm. Rows of dark blue dots in dike indicate vesicle trains.

A $\mathrm{cm}$

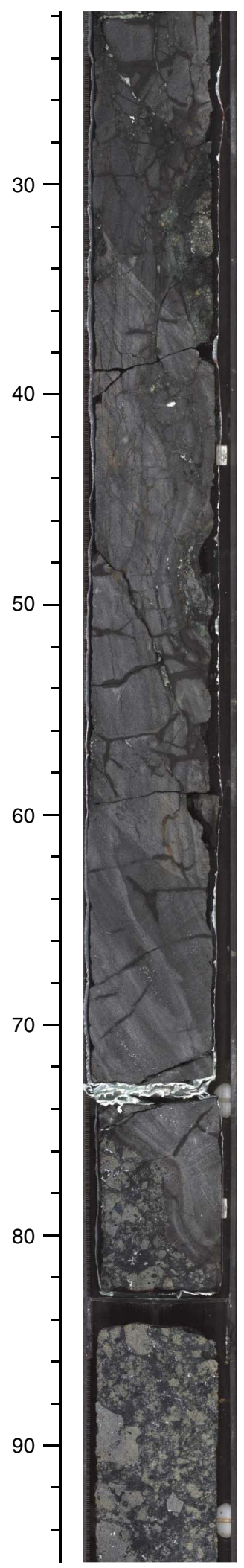

B

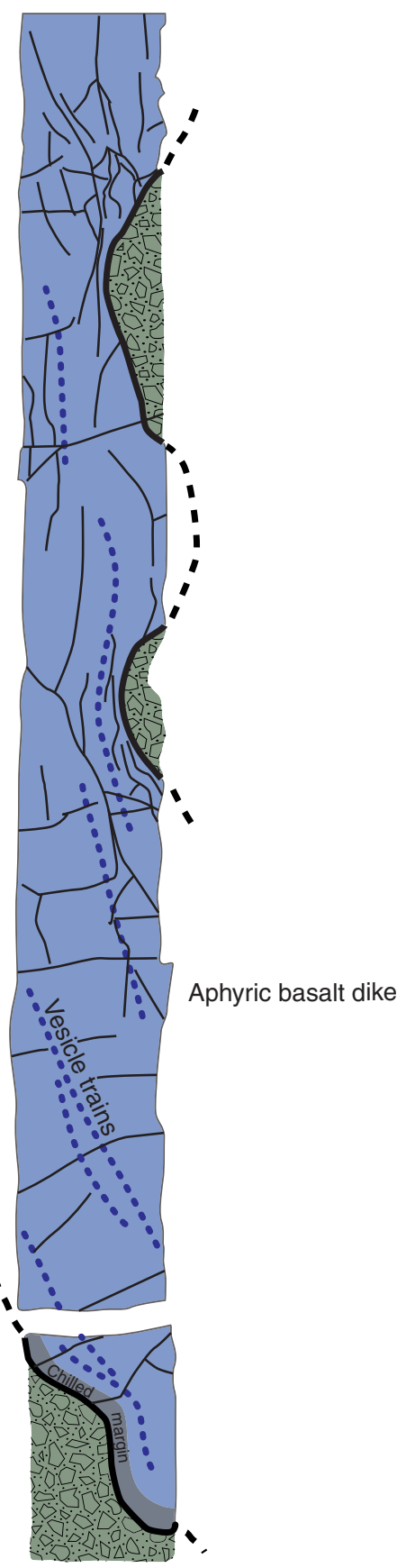

Hyaloclastite breccia 
Figure F20. Plot of downhole distribution of alteration colors and groundmass alteration (from fresh to completely altered) for each alteration interval defined by the alteration petrology group. Circles are located at center depth for each interval. Gray shading represents sedimentary units.

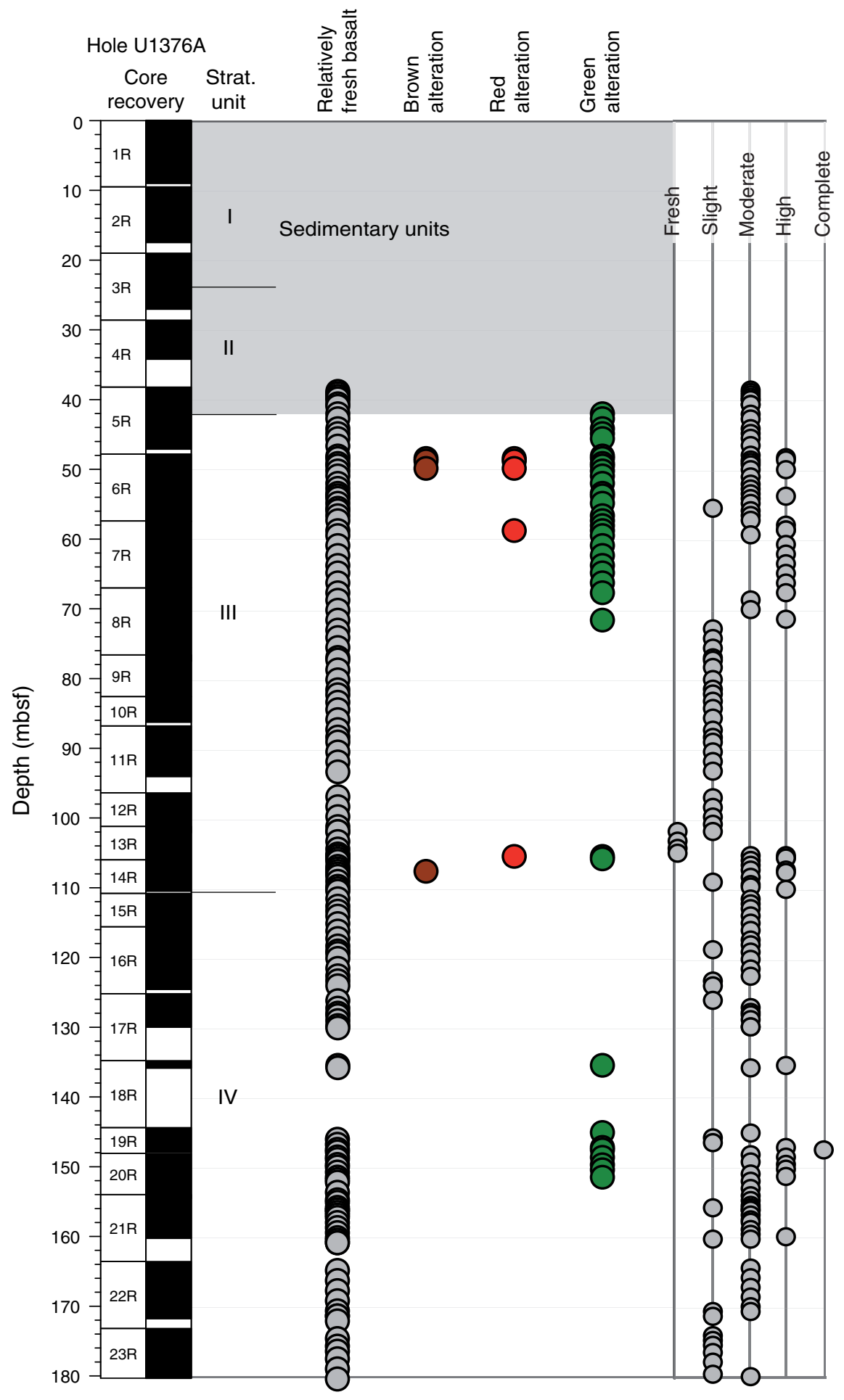


Figure F21. Plot of downhole distribution of secondary minerals after olivine for each alteration interval defined by the alteration petrology group. Symbols are located at center depth of each interval. Occurrence of fresh to moderately altered olivine is from macroscopic observations; for thin section observations, see Table T6. Gray shading represents sedimentary units.

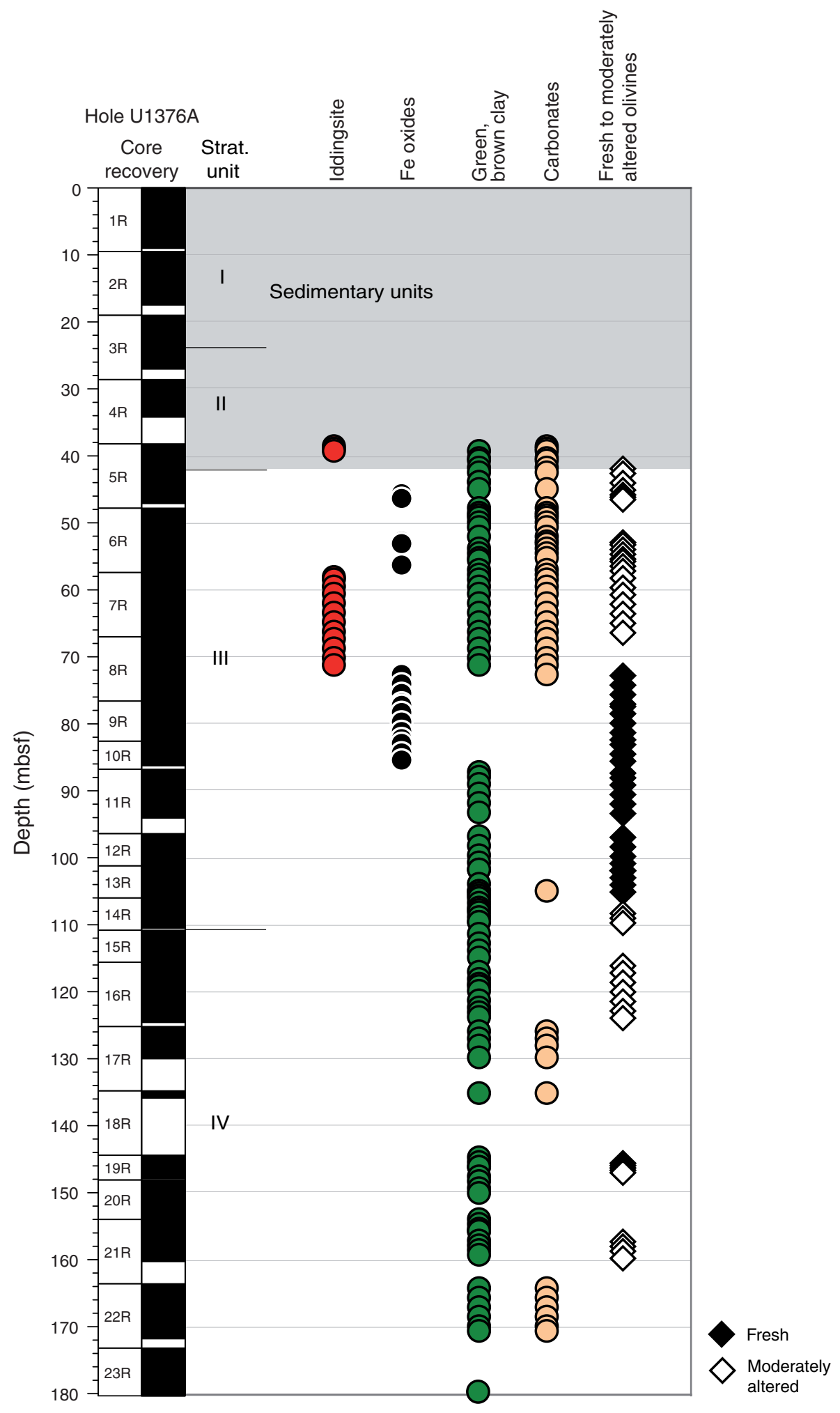


Figure F22. A, B. X-ray diffraction spectra and associated core photographs (analyzed zones are highlighted with red and black circles) (Sample 330-U1376A-6R-1, 96-98 cm). Red patches in the core are mainly composed of secondary hematite and clay minerals (bannisterite and saponite) with associated secondary aragonite and ankerite in the white, crystal-rich zones.

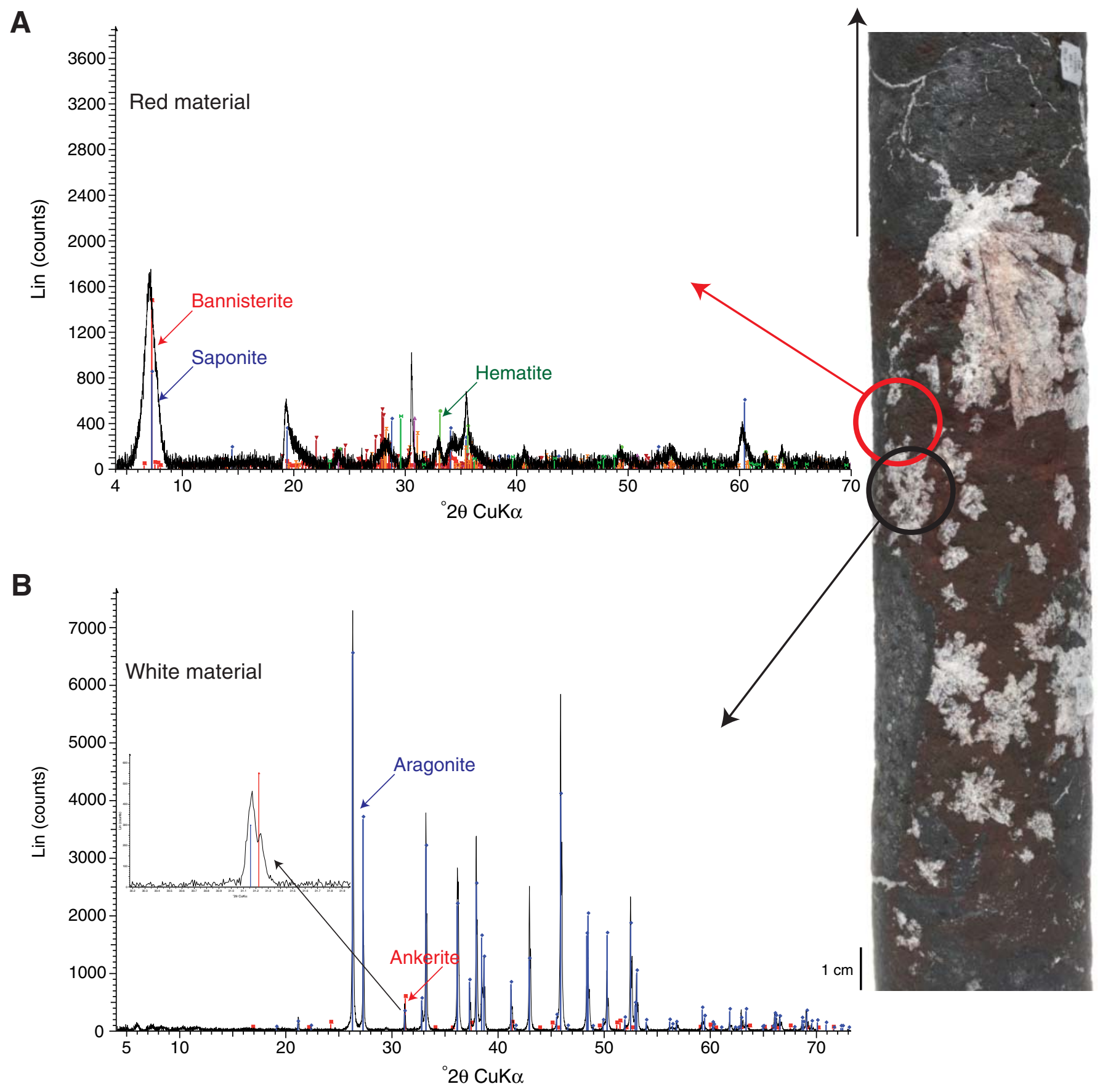


Figure F23. X-ray diffraction spectrum and associated core photograph (analyzed zones are highlighted with red circles) for vesicles showing filling of siderite having a botryoidal habit (Sample 330-U1376A-18R-1, 95-108 $\mathrm{cm})$.

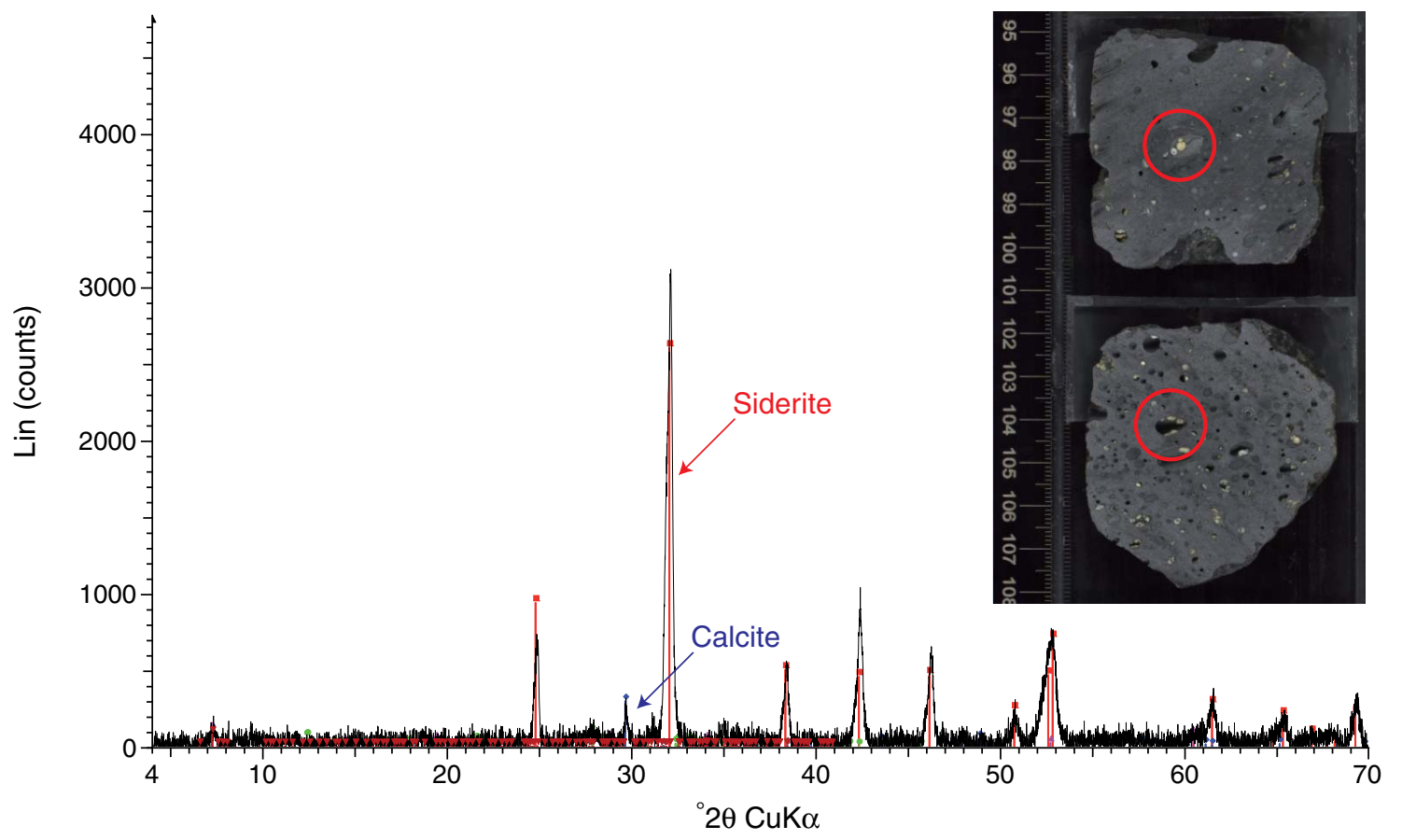


Figure F24. Plot of downhole distribution of main alteration colors representing overall color of each lithologic unit (units defined by the igneous petrology group). Circles are located at center depth for each unit. For some units, especially those in which volcanic clasts are surrounded by a volcanic matrix, the color of both clasts and matrix is reported. Gray shading represents sedimentary units.

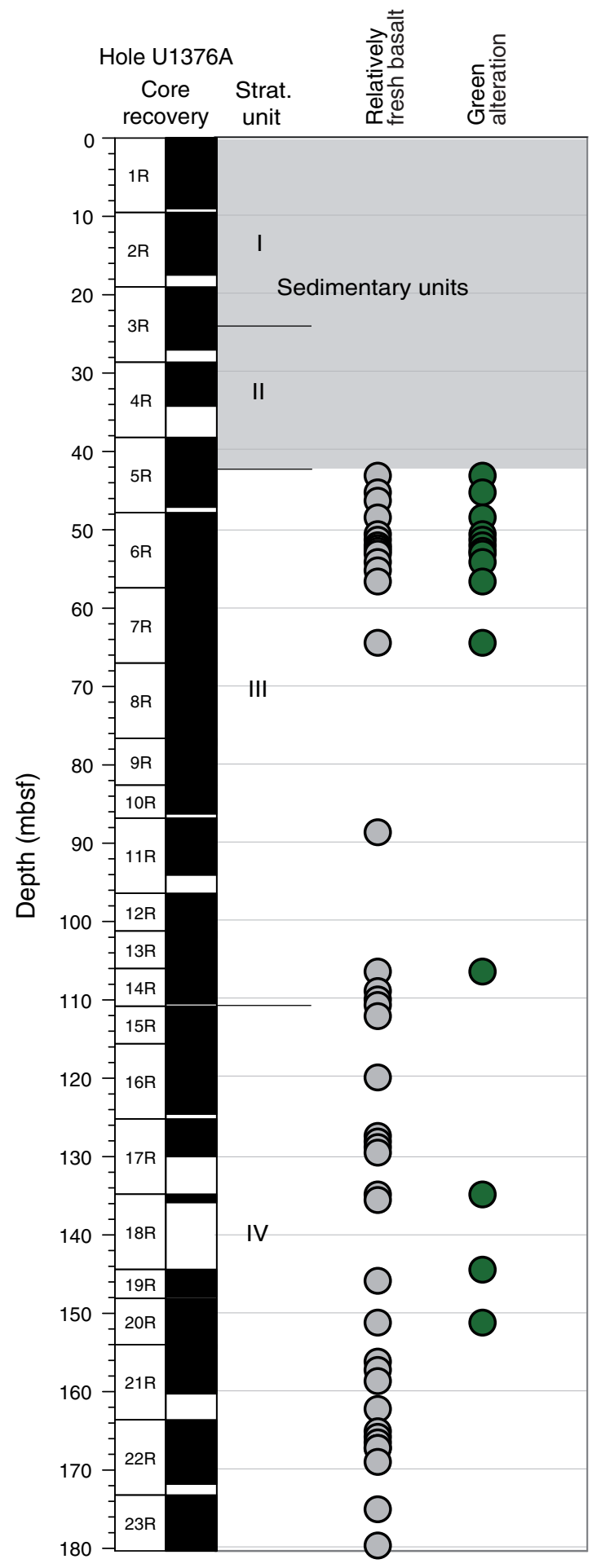


Figure F25. Thin section photomicrographs of altered olivine and groundmass. A, B. Completely altered microphenocrysts of olivine to green clay (rim) and calcite (clast in sediment; Sample 330-U1376A-5R-2, 125$127 \mathrm{~cm}$; Thin Section 246): (A) plane-polarized light, (B) crossed polars. C, D. Olivine highly altered to green and brown clay and carbonate (moderately olivine-augite-phyric basalt; Sample 330-U1376A-6R-3, 103$106 \mathrm{~cm}$; Thin Section 251): (C) plane-polarized light, (D) crossed polars. E, F. Highly altered groundmass of highly olivine-augite-phyric basalt (Sample 330-U1376A-5R-6, 97-99 cm; Thin Section 248; plane-polarized light), showing (E) secondary green clay minerals and (F) secondary hematite and palagonite.

A

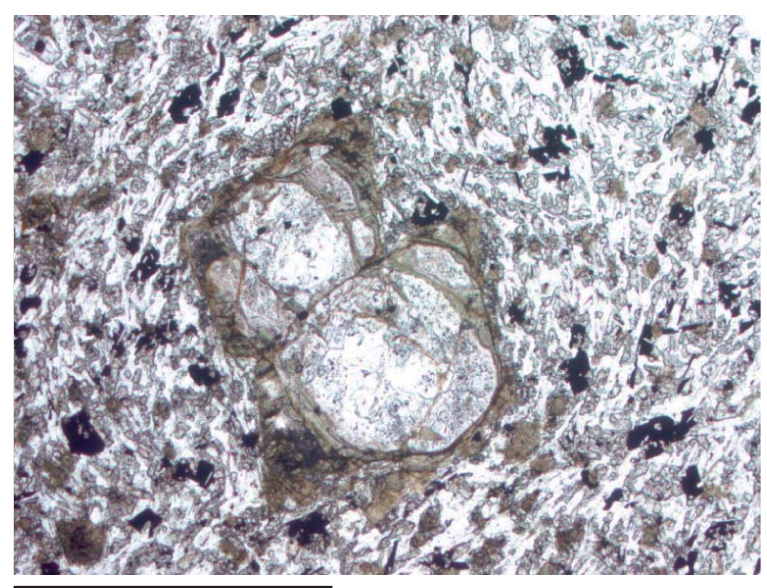

C

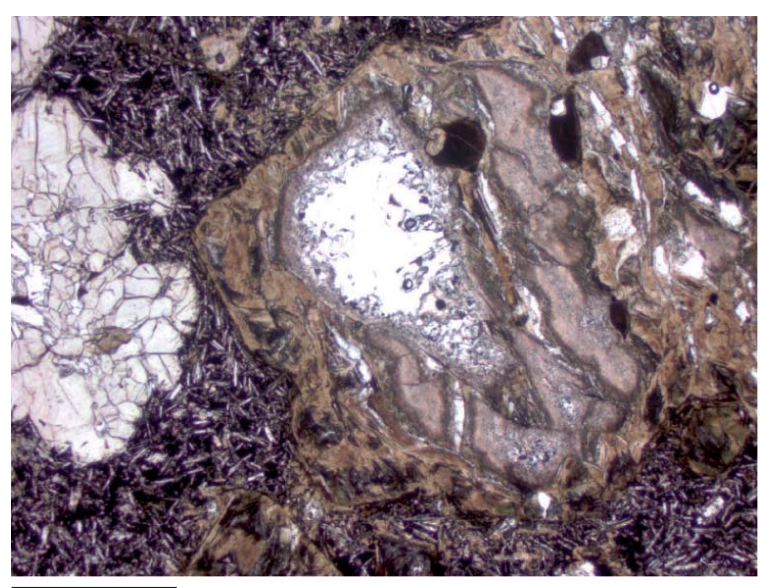

E

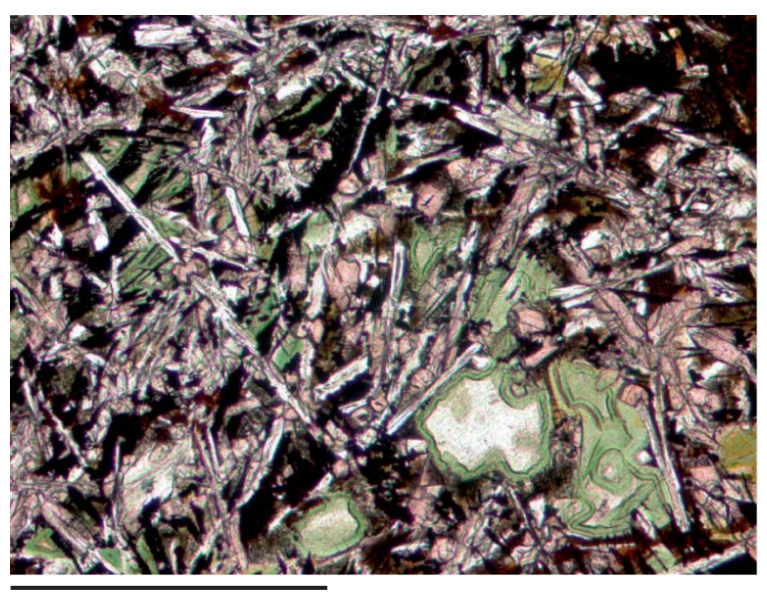

B

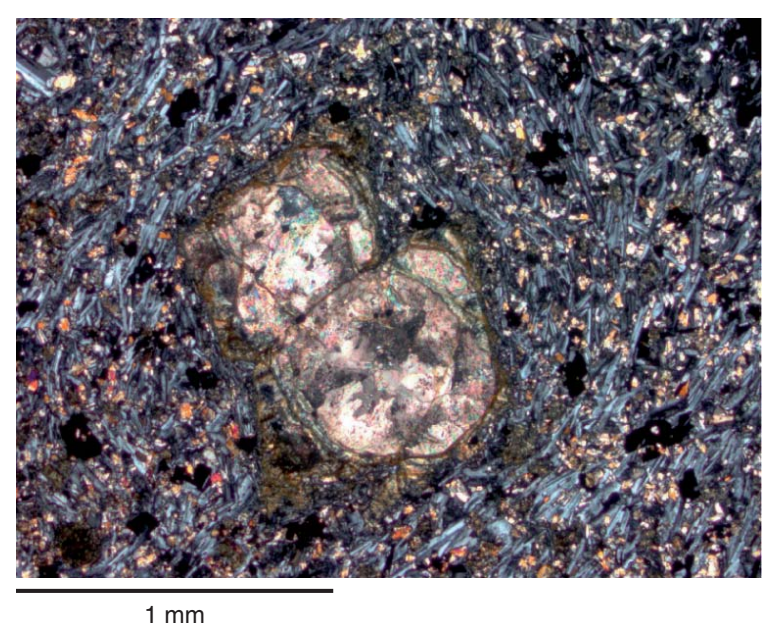

D

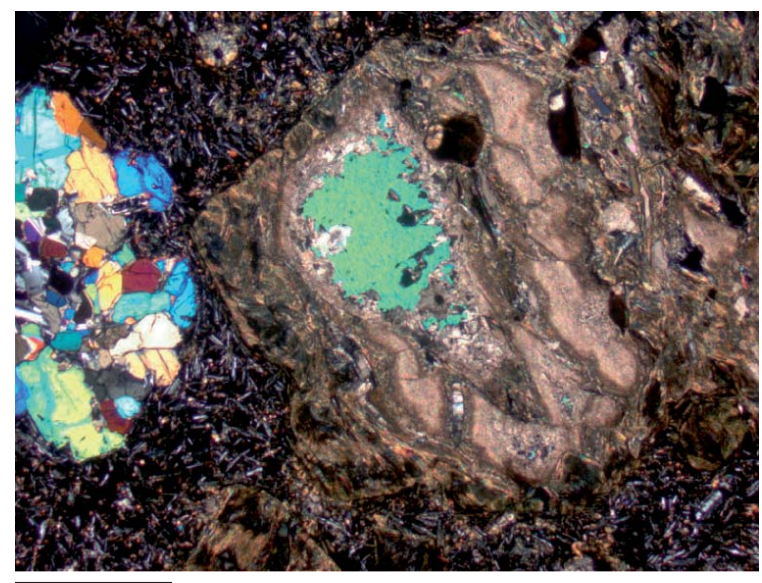

$1 \mathrm{~mm}$

$\mathbf{F}$

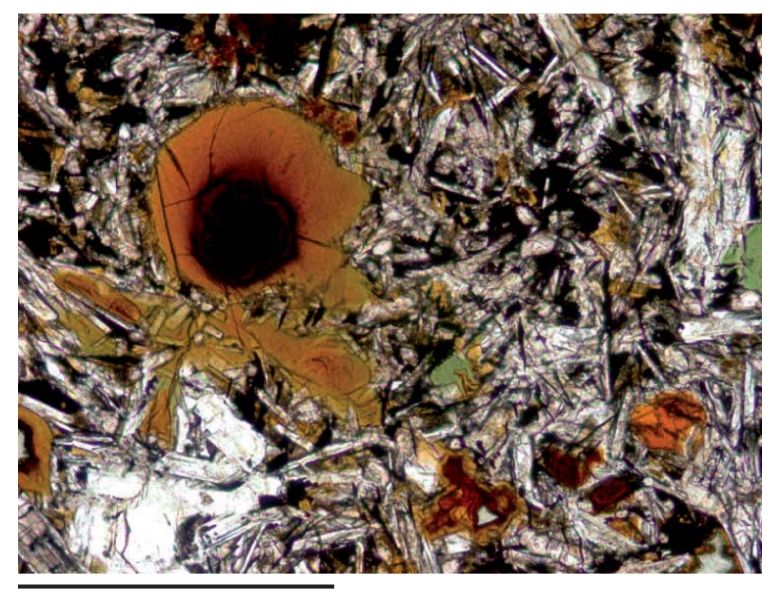

$0.5 \mathrm{~mm}$ 
Figure F26. Plot of downhole distribution of secondary minerals filling vesicles for each alteration interval defined by the alteration petrology group. Symbols are located at center depth for each interval. Gray shading represents sedimentary units.

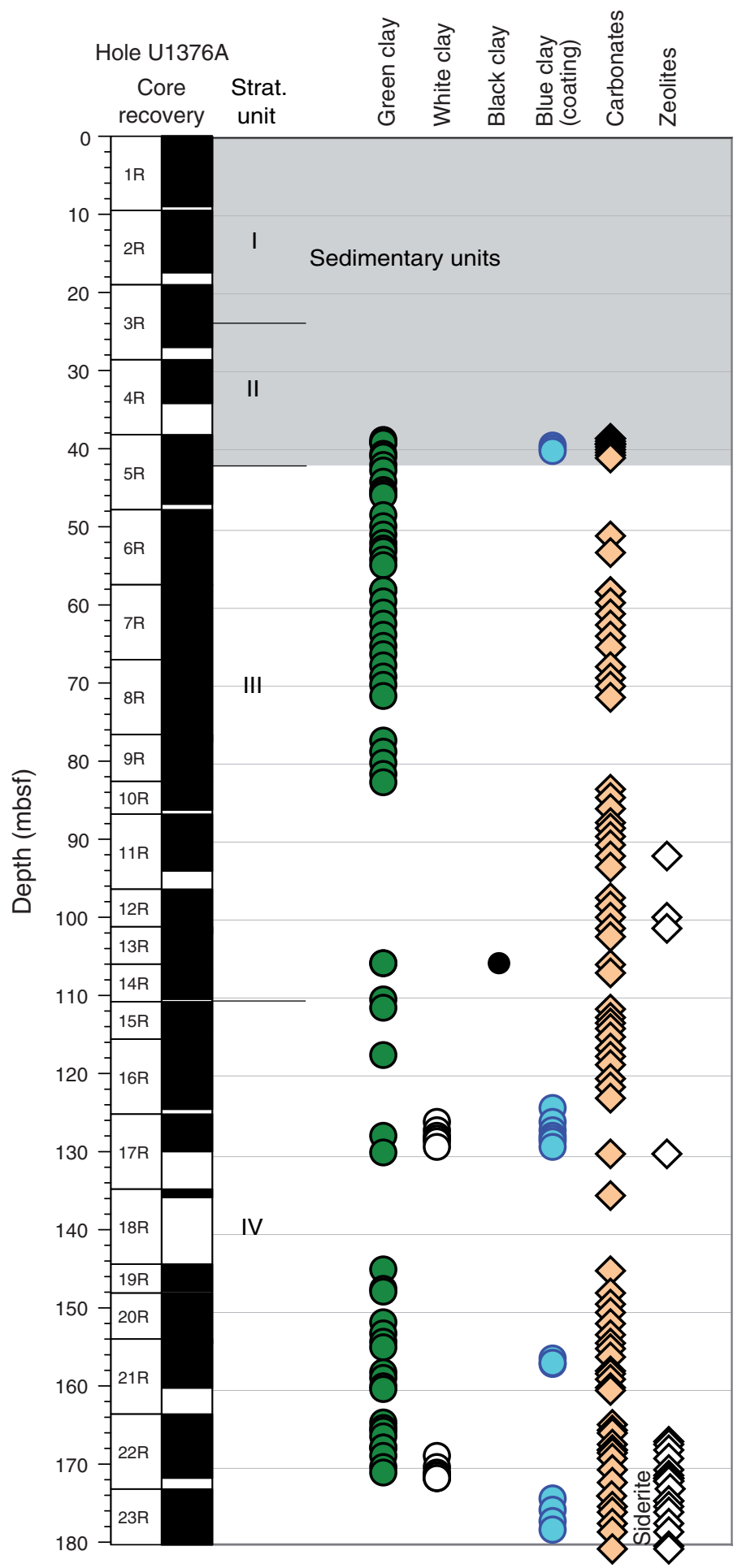


Figure F27. Thin section photomicrographs of vesicles. Each pair is shown under plane-polarized light and with crossed polars. A, B. Vesicle (moderately olivine-augite-phyric pillow basalt) lined with a thin layer of brown clay surrounding carbonates (Sample 330-U1376A-6R-3, 103-106 cm; Thin Section 251). C, D. Vesicles (moderately olivine-augite-phyric pillow basalt) filled with radial saponite along margins surrounding other clay minerals (Sample 330-U1376A-6R-2, 42-46 cm; Thin Section 250). E, F. Vesicle (highly olivine-augitephyric pillow basalt) filled with radial saponite surrounding brown clay with radial habit (Sample 330-U1376A5R-6, 97-99 cm; Thin Section 248).

A

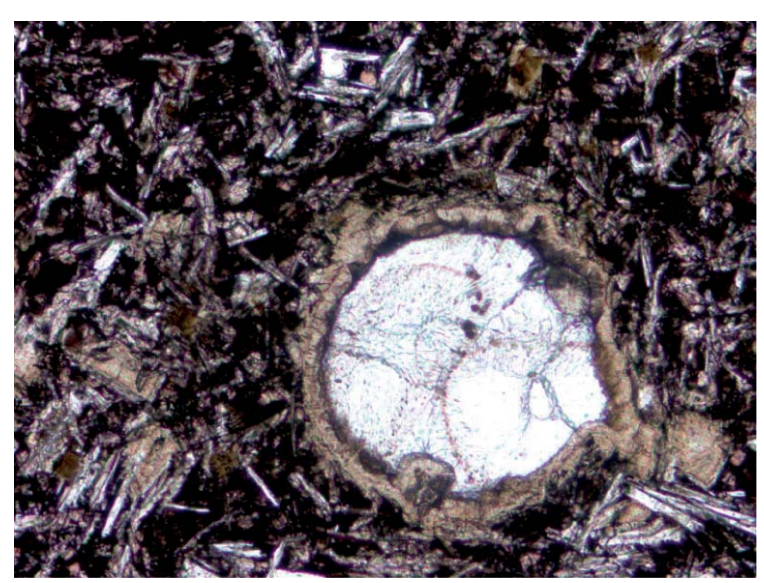

C

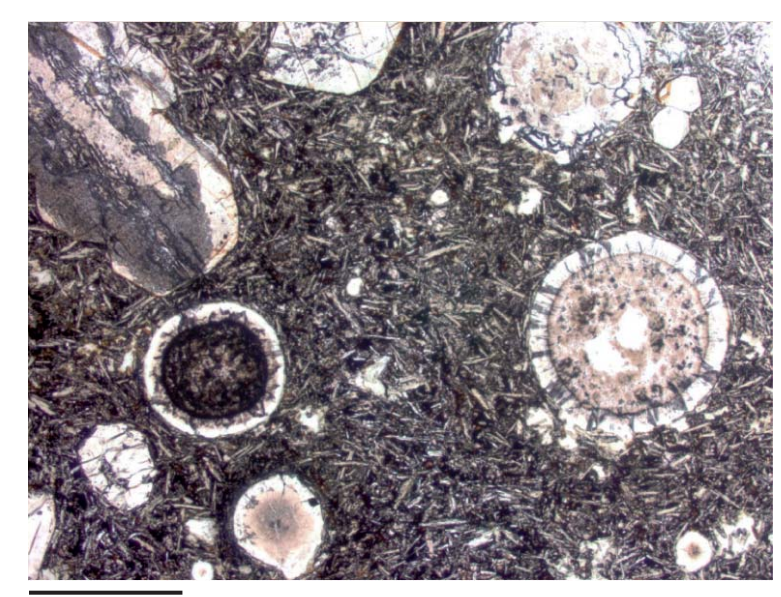

E

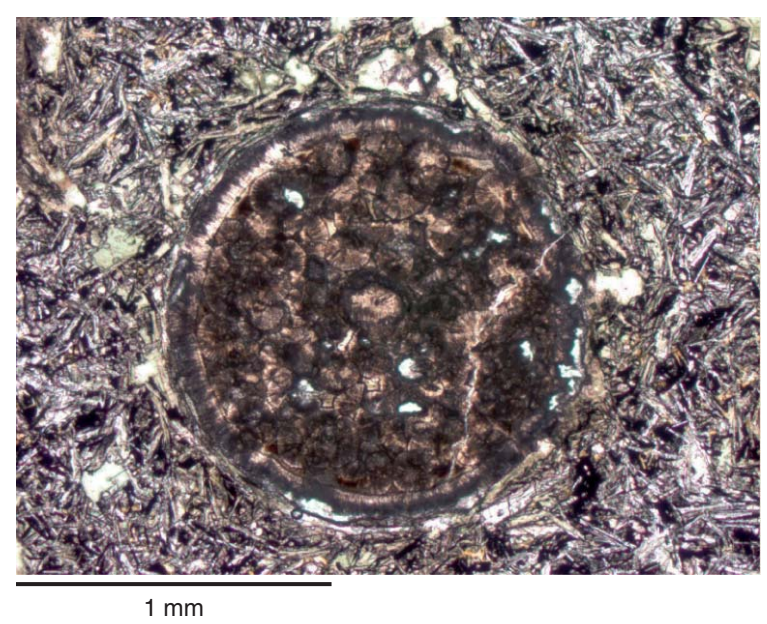

B

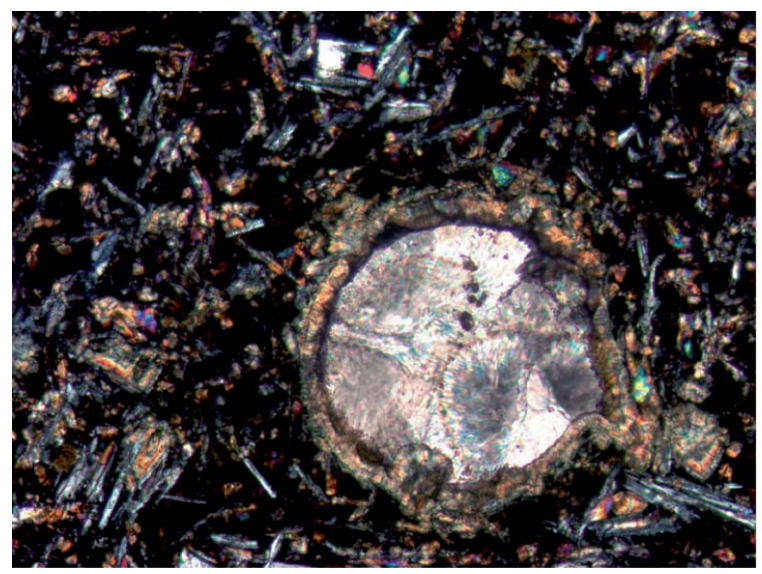

$0.5 \mathrm{~mm}$

D

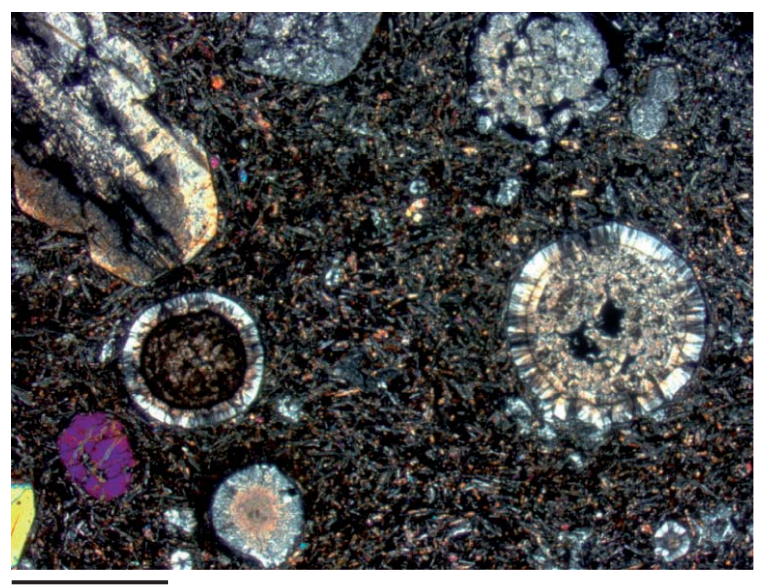

F

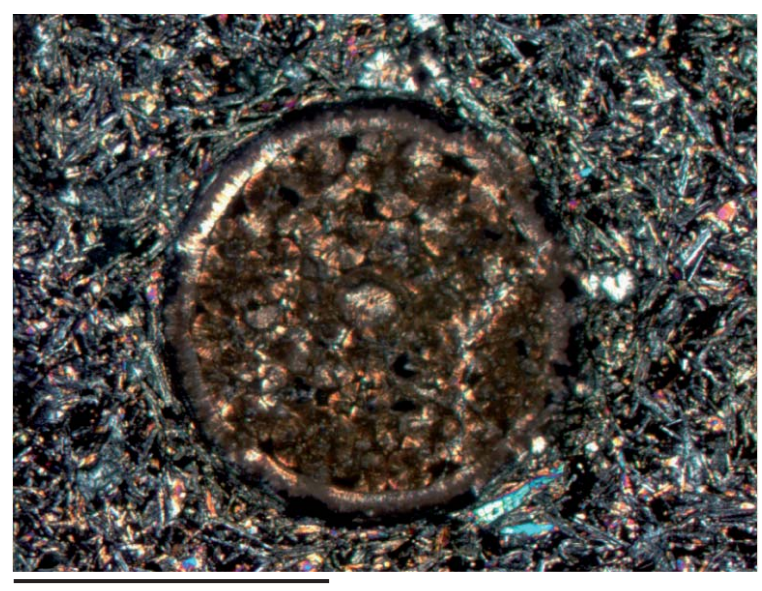

$1 \mathrm{~mm}$ 
Figure F28. Thin section photomicrographs of vesicles. A, B. Vesicle (moderately olivine-augite-phyric pillow basalt) filled first with brown clay and well-crystallized carbonates and later by additional carbonates (Sample 330-U1376A-6R-1, 70-74 cm; Thin Section 249): (A) plane-polarized light, (B) crossed polars. C. Vesicles (highly olivine-phyric basalt) showing multistage infilling with carbonates, green clay, and Fe oxyhydroxides (Sample 330-U1376A-7R-4, 119-122 cm; Thin Section 254; transmitted light). D. Vesicles (highly olivine-phyric basalt) showing filling with brown clay, hematite, and palagonite(?) (Sample 330-U1376A-7R-4, 119-122 cm; Thin Section 254; plane-polarized light). E, F. Vesicles (aphyric basalt intrusive sheet) showing different infilling with green clay and brown clay or hematite (Sample 330-U1376A-15R-2, 37-39 cm; Thin Section 259; plane-polarized light).

A

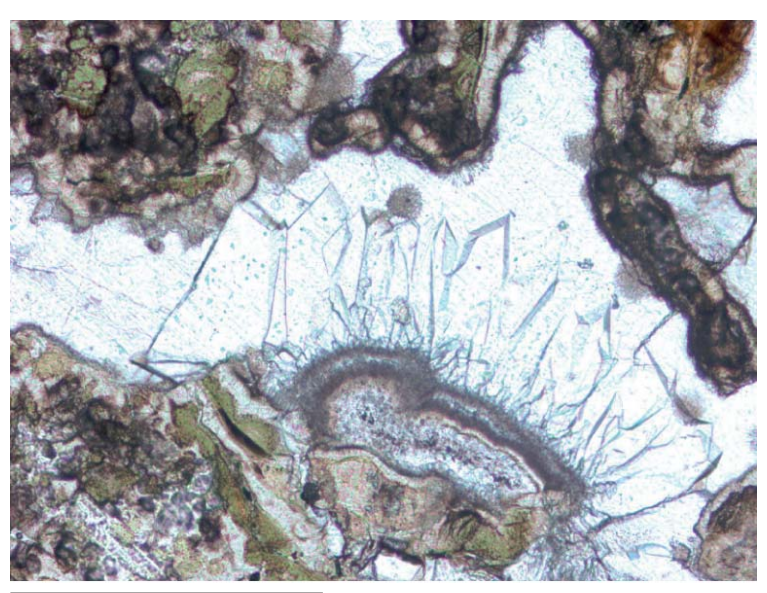

C

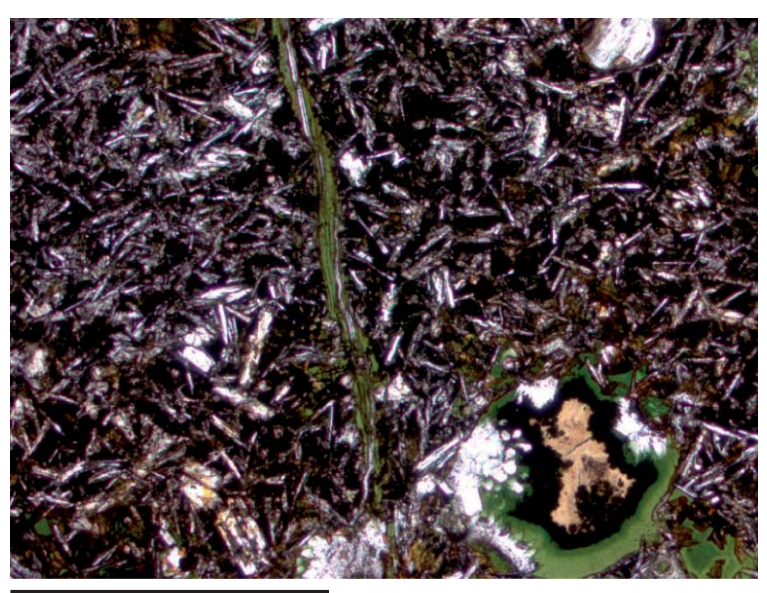

E

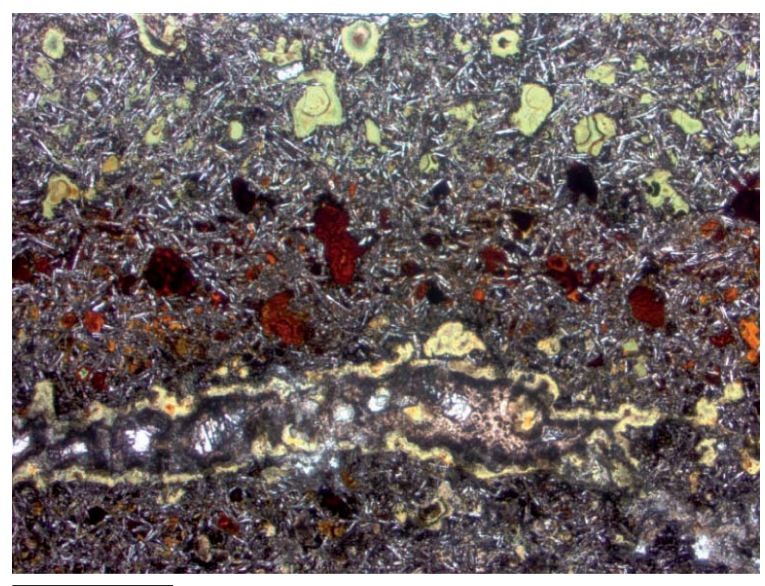

$1 \mathrm{~mm}$
B

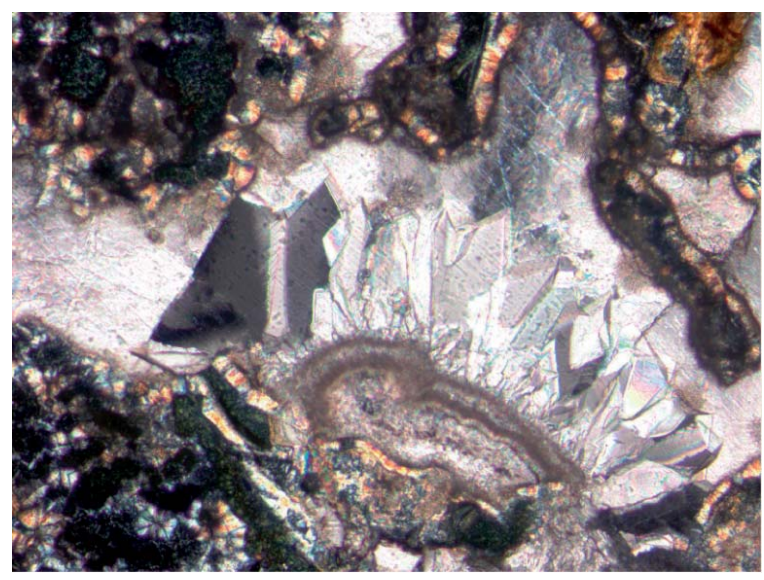

D

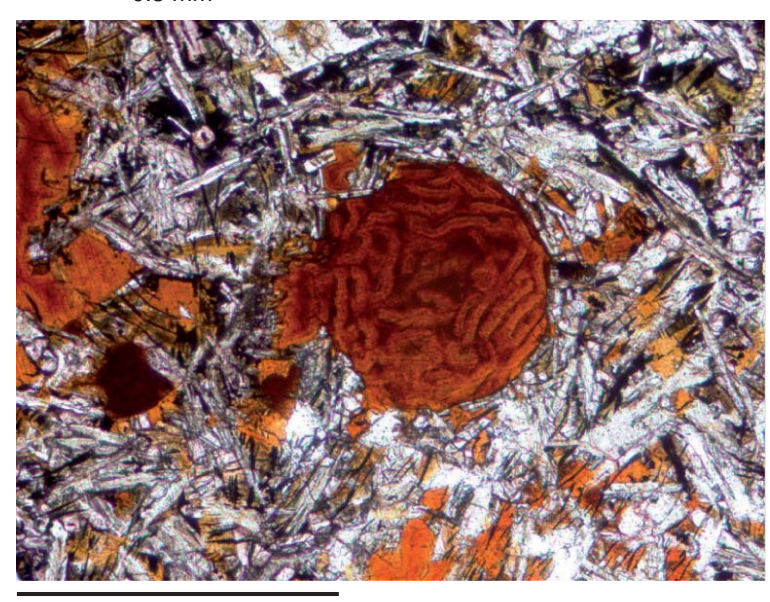

F

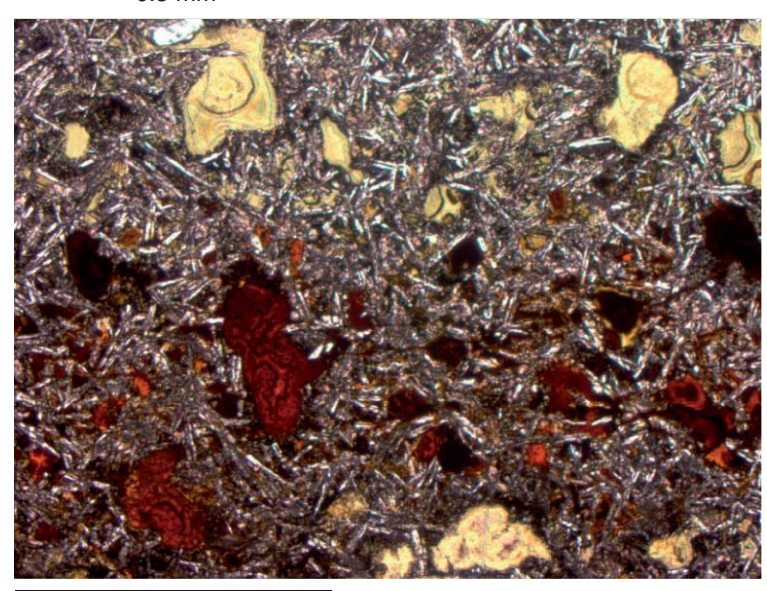

$1 \mathrm{~mm}$ 
Figure F29. Plot of downhole distribution of vein minerals for each alteration interval defined by the alteration petrology group. Symbols are located at center depth for each interval. Gray shading represents sedimentary units.

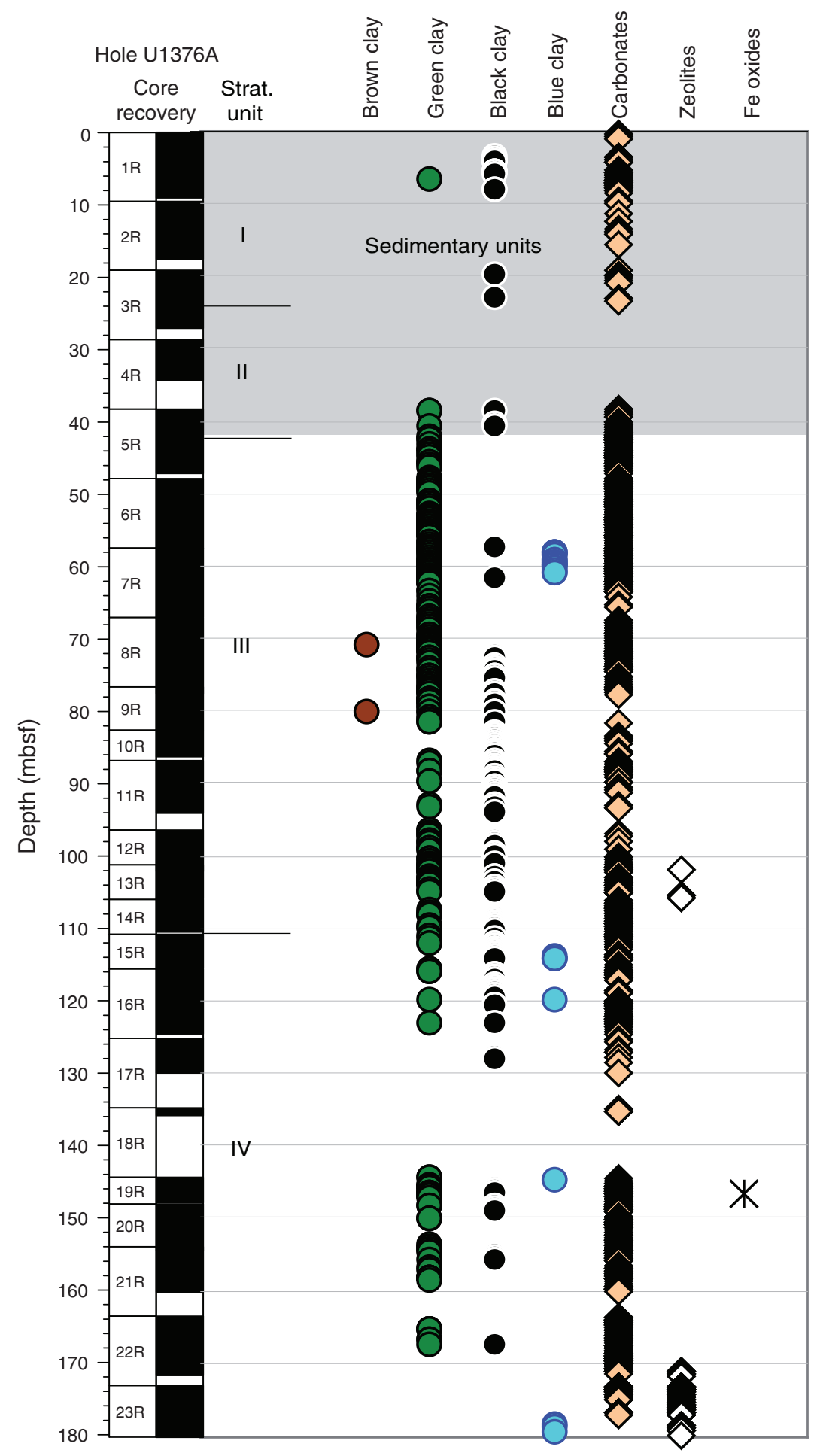


Figure F30. Thin section photomicrographs of veins. A, B. Millimeter-thick veins (highly olivine-phyric basalt clast) filled with fibrous calcite and brown and green clay (Sample 330-U1376A-6R-6, 128-131 cm; Thin Section 253): (A) plane-polarized light, (B) crossed polars. C, D. Submillimeter-thick veins (highly olivine-augite-phyric massive basalt) filled with fibrous calcite and green clay (Sample 330-U1376A-14R-3, 84-86 cm; Thin Section 258): (C) plane-polarized light, (D) crossed polars. E. Millimeter-thick vein (highly olivine-phyric basalt clast) crosscutting altered olivine and filled with fibrous carbonate (Sample 330-U1376A-6R-4, 119-122 cm; Thin Section 252; plane-polarized light).

A

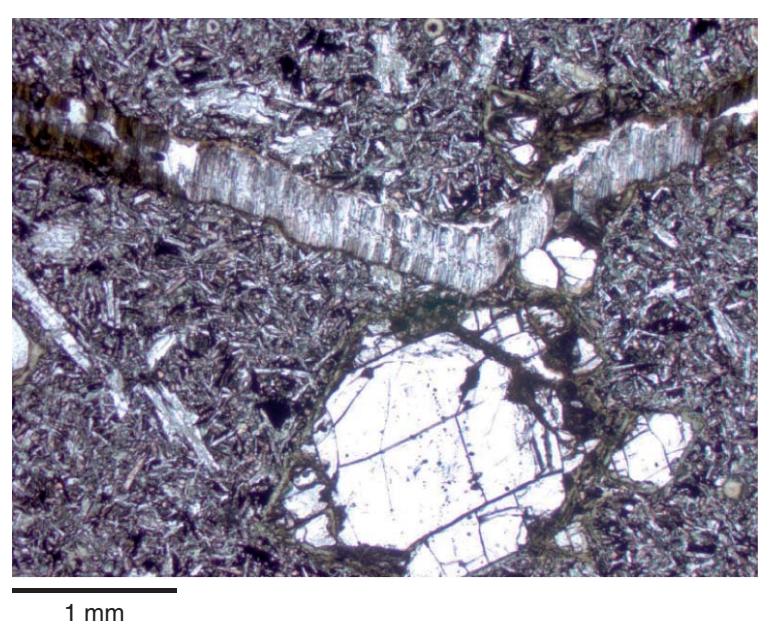

C

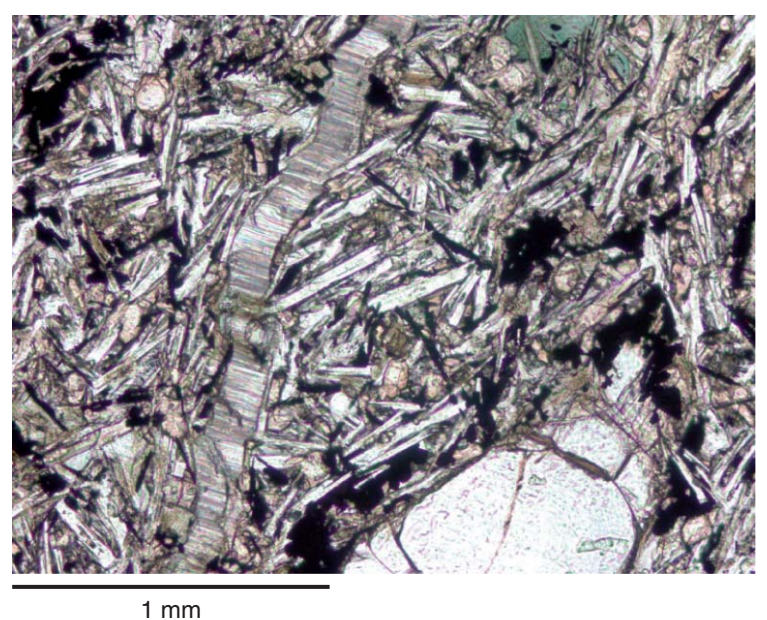

$\mathbf{E}$

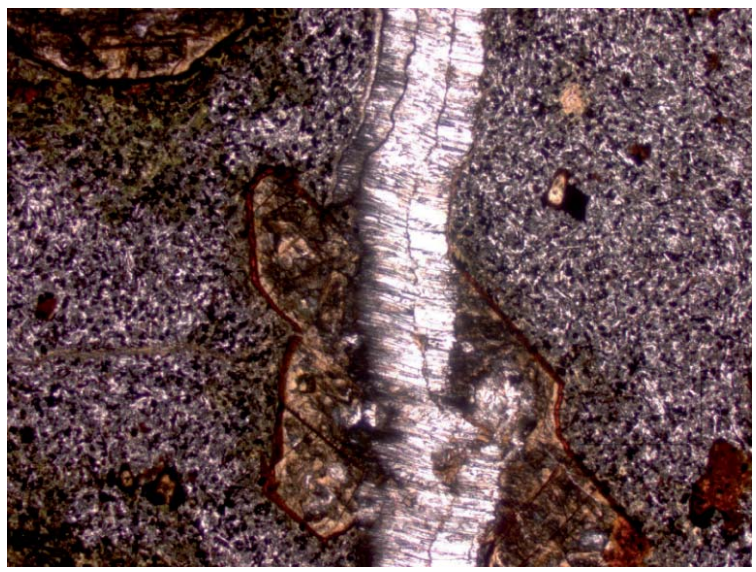

$1 \mathrm{~mm}$
B

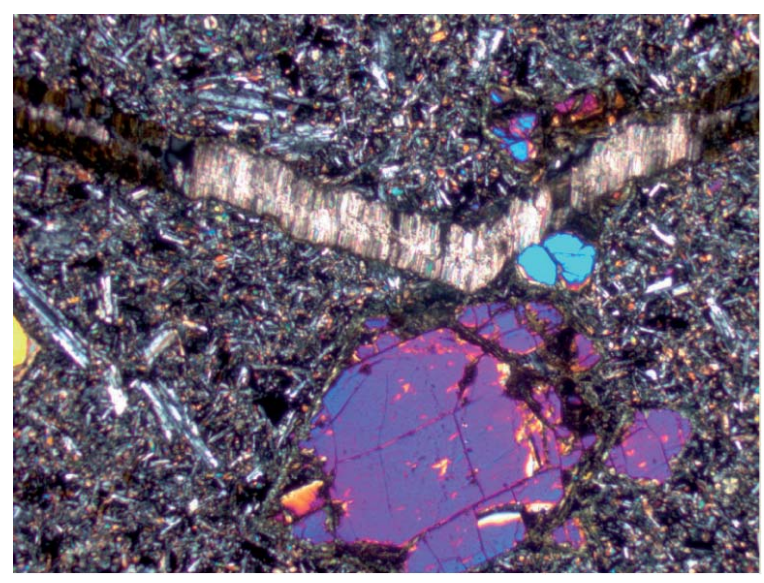

$1 \mathrm{~mm}$

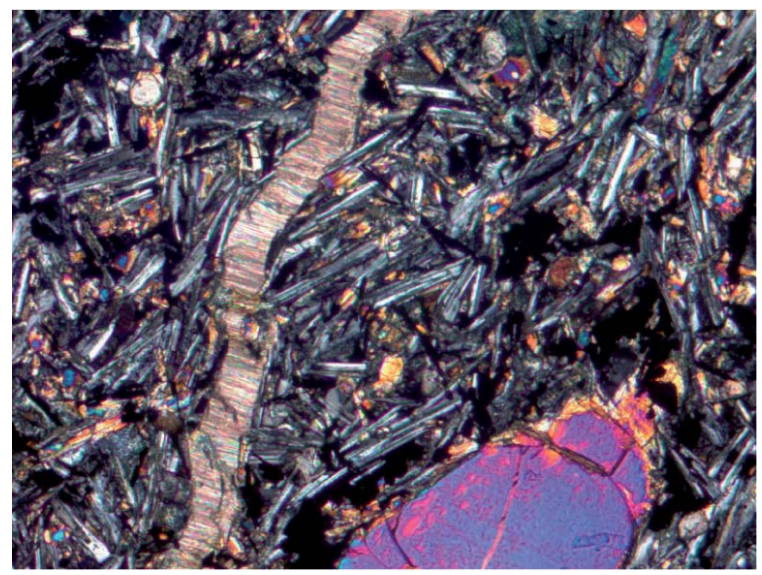

$0.5 \mathrm{~mm}$ 
Figure F31. Number of structural features, Hole U1376A, representing total number of features with individual row entries in DESClogik database entry form. For veins, and especially vein networks, a single entry may comprise multiple features (e.g., 12 veinlets in a vein network). When multiple features are considered, there are 1489 individual veins and 1995 veinlets within networks in Hole U1376A.

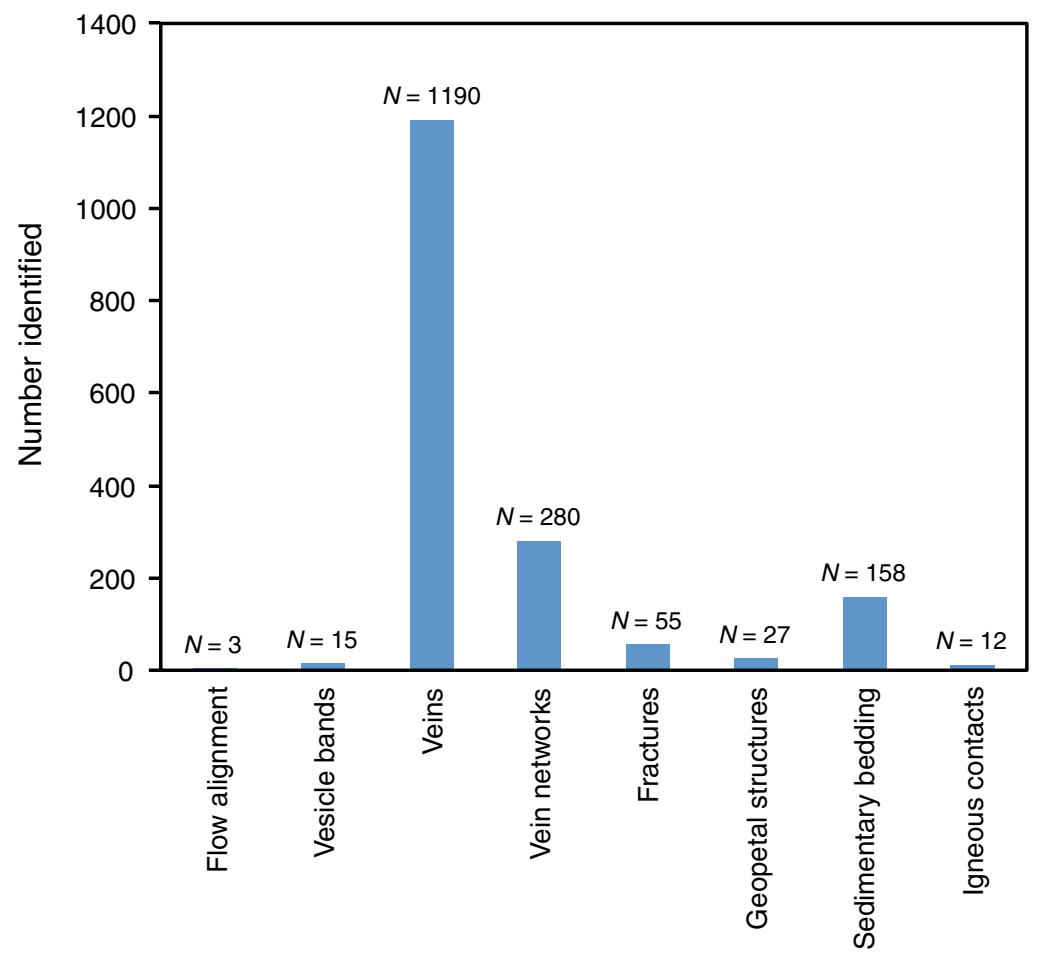


Figure F32. Distribution of veins and vein networks, Hole U1376A. Veins are abundant in all units, including rheologically hard lava flows, breccia, and hyaloclastites. For explanation of lithology symbols, see Figure F10.

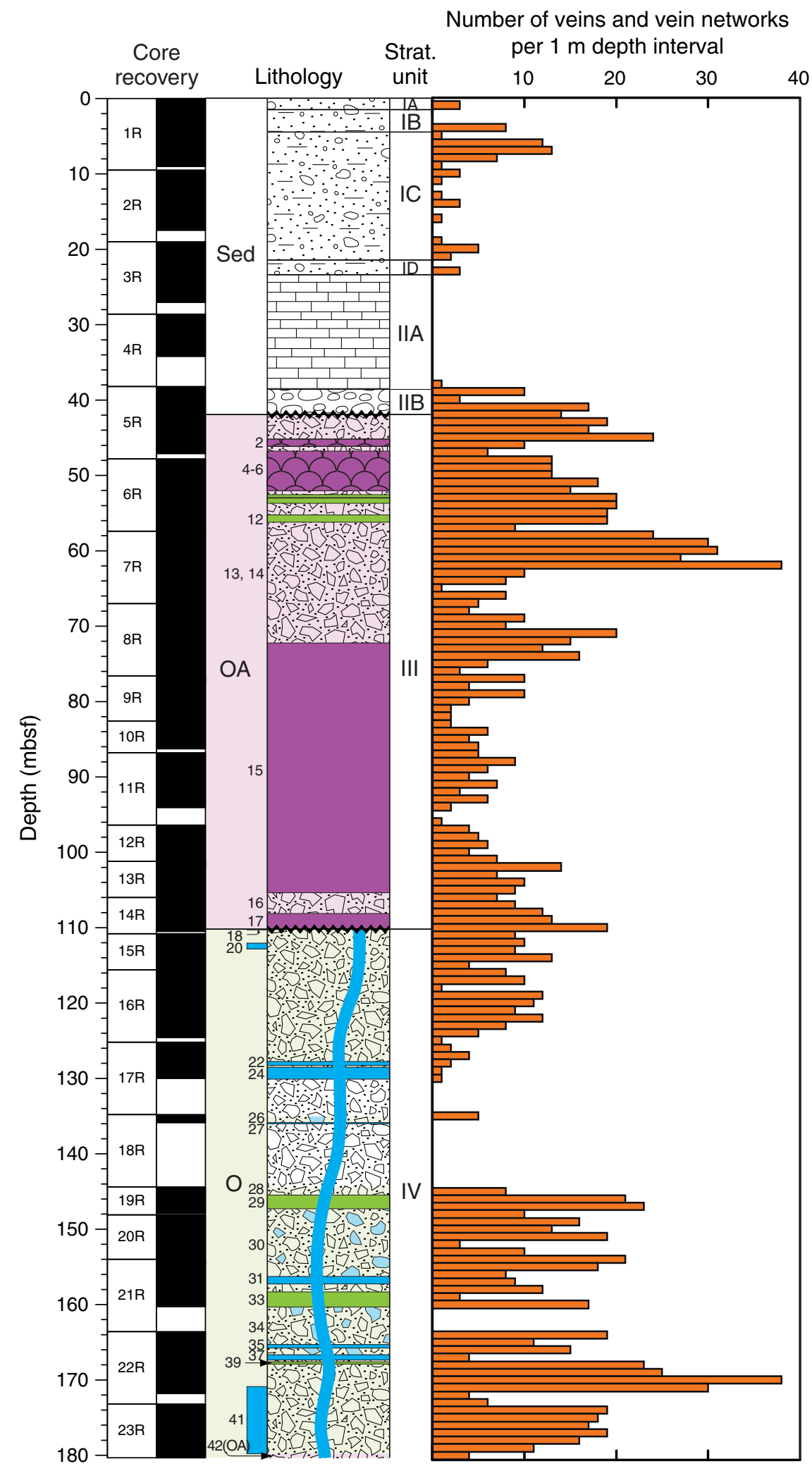


Figure F33. Rose diagrams showing dip angles of structures in Hole U1376A relative to the core reference frame. A. Sedimentary beds are dominantly shallowly dipping, with a maximum at $15^{\circ}$. B. The seven chilled contacts measured from flows and intrusions have a broad range of dips from $14^{\circ}$ to $80^{\circ}$. C, D. Veins and vein networks are dominantly shallowly dipping, with veins having a pronounced maximum at $20^{\circ}-25^{\circ}$ and vein networks having a maximum at $10^{\circ}-15^{\circ}$. E. Lithologic Unit 41 (dike) has a substantially different vein pattern compared to the dominantly shallowly dipping veins found elsewhere in Hole U1376A. F. The few fractures in Hole $\mathrm{U} 1376 \mathrm{~A}$ have dominantly moderate to shallow dips, with a maximum at $25^{\circ}-30^{\circ}$.
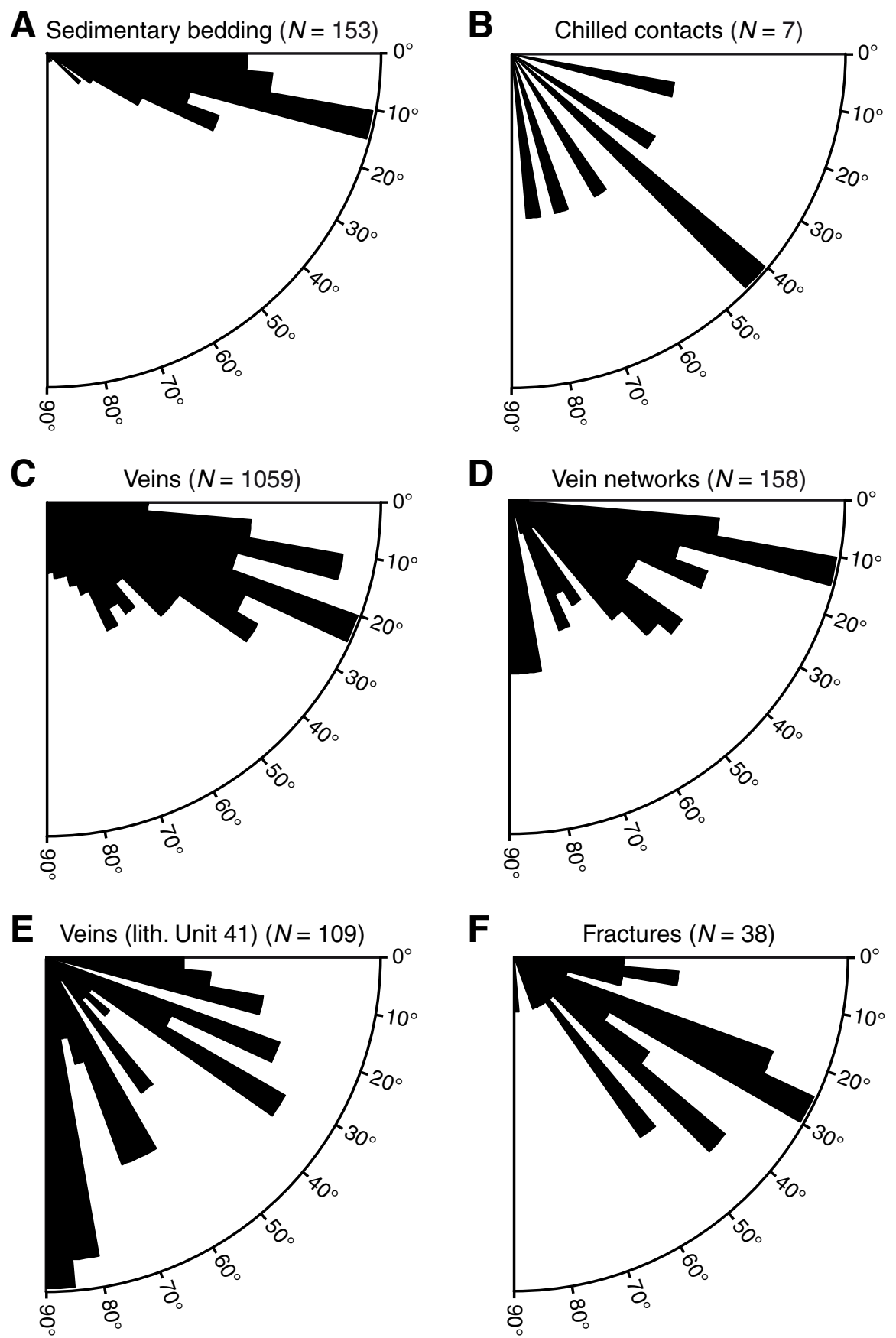
Figure F34. Representative core photographs of veins, Hole U1376A, showing the commonly stepped habit of veins. A. Veins in hyaloclastite of upper parts of Unit III are dominantly subhorizontal $(N=7)$ with a single steeply dipping vein (interval 330-U1376A-5R-5A, 40-55 cm). B. Six subhorizontal stepped veins and no vertical veins, slightly lower in Unit III (interval 6R-4A, 0-18 cm). C. One of the densest concentrations of veins at Burton Guyot, again with dominantly subhorizontal features (interval 6R-4A, 108-131 cm). D. Excellent example of a stepped vein, particularly on the right-hand side of the core (interval 7R-2A, 68-72 cm). E. Dense concentration of veins, with nine veins $5-10 \mathrm{~mm}$ wide (interval 7R-4A, $24-58 \mathrm{~cm}$ ). F. One of the widest veins in Hole U1376A (interval 21R-3A, 54-61 cm). G. Subvertical and subhorizontal veins located a few meters above the large dike of lithologic Unit 41 (interval 22R-5A, 59-84 cm). Most of the veins in A-G have subvertical growth of cross fibers, but these fibers are more apparent in thin section images (Fig. F35).

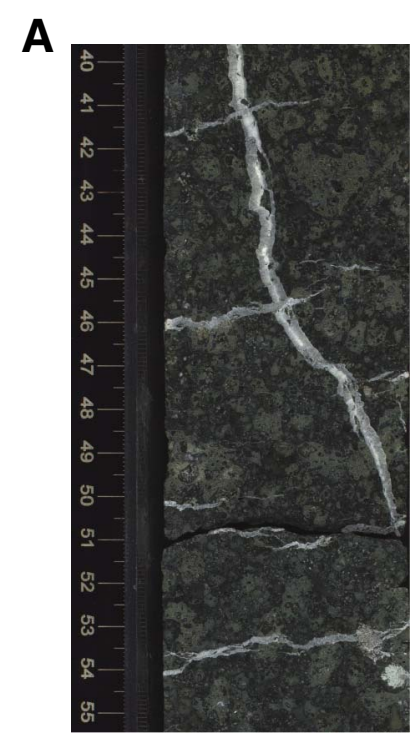

B

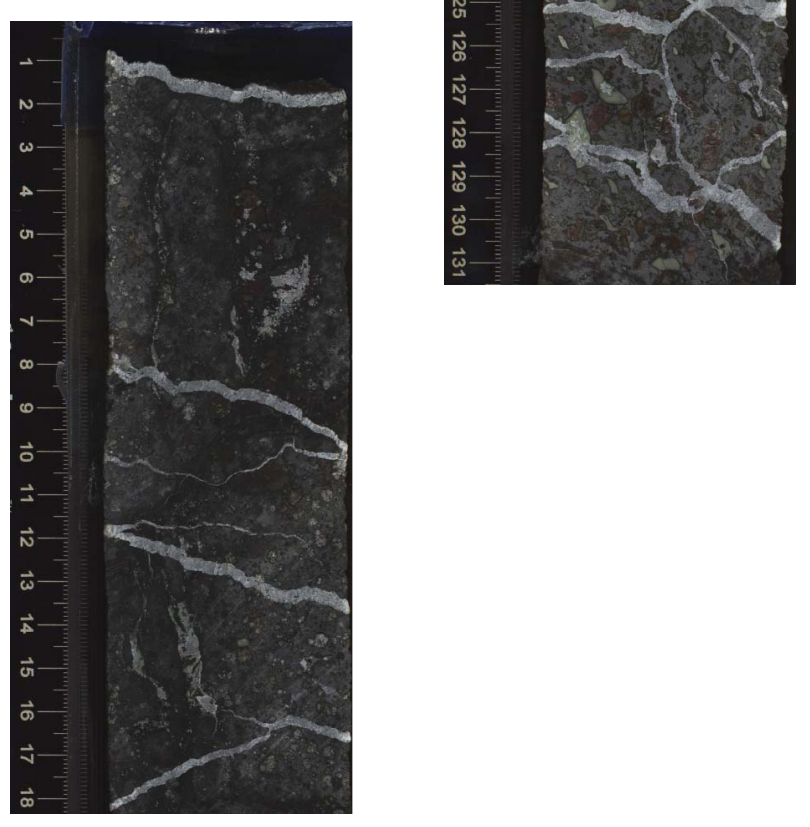

C

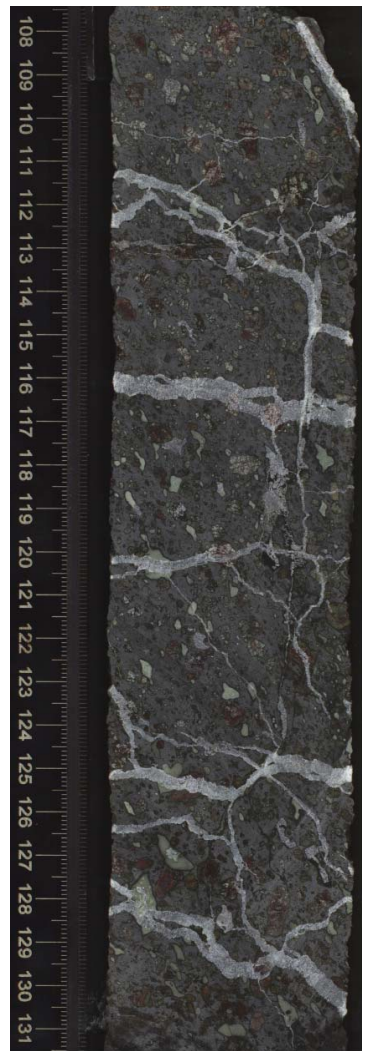

D

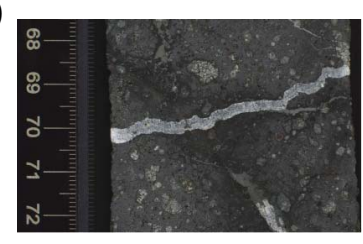

E

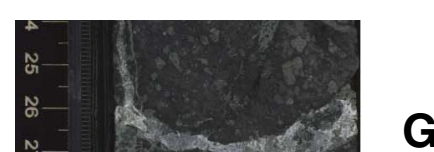

$\mathbf{F}$

G
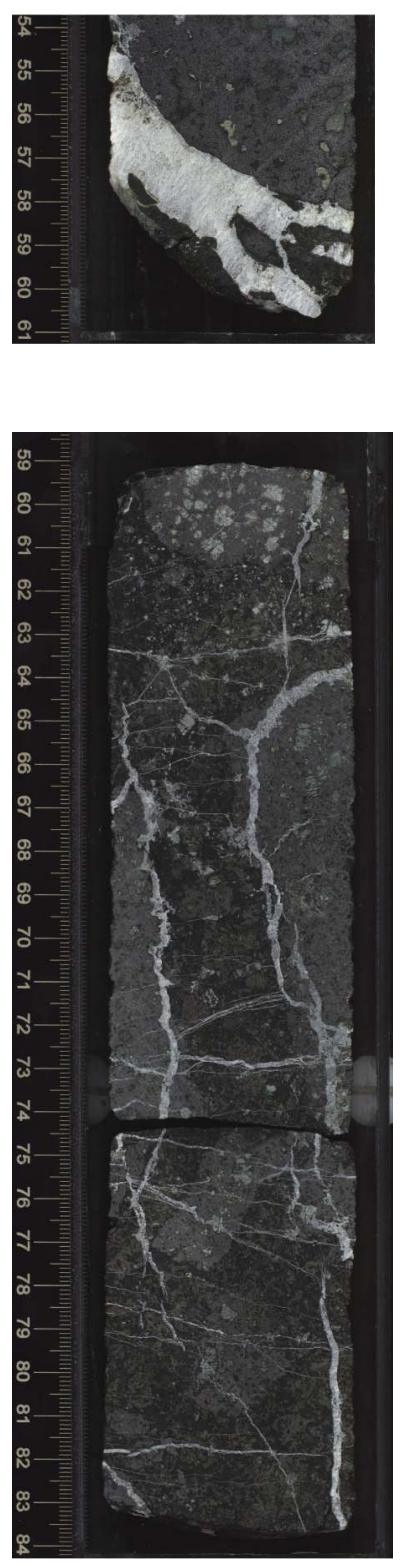
Figure F35. Representative thin section photomicrographs of veins, Hole U1376A. A, B. Early carbonate vein containing uniform crystals, crosscut by a later vein containing cross fibers (Sample 330-U1376A-6R-4W, 119$122 \mathrm{~cm}$; Thin Section 252). This thin section is not oriented, so it is not possible to determine the direction of vein opening. In B the vein containing cross fibers crosscuts an altered olivine crystal. The two sides of the olivine crystal have been displaced in the same orientation as mineral fiber growth. C, D. Oriented thin section (black arrow points toward top of core) from upper part of the $33.11 \mathrm{~m}$ thick olivine and pyroxene-phyric flow in Unit III (Sample 330-U1376A-8R-6W, 136-140 cm; Thin Section 255): (C) plane-polarized light, (D) crossed polars. The direction of mineral fiber growth shows the direction of vein opening (Ramsay and Huber, 1987) and indicates the vein opened in two pulses, one with a near-vertical displacement and a later opening in a slightly inclined direction.

A

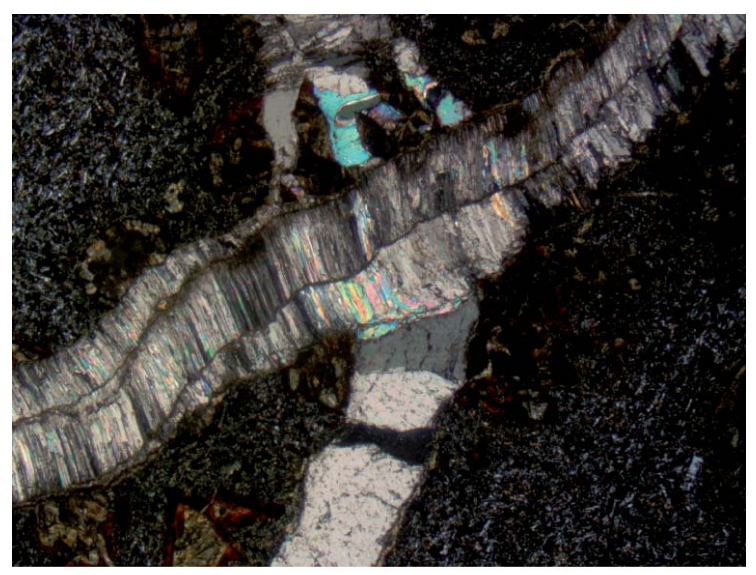

$1 \mathrm{~mm}$

C

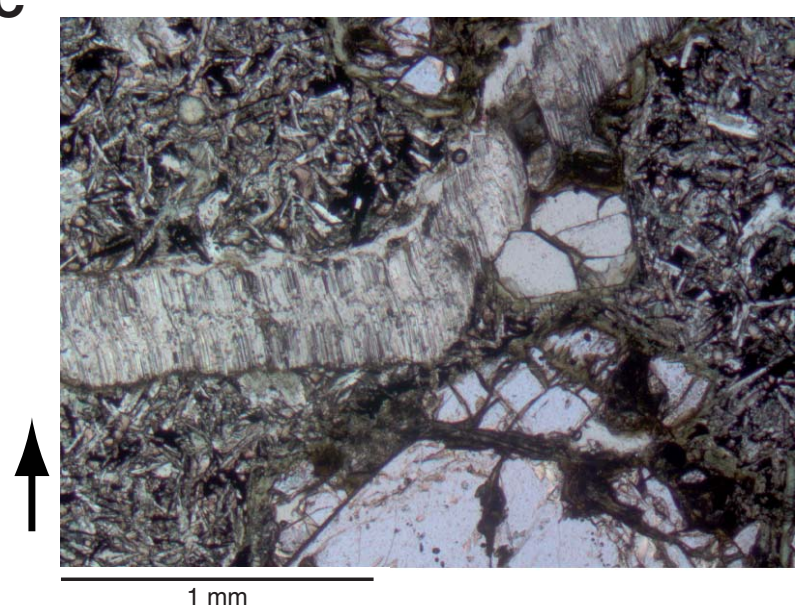

B

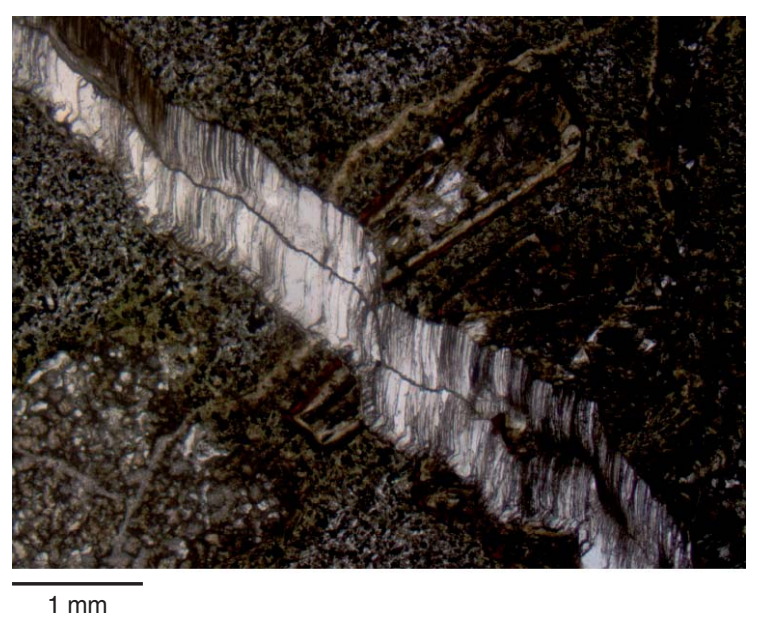

D

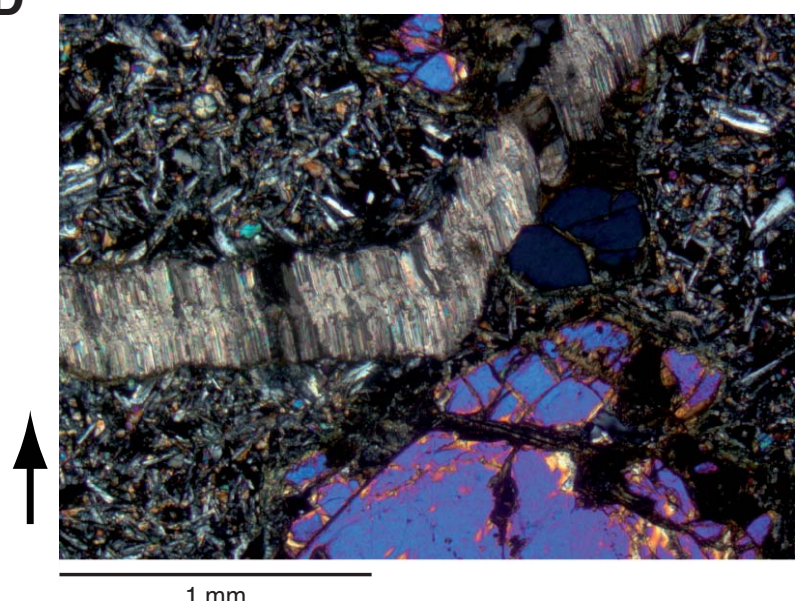


Figure F36. Distribution of fractures, Hole U1376A. The fractures are mostly contained in rheologically hard units (lava flows and intrusive sheets) and are scarce to nonexistent in breccia units. For explanation of lithology symbols, see Figure F10.

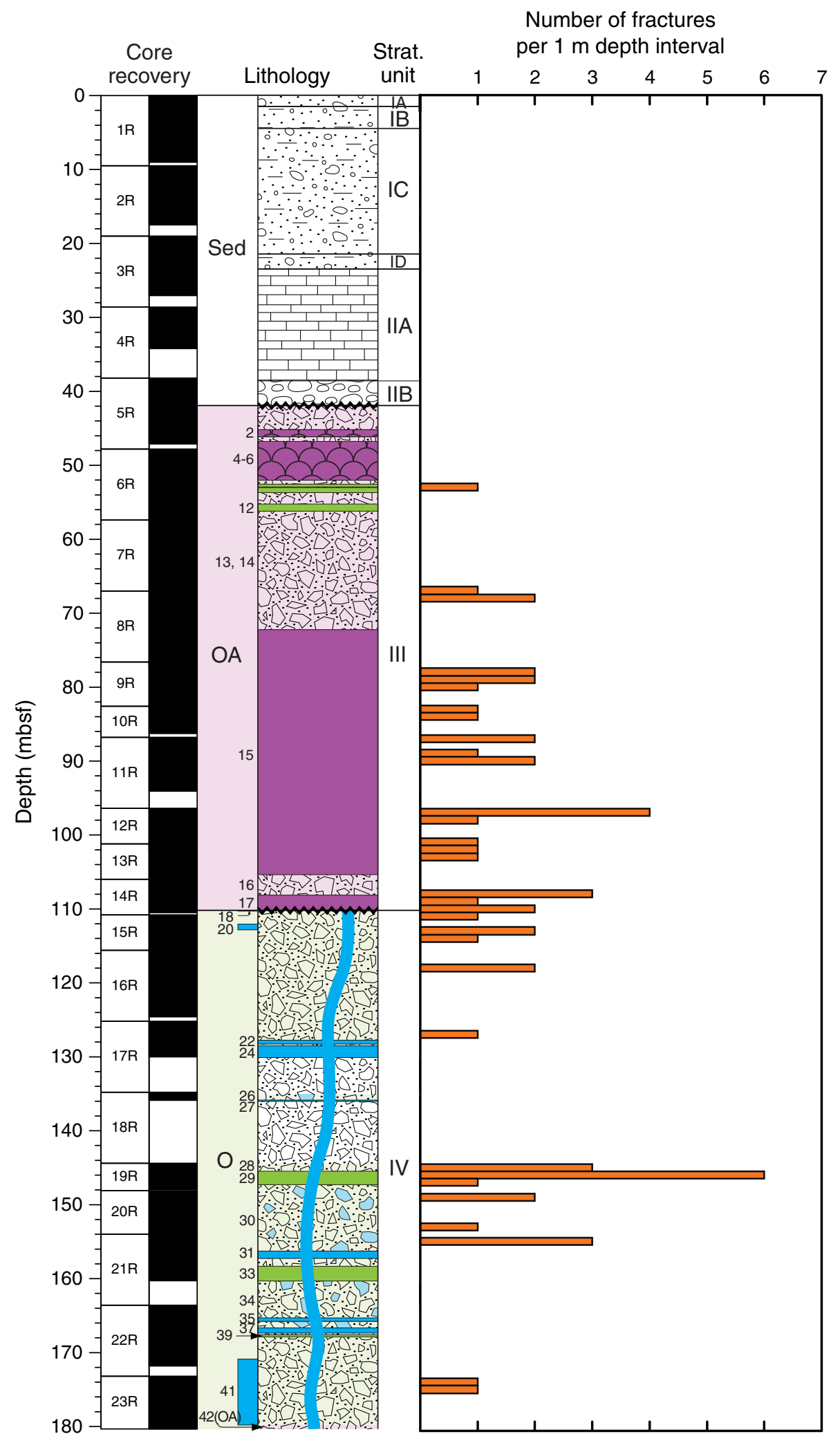


Figure F37. (A) Core recovery and stratigraphy of Hole U1376A, with (B, C) representative close-up core photographs of geopetal structures. (B) Numerous horizontal geopetal structures within limestone of Subunit IIA (interval 330-U1376A-4R-3A, 3-8 cm [wet]). These geopetals have a pink micrite lower layer, with the remainder subsequently completely or partially filled by calcite. (C) Geopetals within this large clast have dips of up to $8^{\circ}$ on either side of horizontal, resulting in an overall average of $\sim 0^{\circ}$ (interval $5 \mathrm{R}-1 \mathrm{~A}, 78.8-84.5 \mathrm{~cm}$ [dry]). For explanation of lithology symbols, see Figure F10.

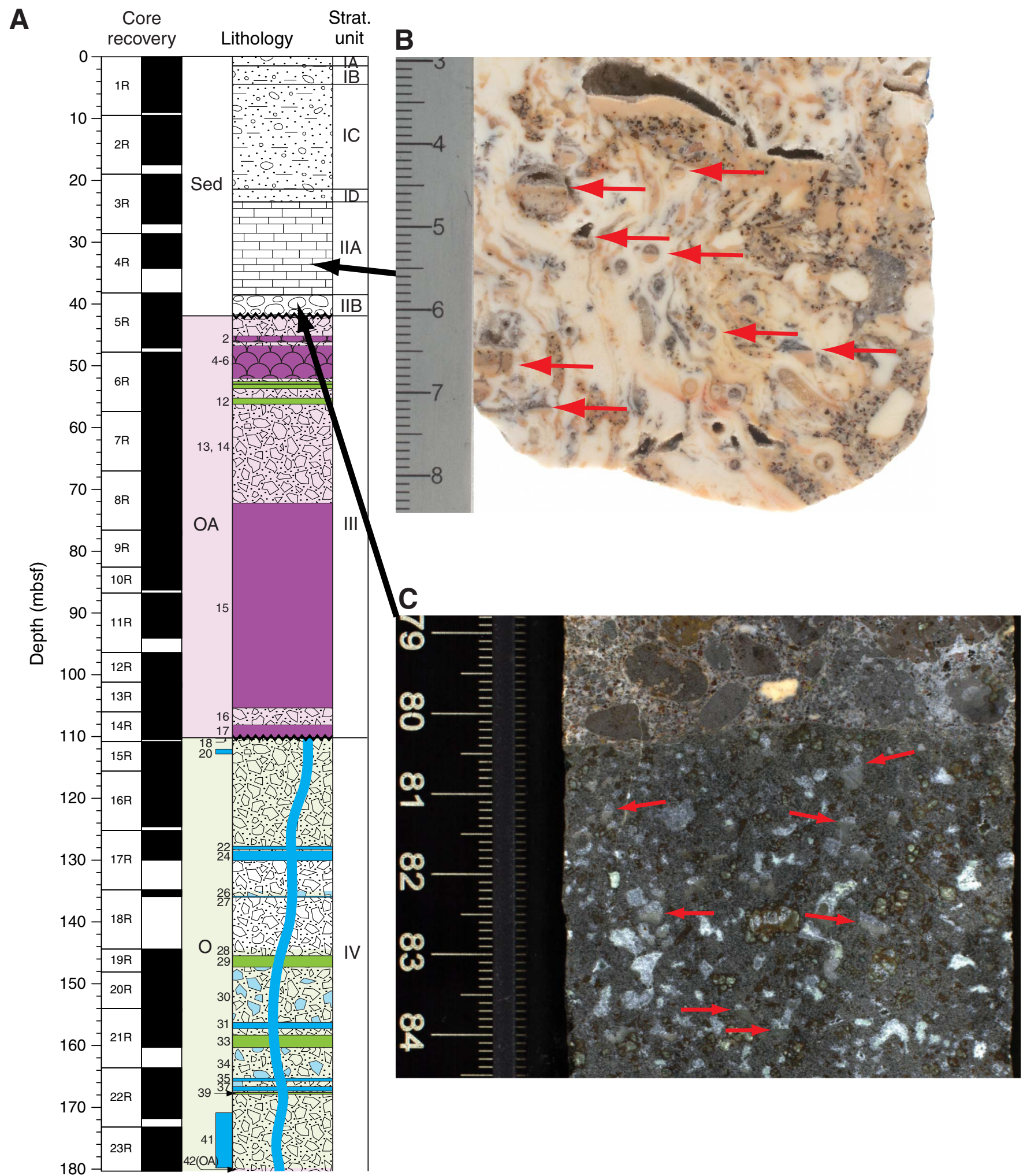


Figure F38. Total alkalis vs. silica for Sites U1372-U1377, with Le Maitre et al.'s (1989) classification of volcanic rock types. The dashed line divides data for tholeiitic and alkalic rocks of Hawaii (Macdonald and Katsura, 1964; Macdonald, 1968). Expedition 330 data are normalized to $100 \mathrm{wt} \%$ totals. Shown for comparison are data for dredge samples from the length of the Louisville Seamount Trail (only data for dredge samples with LOI $<6$ wt $\%$ are included; data of Hawkins et al., 1987; Vanderkluysen et al., 2007; Beier et al., 2011). Also shown are fields for the southern East Pacific Rise (EPR; data of Sinton et al., 1991; Bach et al., 1994; Mahoney et al., 1994) and Ontong Java Plateau (OJP; data of Tejada et al., 1996, 2002; Fitton and Godard, 2004).

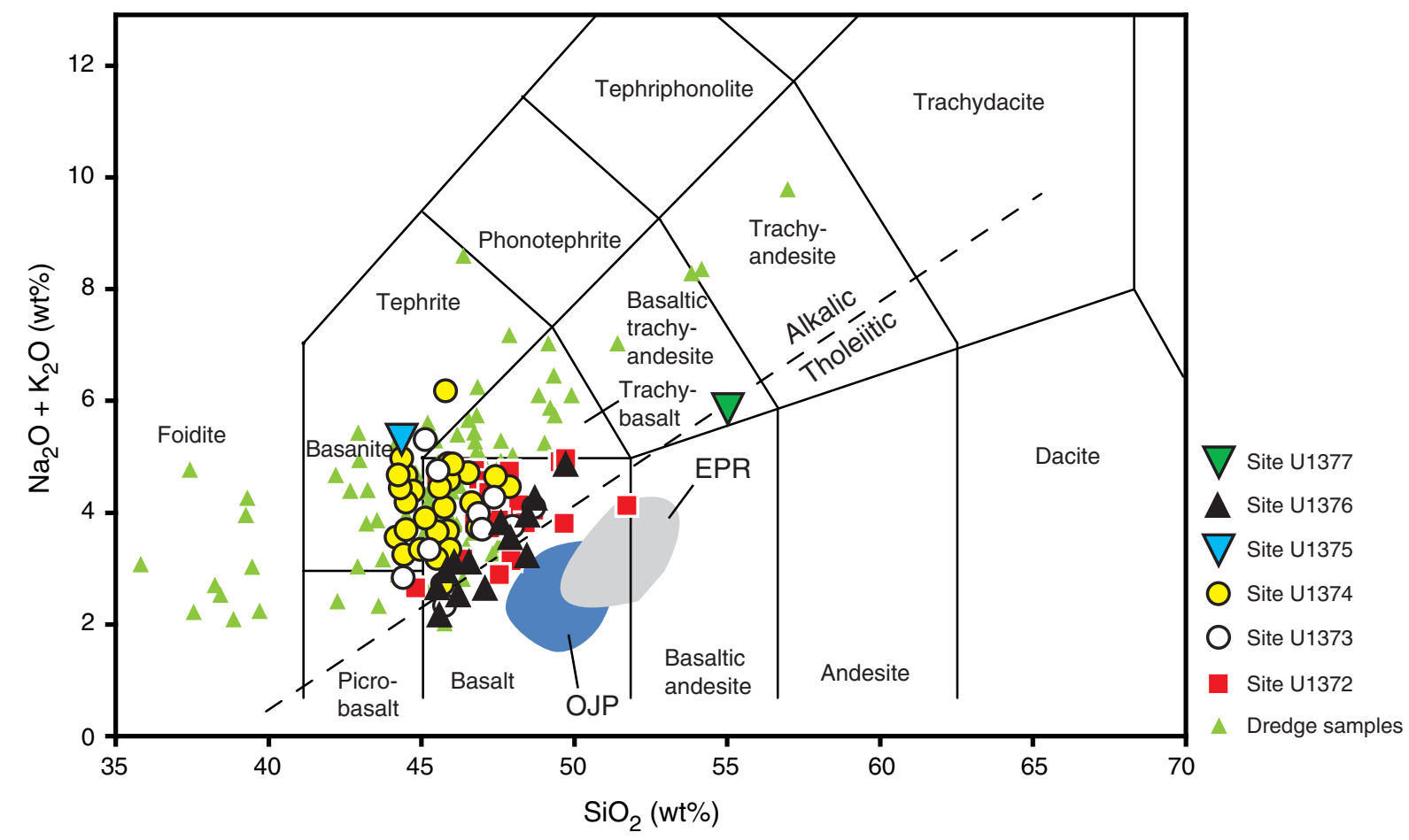


Figure F39. $\mathrm{MgO}$ vs. (A) $\mathrm{Al}_{2} \mathrm{O}_{3},(\mathbf{B}) \mathrm{CaO} / \mathrm{Al}_{2} \mathrm{O}_{3}$, and (C) $\mathrm{Fe}_{2} \mathrm{O}_{3}{ }^{\top}$ for Sites U1372-U1377. Expedition 330 data are normalized to $100 \mathrm{wt} \%$ totals. Data for dredge samples include only samples with $\mathrm{LOI}<6 \mathrm{wt} \%$ (data of Hawkins et al., 1987; Vanderkluysen et al., 2007; Beier et al., 2011). Fields for several Hawaiian volcanoes are shown. "Hawaii shield" fields are for Mauna Kea (blue line), Mauna Loa (green line), and Kilauea (red line) (data of Lipman et al., 1990; Frey et al., 1991; Moore and Clague, 1992; Clague et al., 1995; Rhodes and Hart, 1995; Garcia et al., 2003). "Hawaii postshield" fields include Lapahoehoe and Hamakua lavas (data of Frey et al., 1990; West et al., 1988). Also shown are fields for the southern East Pacific Rise (EPR; data of Sinton et al., 1991; Bach et al., 1994; Mahoney et al., 1994) and Ontong Java Plateau (OJP; data of Tejada et al., 1996, 2002; Fitton and Godard, 2004).

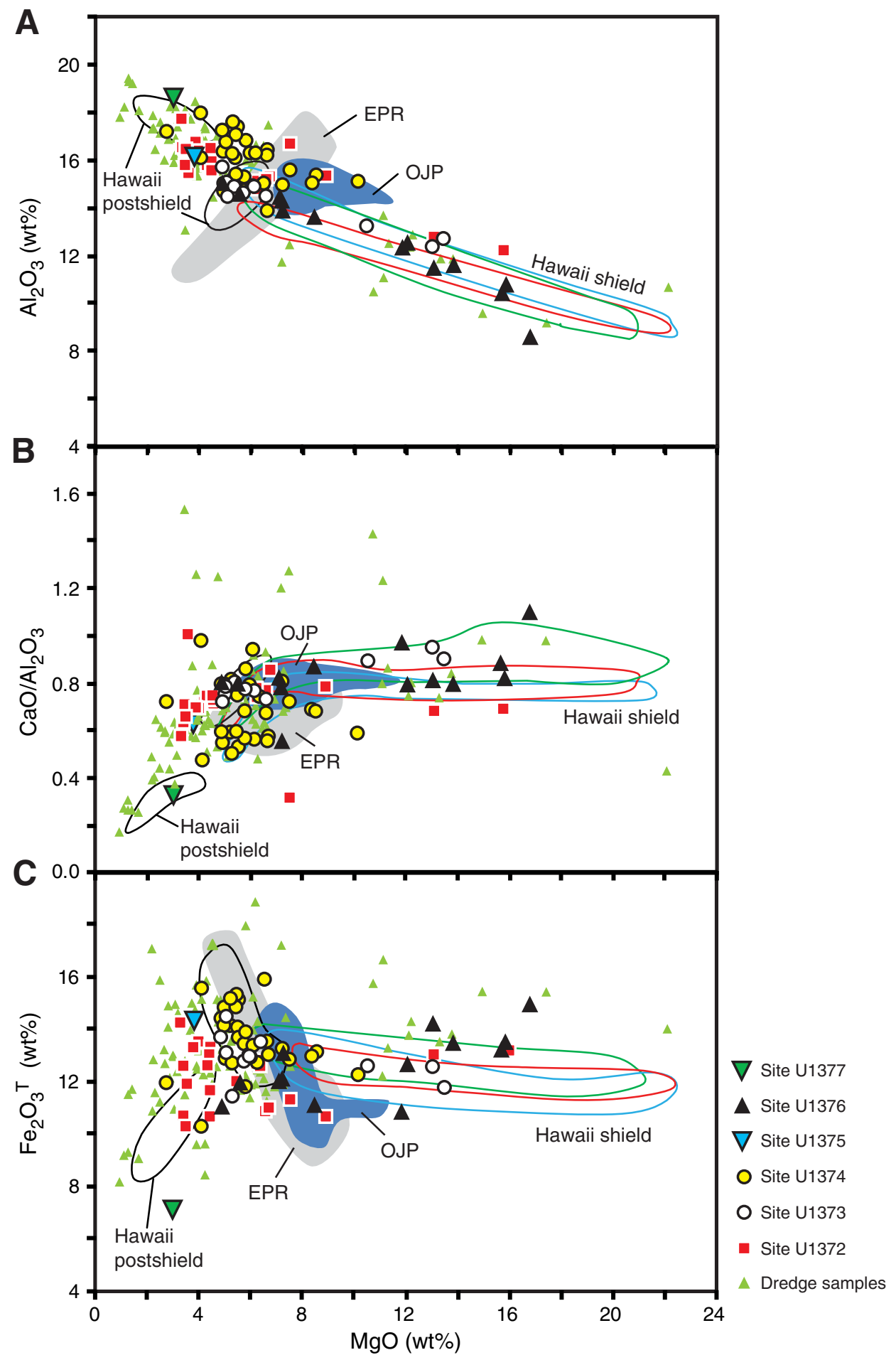


Figure F40. $\mathrm{TiO}_{2}$ vs. (A) Ba, (B) Sr, (C) $\mathrm{P}_{2} \mathrm{O}_{5}$, and (D) $\mathrm{Y}$ for Sites U1372-U1377. Note that major element data for Expedition 330 are normalized to $100 \mathrm{wt} \%$ totals. Data for dredge samples from the Louisville Seamount Trail include only samples with LOI < $6 \mathrm{wt} \%$ (data of Hawkins et al., 1987; Vanderkluysen et al., 2007; Beier et al., 2011). Fields for several Hawaiian volcanoes are shown. "Hawaii shield" fields are for Mauna Kea (blue line), Mauna Loa (green line), and Kilauea (red line) (data of Lipman et al., 1990; Frey et al., 1991; Moore and Clague, 1992; Clague et al., 1995; Rhodes and Hart, 1995; Garcia et al., 2003). "Hawaii postshield" fields include Lapahoehoe and Hamakua lavas (data of Frey et al., 1990; West et al., 1988). Also shown are fields for the southern East Pacific Rise (EPR; data of Sinton et al., 1991; Bach et al., 1994; Mahoney et al., 1994) and Ontong Java Plateau (OJP; data of Tejada et al., 1996, 2002; Fitton and Godard, 2004).

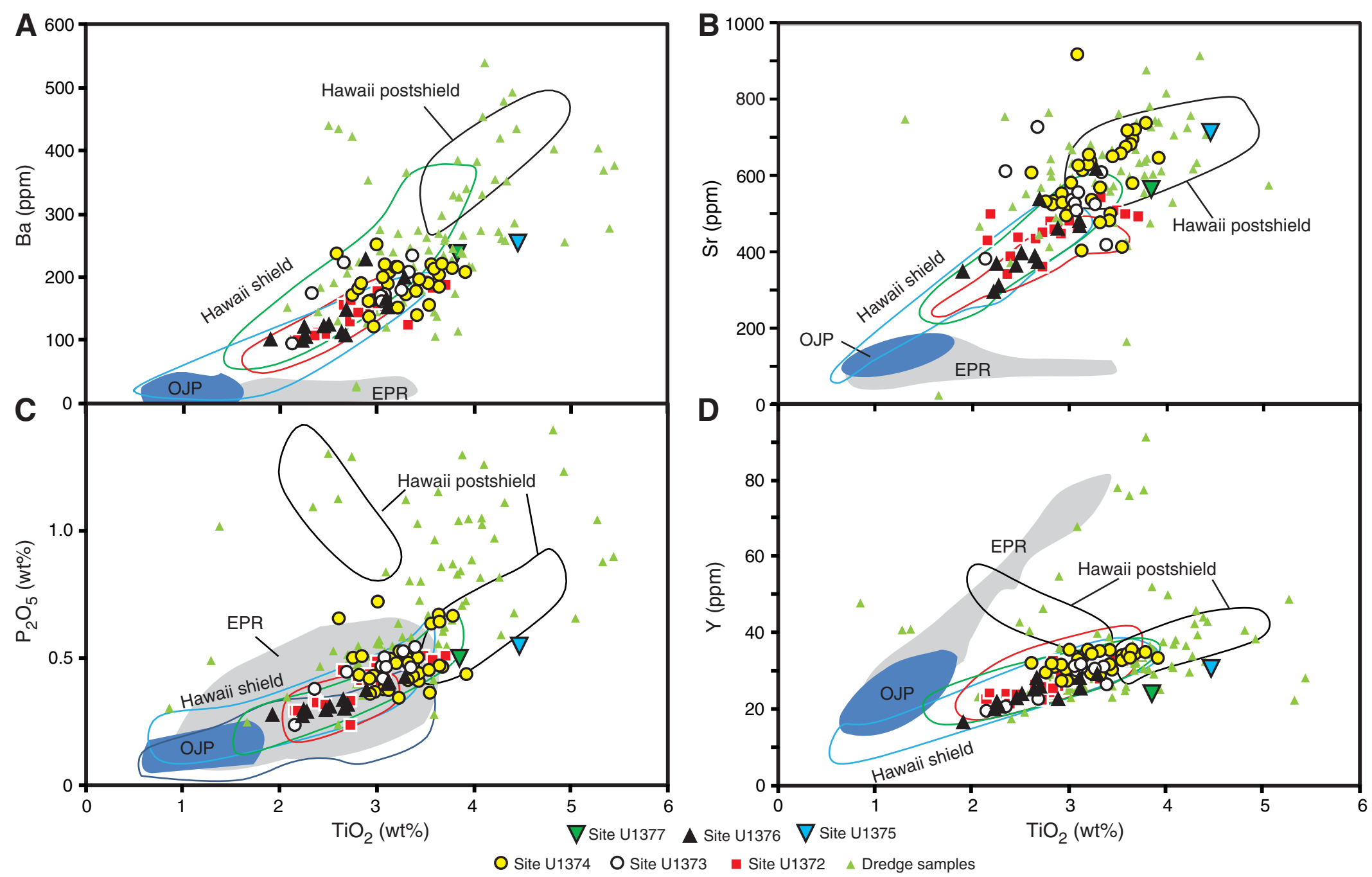


Figure F41. Downhole variation of (A) $\mathrm{Mg \# ,} \mathrm{(B)} \mathrm{Ni},(\mathbf{C}) \mathrm{TiO}_{2},(\mathbf{D}) \mathrm{Zr} / \mathrm{Y}$, and (E) $\mathrm{Ba} / \mathrm{Y}$ for Site U1376 igneous rocks. Black dots = lava flows, lobes, and clasts; blue dots = dikes. See Figure F10 for explanation of stratigraphy. Major element data are normalized to $100 \mathrm{wt} \%$ totals.

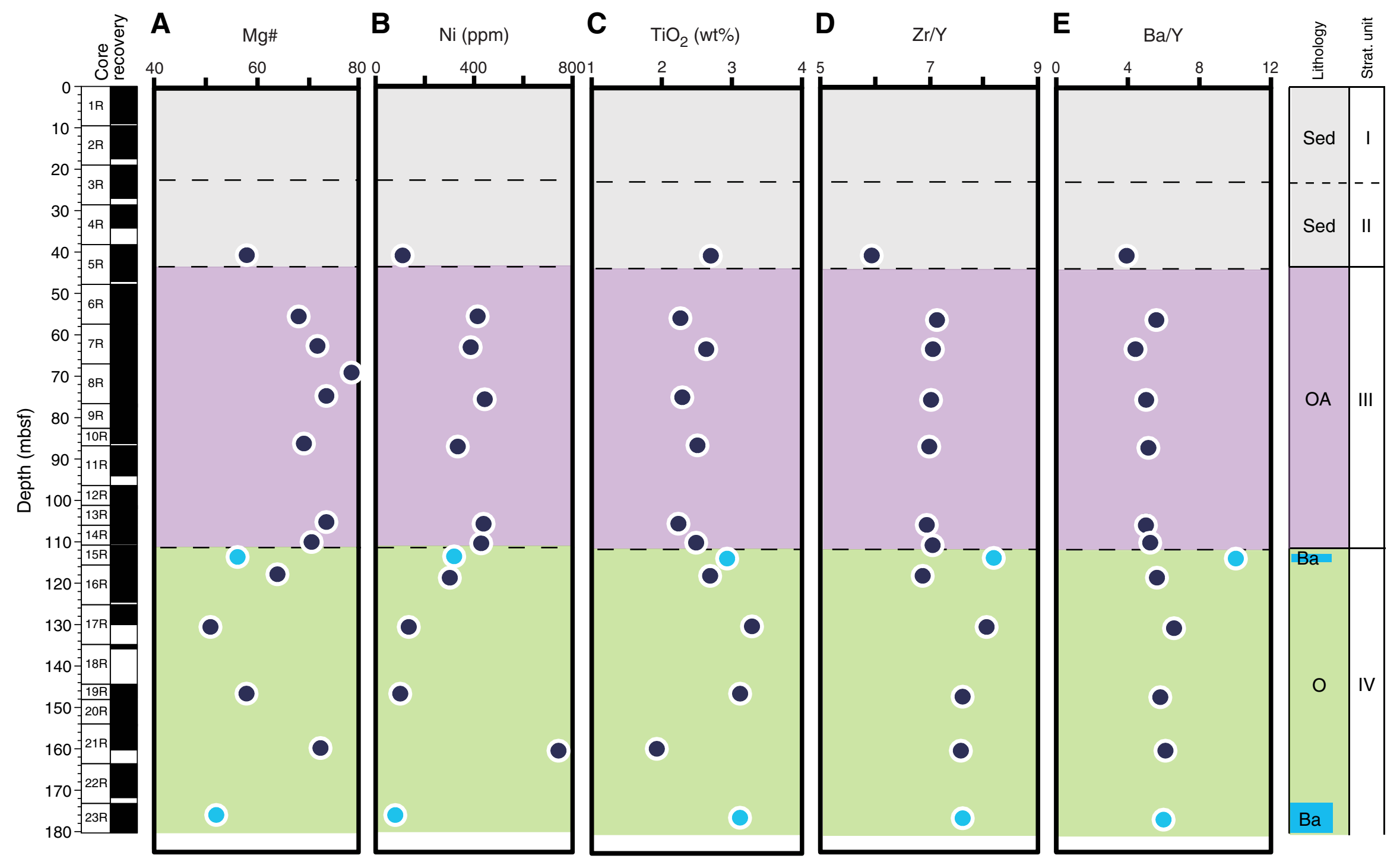


Figure F42. Depth profiles of magnetic susceptibility, Hole U1376A. Core recovery and stratigraphic columns are shown for reference. For explanation of stratigraphy, see Figure F10.

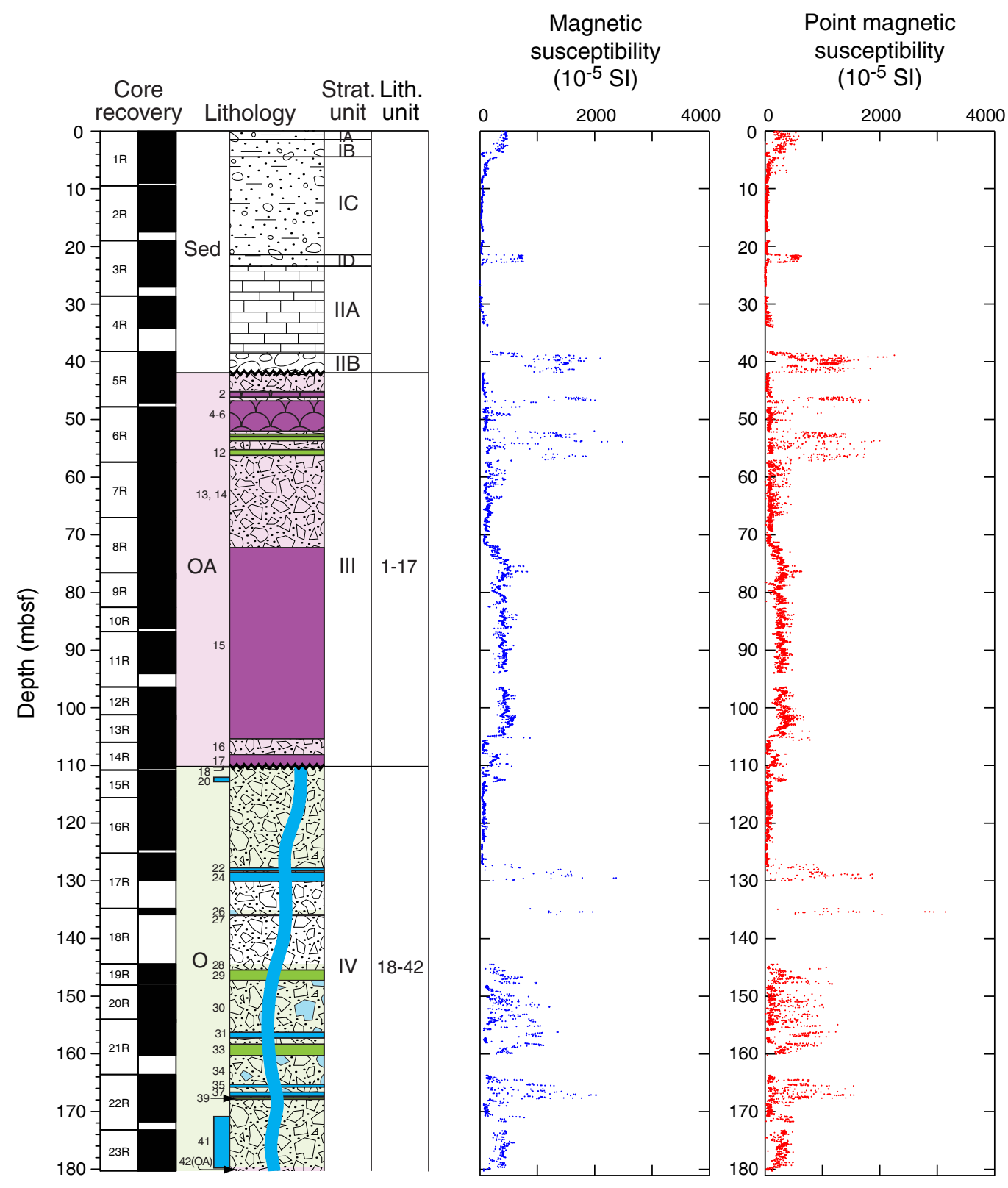


Figure F43. Depth profiles of bulk density and $P$-wave velocity for Hole U1376A, shown with corresponding stratigraphic column. Bulk density: red squares = MAD-C measurements taken on discrete samples, black dots $=$ GRA bulk density. $P$-wave velocity: blue $=x$-axis (normal to the split-core surface), red $=y$-axis (parallel to the split-core surface), green $=Z$-axis (downcore). For explanation of stratigraphy, see Figure F10.

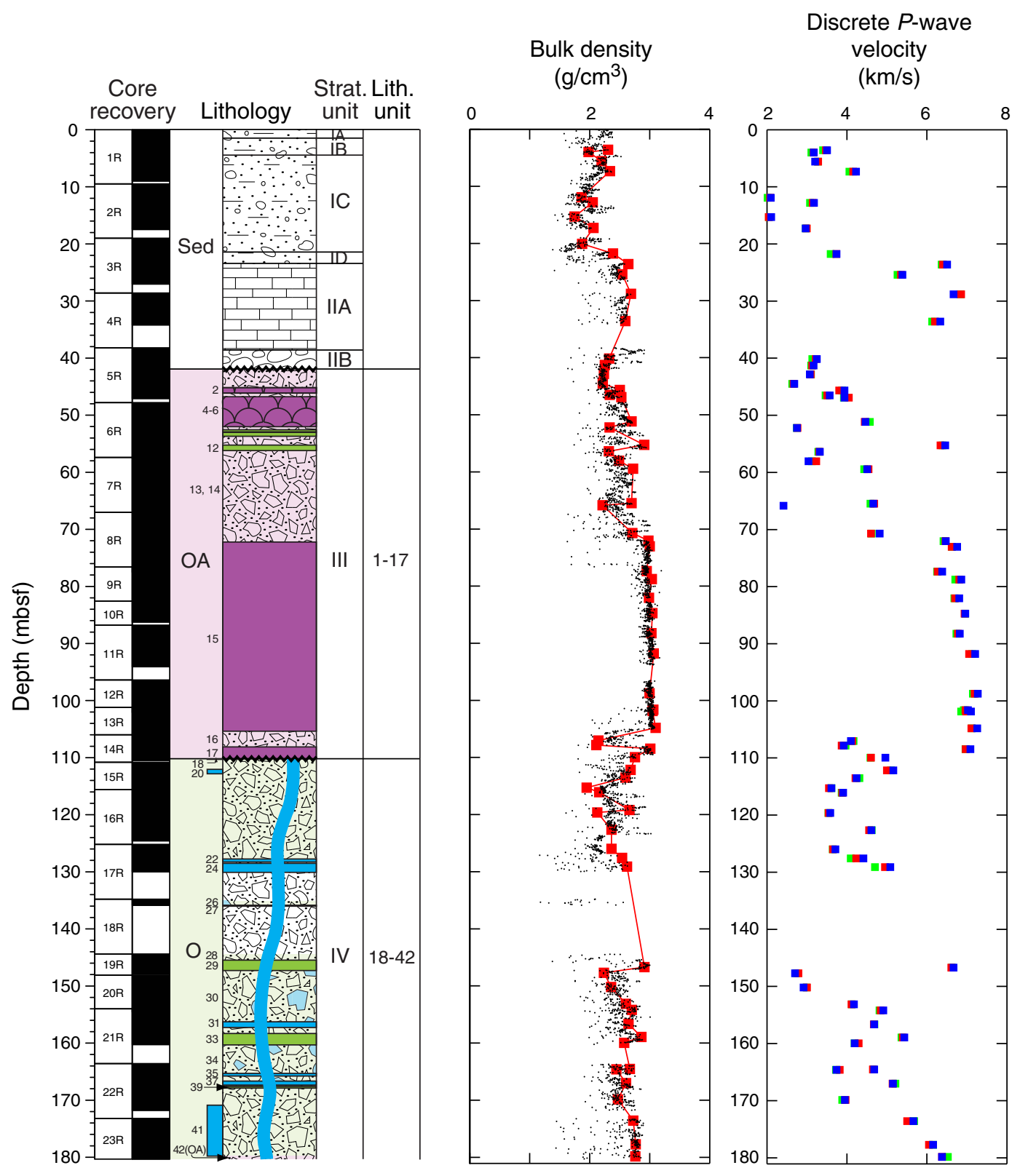


Figure F44. Depth profile of natural gamma radiation (NGR), Hole U1376A. Gray band delimits values between 9 and 14 cps. Stratigraphic column is shown for reference. For explanation of stratigraphy, see Figure F10.

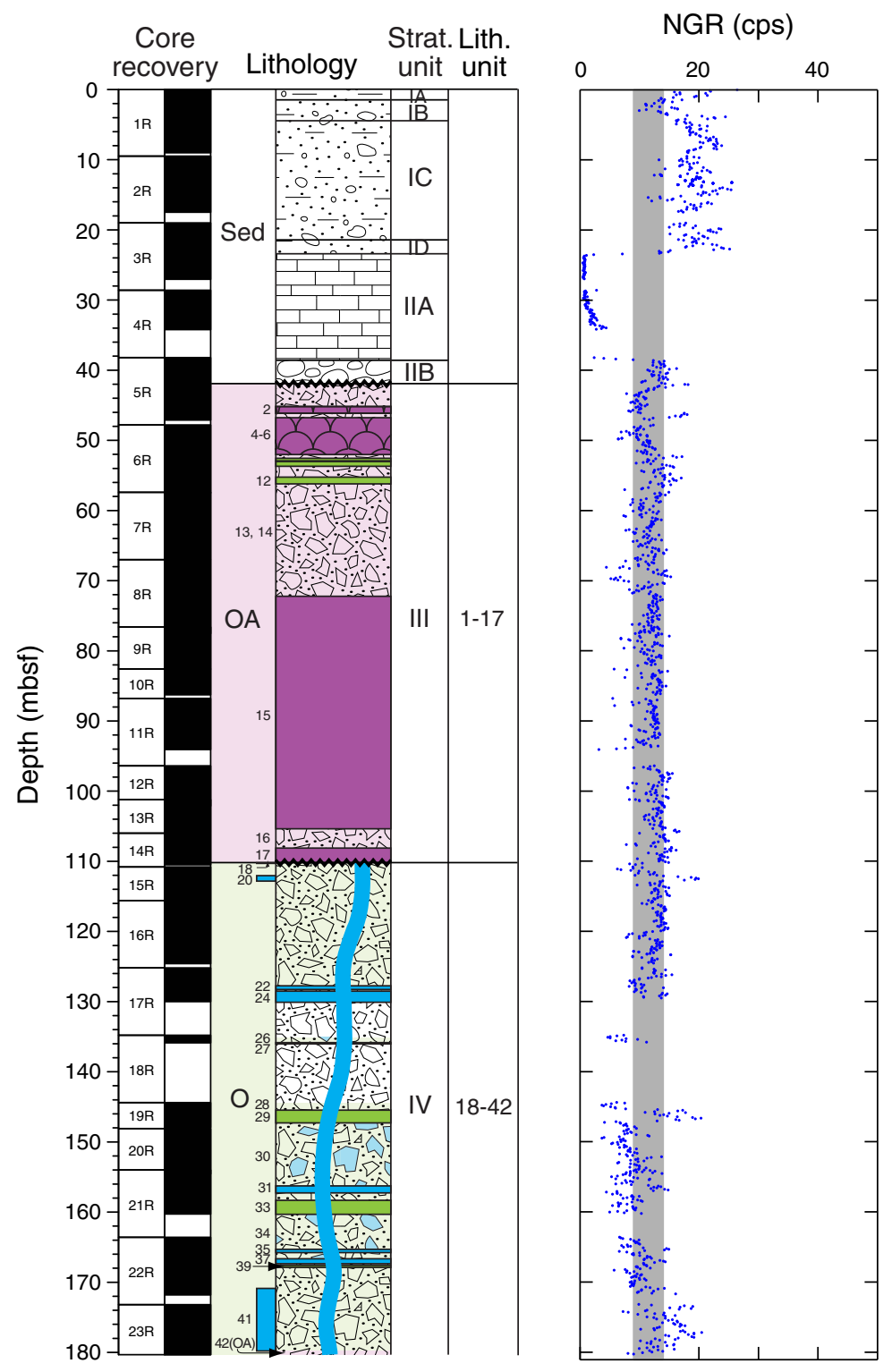


Figure F45. Depth profile of color reflectance parameters $L^{*}, a^{*}$, and $b^{*}$, Hole U1376A. Higher $L^{*}$ values indicate lighter colors. $\mathrm{a}^{*}=$ relative color position between red (positive) and green (negative), $\mathrm{b}^{*}=$ relative color position between yellow (positive) and blue (negative). Stratigraphic column is shown for reference. For explanation of stratigraphy, see Figure F10.

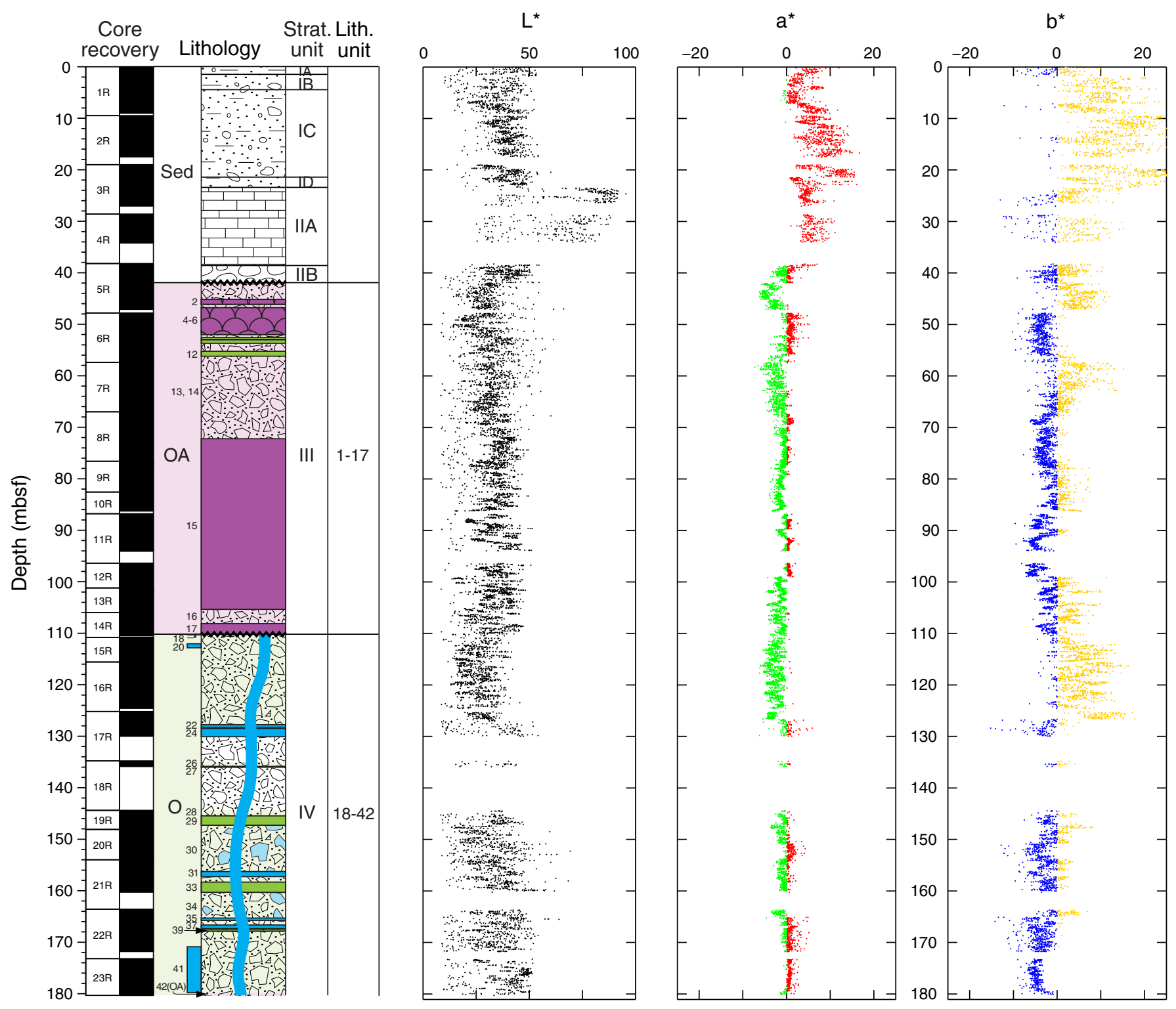


Figure F46. Plot of moisture and density Method C (MAD-C) bulk density vs. porosity of discrete samples, Hole U1376A. Results show an approximately linear negative correlation. Measurements on carbonate samples are shown as open circles and labeled " $\mathrm{C}$," and samples from the anomalous hyaloclastite interval in Cores 330U1376A-14R through 16R are labeled "A."

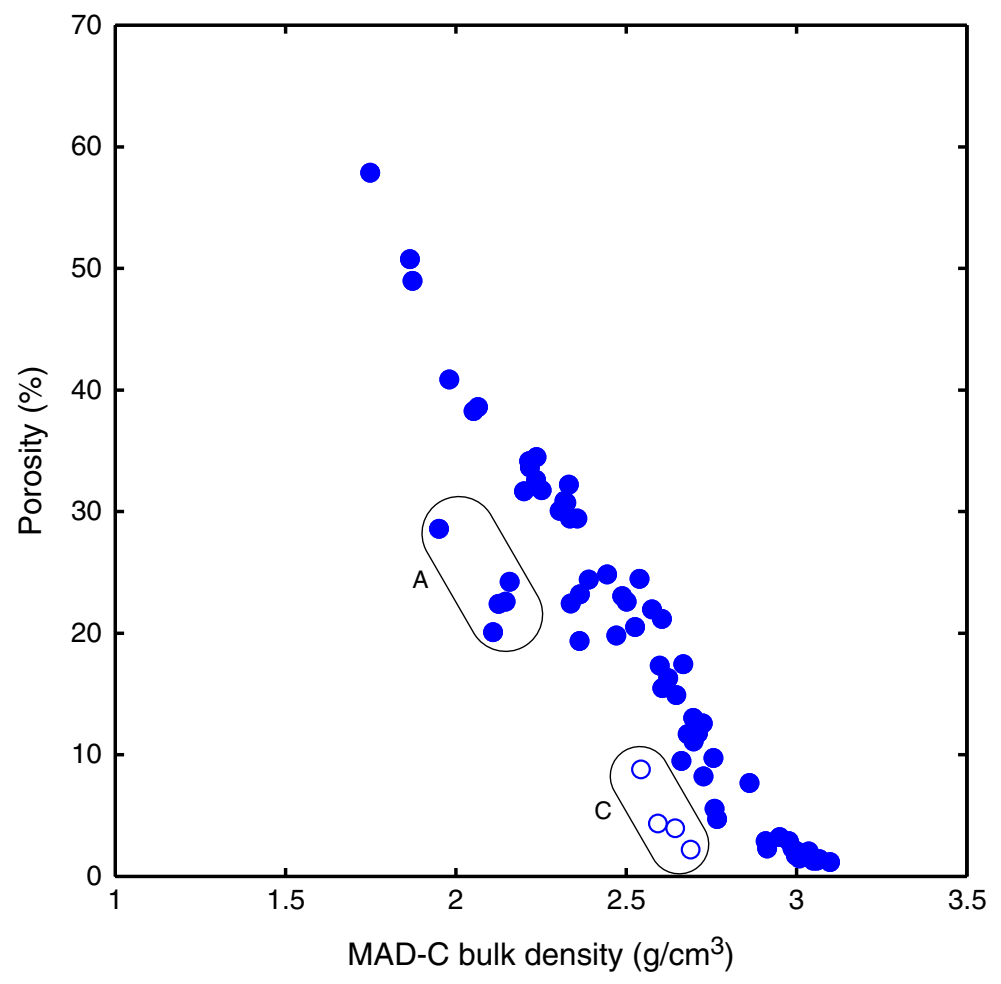


Figure F47. Plot of whole-round gamma ray attenuation (GRA) bulk density vs. moisture and density Method C (MAD-C) bulk density from discrete samples, Hole U1376A. Results show a nearly one-to-one linear relationship, with values from GRA bulk density often slightly lower than those from discrete samples. Data from cluster "B" were measured on samples from massive lava flows of lithologic Units 12, 15, 17, and 29. Samples from the anomalous hyaloclastite interval in Cores 330-U1376A-14R through 16R are labeled "A."

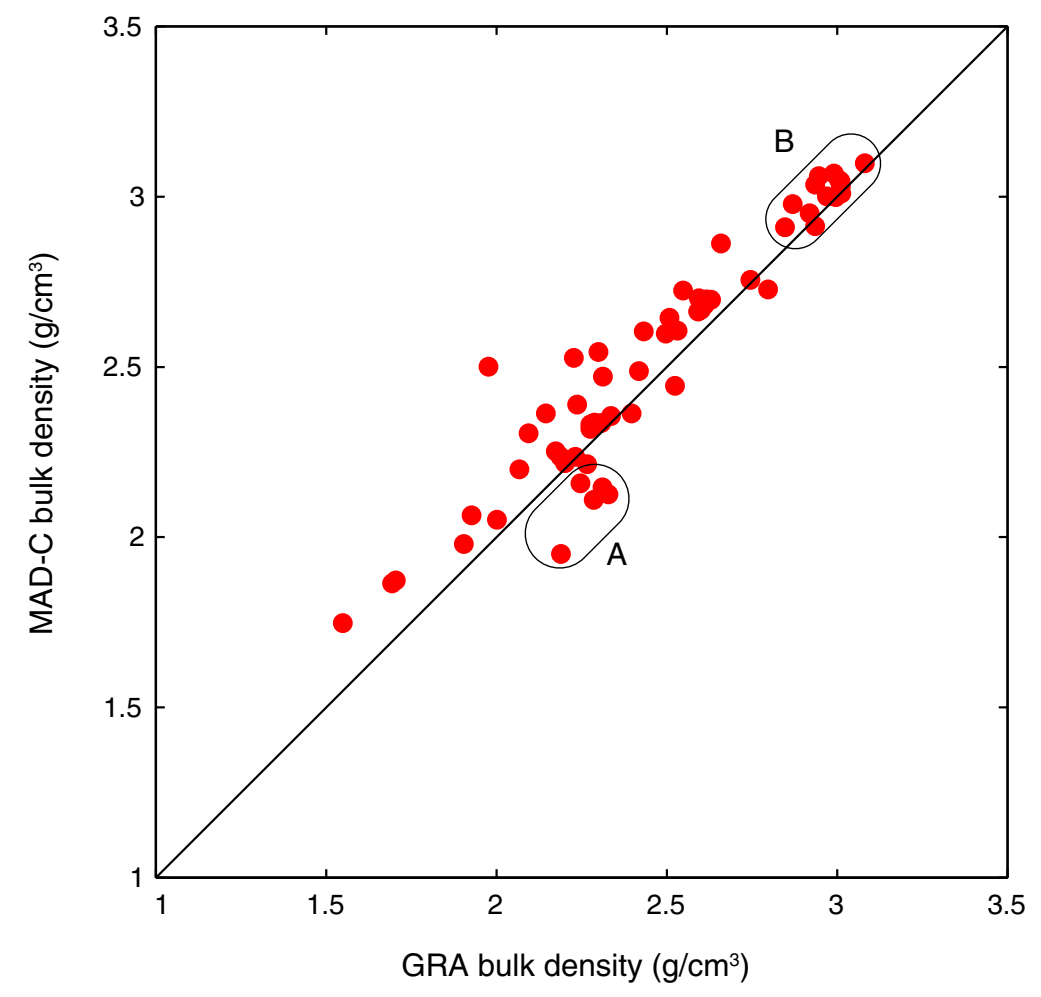


Figure F48. Depth profile of porosity from measurements on discrete samples, Hole U1376A, shown in relation to stratigraphic column. For explanation of stratigraphy, see Figure F10.

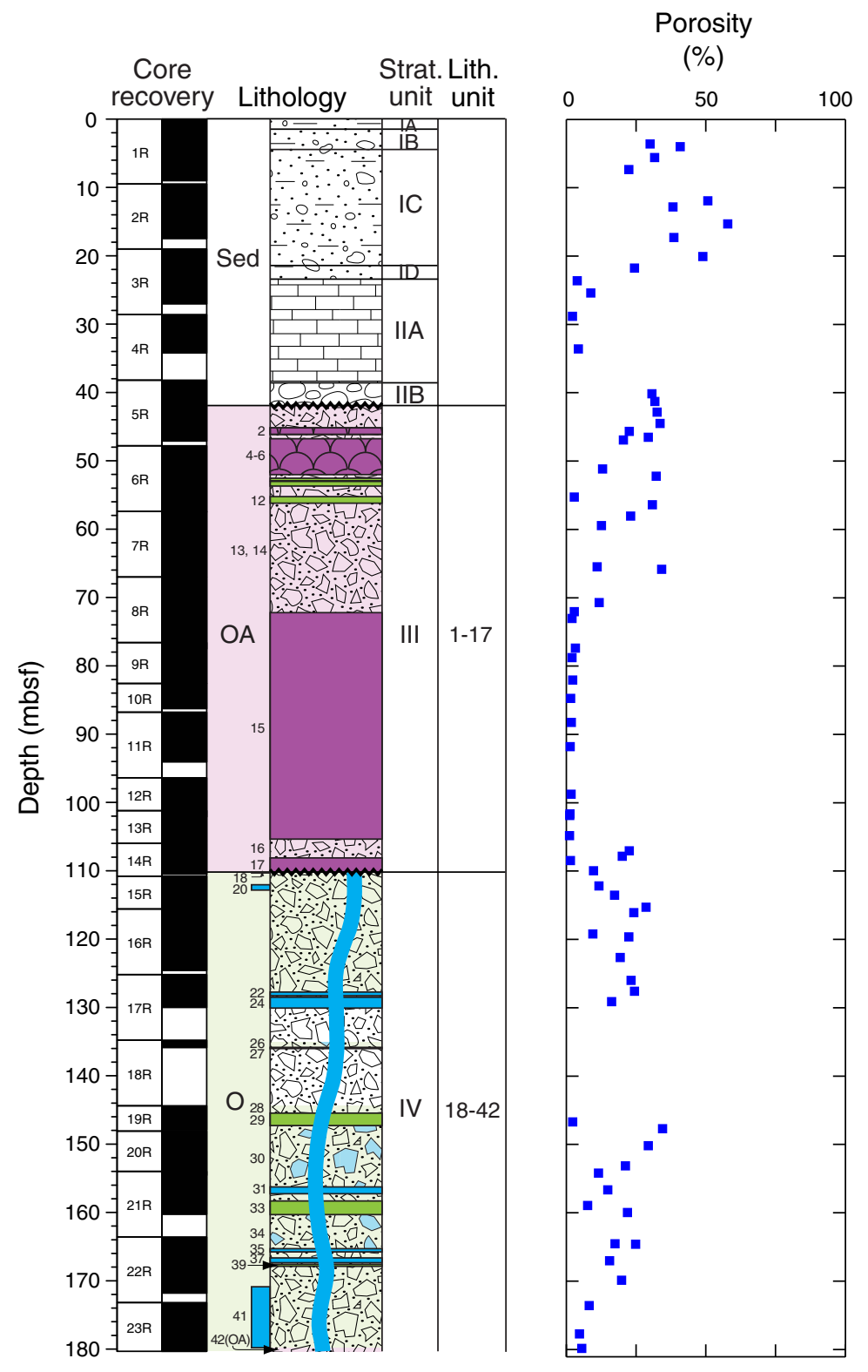


Figure F49. Plot of moisture and density Method C (MAD-C) bulk density values from discrete samples vs. discrete $P$-wave velocity, Hole U1376A, showing an approximately linear relationship. Colors represent different orientations for $P$-wave velocity measurements: blue $=x$-axis (normal to the split-core surface), red $=y$-axis (parallel to the split-core surface), green $=z$-axis (downcore). Measurements on carbonate samples are shown as open circles and labeled " $\mathrm{C}$ "; measurements in the massive lava flows of lithologic Units 12, 15, 17, and 29 are labeled "B"; and those in volcanic sandstone are labeled "S."

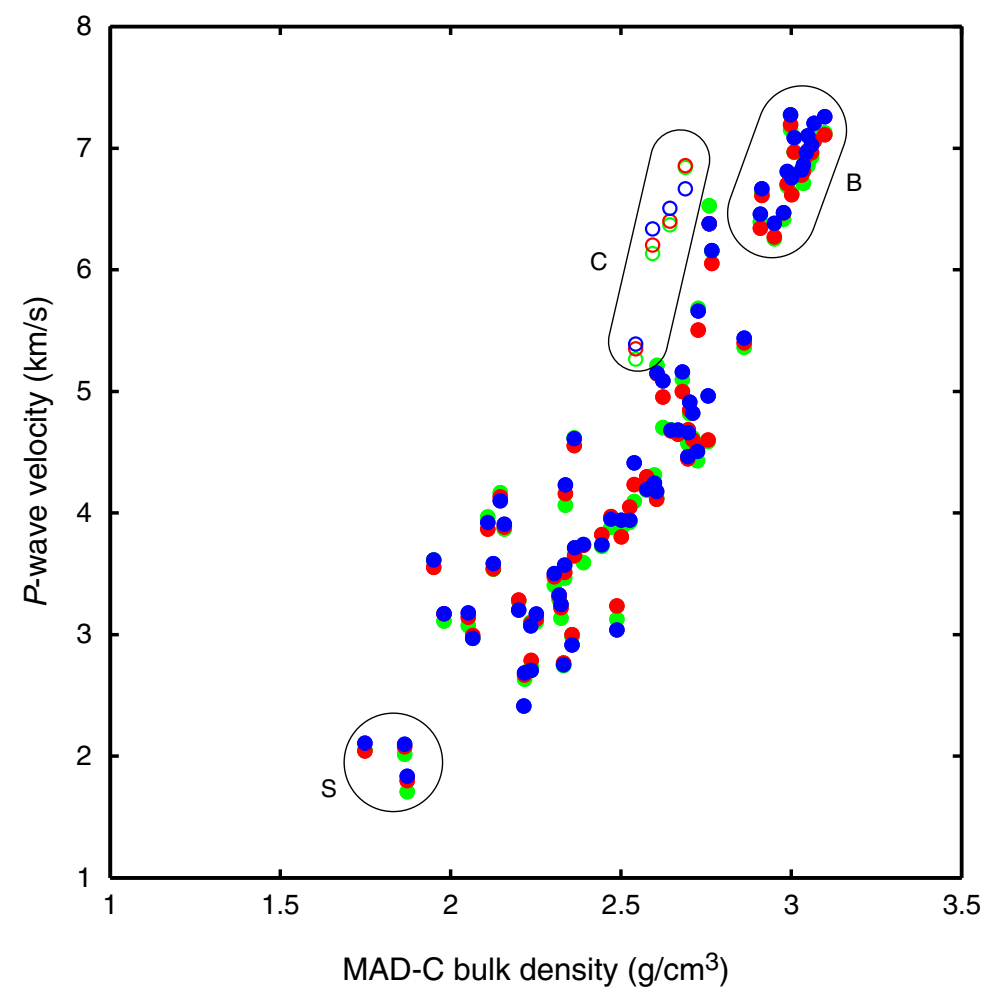


Figure F50. Downhole plots of paleomagnetic data from archive-half cores, Hole U1376A. A. Core recovery and observed stratigraphy (see Fig. F10 for explanation of patterns and abbreviations). B. Remanent intensity variations: purple $=$ NRM intensities, black $=$ intensities associated with principal component analysis (PCA) directions with misfits $\leq 2.56$, gray $=$ intensities associated with PCA directions with misfits $>2.56$. C. WRMSL magnetic susceptibility (see "Physical properties"). D. Inclination: red $=$ PCA directions with misfits $\leq 2.56$, pink $=$ PCA directions with misfits $>2.56$. E. Median destructive field of the vector difference sum $\left(\mathrm{MDF}^{\prime}\right)$, shown only for intervals with low misfit. (Figure shown on next page.) 
Figure F50 (continued). (Caption shown on previous page.)

A

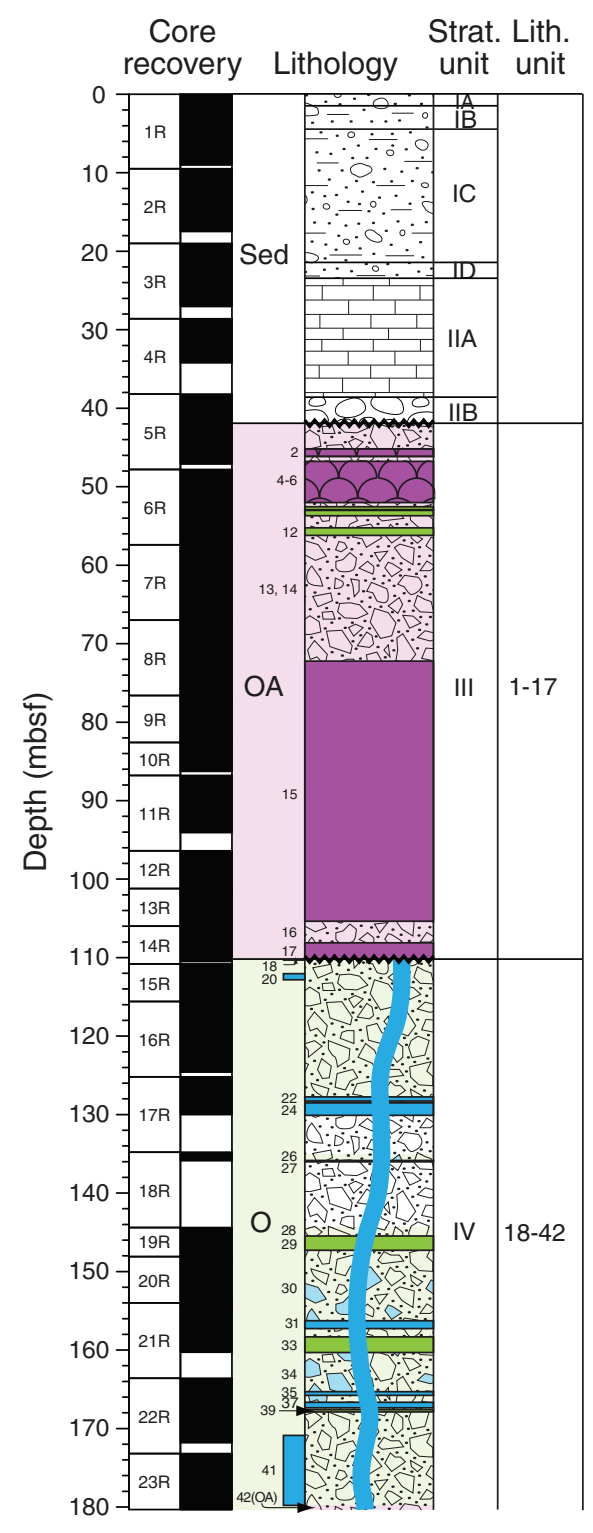

B

Log intensity
$(\mathrm{A} / \mathrm{m})$

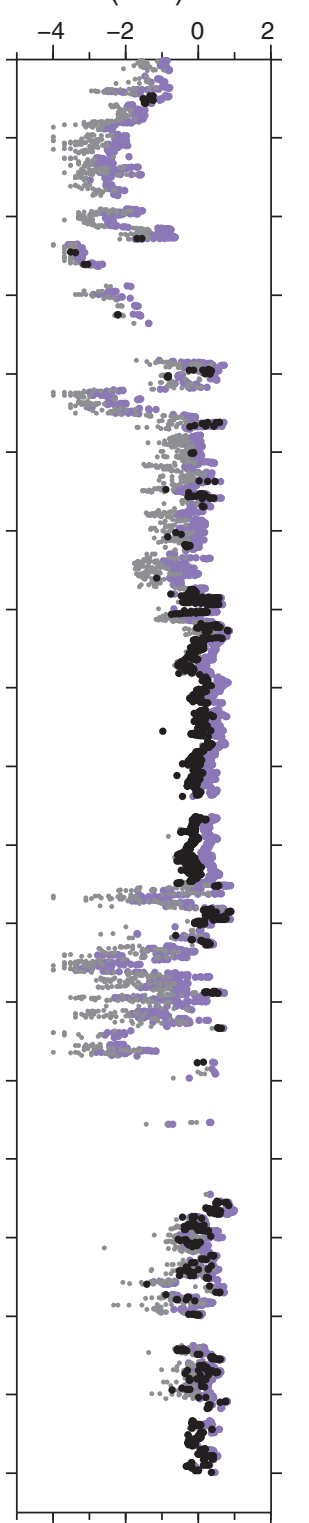

C Log susceptibility

$\left(10^{-5} \mathrm{SI}\right)$

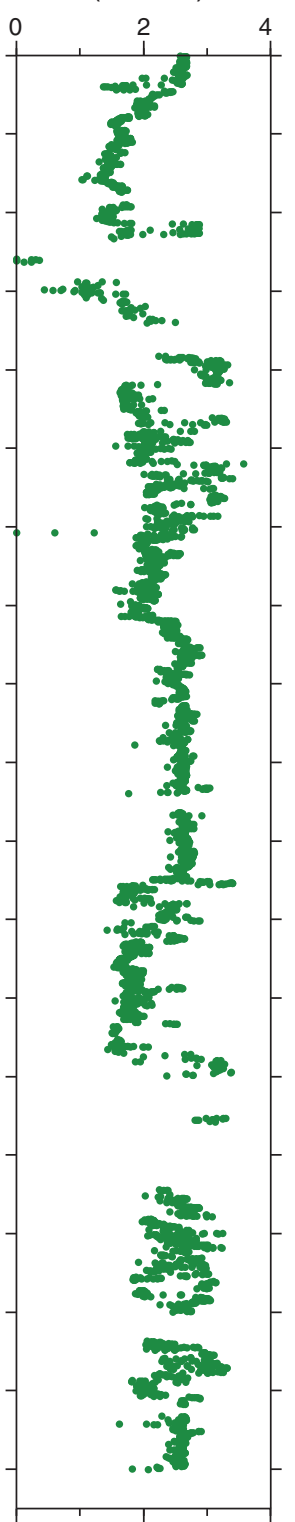

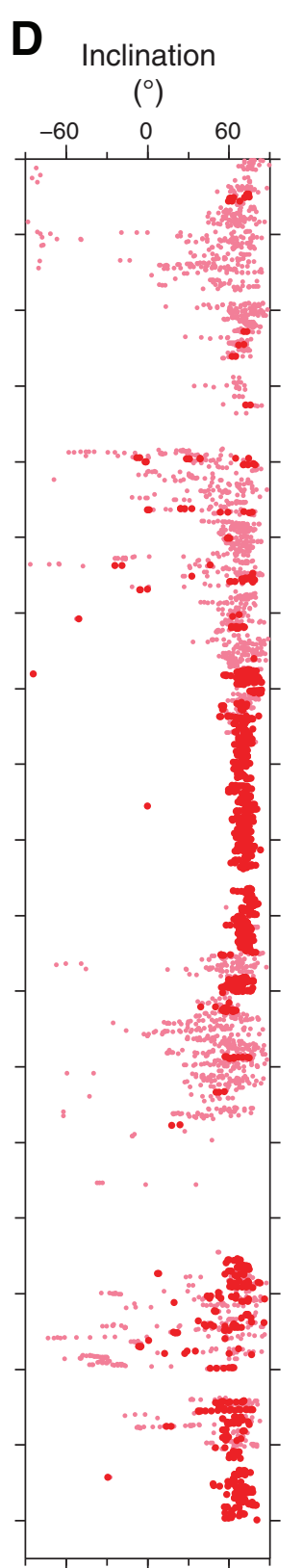

E

E MDF

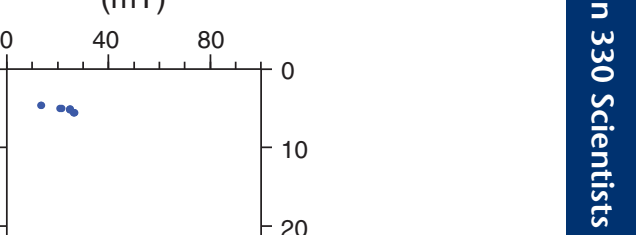


Figure F51. Log-log graph of natural remanent magnetization (NRM) intensity vs. Königsberger ratio (Qn) for discrete samples from different lithologies, Hole U1376A. Two limestone samples have negative susceptibilities (i.e., diamagnetic), and for these we used the absolute values in the calculation of $Q n$ values.

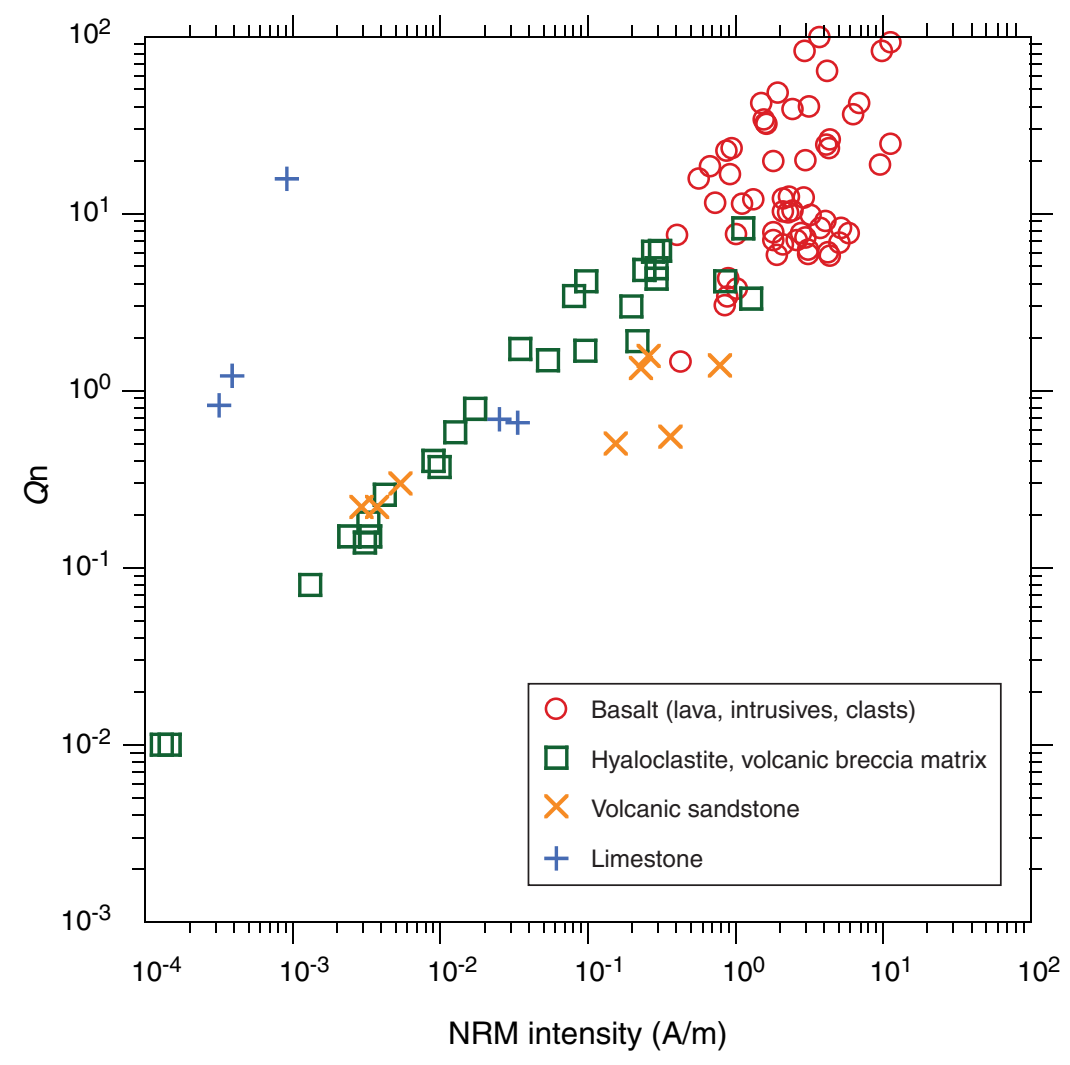




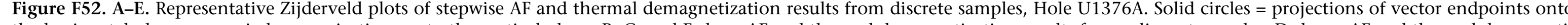

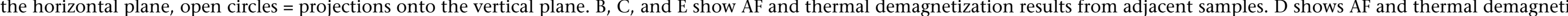

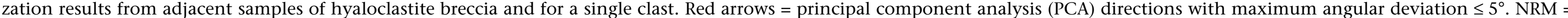
natural remanent magnetization.

A

330-U1376A-1R-3, $87-89 \mathrm{~cm}$

330-U1376A-3R-4, 104-106 cm

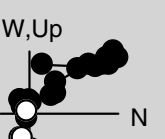

$600^{\circ} \mathrm{C}$

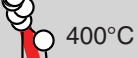

$10400^{\circ} \mathrm{C}$

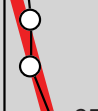

$250^{\circ} \mathrm{C}$



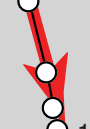

$Q$

D

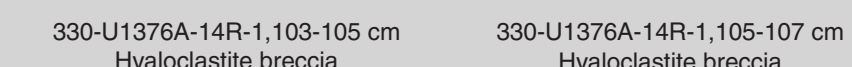

Hyaloclastite breccia
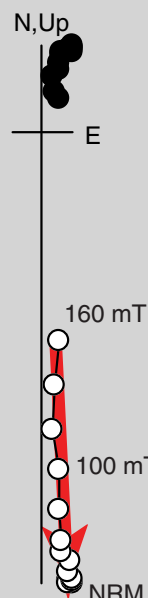

B

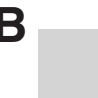

330-U1376A-5R-6, 77-79 cm

N,Up

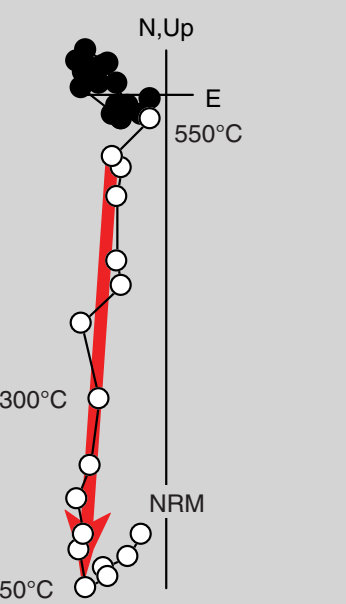

330-U1376A-14R-1, 105-107 cm Hyaloclastite breccia

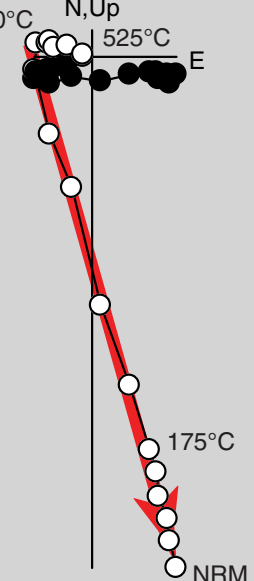

330-U1376A-16R-3, 134-136 cm (last in hyaloch

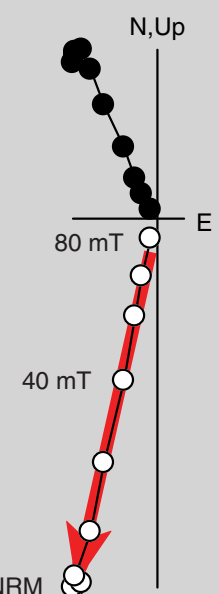

330-U1375-5. Vesicuat- pR-6, 82-84 cm N,Up

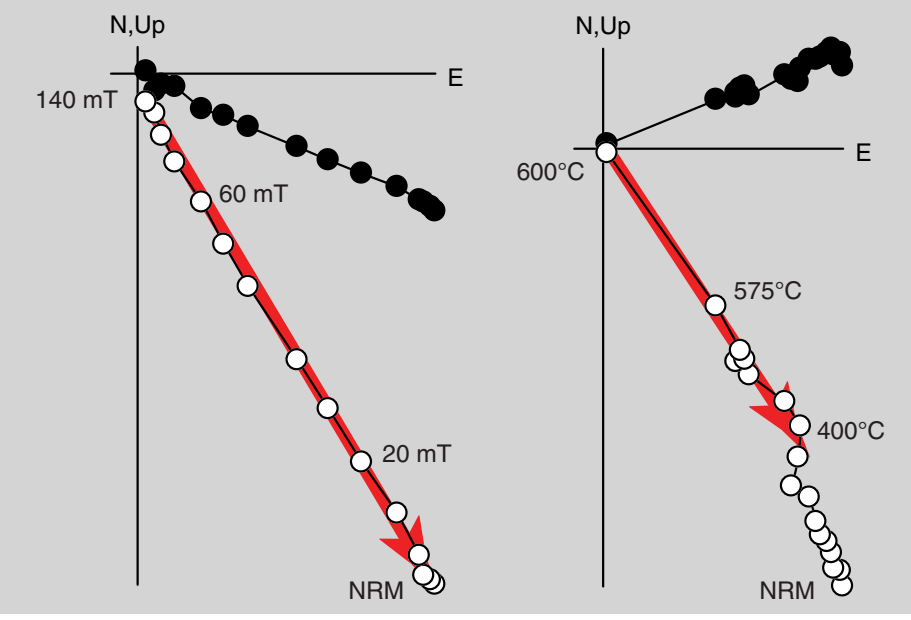

330-U1376A-16R-3, 139-141 cm Clast in hyaloclastite brecci

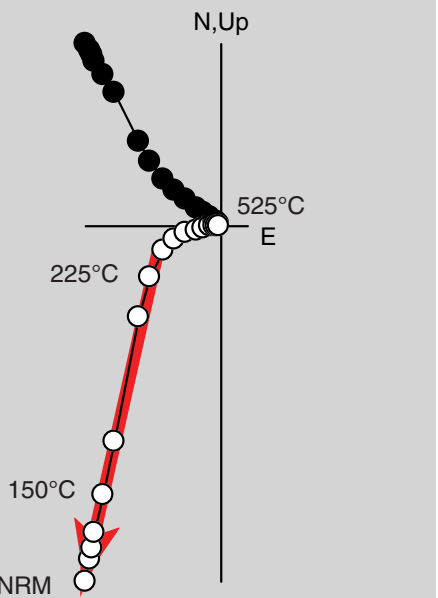

E

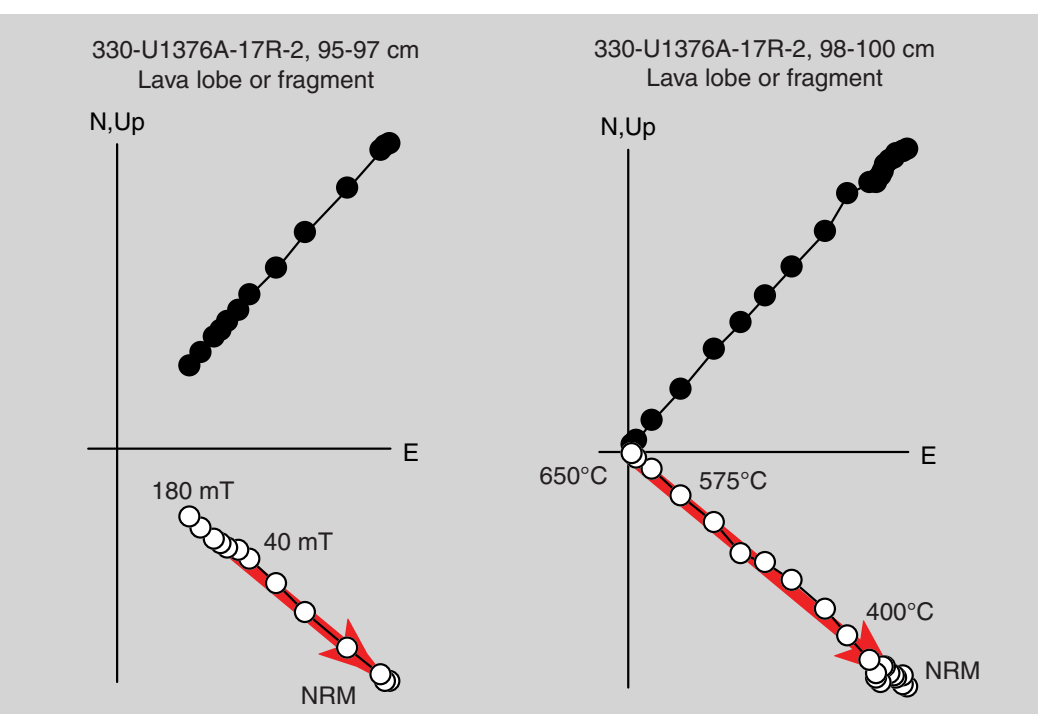

C

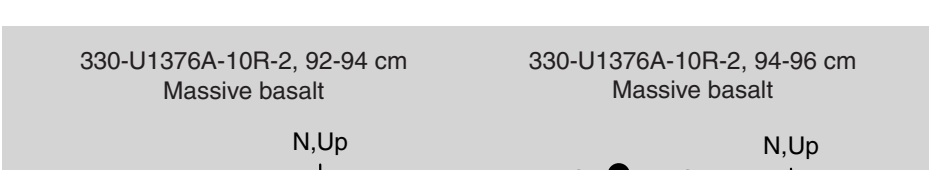

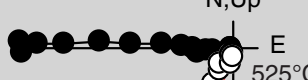
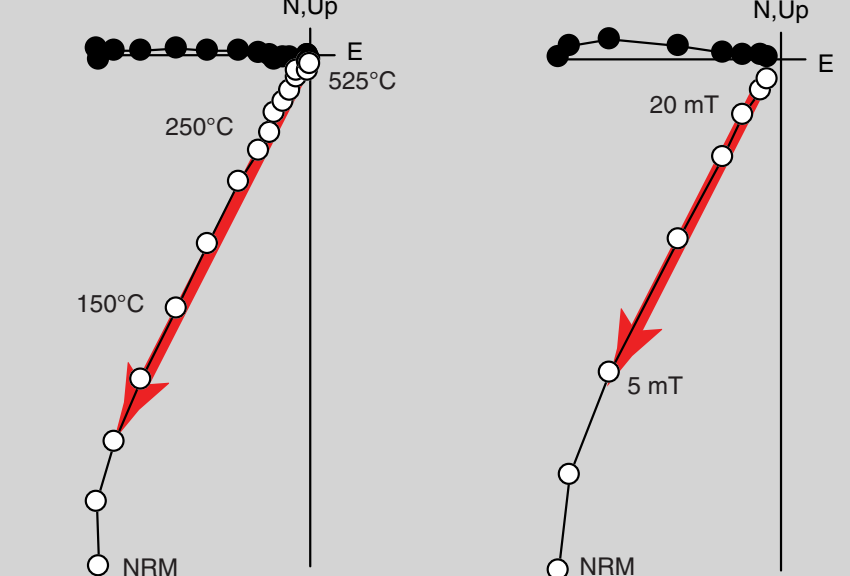

ONRM

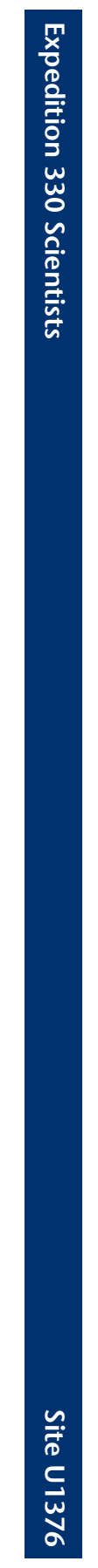


Figure F53. Downhole plots of inclination, Hole U1376A. A. Core recovery and observed stratigraphy (see Fig. F10 for explanation of patterns and abbreviations). B. All downhole inclination data measured at $2 \mathrm{~cm}$ intervals on archive-half cores: red = principal component analysis (PCA) directions with misfits $\leq 2.56$, pink $=$ PCA directions with misfits $>2.56$. C. Average inclination for each lithologic unit (see "Igneous petrology and volcanology"), calculated using inclination-only statistics. D. Average inclination for each core piece longer than $9 \mathrm{~cm}$, calculated using Fisher statistics. E. Average inclination for each lithologic unit, calculated using average piece directions displayed in $\mathrm{D}$ and inclination-only statistics. F. Characteristic remanent magnetization inclinations from discrete samples (from alternating-field $[\mathrm{AF}]$ or thermal demagnetization) with maximum angular deviation $\leq 5^{\circ}$. Shading scheme for C-F represents the ISCI for identifying distinct lava flow units, where the darkest shade of blue is the most confident and green is not applicable (NA; i.e., deposits cannot have retained their orientation since cooling). (Figure shown on next page.) 
Figure F53 (continued). (Caption shown on previous page.)

A

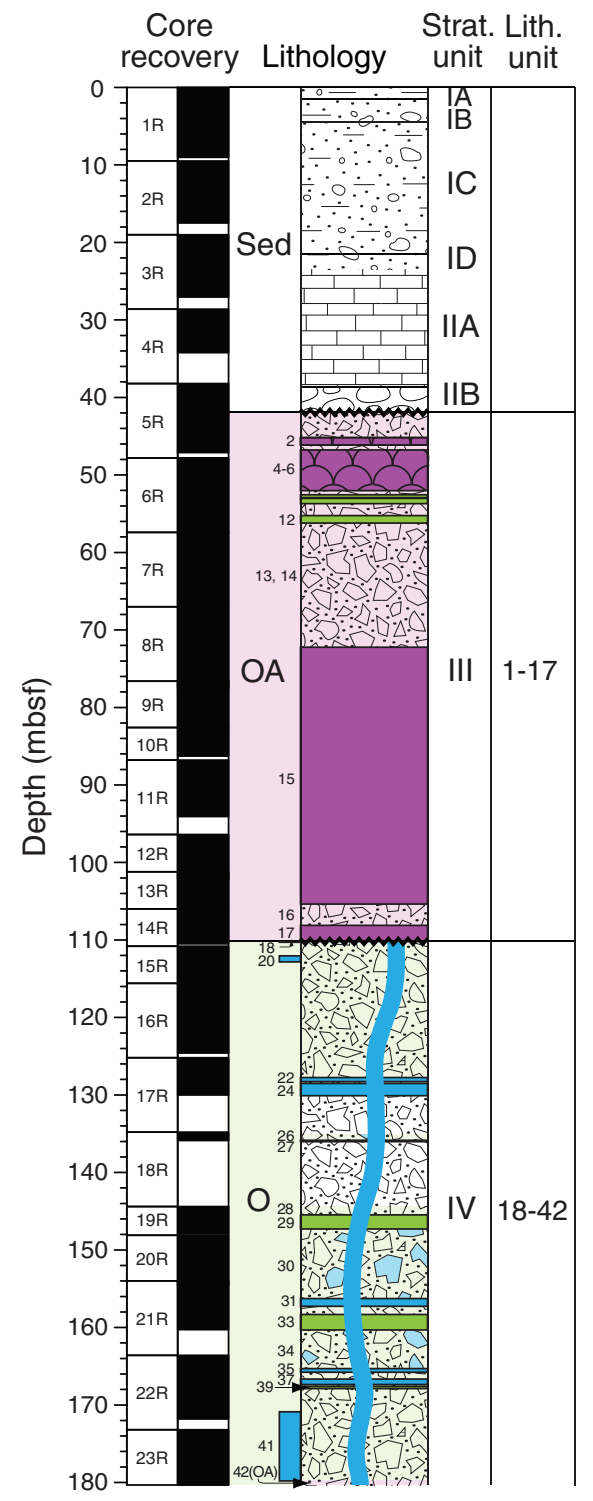

B Archive-half
inclination $\left({ }^{\circ}\right)$

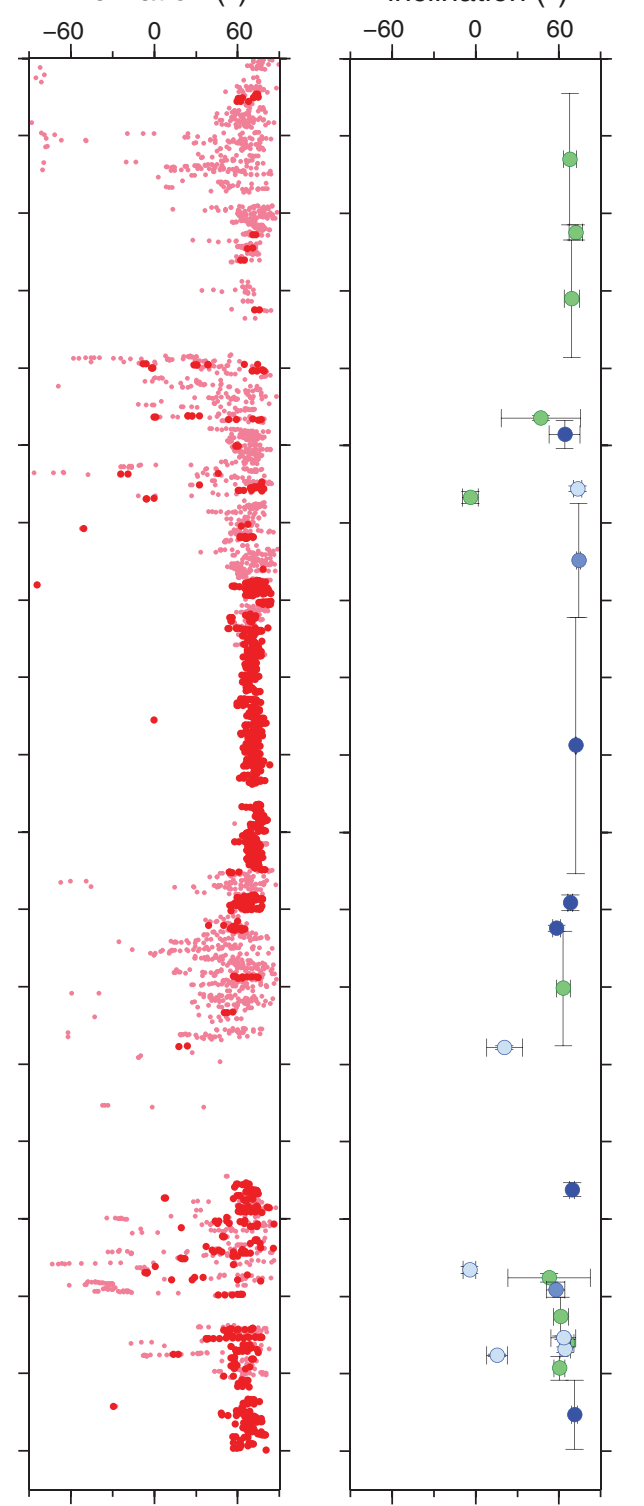

In situ confidence index (ISCI):

c

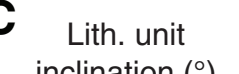

D

Piece

inclination $\left(^{\circ}\right)$

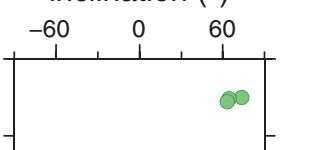

$E_{\text {Lith. }}$ inclination ( $\left(^{\circ}\right)$

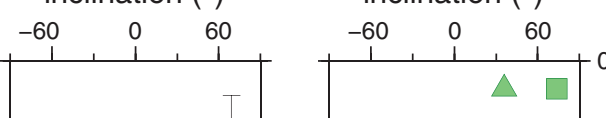

$-10$ $-20$

$-30$

$\Delta-40$

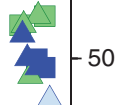

$-60$

$-70$

$\underbrace{-70}_{-80}$

贵 -90

A -100

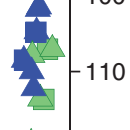

$\Delta-120$

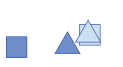

$-130$

$-140$

-

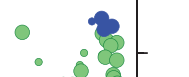

○ं०

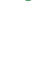

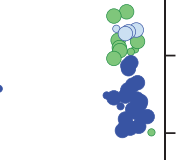

(3)

Lava flow (2)

$\bigcirc$ Lava flow (1) $\bigcirc$ Lava flow (0) 
Figure F54. Plots of magnetic parameters recorded over 65-110 mbsf (lithologic Units 14-17), Hole U1376A. A. WRMSL magnetic susceptibility (green) and point magnetic susceptibility (light green) (see "Physical properties"). B. Median destructive field of the vector difference sum (MDF'). C. Remanent magnetization intensity: black $=$ principal component analysis $($ PCA) directions with misfit $\leq 2.56$, gray $=$ PCA directions with misfit $>$ 2.56. D. Log intensity: purple $=$ NRM intensity, black/gray $=$ same as in C. E. Inclination from archive-half core data measured at $2 \mathrm{~cm}$ intervals: red $=$ PCA directions with misfit $\leq 2.56$, pink $=$ PCA directions with misfit $>$ 2.56, blue $=$ inclination-only average for lithologic Units 15 and 17 (inclination error is the $\alpha_{95}$ cone of confidence, but is generally smaller than the symbol size). F. Fisher piece-average inclinations from archive-half core data. Dark and light blue symbols represent lithologic units with an in situ confidence index (ISCI) of 3 and 2, respectively. Red = inclination-only average of Fisher piece averages in lithologic Units 15 and 17 (inclination error is the $\alpha_{95}$ cone of confidence but is generally smaller than the symbol size). NA = not applicable. (Figure shown on next page.) 
Figure F54 (continued). (Caption shown on previous page.)

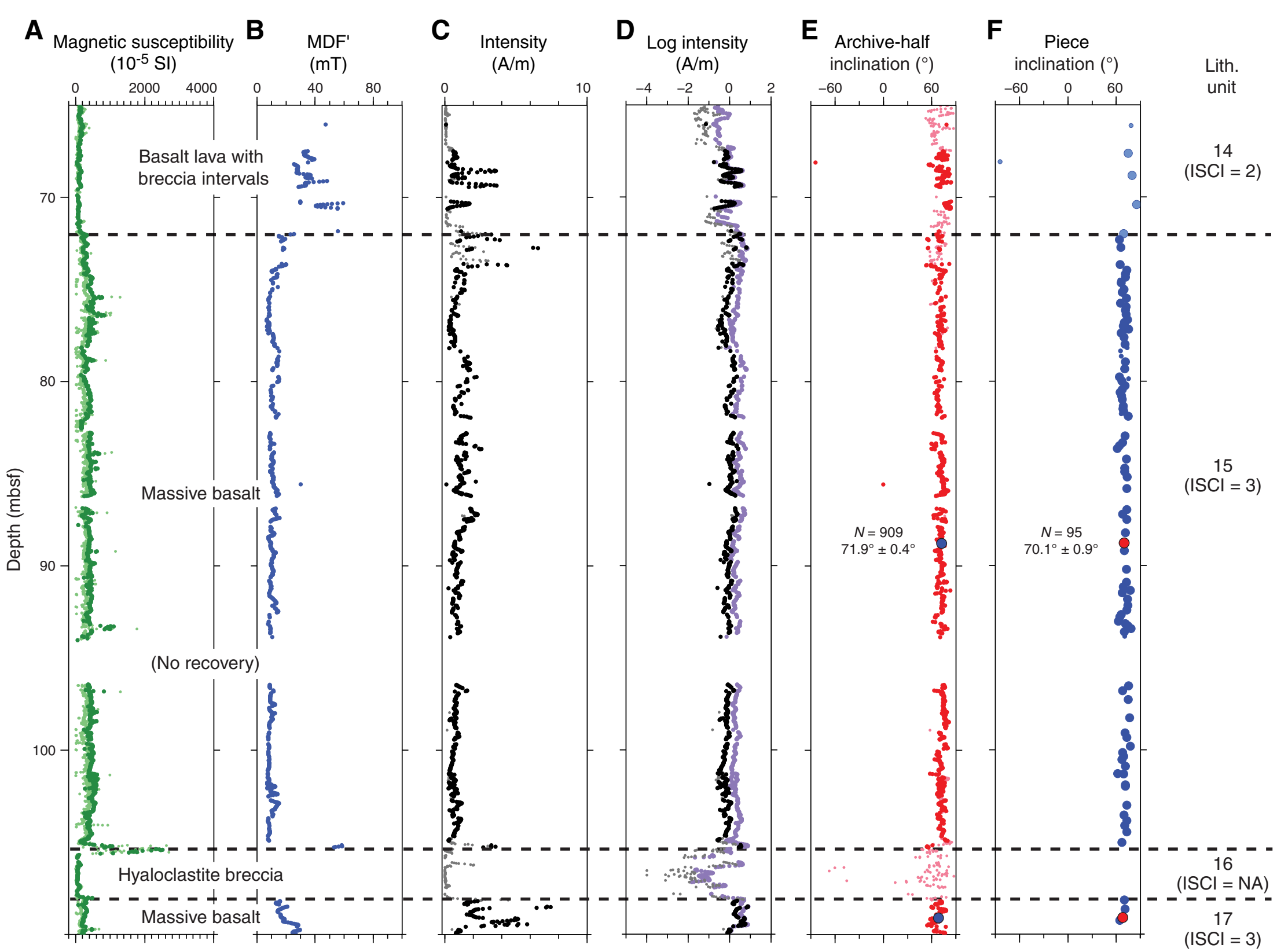


Figure F55. Plots of paleomagnetic data for upper and lower boundaries of lithologic Unit 15, Sections 330U1376A-8R-4 and 13R-4. A, C. Inclination (solid red symbols = principal component analysis [PCA] inclination with misfit $\leq 2.56$, solid pink symbols $=$ PCA inclination with misfits $>2.56$, open red symbols $=$ Fisher pieceaverage inclinations); intensity (solid black symbols $=$ PCA intensity with misfit $\leq 2.56$, gray symbols $=$ data with misfits > 2.56); median destructive field of the vector difference sum (MDF'; blue symbols); WRMSL magnetic susceptibility (dark green symbols) and point magnetic susceptibility (light green symbols) (see "Physical properties"). B, D, E. Zijderveld diagrams (sample locations shown by gray arrows in A and C). Solid symbols $=$ projections of vector endpoints onto horizontal plane, open symbols $=$ projections of vector endpoints onto vertical plane. $\mathrm{ISCI}=$ in situ confidence index, NA = not applicable.

A

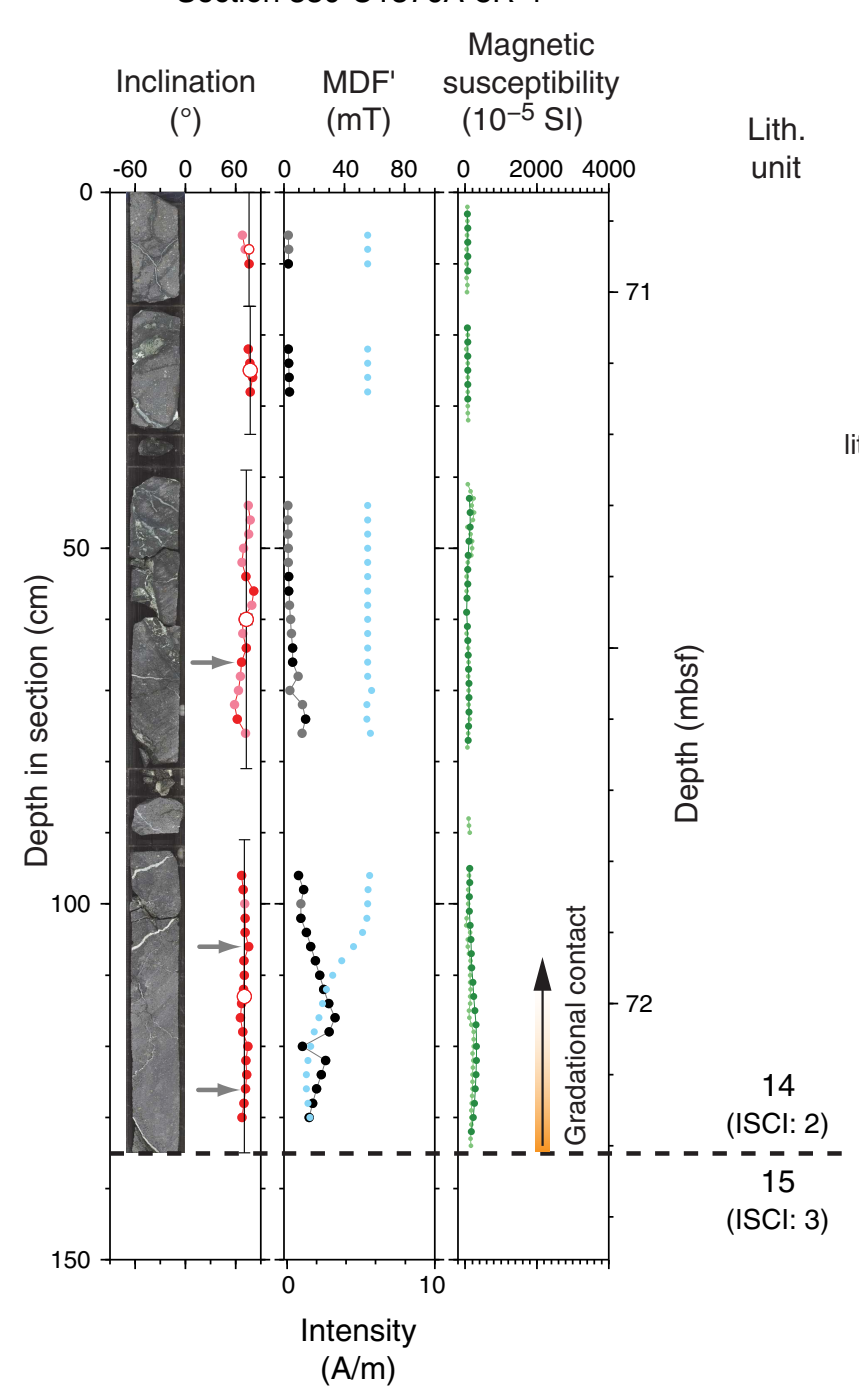

B

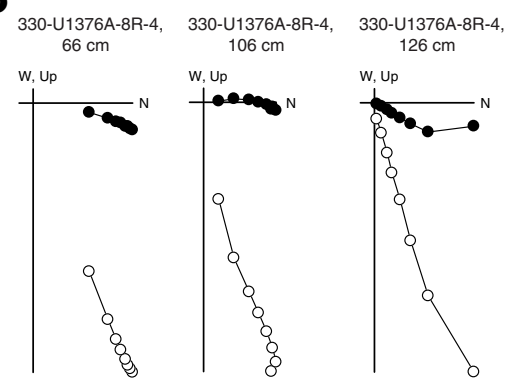

Lith. Unit 14 (ISCI: 2)

D
C

Section 330-U1376A-13R-4

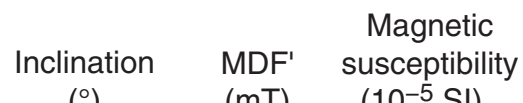

$\left({ }^{\circ}\right) \quad(\mathrm{mT}) \quad\left(10^{-5} \mathrm{SI}\right)$

Lith.

unit
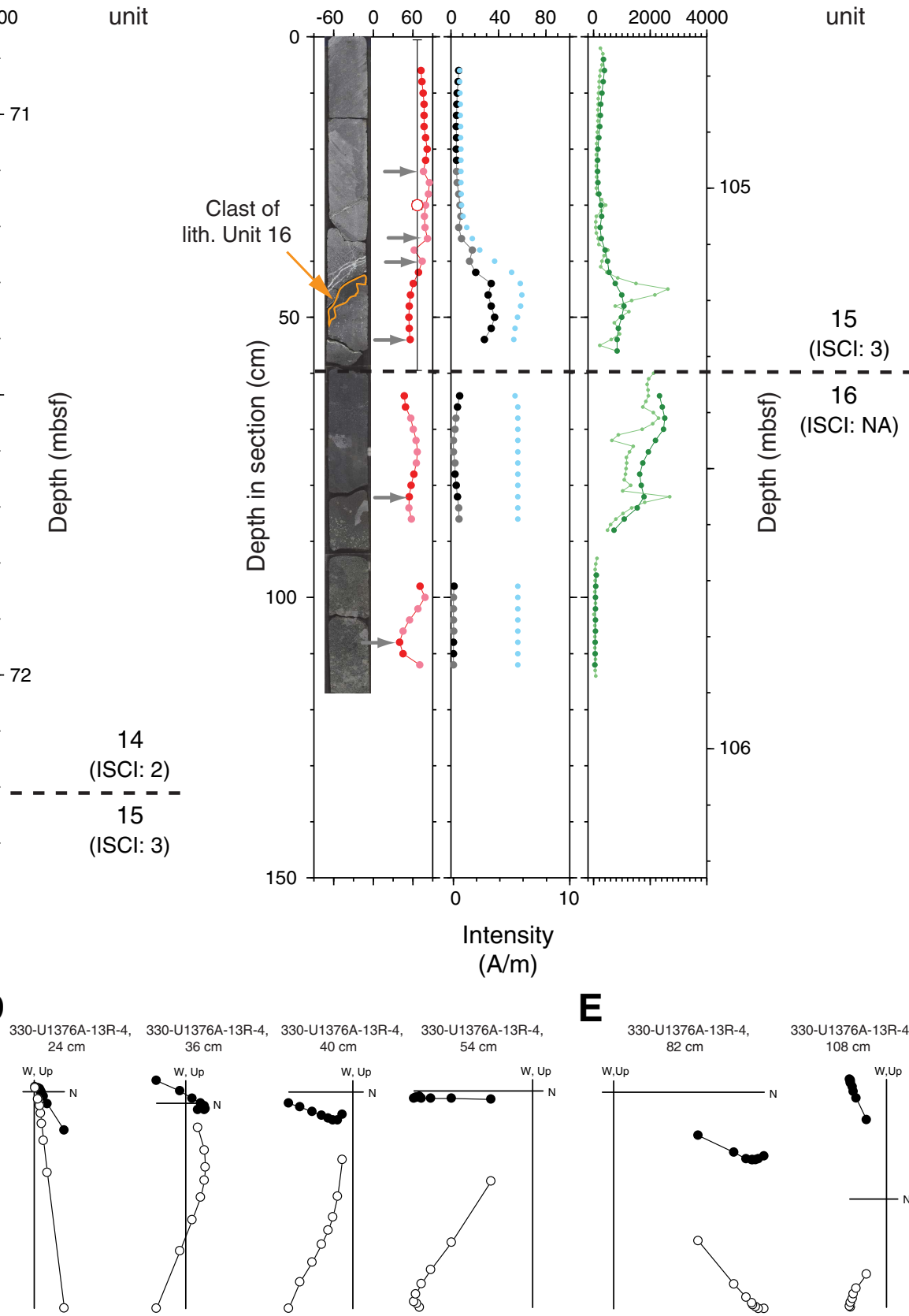

Lith. Unit 15 (ISCI: 3)
E

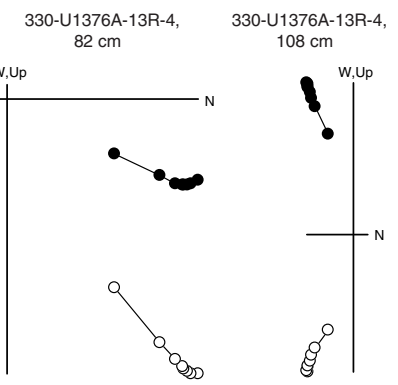

Lith. Unit 16 (ISCI: NA) 
Figure F56. Histograms of Hole U1376A inclination. A. All archive-half core data measured at $2 \mathrm{~cm}$ intervals. B. All archive-half core data measured at $2 \mathrm{~cm}$ intervals with misfit $\leq 2.56$. C. All archive-half core data measured at $2 \mathrm{~cm}$ intervals with misfit $\leq 2.56$ and from lithologic units with ISCI of 3 or 2 . D. Fisher piece-average archive-half core data with CSD $\leq 20^{\circ}$ and from lithologic units with ISCI of 3 or 2. E. Discrete samples from lithologic units with ISCI of 3 or 2 . Note that because of the uncertainty in whether some individual units are in situ, averages by lithologic unit have not been calculated. Statistics presented are inclination-only means $\left(\alpha_{95}\right){ }^{*}=$ mean calculated without negative inclination samples.
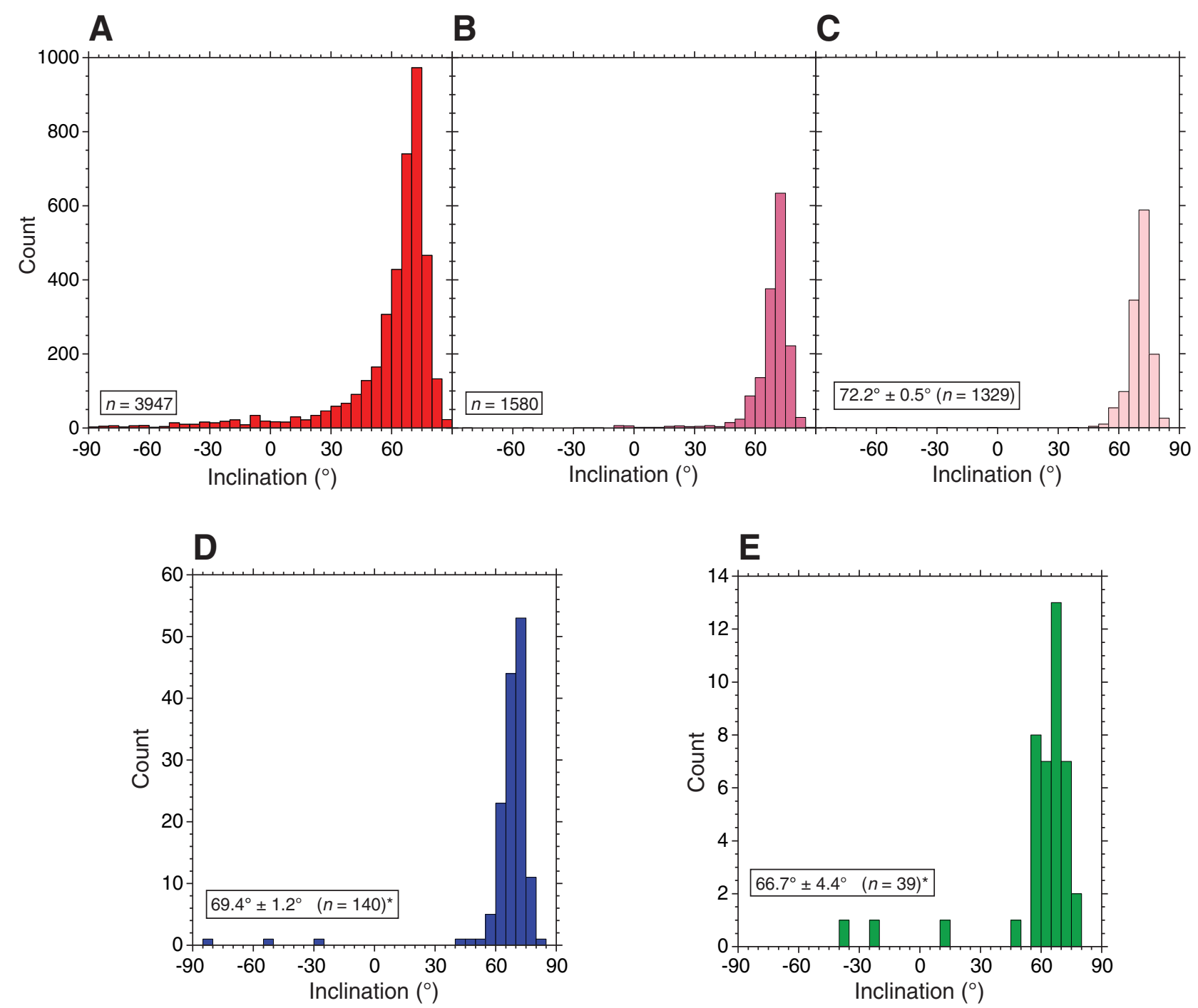
Figure F57. A. Triple combination tool string. HNGS = Hostile Environment Natural Gamma Ray Sonde, APS = Accelerator Porosity Sonde, HLDS = Hostile Environment Litho-Density Sonde, GPIT = General Purpose Inclinometry Tool, DIT = Dual Induction Tool. B. Schematic of Hole U1376A logging passes (one downlog, a main uplog, and a full uplog repeat pass).

A

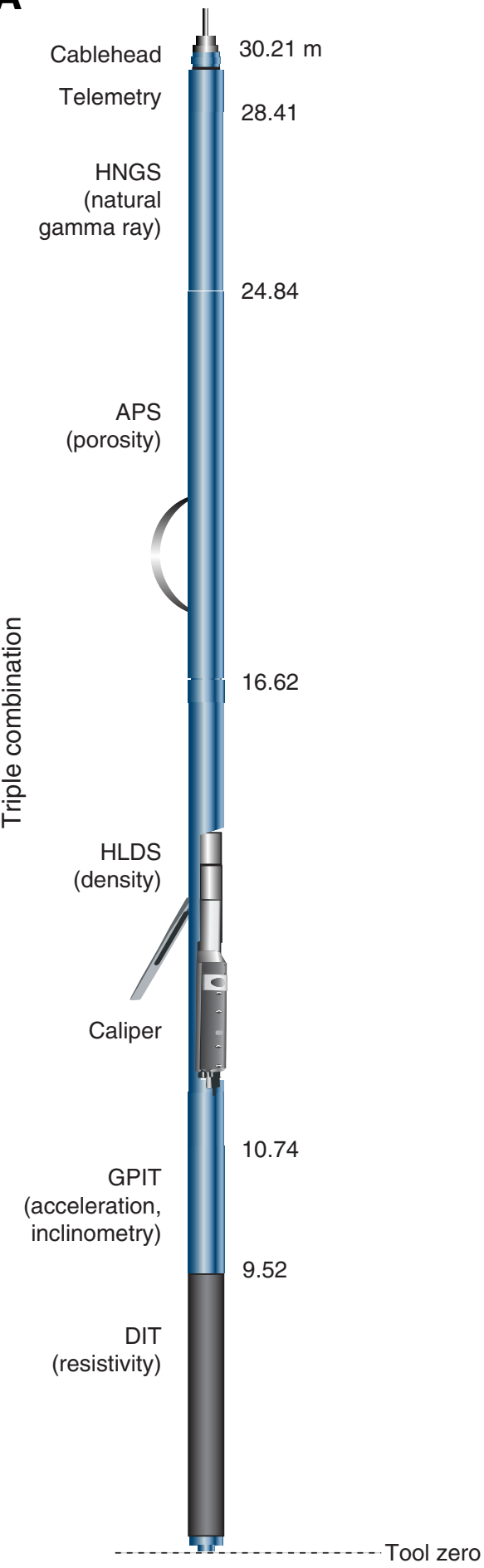

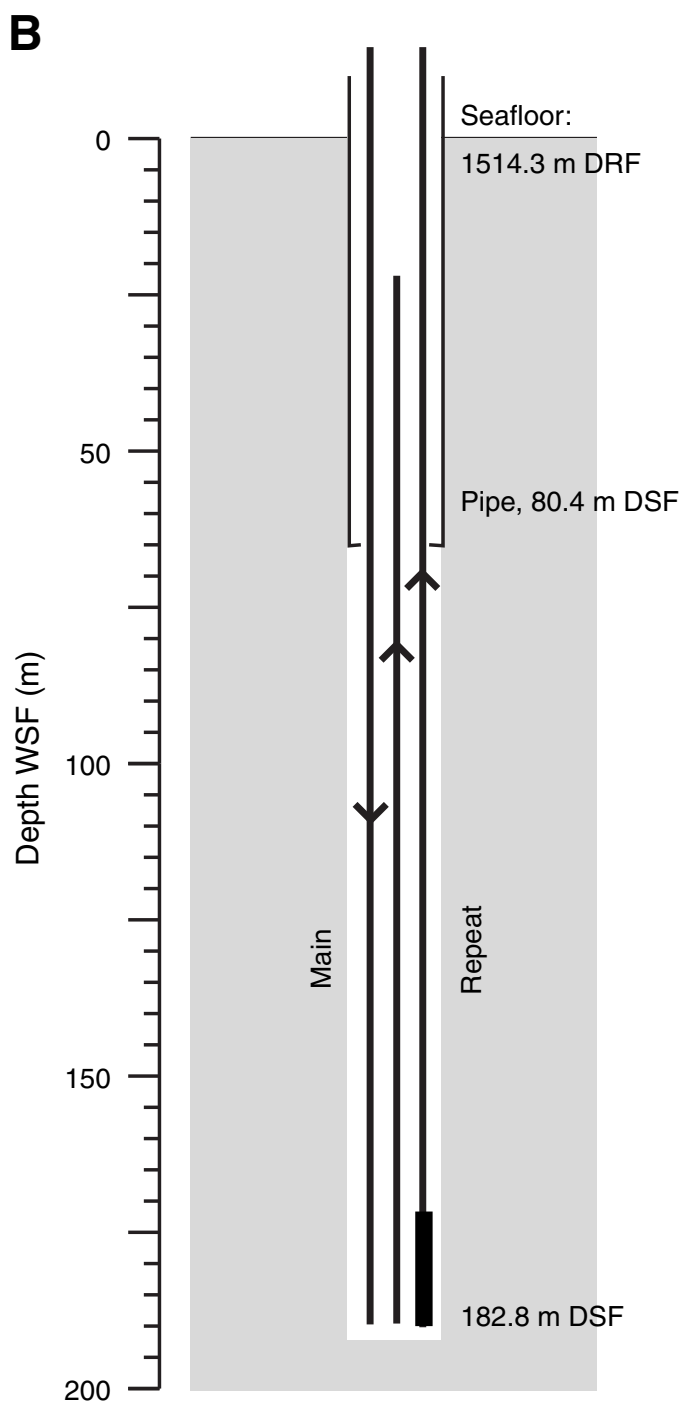


Figure F58. A. Göttingen Borehole Magnetometer (GBM) tool string. B. Schematic of Hole U1376A logging pass (one continuous log that starts and ends on rig floor).
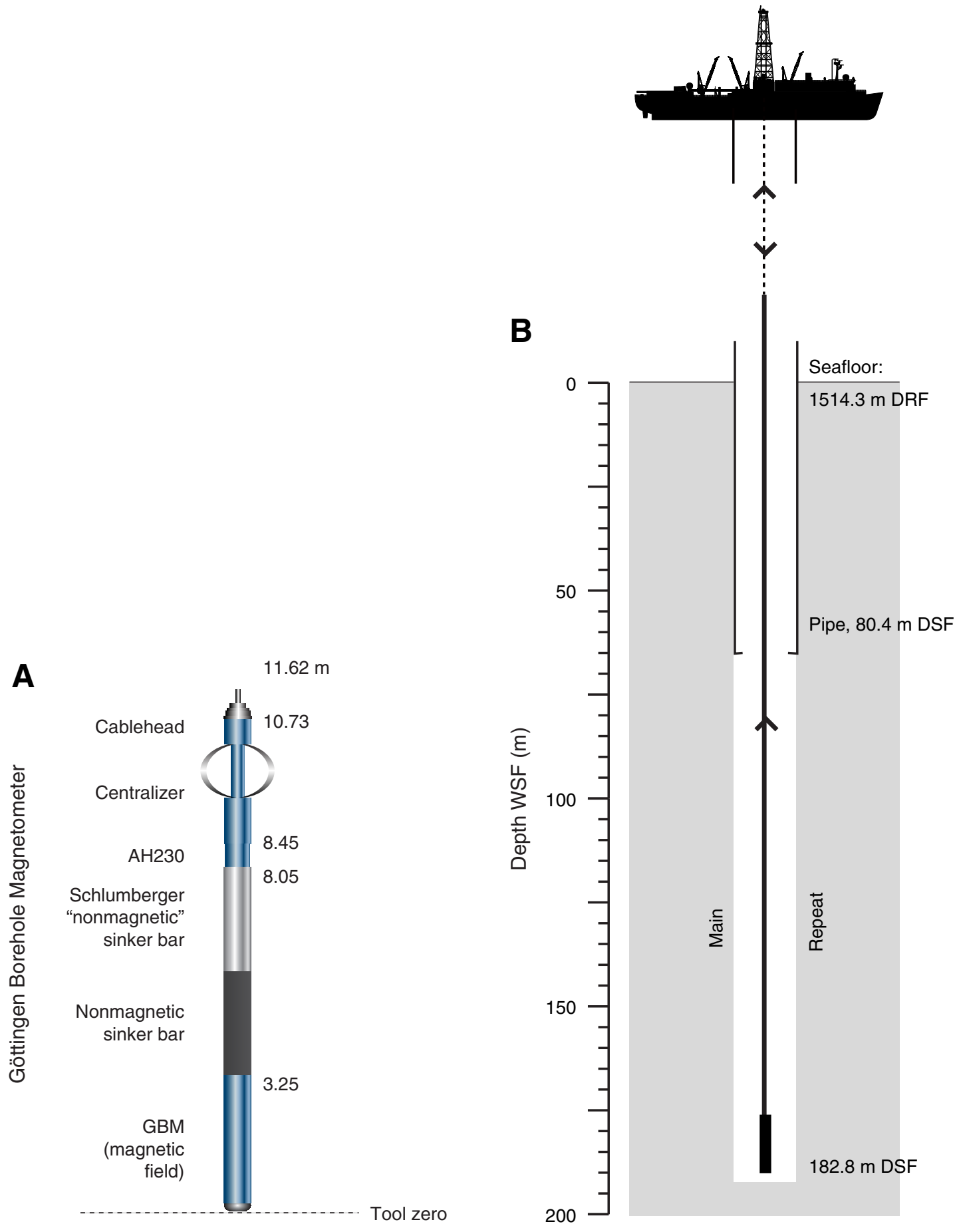
Figure F59. A. Formation MicroScanner (FMS)-sonic tool string. HNGS = Hostile Environment Natural Gamma Ray Sonde, DSI = Dipole Shear Sonic Imager, GPIT = General Purpose Inclinometry Tool. B. Schematic of Hole U1376A logging passes (two uplog passes).

A

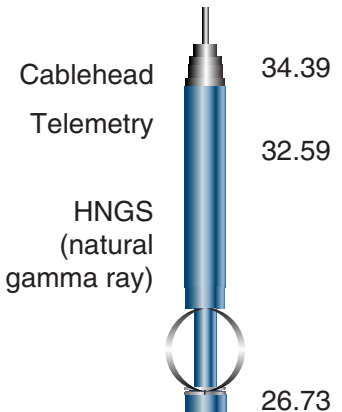

DSI

(acoustic velocity)

인

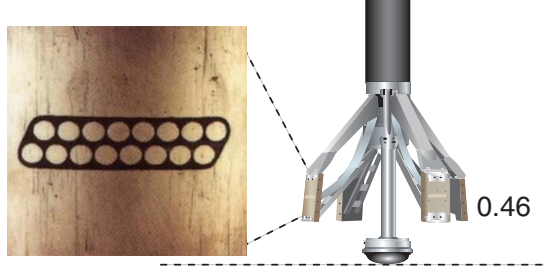

Tool zero

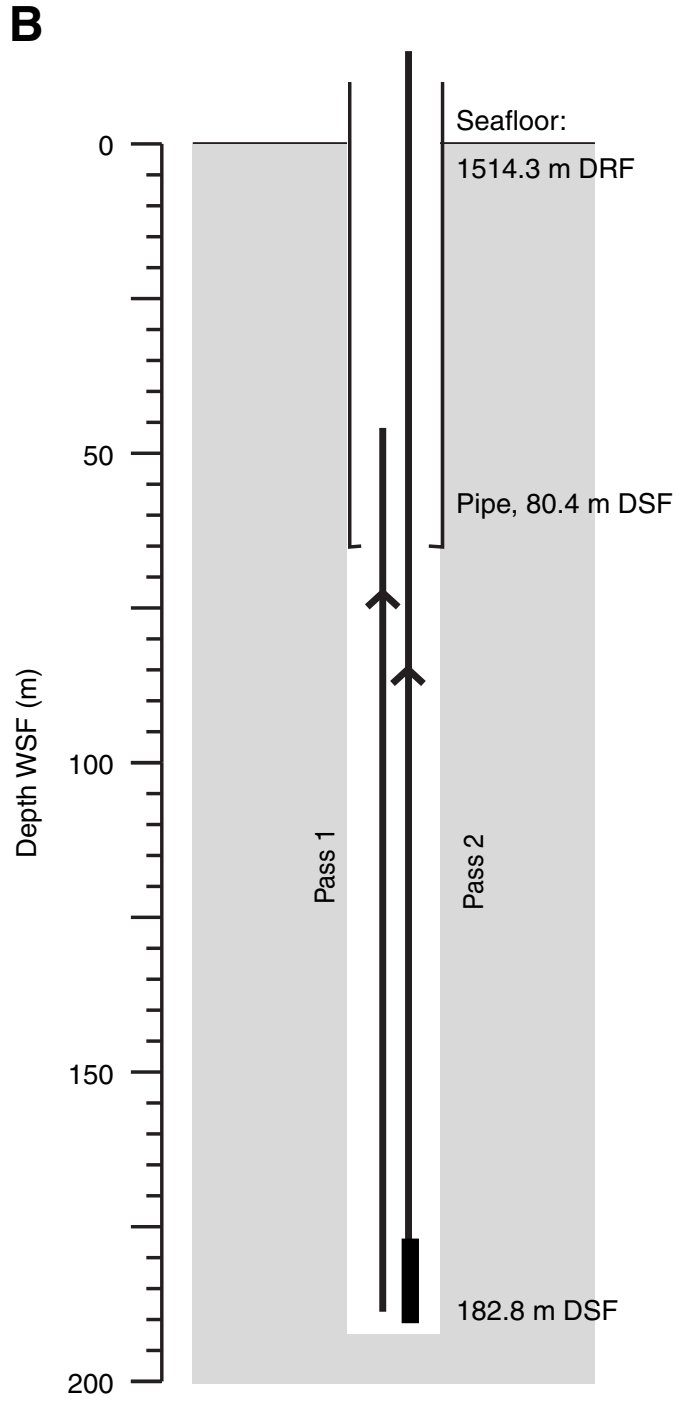


Figure F60. Summary of downhole log measurements and log unit divisions, Hole U1376A. Measurements include gamma ray (Pass $1=$ triple combo main pass, Pass $2=$ triple combo repeat pass [note that the very high gamma values observed in the pipe for Pass 2 are due to its activation by the neutron source during Pass 1]), caliper, density (moisture and density [MAD] measurements plotted using mbsf depth scale), resistivity (IMPH = medium induction phasor-processed resistivity, IDPH = deep induction phasor-processed resistivity), neutron porosity (APLC) and MAD porosity, and $P$-wave velocity (velocity core $=V_{\mathrm{P}}$ measured on discrete core samples [mbsf depth scale], $V_{\mathrm{P}}=$ compressional wave velocity measured with downhole sonic sonde [main and repeat runs]). A summary of core recovery and stratigraphic units is provided at far right (see Fig. F10 for explanation of abbreviations and patterns).

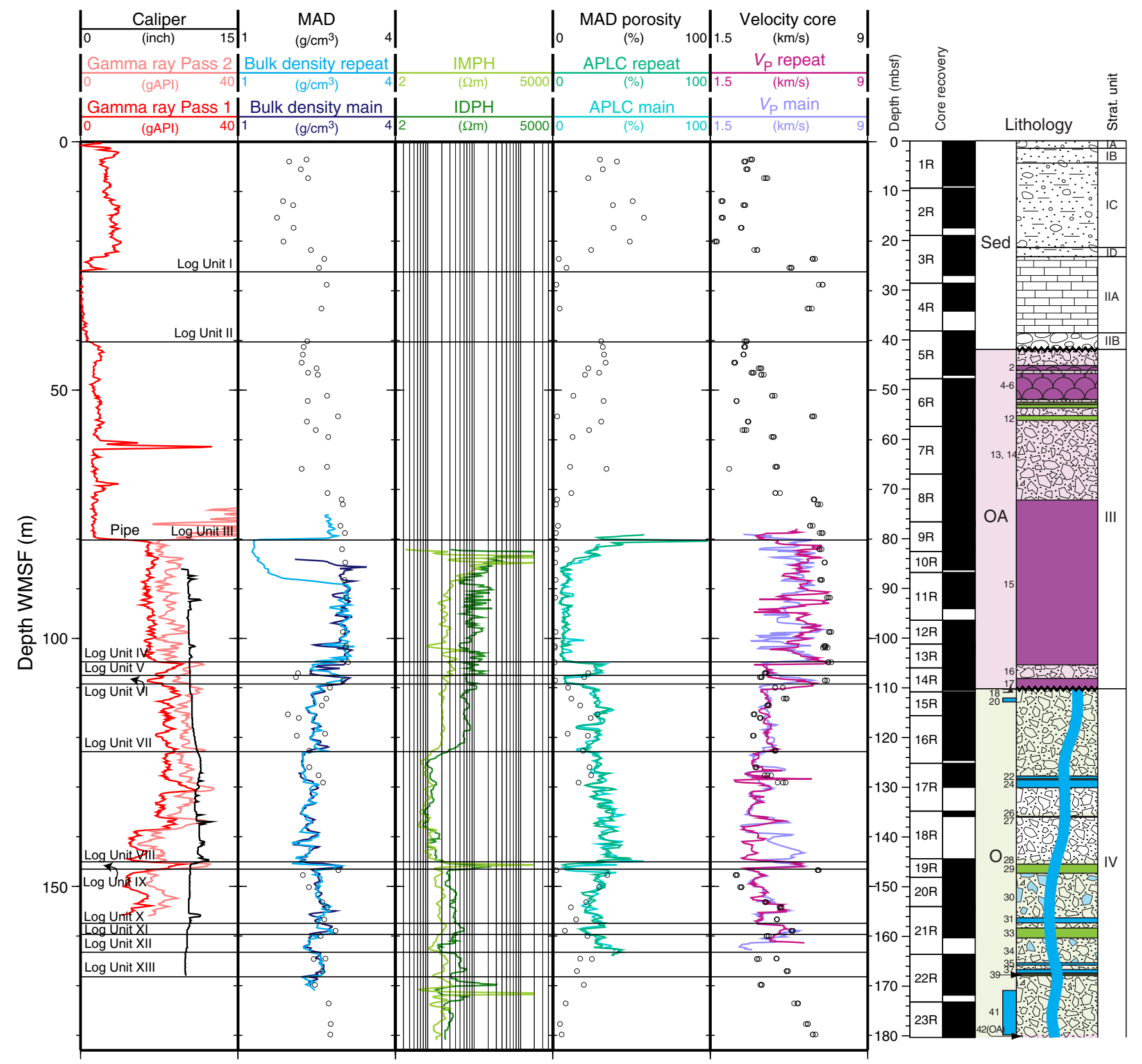


Figure F61. Summary of natural gamma ray log measurements, Hole U1376A. Note that natural gamma radiation (NGR; measured on whole-round cores) is in counts per second (cps), and all downhole measurements are in gAPI (American Petroleum Institute gamma ray units). Blue zone across figure denotes area of aphyric intrusions in massive nonbrecciated unit. A summary of core recovery and stratigraphic units is provided at far right (see Fig. F10 for explanation of abbreviations and patterns).

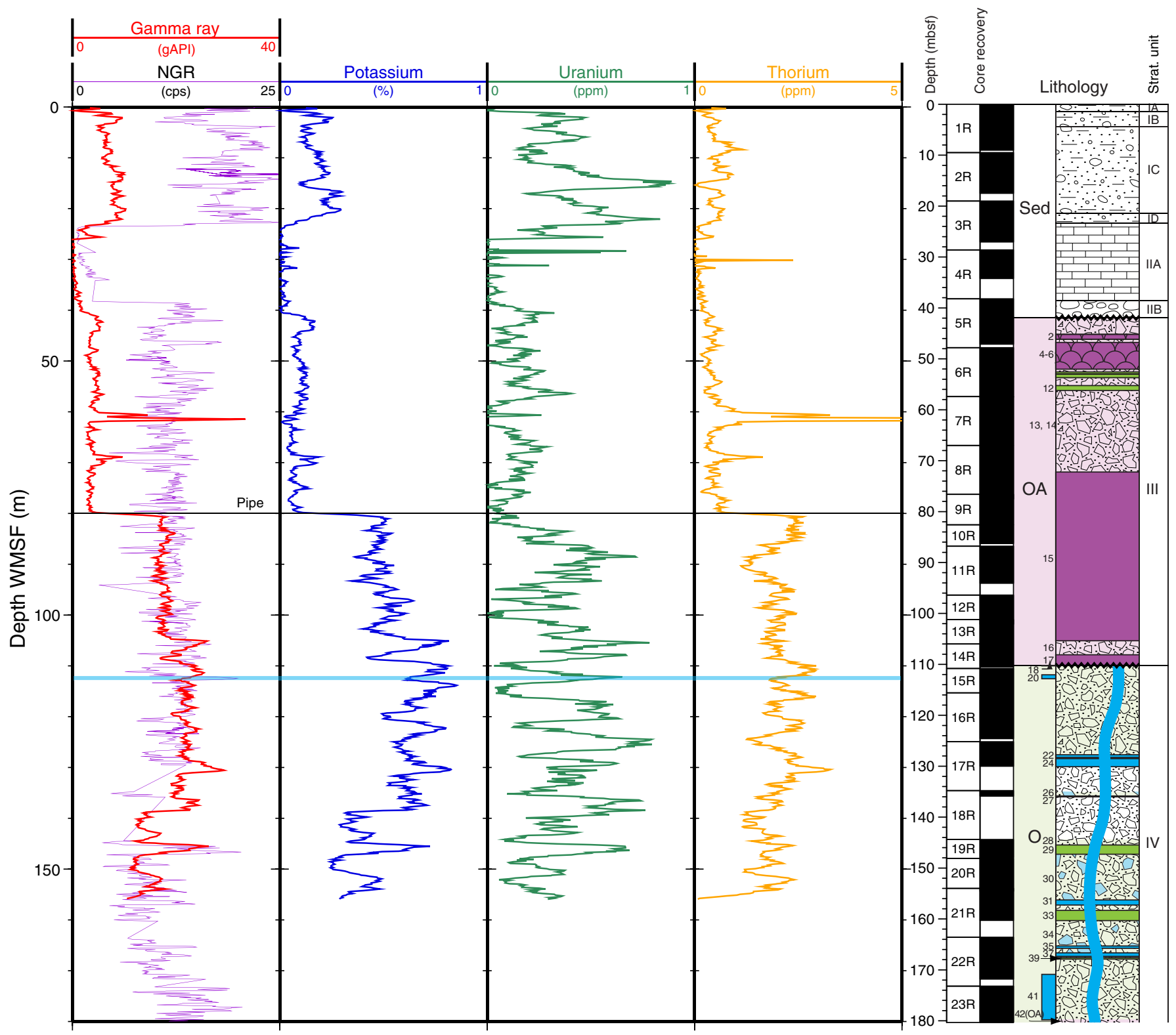


Figure F62. Plots of borehole deviation from vertical determined during Göttingen Borehole Magnetometer (GBM) run (downlog and uplog) and comparison with deviation determined by the General Purpose Inclinometry Tool (GPIT) in the Formation MicroScanner (FMS)-sonic tool string, Hole U1376A. The light colors in the GBM plot show raw data, and the dark colors show 16-point moving average, which is also shown in comparison plot.
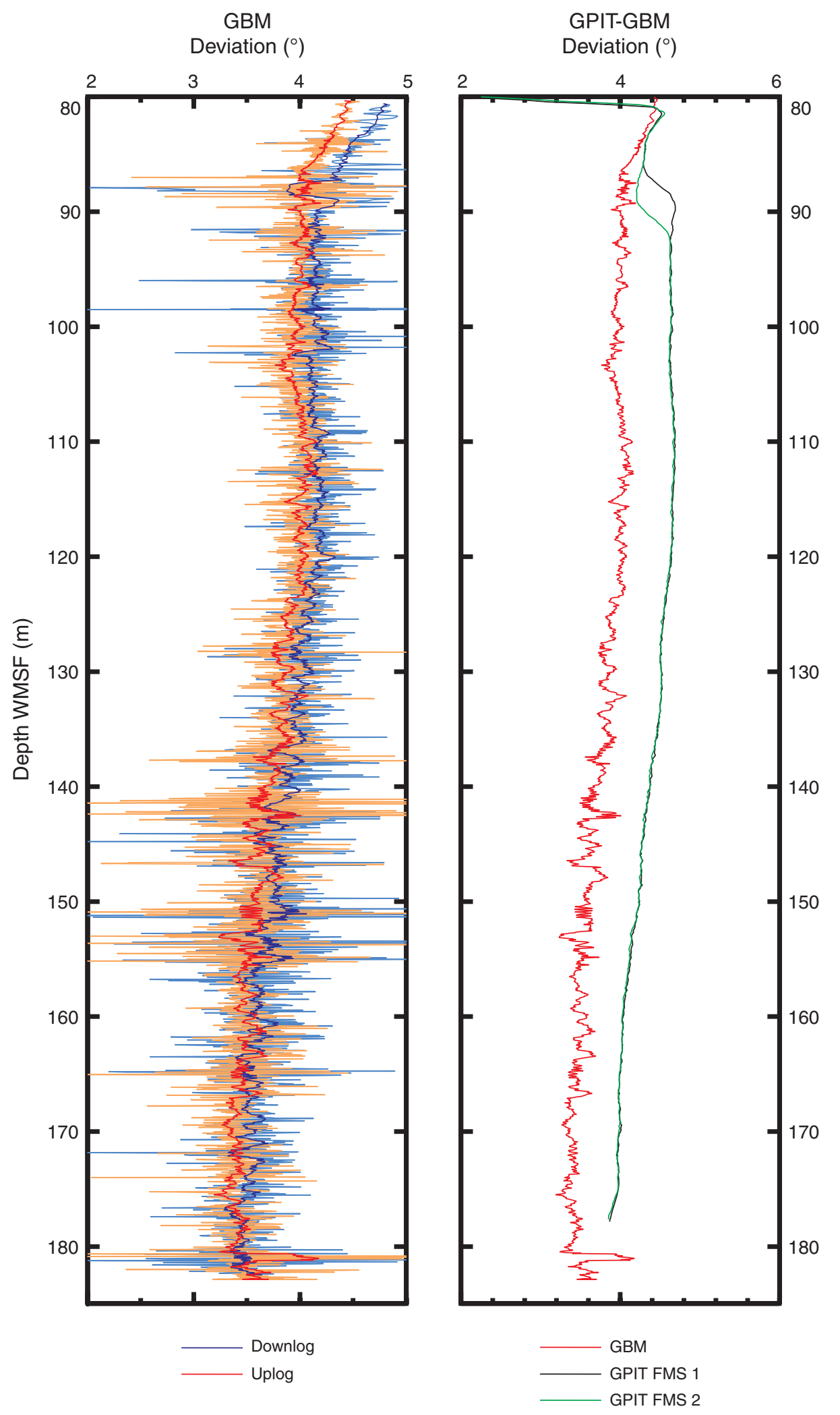
Figure F63. Raw horizontal magnetic field data for Göttingen Borehole Magnetometer (GBM) run (downlog and uplog) and comparison with horizontal magnetic field measured by the General Purpose Inclinometry Tool (GPIT) in the Formation MicroScanner (FMS)-sonic tool string, Hole U1376A. Data are not corrected for tool inclination.
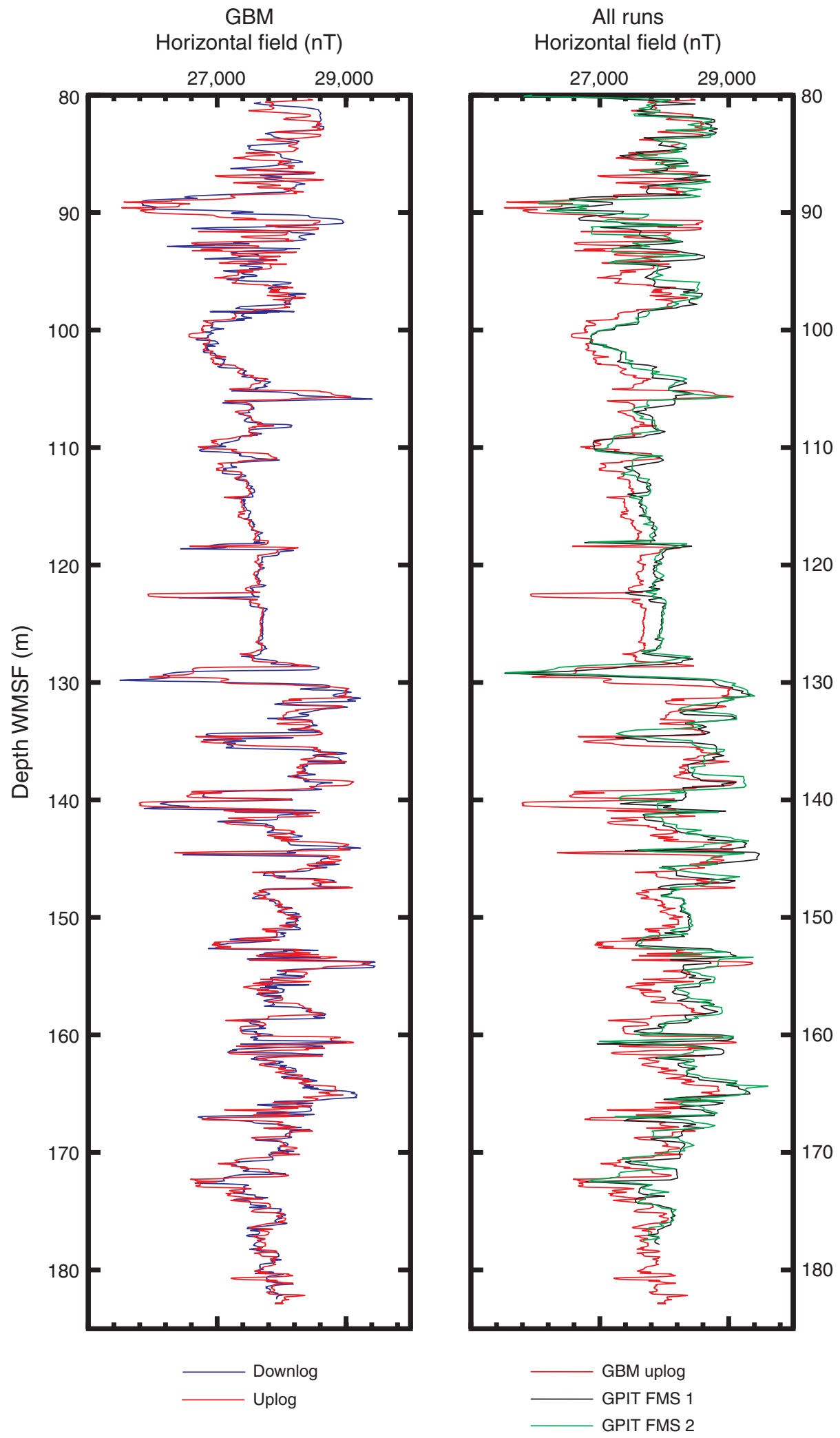
Figure F64. Raw vertical magnetic field data for Göttingen Borehole Magnetometer (GBM) run (downlog and uplog) and comparison with vertical magnetic field measured by the General Purpose Inclinometry Tool (GPIT) in the Formation MicroScanner (FMS)-sonic tool string, Hole U1376A. Data are not corrected for tool inclination. Offsets between logs can be explained by magnetic material present in GPIT tool strings.

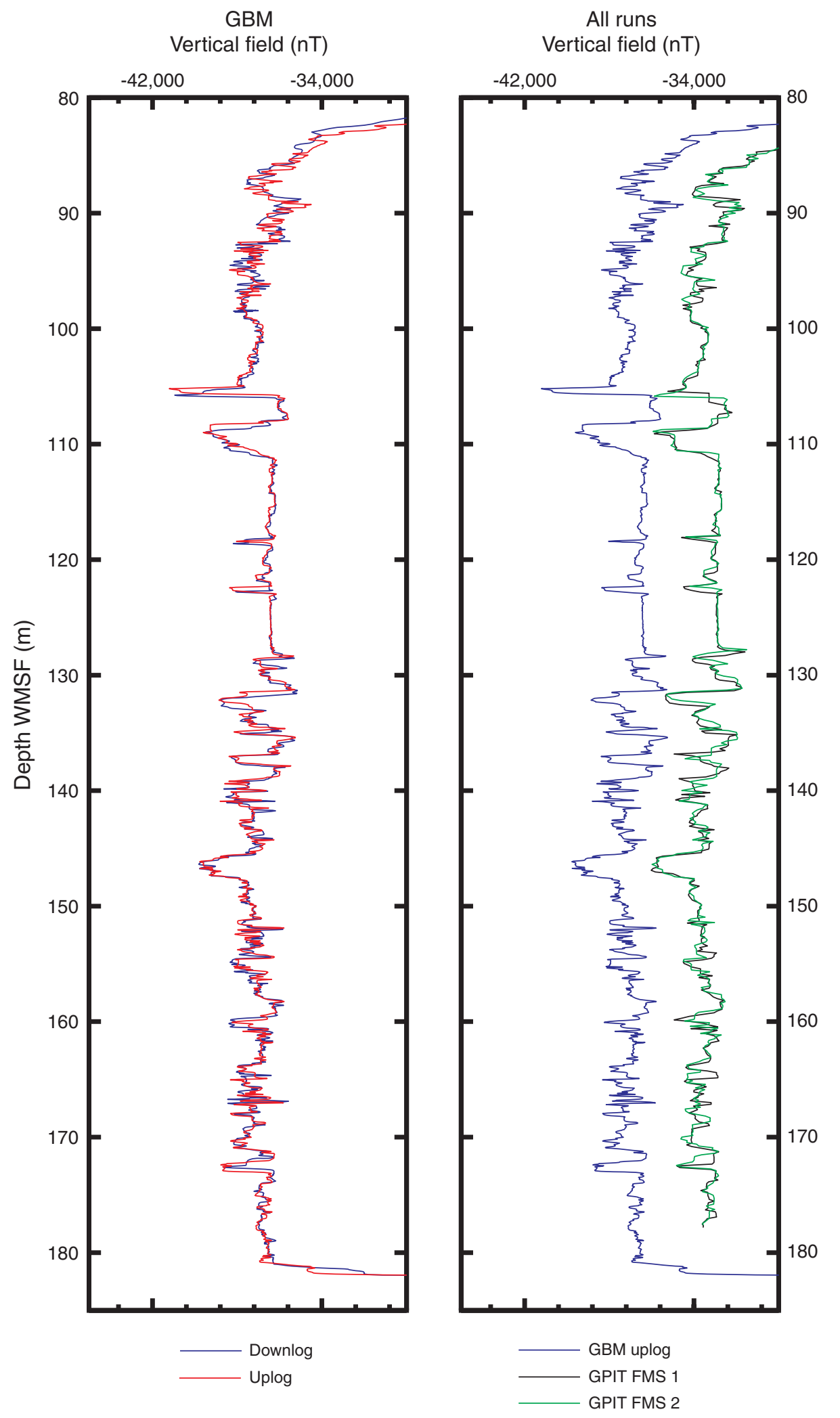


Figure F65. Magnetic field inclination determined by the General Purpose Inclinometry Tool (GPIT) in the Formation MicroScanner (FMS)-sonic tool string, Hole U1376A. Calculation of inclination is influenced by magnetic material in the tool string and the deviation of the hole from vertical. Note that the International Geomagnetic Reference Field (IGRF11) inclination at Site U1376 is $-55.7^{\circ}$.

Magnetic inclination $\left(^{\circ}\right)$

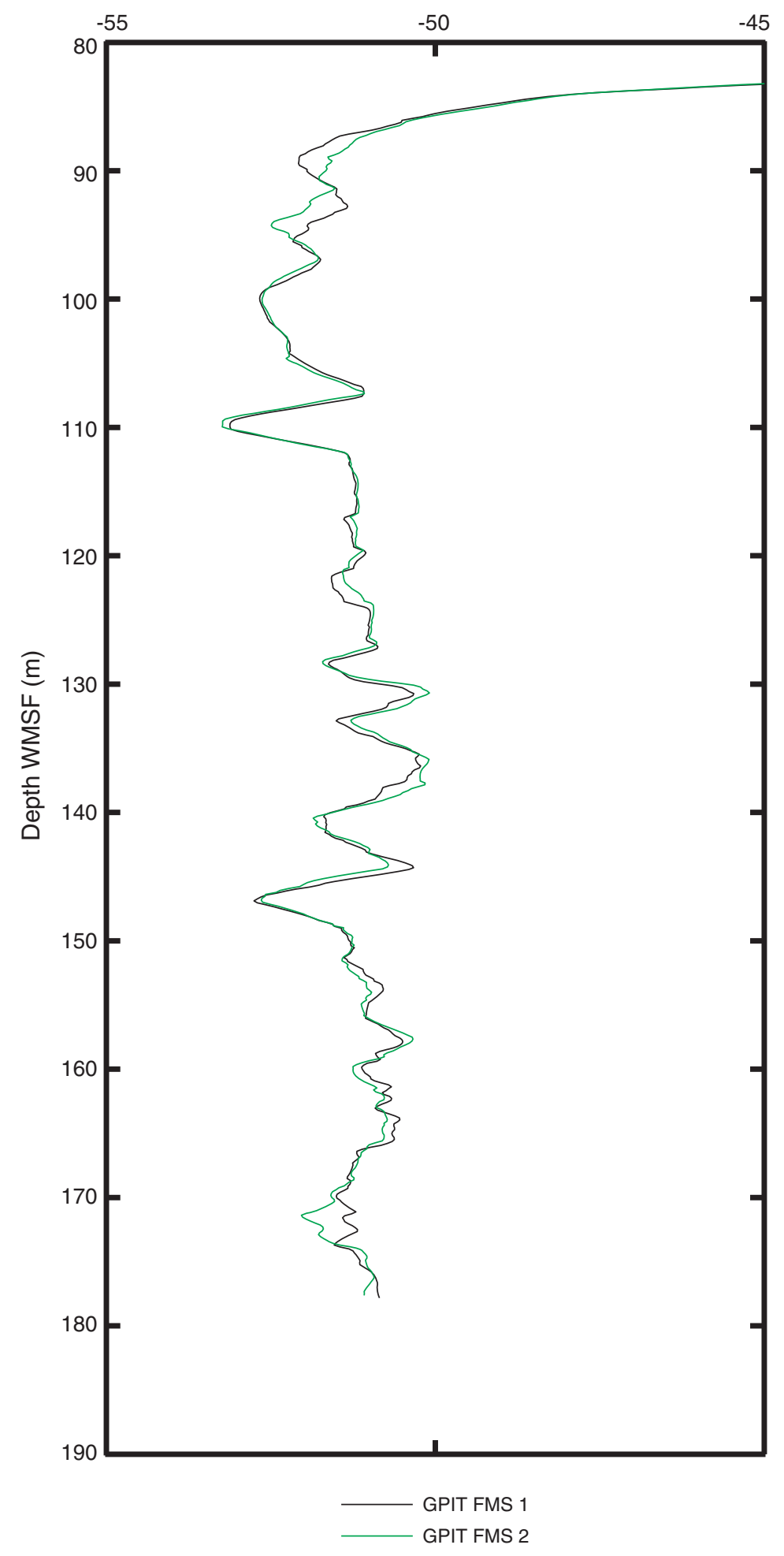


Figure F66. Accumulated angles of fiber-optic gyros for Göttingen Borehole Magnetometer (GBM) run, Hole U1376A. Rz is parallel to the symmetry axis of the tool, and $\mathrm{R} x$ and $\mathrm{R} y$ are perpendicular to $\mathrm{R} z$. In plot of $\mathrm{R} z$, green line $=$ downlog portion of the run. Data are not corrected for Earth's rotation.

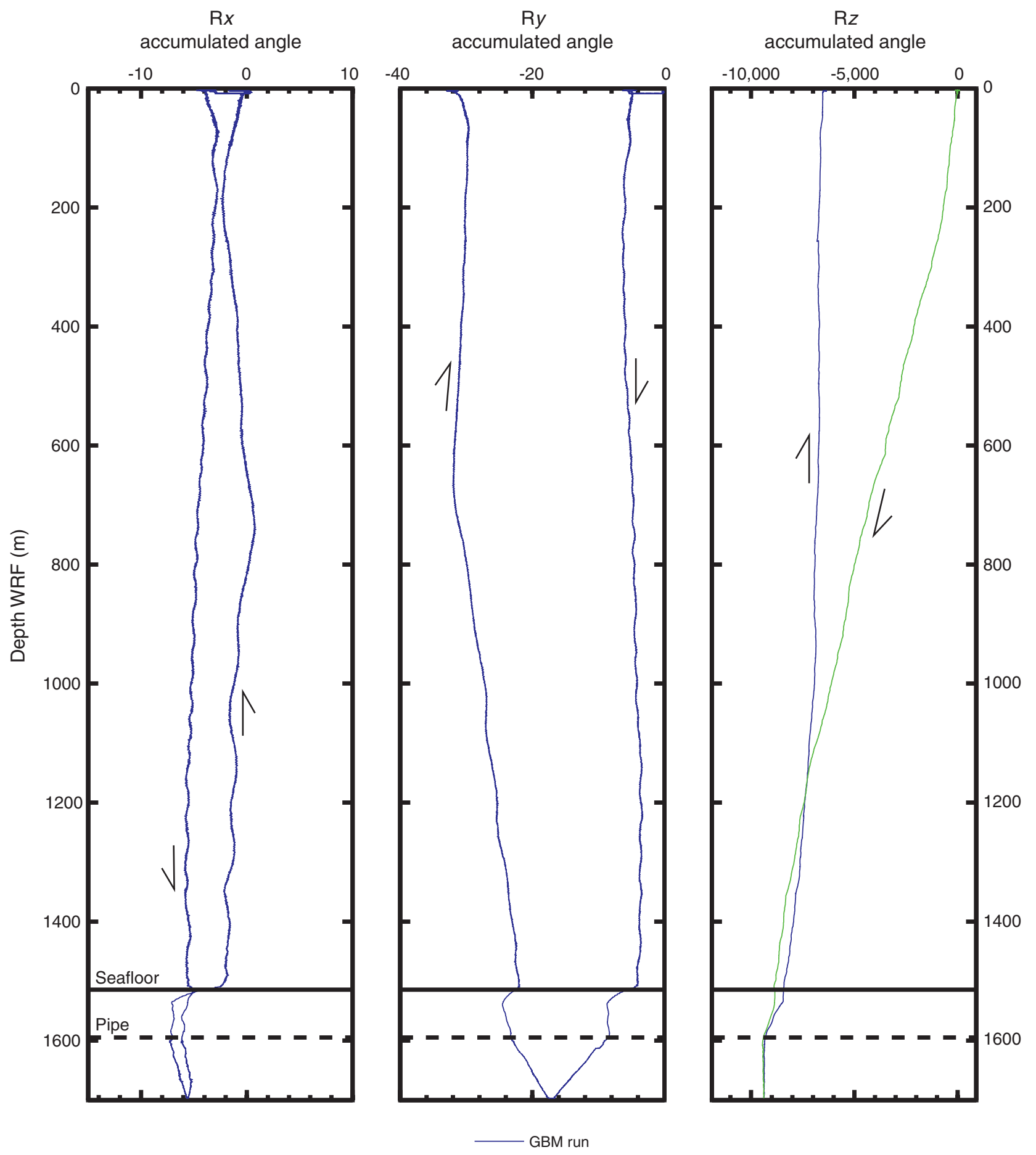


Figure F67. Comparison of raw magnetic field data (not corrected for tool inclination) of Göttingen Borehole Magnetometer (GBM) run with lithology, Hole U1376A (see Fig. F10 for explanation of abbreviations and patterns). Vertical black lines indicate ambient field, $\mathrm{H}=27,274 \mathrm{nT}$ and $\mathrm{Z}=-39,967 \mathrm{nT}$ (please note that these are estimations and are not corrected for borehole deviation).

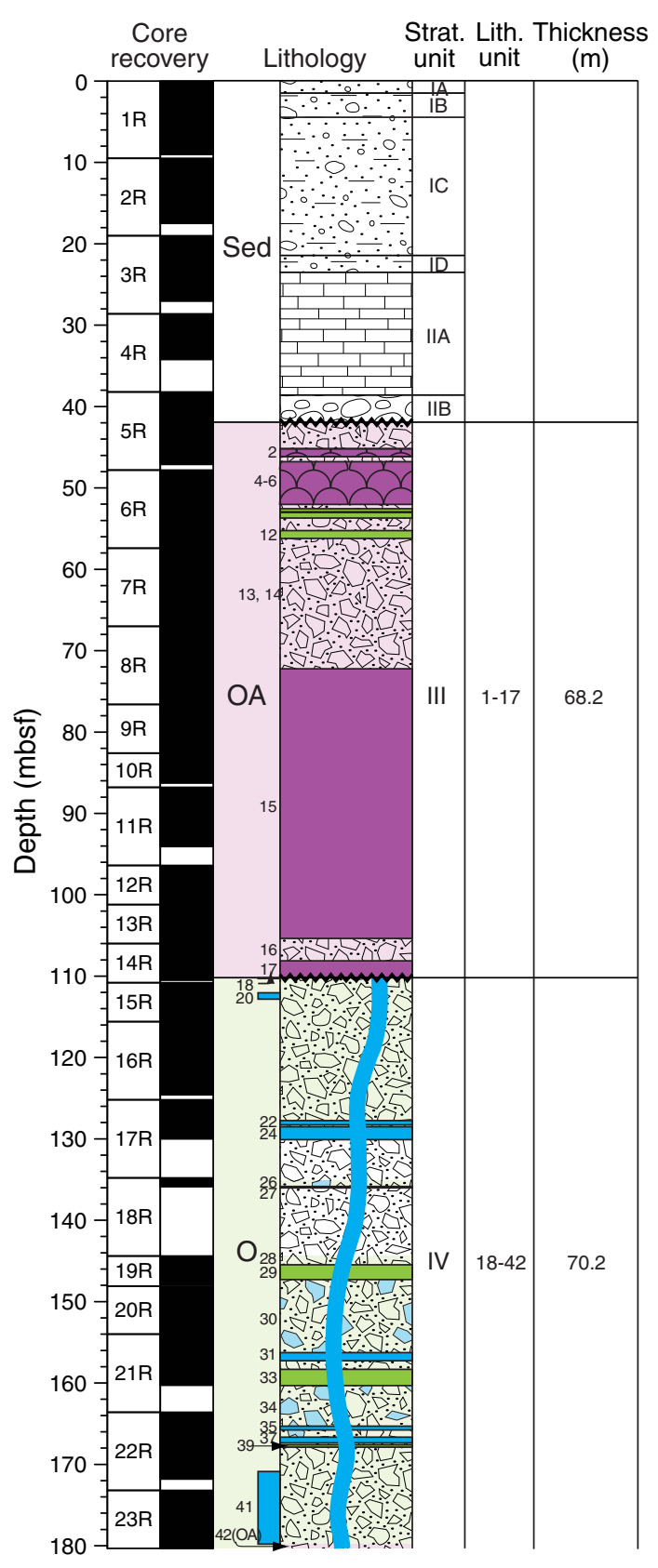

Horizontal field (nT)

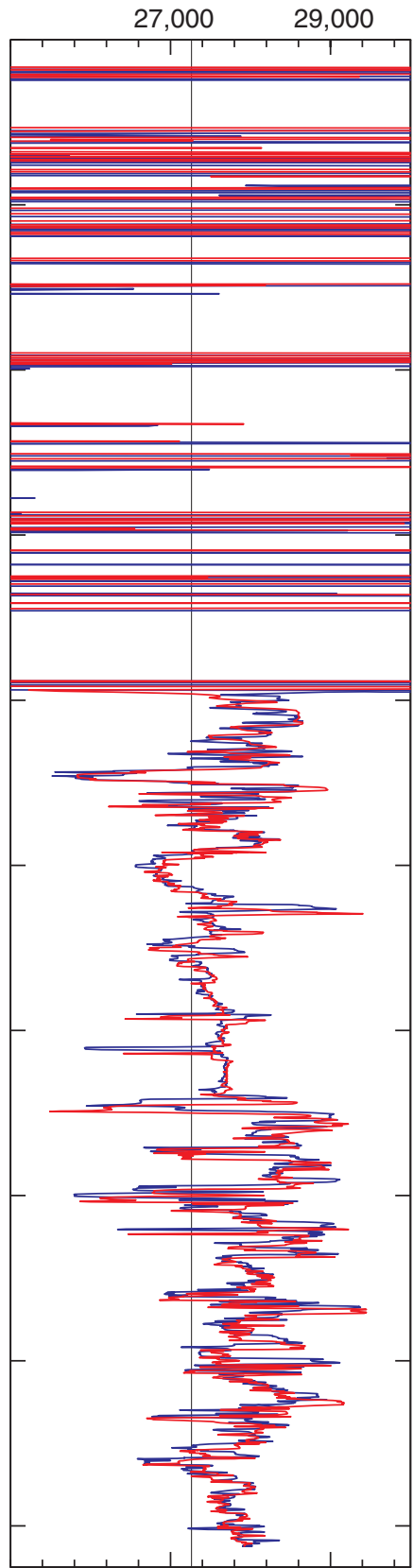

Vertical field (nT)

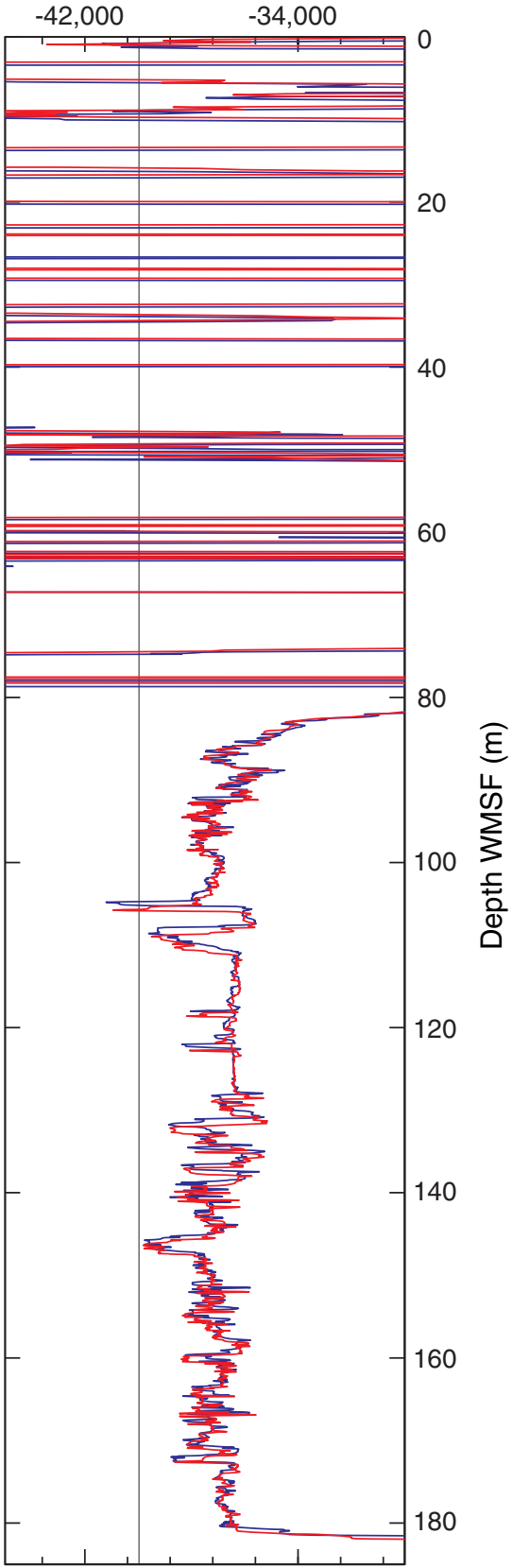


Figure F68. Composite showing Formation MicroScanner (FMS) images for mostly unrecovered section in Hole U1376A. FMS images are overlain by a high-resolution bulk density curve (in red). A. Entire section. B. Potential flow feature. C. Very blocky brecciated area. D. Highly resistive feature (potential lava lobe). E. Typical region toward base of unrecovered section.
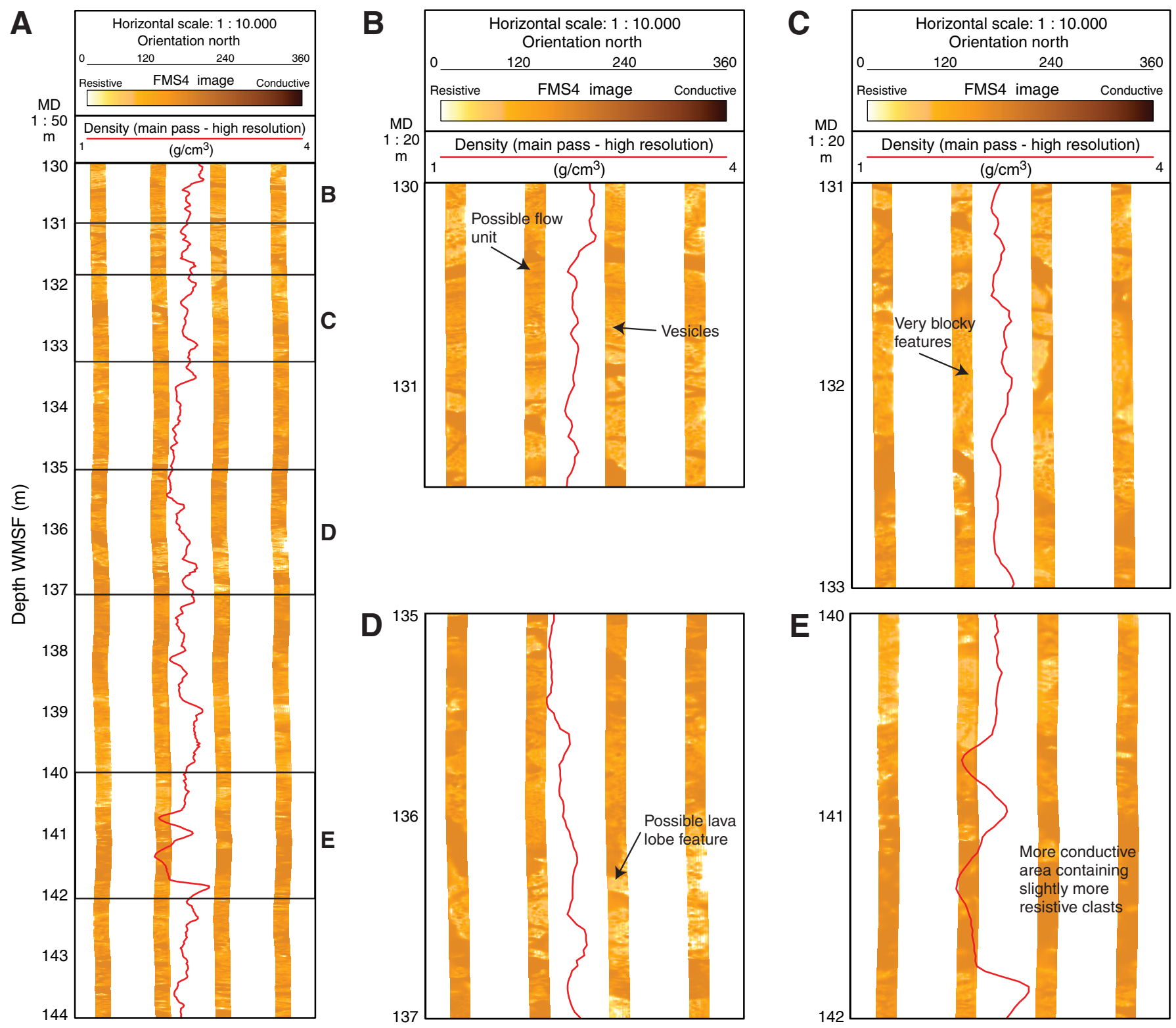
Figure F69. Composite of features imaged by Formation MicroScanner (FMS), Hole U1376A. Note that images here are shown from a single FMS pass. FMS images are overlain by a high-resolution bulk density curve (in red). A. Very resistive massive basalt unit and associated conductive fractures. B. Basalt flow unit and underlying breccia unit. C. Two potential flow units not recovered in core. D. Highly resistive flow unit. E. Aphyric basalt flow unit. F. Aphyric and olivine-phyric flow units.
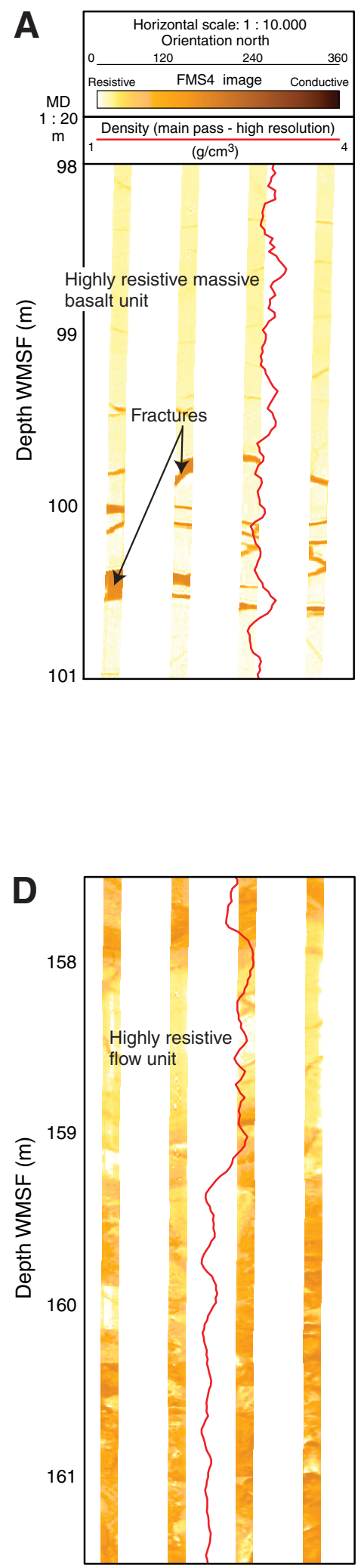
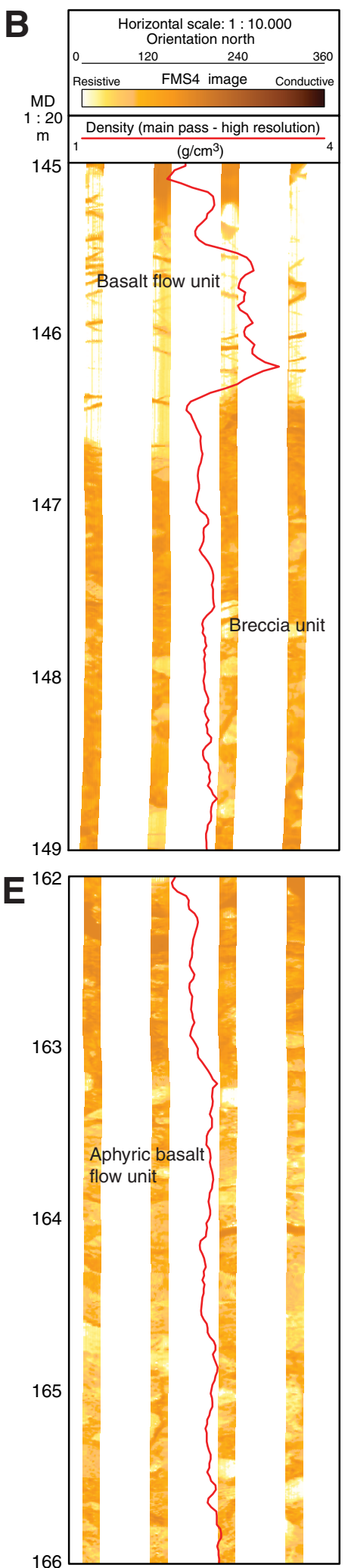

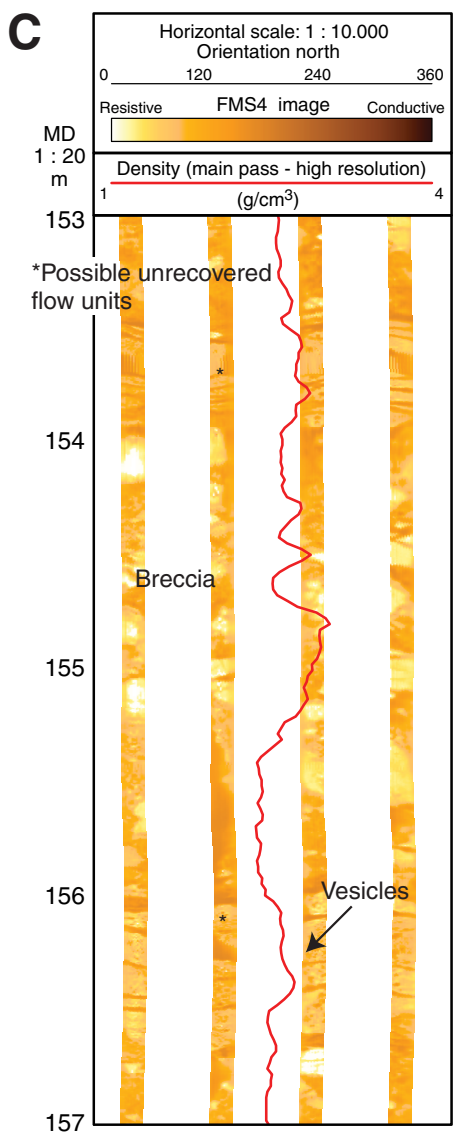

$\mathbf{F}$

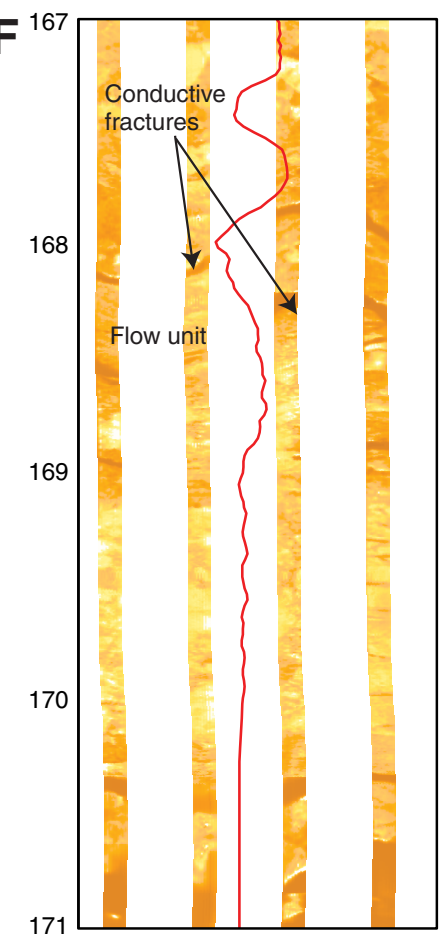


Figure F70. Summary figure of Formation MicroScanner (FMS) images showing examples of structural relationships, Hole U1376A. Note that images are from one FMS pass. Best-fit sinusoids were picked on major features (black = bed boundaries/unit boundaries, red = conductive fractures), and tadpole plots of dip angles and directions are shown next to FMS image (note that direction of tadpole tail indicates true azimuth of dip, and angle of dip is where circle is plotted). Both static- and dynamic-normalized FMS images are shown. A. Numerous conductive fractures in massive basalt unit. B, C. Boundaries on either side of flow units in stratigraphic Unit IV. D. Top surface of lithologic Unit 41. For more details on aforementioned lithologic and stratigraphic units, see "Igneous petrology and volcanology." (Figure shown on next page.) 

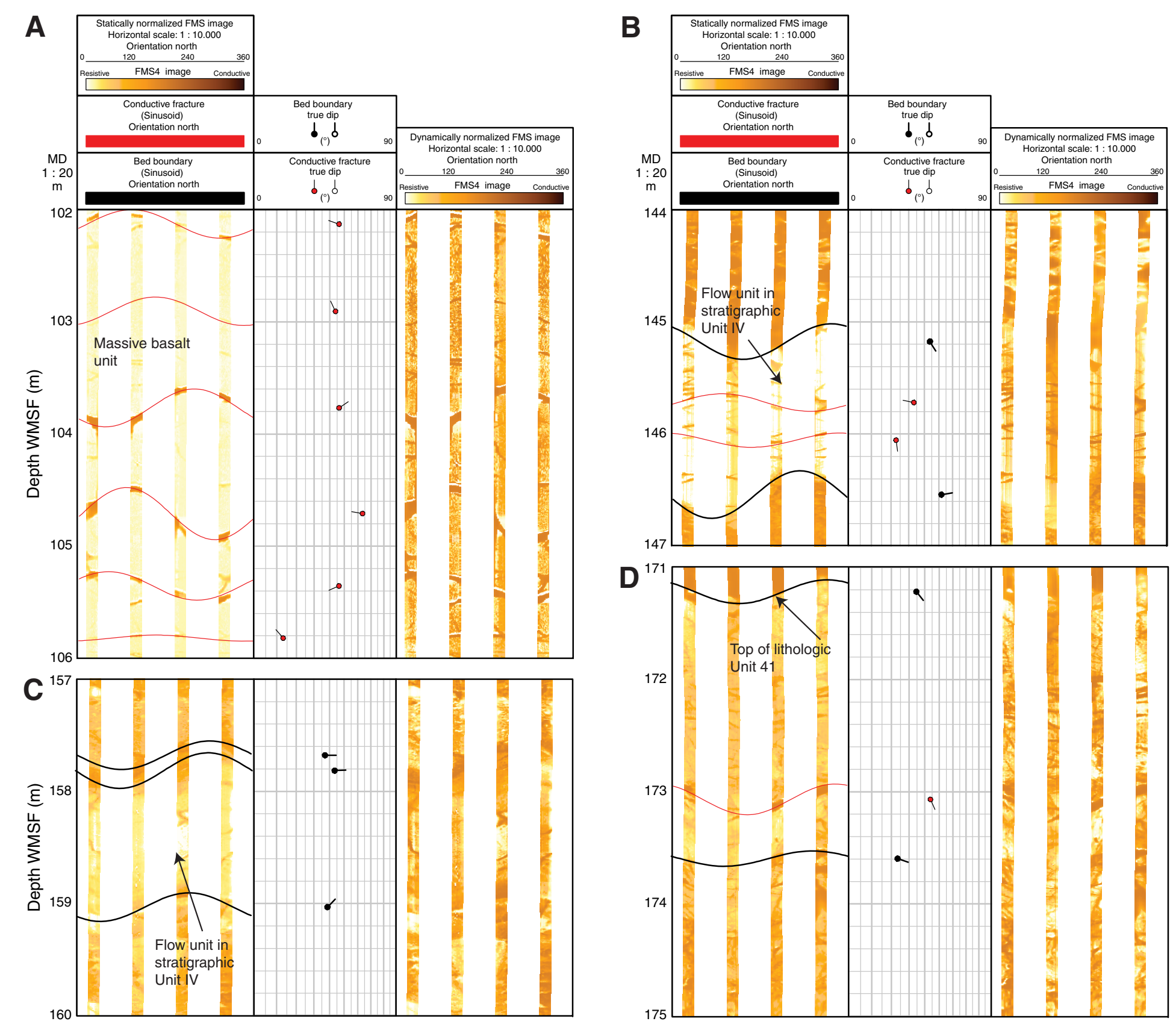
Figure F71. Schematic showing locations of microbiology (MBIO) samples, Hole U1376A. ISCI = in situ confidence index (see "Igneous petrology and volcanology" in the "Methods" chapter [Expedition 330 Scientists, 2012a]).

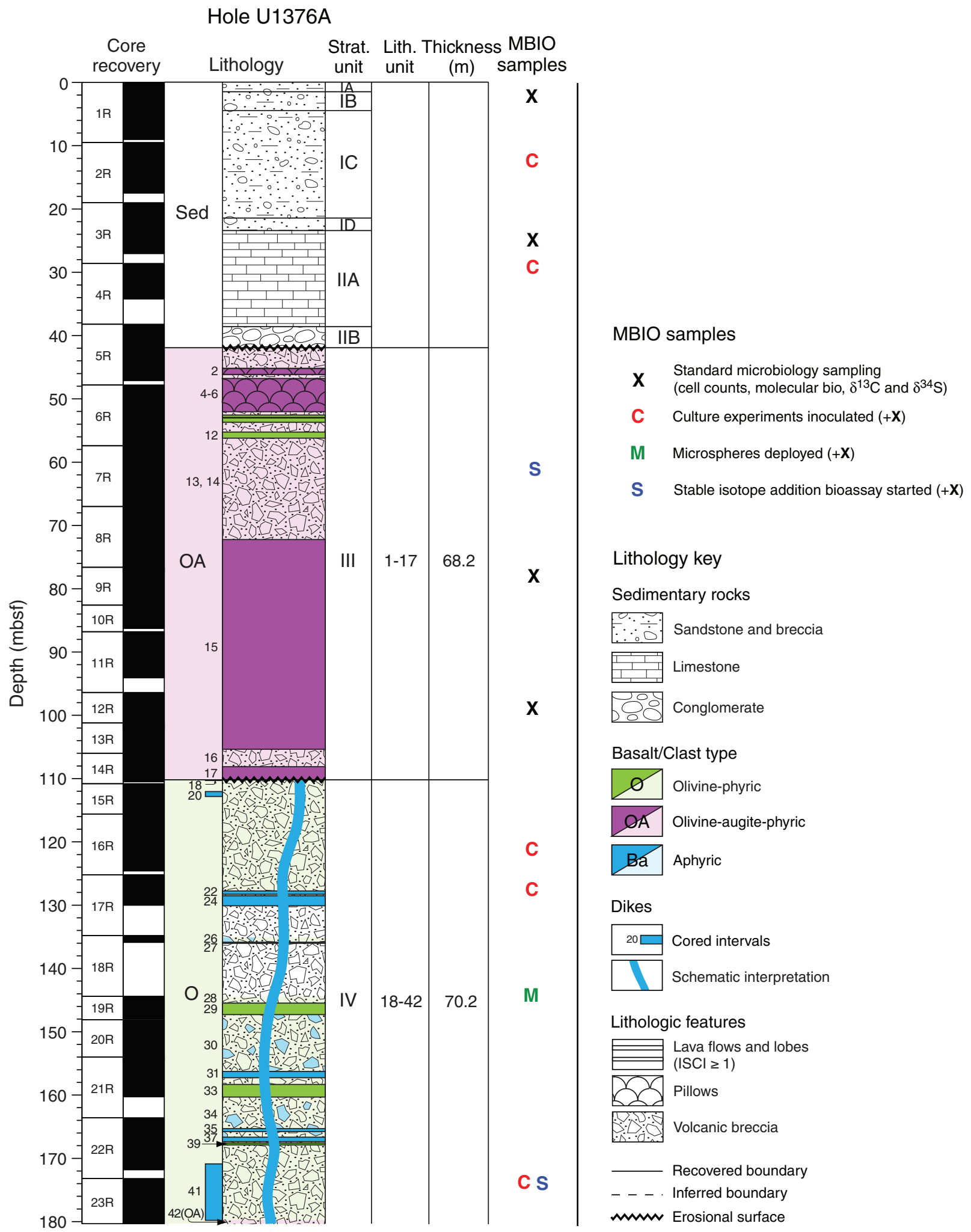


Figure F72. Whole-round samples collected for microbiology analysis, Site U1376. (Continued on next page.)

\begin{tabular}{|c|c|c|c|}
\hline $\begin{array}{l}\text { Core, section, } \\
\text { interval }(\mathrm{cm})\end{array}$ & $\begin{array}{l}\text { Depth } \\
\text { (mbsf) }\end{array}$ & Lithology & Photograph \\
\hline \multicolumn{4}{|l|}{ 330-U1376A- } \\
\hline 1R-2, 50-60 & 1.95 & $\begin{array}{l}\text { Volcanic } \\
\text { sandstone }\end{array}$ & \\
\hline 2R-3, 0-6 & 12.23 & $\begin{array}{l}\text { Sandy } \\
\text { volcanic } \\
\text { sandstone }\end{array}$ & \\
\hline 3R-5, 80-89 & 24.86 & $\begin{array}{l}\text { Limestone } \\
\text { (boundstone) }\end{array}$ & \\
\hline $4 R-1,35-42$ & 28.95 & $\begin{array}{l}\text { Limestone } \\
\text { (boundstone) }\end{array}$ & \\
\hline 7R-3, 59-71 & 60.73 & $\begin{array}{l}\text { Olivine-augite- } \\
\text { phyric volcanic } \\
\text { breccia }\end{array}$ & \\
\hline 9R-2, 23-35 & 78.12 & $\begin{array}{l}\text { Olivine-augite- } \\
\text { phyric basalt }\end{array}$ & \\
\hline
\end{tabular}


Figure F72 (continued).

\begin{tabular}{|c|c|c|c|}
\hline $\begin{array}{l}\text { Core, section, } \\
\text { interval }(\mathrm{cm})\end{array}$ & $\begin{array}{l}\text { Depth } \\
\text { (mbsf) }\end{array}$ & Lithology & Photograph \\
\hline 330-U1376A- & & & \\
\hline $12 \mathrm{R}-2,120-132$ & 98.86 & $\begin{array}{l}\text { Olivine-augite- } \\
\text { phyric basalt }\end{array}$ & \\
\hline $16 \mathrm{R}-5,0-13$ & 120.78 & $\begin{array}{l}\text { Olivine-phyric } \\
\text { volcanic breccia }\end{array}$ & \\
\hline $17 \mathrm{R}-2,112-120$ & 127.76 & $\begin{array}{l}\text { Aphyric basalt } \\
\text { (lava lobe or } \\
\text { fragment) }\end{array}$ & \\
\hline 19R-1, 20-28 & 144.6 & $\begin{array}{l}\text { Olivine-phyric } \\
\text { volcanic breccia }\end{array}$ & \\
\hline 23R-1, 102-114 & 174.22 & $\begin{array}{l}\text { Aphyric basalt } \\
\text { (intrusive sheet) }\end{array}$ & \\
\hline
\end{tabular}


Table T1. Coring summary, Site U1376.

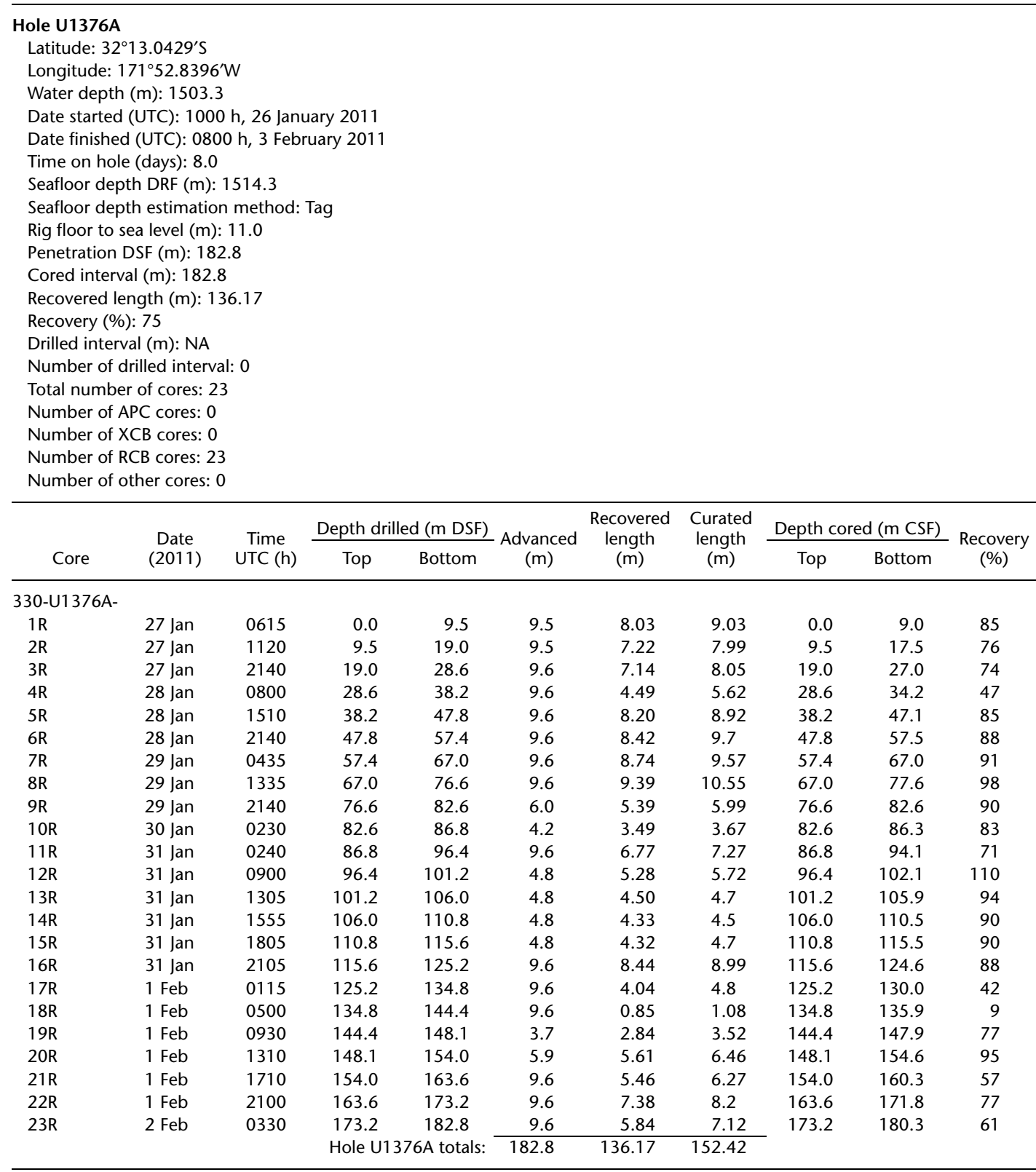

$\mathrm{NA}=$ not applicable. UTC $=$ universal time coordinated. DRF $=$ drilling depth below rig floor, DSF $=$ drilling depth below seafloor, $C S F=$ core depth below seafloor. $A P C=$ advanced piston corer (core type $H), X C B=$ extended core barrel (core type $X$ ), $R C B=$ rotary core barrel $($ core type R). 
Table T2. Distribution of Cenozoic calcareous nannofossils, Hole U1376A.

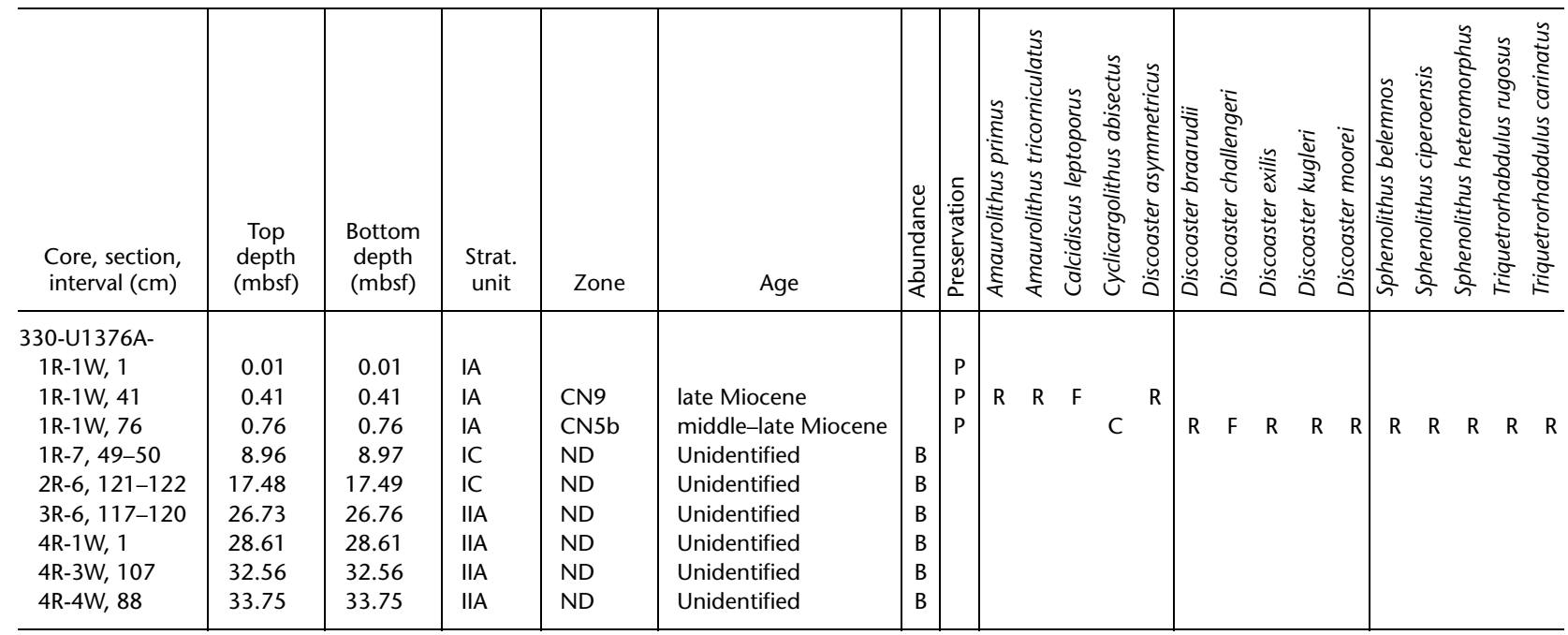

$\mathrm{ND}=$ not defined. Abundance: $\mathrm{C}=$ common, $\mathrm{F}=$ few, $\mathrm{R}=$ rare, $\mathrm{B}=$ barren. Preservation: $\mathrm{P}=$ poor.

Table T3. Distribution of planktonic foraminifers, Hole U1376A.

\begin{tabular}{|c|c|c|c|c|c|}
\hline $\begin{array}{l}\text { Core, section, } \\
\text { interval }(\mathrm{cm})\end{array}$ & $\begin{array}{l}\text { Top } \\
\text { depth } \\
\text { (mbsf) }\end{array}$ & $\begin{array}{l}\text { Bottom } \\
\text { depth } \\
\text { (mbsf) }\end{array}$ & $\begin{array}{l}\text { Strat. } \\
\text { unit }\end{array}$ & Zone & Age \\
\hline $\begin{array}{r}330-U 1376 A- \\
1 \mathrm{R}-7,49-50\end{array}$ & 8.96 & 8.97 & IC & ND & Unidentified \\
\hline $2 \mathrm{R}-6,121-122$ & 17.47 & 17.48 & IC & ND & Unidentified \\
\hline $3 R-6,117-120$ & 26.73 & 26.76 & IIA & ND & Unidentified \\
\hline 4R-4, 36-39 & 33.23 & 33.26 & IIA & ND & Unidentified \\
\hline
\end{tabular}

$\mathrm{ND}=$ not defined. Abundance: $\mathrm{B}=$ barren .

Table T4. Distribution of macro- and microfossils observed in thin section, Hole U1376A.

\begin{tabular}{|c|c|c|c|c|c|c|c|c|}
\hline $\begin{array}{l}\text { Core, section, } \\
\text { interval }(\mathrm{cm})\end{array}$ & $\begin{array}{l}\text { Top } \\
\text { depth } \\
\text { (mbsf) }\end{array}$ & $\begin{array}{c}\text { Bottom } \\
\text { depth } \\
\text { (mbsf) }\end{array}$ & $\begin{array}{l}\text { Strat. } \\
\text { unit }\end{array}$ & Zone & Age & 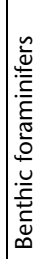 & $\begin{array}{l} \\
\frac{n}{\bar{U}} \\
\frac{0}{0} \\
\frac{0}{0} \\
\frac{\pi}{2}\end{array}$ & 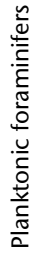 \\
\hline \multicolumn{9}{|l|}{ 330-U1376A- } \\
\hline 3R-4W, 129-133 & 23.82 & 23.86 & IIA & ND & Unidentified & & $\mathrm{P}$ & B \\
\hline 3R-5W, 99-103 & 25.05 & 25.09 & $\| A$ & ND & Unidentified & & $\mathrm{P}$ & $\mathrm{P}$ \\
\hline 4R-1W, 45-49 & 29.05 & 29.09 & IIA & ND & Unidentified & B & $\mathrm{P}$ & B \\
\hline $4 \mathrm{R}-2 \mathrm{~W}, 55-58$ & 30.59 & 31.02 & IIA & ND & Unidentified & $P$ & $\mathrm{P}$ & B \\
\hline $4 \mathrm{R}-3 \mathrm{~W}, 65-68$ & 32.14 & 32.17 & IIB & ND & Unidentified & B & $\mathrm{P}$ & B \\
\hline $5 R-1 W, 65-67$ & 38.85 & 38.87 & IIB & ND & Unidentified & B & $\mathrm{P}$ & $\mathrm{P}$ \\
\hline $5 R-2 W, 80-83$ & 40.17 & 40.20 & IIB & ND & Unidentified & B & $\mathrm{P}$ & B \\
\hline
\end{tabular}

$\mathrm{ND}=$ not defined. $\mathrm{P}=$ present (number of individuals was not counted), $\mathrm{B}=$ barren. 
Table T5. In situ confidence index (ISCI) for igneous lithologic units, Site U1376.

\begin{tabular}{|c|c|c|c|c|}
\hline $\begin{array}{l}\text { Lith. } \\
\text { unit }\end{array}$ & $\mathrm{ISCl}$ & $\begin{array}{l}\text { Core, section, } \\
\text { interval }(\mathrm{cm})\end{array}$ & Unit description & $\begin{array}{l}\text { Strat. } \\
\text { unit }\end{array}$ \\
\hline & & 330-U1376A- & & \\
\hline 1 & NA & $5 R-3,122$, to $5 R-6,31$ & Hyaloclastite breccia & III \\
\hline 2 & 1 & $5 R-6,31$, to $5 R-7,2$ & Vesicular lobate flow or pillow & III \\
\hline 3 & NA & $5 R-7,2$, to $5 R-7,62$ & Heterolithic basalt breccia & III \\
\hline 4 & 3 & $5 \mathrm{R}-7,62$, to $6 \mathrm{R}-3,8$ & Pillow basalt with thin breccia intervals & III \\
\hline 5 & 3 & $6 \mathrm{R}-3,8$, to $6 \mathrm{R}-3,119$ & Pillow basalt & III \\
\hline 6 & 3 & $6 \mathrm{R}-3,119$, to $6 \mathrm{R}-4,38$ & Pillow basalt with thin breccia intervals & III \\
\hline 7 & NA & $6 \mathrm{R}-4,38$, to $6 \mathrm{R}-4,95$ & Basalt breccia and hyaloclastite & III \\
\hline 8 & 1 & $6 \mathrm{R}-4,95$, to $6 \mathrm{R}-4,132$ & Basalt (clast) & III \\
\hline 9 & NA & $6 \mathrm{R}-4,132$, to $6 \mathrm{R}-5,7$ & Basalt breccia and hyaloclastite & III \\
\hline 10 & 1 & $6 \mathrm{R}-5,7$, to $6 \mathrm{R}-5,75$ & Basalt (clast) & III \\
\hline 11 & NA & $6 \mathrm{R}-5,75$, to $6 \mathrm{R}-6,87$ & Basalt breccia and hyaloclastite & III \\
\hline 12 & 1 & $6 \mathrm{R}-6,87$, to $6 \mathrm{R}-7,22.5$ & Basalt (clast) & III \\
\hline 13 & NA & $6 \mathrm{R}-7,22.5$, to $6 \mathrm{R}-8,40$ & Basalt breccia and hyaloclastite & III \\
\hline 14 & 2 & $7 R-1,0$, to $8 R-4,135$ & Pillow basalt breccia and hyaloclastite & III \\
\hline 15 & 3 & $8 \mathrm{R}-5,0$, to $13 \mathrm{R}-4,59$ & Lava flow & III \\
\hline 16 & NA & $13 R-4,59$, to $14 R-2,84$ & Hyaloclastite breccia & III \\
\hline 17 & 3 & $14 \mathrm{R}-2,84$, to $14 \mathrm{R}-4,47$ & Massive basalt & III \\
\hline 18 & 1 & $14 \mathrm{R}-4,47$, to $14 \mathrm{R}-4,55$ & Intrusive sheet & Dike \\
\hline 19 & NA & $14 \mathrm{R}-4,55$, to $15 \mathrm{R}-1,120$ & Hyaloclastite breccia & IV \\
\hline 20 & 3 & $15 R-2,0$, to $15 R-2,78$ & Intrusive sheet & Dike \\
\hline 21 & NA & $15 \mathrm{R}-2,78$, to $17 \mathrm{R}-2,93$ & Hyaloclastite breccia & IV \\
\hline 22 & 1 & $17 \mathrm{R}-2,93$, to $17 \mathrm{R}-2,145$ & Lobate flow or fragment & IV \\
\hline 23 & NA & $17 \mathrm{R}-2,145$, to $17 \mathrm{R}-3,23$ & Hyaloclastite breccia & IV \\
\hline 24 & 2 & $17 \mathrm{R}-3,23$, to $17 \mathrm{R}-4,37$ & Lobate flow or fragment & IV \\
\hline 25 & 0 & $17 \mathrm{R}-4,37$, to $17 \mathrm{R}-4,44$ & Lobate flow or fragment & IV \\
\hline 26 & NA & $18 \mathrm{R}-1,0$, to $18 \mathrm{R}-1,87.5$ & Heterolithic basalt breccia & IV \\
\hline 27 & 0 & $18 \mathrm{R}-1,87.5$, to $18 \mathrm{R}-1,108$ & Lobate flow or fragment & IV \\
\hline 28 & NA & $19 \mathrm{R}-1,0$, to $19 \mathrm{R}-1,92$ & Hyaloclastite breccia & IV \\
\hline 29 & 3 & $19 \mathrm{R}-1,92$, to $19 \mathrm{R}-2,128$ & Lobate flow or fragment & IV \\
\hline 30 & NA & $19 \mathrm{R}-2,128$, to $21 \mathrm{R}-2,76$ & Heterolithic basalt breccia & IV \\
\hline 31 & 1 & $21 \mathrm{R}-2,76$, to $21 \mathrm{R}-3,61$ & Vesicular basalt lobate flow or fragment & IV \\
\hline 32 & NA & $21 \mathrm{R}-3,61$, to $21 \mathrm{R}-4,31.5$ & Volcanic breccia and hyaloclastite & IV \\
\hline 33 & 2 & $21 \mathrm{R}-4,31.5$, to $21 \mathrm{R}-5,89$ & Lobate flow or fragment & IV \\
\hline 34 & NA & $21 \mathrm{R}-5,89$, to $22 \mathrm{R}-2,21$ & Heterolithic basalt breccia with hyaloclastite matrix & IV \\
\hline 35 & 1 & $22 \mathrm{R}-2,21$, to $22 \mathrm{R}-2,67$ & Lobate flow or fragment & IV \\
\hline 36 & NA & $22 \mathrm{R}-2,67$, to $22 \mathrm{R}-3,9$ & Heterolithic basalt breccia with hyaloclastite matrix & IV \\
\hline 37 & 1 & $22 \mathrm{R}-3,9$, to $22 \mathrm{R}-3,82$ & Vesicular basalt lobate flow or fragment & IV \\
\hline 38 & NA & $22 \mathrm{R}-3,82$, to $22 \mathrm{R}-3,106$ & Volcanic breccia with hyaloclastite matrix & IV \\
\hline 39 & 1 & $22 \mathrm{R}-3,106$, to $22 \mathrm{R}-3,137$ & Lobate flow or fragment & IV \\
\hline 40 & NA & $22 \mathrm{R}-3,137$, to $22 \mathrm{R}-6,10$ & Volcanic breccia with hyaloclastite matrix & IV \\
\hline 41 & 3 & $22 \mathrm{R}-6,10$, to $23 \mathrm{R}-6,19$ & Intrusive sheet & Dike \\
\hline 42 & NA & $23 \mathrm{R}-6,19$, to $23 \mathrm{R}-6,75$ & Basalt breccia & IV \\
\hline
\end{tabular}

ISCI: 0 = unlikely to be in situ, 1 = could be in situ, 2 = probably in situ, 3 = highly likely to be in situ, NA = not applicable. See "Igneous petrology and volcanology" in the "Methods" chapter (Expedition 330 Scientists, 2012a) for a full explanation of the ISCI. 
Table T6. Occurrence of fresh or nearly fresh olivine and volcanic glass in thin section, Hole U1376A.

\begin{tabular}{|c|c|c|c|c|c|}
\hline Core, section & $\begin{array}{l}\text { Thin } \\
\text { section }\end{array}$ & $\begin{array}{l}\text { Depth } \\
\text { (mbsf) }\end{array}$ & Rocks & $\begin{array}{l}\text { Olivine freshness } \\
\text { (\%) }\end{array}$ & $\begin{array}{l}\text { Glass freshness } \\
\text { (\%) }\end{array}$ \\
\hline \multicolumn{6}{|l|}{ 330-U1376A- } \\
\hline 1R-4 & 234 & 4.59 & Clast in sediment & 5 & - \\
\hline $6 \mathrm{R}-6$ & 253 & 55.65 & Basalt & 60 & 25 \\
\hline $8 \mathrm{R}-6$ & 255 & 74.90 & Massive basalt & 95 & - \\
\hline $10 \mathrm{R}-3$ & 256 & 86.24 & Massive basalt & 95 & - \\
\hline $13 \mathrm{R}-4$ & 257 & 104.76 & Basalt lava flow & 95 & - \\
\hline $14 \mathrm{R}-3$ & 258 & 109.28 & Massive basalt & 95 & - \\
\hline $15 R-3$ & 260 & 113.81 & Hyaloclastite breccia & - & 70 \\
\hline 16R-2 & 261 & 116.79 & Hyaloclastite breccia & 30 & - \\
\hline 17R-1 & 262 & 126.60 & Hyaloclastite breccia & - & 95 \\
\hline $21 \mathrm{R}-1$ & 266 & 154.41 & Hyaloclastite breccia & - & 5 \\
\hline $21 \mathrm{R}-4$ & 267 & 158.63 & Basalt lava lobe or fragment & 40 & - \\
\hline
\end{tabular}

$-=$ no data.

Table T7. Geopetal structures, Hole U1376A.

\begin{tabular}{lcc}
\hline $\begin{array}{c}\text { Core, section, } \\
\text { interval (cm) }\end{array}$ & $\begin{array}{c}\text { Depth } \\
(\text { mbsf) }\end{array}$ & $\begin{array}{c}\text { Angle on } \\
\text { core face } \\
\left({ }^{\circ}\right)\end{array}$ \\
\hline 330-U1376A- & & \\
3R-4A, 47 & 23.00 & 0 \\
3R-4A, 101 & 23.54 & 2 \\
3R-6A, 60.5 & 26.17 & 0 \\
4R-1A, 23 & 28.83 & 0 \\
4R-1A, 53 & 29.13 & 0 \\
4R-2A, 120 & 31.24 & 0 \\
4R-2A, 135 & 31.39 & 0 \\
4R-3A, 5 & 31.54 & 0 \\
4R-3A, 6 & 31.55 & 0 \\
4R-3A, 7 & 31.56 & 0 \\
4R-3A, 104 & 32.53 & 1 \\
4R-3A, 115 & 32.64 & 3 \\
4R-4A, 27 & 33.14 & 1 \\
4R-4A, 73 & 33.60 & 1 \\
4R-4A, 78.5 & 33.66 & 1 \\
4R-4A, 103 & 33.90 & 0 \\
5R-1A, 28 & 38.48 & 4 \\
5R-1A, 31.5 & 38.52 & 0 \\
5R-1A, 82 & 39.02 & 6 \\
5R-1A, 83 & 39.03 & 0 \\
5R-1A, 83.5 & 39.04 & 8 \\
5R-1A, 91.5 & 39.12 & 4 \\
5R-3A, 98 & 41.69 & 2 \\
5R-3A, 103 & 41.74 & 1 \\
10R-3A, 45 & 85.48 & 5 \\
\hline & & \\
\hline
\end{tabular}

Most geopetals are within $4^{\circ}$ from horizontal as viewed on the archive-half core face. Geopetals from 39.02 to 39.12 mbsf (Section 330-U1376A$5 \mathrm{R}-1$ ) were recorded in the vesicular top of a large clast; angles vary from $0^{\circ}$ to $8^{\circ}$ on either side of horizontal (Fig. F37), resulting in an overall average of $\sim 0^{\circ}$. 
Table T8. Rocks with flow alignment textures, Hole U1376A.

\begin{tabular}{|c|c|c|c|c|c|c|}
\hline $\begin{array}{l}\text { Core, section, } \\
\text { interval }(\mathrm{cm})\end{array}$ & $\begin{array}{l}\text { Depth } \\
\text { (mbsf) }\end{array}$ & $\begin{array}{c}\text { Flow } \\
\text { interval } \\
(\mathrm{cm})\end{array}$ & $\begin{array}{l}\text { Flow/Clast/ } \\
\text { Intrusion }\end{array}$ & Direction* & Strength & $\begin{array}{l}\text { Thin section } \\
\text { (where present) }\end{array}$ \\
\hline \multicolumn{7}{|l|}{ 330-U1376A- } \\
\hline $5 R-1,47-65$ & 38.7 & $47-65$ & Clast & NA & Strong & \\
\hline $5 \mathrm{R}-2 \mathrm{~W}, 125-127$ & 40.6 & $123-134$ & Clast & NA & Strong & 246 \\
\hline $5 R-3,1-16$ & 40.8 & $1-16$ & Clast & NA & Strong & \\
\hline $14 \mathrm{R}-3 \mathrm{~W}, 84-86$ & 109.3 & $84-86$ & Lava flow & Subhorizontal & Weak & 258 \\
\hline
\end{tabular}

* = not applicable (NA) in clasts. 
Table T9. Whole-rock major and trace element compositions, Hole U1376A.

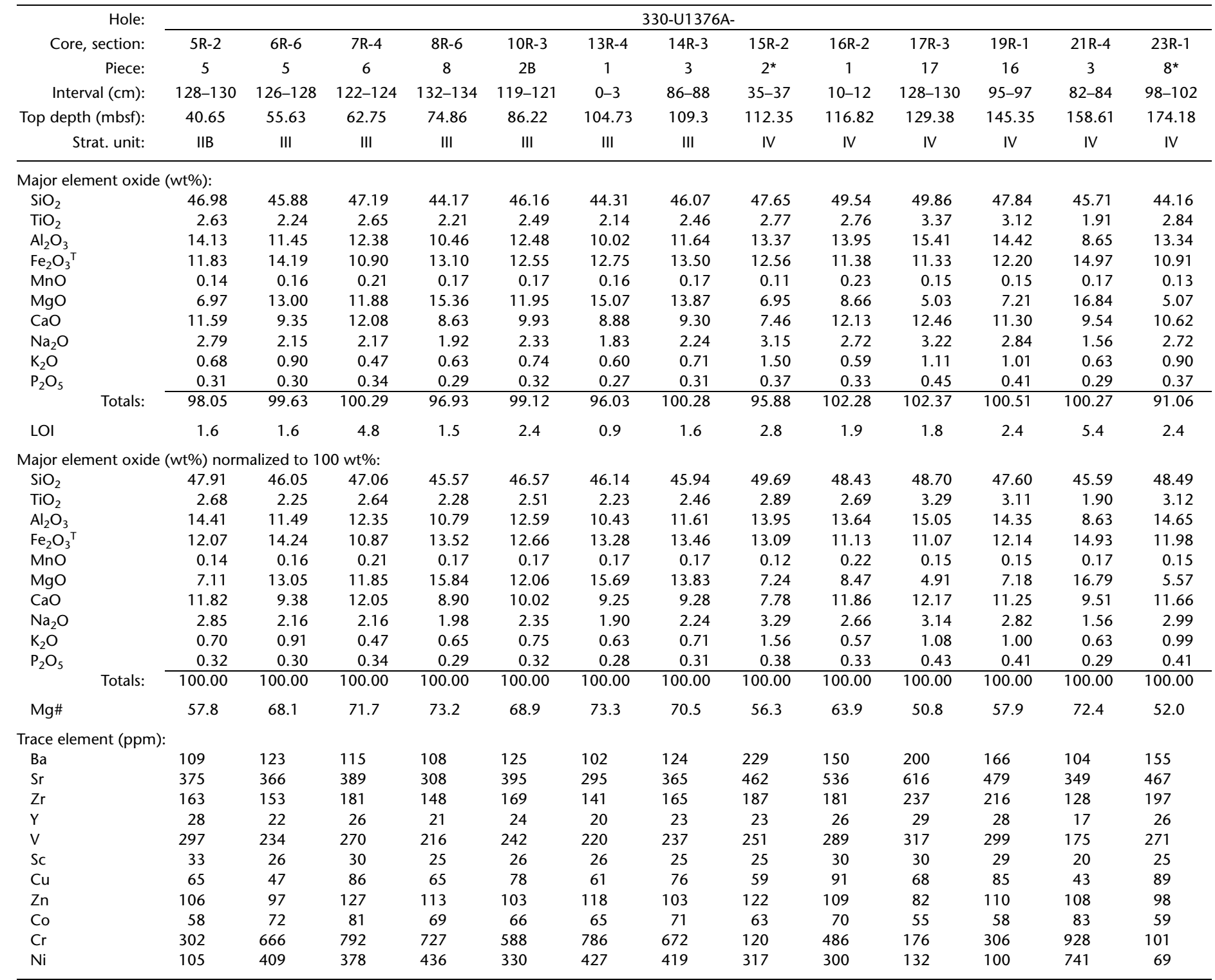

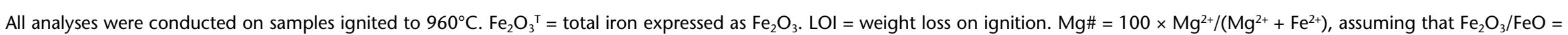


Table T10. Moisture and density measurements, Site U1376. (Continued on next page.)

\begin{tabular}{|c|c|c|c|c|c|c|c|}
\hline \multirow{2}{*}{$\begin{array}{l}\text { Core, section, } \\
\text { interval }(\mathrm{cm})\end{array}$} & \multirow{2}{*}{$\begin{array}{l}\text { Top depth } \\
\text { (mbsf) }\end{array}$} & \multicolumn{3}{|c|}{ Density $\left(\mathrm{g} / \mathrm{cm}^{3}\right)$} & \multirow[b]{2}{*}{ Void ratio } & \multirow{2}{*}{$\begin{array}{l}\text { Water content } \\
\text { (\%) }\end{array}$} & \multirow{2}{*}{$\begin{array}{c}\text { Porosity } \\
\text { (\%) }\end{array}$} \\
\hline & & Bulk & Dry & Grain & & & \\
\hline \multicolumn{8}{|l|}{ 330-U1376A- } \\
\hline 1R-3, 85-87 & 3.60 & 2.305 & 1.997 & 2.855 & 0.430 & 13.36 & 30.08 \\
\hline $1 \mathrm{R}-3,125-127$ & 4.00 & 1.980 & 1.562 & 2.641 & 0.691 & 21.13 & 40.86 \\
\hline $1 \mathrm{R}-4,137-139$ & 5.57 & 2.199 & 1.875 & 2.744 & 0.463 & 14.74 & 31.67 \\
\hline 1R-6, 27-29 & 7.33 & 2.337 & 2.107 & 2.717 & 0.290 & 9.84 & 22.45 \\
\hline $2 \mathrm{R}-2,114-116$ & 11.92 & 1.865 & 1.345 & 2.731 & 1.030 & 27.87 & 50.75 \\
\hline $2 \mathrm{R}-3,57-59$ & 12.80 & 2.051 & 1.659 & 2.688 & 0.620 & 19.10 & 38.27 \\
\hline $2 \mathrm{R}-5,41-43$ & 15.28 & 1.748 & 1.155 & 2.742 & 1.374 & 33.91 & 57.88 \\
\hline $2 \mathrm{R}-6,102-104$ & 17.29 & 2.065 & 1.669 & 2.719 & 0.629 & 19.15 & 38.60 \\
\hline $3 R-2,21-23$ & 20.07 & 1.873 & 1.371 & 2.687 & 0.960 & 26.78 & 48.98 \\
\hline $3 R-3,49-51$ & 21.76 & 2.390 & 2.140 & 2.831 & 0.323 & 10.46 & 24.42 \\
\hline $3 R-4,107-109$ & 23.60 & 2.644 & 2.604 & 2.711 & 0.041 & 1.54 & 3.97 \\
\hline $3 R-5,134-136$ & 25.40 & 2.544 & 2.454 & 2.690 & 0.096 & 3.54 & 8.79 \\
\hline $4 \mathrm{R}-1,22-24$ & 28.82 & 2.689 & 2.666 & 2.726 & 0.022 & 0.84 & 2.20 \\
\hline $4 R-4,71-73$ & 33.58 & 2.593 & 2.549 & 2.664 & 0.045 & 1.71 & 4.34 \\
\hline $5 R-2,78-80$ & 40.15 & 2.324 & 2.009 & 2.900 & 0.444 & 13.54 & 30.72 \\
\hline $5 R-3,57-59$ & 41.29 & 2.252 & 1.926 & 2.824 & 0.466 & 14.45 & 31.77 \\
\hline $5 R-4,79-81$ & 42.85 & 2.236 & 1.902 & 2.822 & 0.484 & 14.93 & 32.60 \\
\hline $5 R-5,108-110$ & 44.48 & 2.217 & 1.873 & 2.822 & 0.507 & 15.53 & 33.63 \\
\hline $5 R-6,77-79$ & 45.66 & 2.501 & 2.270 & 2.932 & 0.292 & 9.25 & 22.58 \\
\hline $5 R-7,37-39$ & 46.51 & 2.335 & 2.034 & 2.882 & 0.417 & 12.90 & 29.43 \\
\hline $5 R-7,78-80$ & 46.92 & 2.526 & 2.316 & 2.914 & 0.258 & 8.31 & 20.51 \\
\hline $6 \mathrm{R}-3,86-88$ & 51.15 & 2.697 & 2.563 & 2.948 & 0.150 & 4.95 & 13.05 \\
\hline $6 \mathrm{R}-4,61-63$ & 52.22 & 2.331 & 2.001 & 2.953 & 0.476 & 14.16 & 32.23 \\
\hline 6R-6, 90-92 & 55.27 & 2.910 & 2.880 & 2.966 & 0.030 & 1.02 & 2.90 \\
\hline $6 \mathrm{R}-7,67-69$ & 56.40 & 2.318 & 2.002 & 2.897 & 0.447 & 13.64 & 30.89 \\
\hline 7R-1, 66-68 & 58.06 & 2.488 & 2.252 & 2.927 & 0.300 & 9.49 & 23.05 \\
\hline $7 \mathrm{R}-2,58-60$ & 59.44 & 2.724 & 2.596 & 2.969 & 0.144 & 4.72 & 12.57 \\
\hline $7 R-6,117-119$ & 65.48 & 2.698 & 2.584 & 2.907 & 0.125 & 4.21 & 11.09 \\
\hline 7R-7, 19-21 & 65.84 & 2.215 & 1.865 & 2.833 & 0.519 & 15.80 & 34.17 \\
\hline $8 R-3,122-124$ & 70.72 & 2.711 & 2.591 & 2.936 & 0.133 & 4.45 & 11.77 \\
\hline 8R-4, 117-119 & 72.03 & 2.978 & 2.948 & 3.036 & 0.030 & 1.00 & 2.91 \\
\hline $8 R-5,82-84$ & 73.03 & 3.001 & 2.980 & 3.043 & 0.021 & 0.71 & 2.07 \\
\hline 8R-8, 112-114 & 77.38 & 2.951 & 2.918 & 3.016 & 0.034 & 1.13 & 3.25 \\
\hline 9R-2, 89-91 & 78.78 & 3.036 & 3.015 & 3.078 & 0.021 & 0.69 & 2.06 \\
\hline $9 R-4,132-134$ & 82.03 & 2.988 & 2.964 & 3.035 & 0.024 & 0.79 & 2.31 \\
\hline 10R-2, 94-96 & 84.73 & 3.045 & 3.029 & 3.077 & 0.016 & 0.52 & 1.55 \\
\hline $11 \mathrm{R}-2,40-42$ & 88.23 & 3.031 & 3.012 & 3.069 & 0.019 & 0.63 & 1.85 \\
\hline 11R-5, 75-77 & 91.80 & 3.068 & 3.053 & 3.097 & 0.015 & 0.48 & 1.43 \\
\hline $12 \mathrm{R}-2,108-110$ & 98.74 & 2.998 & 2.981 & 3.033 & 0.018 & 0.59 & 1.74 \\
\hline $12 \mathrm{R}-4,133-135$ & 101.62 & 3.060 & 3.046 & 3.087 & 0.013 & 0.44 & 1.31 \\
\hline 13R-1, 67-69 & 101.87 & 3.049 & 3.036 & 3.075 & 0.013 & 0.43 & 1.29 \\
\hline $13 R-4,10-12$ & 104.83 & 3.099 & 3.087 & 3.123 & 0.012 & 0.39 & 1.18 \\
\hline $14 \mathrm{R}-1,103-105$ & 107.03 & 2.146 & 1.915 & 2.474 & 0.292 & 10.79 & 22.60 \\
\hline $14 \mathrm{R}-2,60-62$ & 107.83 & 2.109 & 1.904 & 2.382 & 0.251 & 9.75 & 20.09 \\
\hline $14 \mathrm{R}-3,2-4$ & 108.46 & 3.009 & 2.994 & 3.039 & 0.015 & 0.51 & 1.49 \\
\hline $14 \mathrm{R}-4,29-31$ & 109.96 & 2.756 & 2.656 & 2.943 & 0.108 & 3.62 & 9.75 \\
\hline $15 R-2,18-20$ & 112.18 & 2.681 & 2.561 & 2.900 & 0.132 & 4.47 & 11.70 \\
\hline $15 R-3,12-14$ & 113.52 & 2.598 & 2.420 & 2.928 & 0.210 & 6.84 & 17.35 \\
\hline 15R-4, 89-91 & 115.30 & 1.951 & 1.658 & 2.321 & 0.400 & 15.00 & 28.58 \\
\hline $16 \mathrm{R}-1,48-50$ & 116.08 & 2.158 & 1.910 & 2.520 & 0.320 & 11.50 & 24.23 \\
\hline 16R-3, 134-136 & 119.21 & 2.662 & 2.565 & 2.834 & 0.105 & 3.65 & 9.49 \\
\hline $16 \mathrm{R}-4,30-32$ & 119.62 & 2.126 & 1.896 & 2.444 & 0.289 & 10.80 & 22.42 \\
\hline $16 \mathrm{R}-6,60-62$ & 122.65 & 2.363 & 2.165 & 2.685 & 0.240 & 8.38 & 19.35 \\
\hline 17R-1, 80-82 & 126.00 & 2.364 & 2.126 & 2.769 & 0.302 & 10.05 & 23.21 \\
\hline 17R-2, 95-97 & 127.59 & 2.539 & 2.289 & 3.030 & 0.324 & 9.87 & 24.46 \\
\hline $17 R-3,101-103$ & 129.11 & 2.623 & 2.456 & 2.934 & 0.195 & 6.36 & 16.29 \\
\hline 19R-2, 86-88 & 146.69 & 2.913 & 2.890 & 2.958 & 0.023 & 0.81 & 2.30 \\
\hline $19 R-3,43-45$ & 147.69 & 2.236 & 1.883 & 2.874 & 0.526 & 15.79 & 34.49 \\
\hline 20R-2, 58-60 & 150.17 & 2.356 & 2.055 & 2.911 & 0.417 & 12.79 & 29.42 \\
\hline $20 \mathrm{R}-4,91-93$ & 153.14 & 2.604 & 2.388 & 3.029 & 0.269 & 8.33 & 21.18 \\
\hline $21 \mathrm{R}-1,21-23$ & 154.21 & 2.702 & 2.583 & 2.921 & 0.131 & 4.39 & 11.58 \\
\hline 21R-3, 17-19 & 156.64 & 2.647 & 2.494 & 2.931 & 0.175 & 5.77 & 14.92 \\
\hline 21R-4, 113-115 & 158.92 & 2.862 & 2.783 & 3.015 & 0.083 & 2.75 & 7.68 \\
\hline 21R-5, 71-73 & 159.95 & 2.576 & 2.351 & 3.013 & 0.281 & 8.73 & 21.97 \\
\hline $22 \mathrm{R}-1,94-96$ & 164.54 & 2.668 & 2.489 & 3.016 & 0.212 & 6.70 & 17.46 \\
\hline 22R-1, 101-103 & 164.61 & 2.444 & 2.190 & 2.914 & 0.331 & 10.41 & 24.85 \\
\hline $22 \mathrm{R}-3,61-63$ & 167.02 & 2.607 & 2.448 & 2.897 & 0.183 & 6.09 & 15.50 \\
\hline
\end{tabular}


Table T10 (continued).

\begin{tabular}{|c|c|c|c|c|c|c|c|}
\hline \multirow{2}{*}{$\begin{array}{l}\text { Core, section, } \\
\text { interval }(\mathrm{cm})\end{array}$} & \multirow{2}{*}{$\begin{array}{c}\text { Top depth } \\
\text { (mbsf) }\end{array}$} & \multicolumn{3}{|c|}{ Density $\left(\mathrm{g} / \mathrm{cm}^{3}\right)$} & \multirow[b]{2}{*}{ Void ratio } & \multirow{2}{*}{$\begin{array}{l}\text { Water content } \\
\text { (\%) }\end{array}$} & \multirow{2}{*}{$\begin{array}{c}\text { Porosity } \\
\text { (\%) }\end{array}$} \\
\hline & & Bulk & Dry & Grain & & & \\
\hline $22 \mathrm{R}-5,62-64$ & 169.86 & 2.471 & 2.269 & 2.829 & 0.247 & 8.20 & 19.80 \\
\hline $23 \mathrm{R}-1,38-40$ & 173.58 & 2.727 & 2.643 & 2.880 & 0.090 & 3.09 & 8.23 \\
\hline $23 R-4,54-56$ & 177.73 & 2.767 & 2.719 & 2.853 & 0.050 & 1.75 & 4.72 \\
\hline $23 \mathrm{R}-6,29-31$ & 179.86 & 2.760 & 2.702 & 2.862 & 0.059 & 2.07 & 5.58 \\
\hline
\end{tabular}

Water content is relative to wet mass.

Table T11. Compressional wave velocity measurements, Site U1376. (Continued on next page.)

\begin{tabular}{|c|c|c|c|c|c|}
\hline \multirow{2}{*}{$\begin{array}{l}\text { Core, section, } \\
\text { interval }(\mathrm{cm})\end{array}$} & \multirow{2}{*}{$\begin{array}{l}\text { Top depth } \\
\text { (mbsf) }\end{array}$} & \multicolumn{4}{|c|}{ Velocity $(\mathrm{km} / \mathrm{s})$} \\
\hline & & $x$ & $y$ & $z$ & Average \\
\hline \multicolumn{6}{|l|}{ 330-U1376A- } \\
\hline 1R-3, 85-87 & 3.60 & 3.503 & 3.476 & 3.405 & 3.461 \\
\hline $1 \mathrm{R}-3,125-127$ & 4.00 & 3.173 & 3.168 & 3.113 & 3.151 \\
\hline $1 \mathrm{R}-4,137-139$ & 5.57 & 3.204 & 3.283 & 3.275 & 3.254 \\
\hline 1R-6, 27-29 & 7.33 & 4.230 & 4.159 & 4.064 & 4.151 \\
\hline 2R-2, 114-116 & 11.92 & 2.099 & 2.077 & 2.018 & 2.065 \\
\hline $2 R-3,57-59$ & 12.80 & 3.177 & 3.142 & 3.076 & 3.132 \\
\hline $2 \mathrm{R}-5,41-43$ & 15.28 & 2.106 & 2.043 & 2.052 & 2.067 \\
\hline $2 R-6,102-104$ & 17.29 & 2.968 & 2.995 & 2.970 & 2.978 \\
\hline $3 R-2,21-23$ & 20.07 & 1.835 & 1.798 & 1.708 & 1.780 \\
\hline $3 R-3,49-51$ & 21.76 & 3.741 & 3.734 & 3.593 & 3.690 \\
\hline $3 R-4,107-109$ & 23.60 & 6.506 & 6.400 & 6.370 & 6.425 \\
\hline $3 R-5,134-136$ & 25.40 & 5.390 & 5.351 & 5.265 & 5.335 \\
\hline 4R-1, 22-24 & 28.82 & 6.667 & 6.857 & 6.842 & 6.788 \\
\hline $4 \mathrm{R}-4,71-73$ & 33.58 & 6.337 & 6.202 & 6.134 & 6.224 \\
\hline $5 R-2,78-80$ & 40.15 & 3.246 & 3.220 & 3.136 & 3.201 \\
\hline $5 R-3,57-59$ & 41.29 & 3.168 & 3.128 & 3.106 & 3.134 \\
\hline $5 R-4,79-81$ & 42.85 & 3.073 & 3.094 & 3.101 & 3.089 \\
\hline $5 R-5,108-110$ & 44.48 & 2.684 & 2.667 & 2.633 & 2.661 \\
\hline $5 R-6,77-79$ & 45.66 & 3.941 & 3.805 & 3.877 & 3.874 \\
\hline $5 R-7,37-39$ & 46.51 & 3.571 & 3.510 & 3.467 & 3.516 \\
\hline $5 R-7,78-80$ & 46.92 & 3.940 & 4.050 & 3.925 & 3.972 \\
\hline $6 \mathrm{R}-3,86-88$ & 51.15 & 4.464 & 4.445 & 4.574 & 4.494 \\
\hline $6 \mathrm{R}-4,61-63$ & 52.22 & 2.751 & 2.767 & 2.745 & 2.754 \\
\hline 6R-6, 90-92 & 55.27 & 6.456 & 6.341 & 6.393 & 6.397 \\
\hline 6R-7, 67-69 & 56.40 & 3.325 & 3.311 & 3.286 & 3.307 \\
\hline 7R-1, 66-68 & 58.06 & 3.039 & 3.236 & 3.126 & 3.134 \\
\hline 7R-2, 58-60 & 59.44 & 4.505 & 4.540 & 4.431 & 4.492 \\
\hline 7R-6, 117-119 & 65.48 & 4.661 & 4.684 & 4.590 & 4.645 \\
\hline 7R-7, 19-21* & 65.84 & 2.412 & ND & ND & 2.412 \\
\hline $8 R-3,122-124$ & 70.72 & 4.820 & 4.603 & 4.619 & 4.681 \\
\hline $8 R-4,117-119$ & 72.03 & 6.470 & 6.465 & 6.414 & 6.450 \\
\hline $8 R-5,82-84$ & 73.03 & 6.757 & 6.619 & 6.630 & 6.669 \\
\hline 8R-8, 112-114 & 77.38 & 6.382 & 6.271 & 6.255 & 6.303 \\
\hline 9R-2, 89-91 & 78.78 & 6.862 & 6.810 & 6.710 & 6.794 \\
\hline $9 R-4,132-134$ & 82.03 & 6.807 & 6.704 & 6.688 & 6.733 \\
\hline 10R-2, 94-96 & 84.73 & 6.962 & 6.940 & 6.956 & 6.952 \\
\hline $11 \mathrm{R}-2,40-42$ & 88.23 & 6.822 & 6.778 & 6.738 & 6.779 \\
\hline 11R-5, 75-77 & 91.80 & 7.205 & 7.057 & 7.132 & 7.132 \\
\hline $12 \mathrm{R}-2,108-110$ & 98.74 & 7.273 & 7.192 & 7.152 & 7.206 \\
\hline $12 R-4,133-135$ & 101.62 & 7.025 & 6.964 & 6.925 & 6.971 \\
\hline 13R-1, 67-69 & 101.87 & 7.101 & 6.982 & 6.857 & 6.980 \\
\hline 13R-4, 10-12 & 104.83 & 7.260 & 7.111 & 7.125 & 7.166 \\
\hline 14R-1, 103-105 & 107.03 & 4.102 & 4.135 & 4.166 & 4.134 \\
\hline $14 \mathrm{R}-2,60-62$ & 107.83 & 3.921 & 3.866 & 3.967 & 3.918 \\
\hline $14 R-3,2-4$ & 108.46 & 7.086 & 6.968 & 6.965 & 7.007 \\
\hline $14 \mathrm{R}-4,29-31$ & 109.96 & 4.962 & 4.601 & 4.588 & 4.717 \\
\hline 15R-2, 18-20 & 112.18 & 5.160 & 4.998 & 5.099 & 5.086 \\
\hline $15 R-3,12-14$ & 113.52 & 4.245 & 4.213 & 4.313 & 4.257 \\
\hline 15R-4, 89-91 & 115.30 & 3.613 & 3.553 & 3.612 & 3.593 \\
\hline $16 \mathrm{R}-1,48-50$ & 116.08 & 3.908 & 3.882 & 3.867 & 3.886 \\
\hline $16 \mathrm{R}-4,30-32$ & 119.62 & 3.583 & 3.541 & 3.538 & 3.554 \\
\hline $16 \mathrm{R}-6,60-62$ & 122.65 & 4.611 & 4.555 & 4.619 & 4.595 \\
\hline
\end{tabular}


Table T11 (continued).

\begin{tabular}{lccccc}
\hline \multirow{2}{*}{$\begin{array}{c}\text { Core, section, } \\
\text { interval }(\mathrm{cm})\end{array}$} & $\begin{array}{c}\text { Top depth } \\
(\mathrm{mbsf})\end{array}$ & $x$ & $y$ & $z$ & Average \\
\cline { 3 - 6 } & & & & & \\
& & & & & \\
17R-1, 80-82 & 126.00 & 3.713 & 3.651 & 3.645 & 3.670 \\
17R-2, 95-97 & 127.59 & 4.413 & 4.235 & 4.095 & 4.247 \\
17R-3, 101-103 & 129.11 & 5.087 & 4.952 & 4.704 & 4.915 \\
19R-2, 86-88 & 146.69 & 6.665 & 6.610 & 6.630 & 6.635 \\
19R-3, 43-45 & 147.69 & 2.705 & 2.787 & 2.739 & 2.744 \\
20R-2, 58-60 & 150.17 & 2.916 & 3.000 & 2.985 & 2.967 \\
20R-4, 91-93 & 153.14 & 4.177 & 4.114 & 4.122 & 4.138 \\
21R-1, 21-23 & 154.21 & 4.911 & 4.844 & 4.816 & 4.857 \\
21R-3, 17-19 & 156.64 & 4.680 & 4.675 & 4.685 & 4.680 \\
21R-4, 113-115 & 158.92 & 5.437 & 5.398 & 5.362 & 5.399 \\
21R-5, 71-73 & 159.95 & 4.194 & 4.296 & 4.188 & 4.226 \\
22R-1, 94-96 & 164.54 & 4.683 & 4.648 & 4.659 & 4.663 \\
22R-1, 101-103 & 164.61 & 3.738 & 3.822 & 3.726 & 3.762 \\
22R-3, 61-63 & 167.02 & 5.150 & 5.143 & 5.214 & 5.169 \\
22R-5, 62-64 & 169.86 & 3.949 & 3.970 & 3.884 & 3.934 \\
23R-1, 38-40 & 173.58 & 5.662 & 5.505 & 5.683 & 5.617 \\
23R-4, 54-56 & 177.73 & 6.157 & 6.051 & 6.154 & 6.121 \\
23R-6, 29-31 & 179.86 & 6.379 & 6.377 & 6.526 & 6.427 \\
\hline
\end{tabular}

Values are accurate to $\pm 20 \mathrm{~m} / \mathrm{s}$. ND = no data (shape of Sample 330-U1376A-7R-7, 19-21 cm, did not allow $P$-wave velocity measurements for $y$ and $z$-axes).

Table T12. Magnetic properties and demagnetization results for discrete samples, Hole U1376A. This table is available in an oversized format.

Table T13. Anisotropy of magnetic susceptibility results for discrete samples, Hole U1376A. This table is available in an oversized format. 
Table T14. Inclination-only averages for lithologic units, Hole U1376A. (Continued on next page.)

\begin{tabular}{|c|c|c|c|c|c|c|c|c|c|c|c|c|c|c|c|}
\hline \multirow[b]{3}{*}{$\begin{array}{c}\text { Strat. } \\
\text { unit }\end{array}$} & \multirow[b]{3}{*}{$\begin{array}{l}\text { Lith. } \\
\text { unit }\end{array}$} & \multirow[b]{3}{*}{$\mathrm{ISCl}$} & \multirow[b]{3}{*}{ Lithology } & & & \multicolumn{5}{|c|}{ Averages from $2 \mathrm{~cm}$ archive-half core data } & \multicolumn{5}{|c|}{ Averages from Fisher piece averages } \\
\hline & & & & \multirow{2}{*}{\multicolumn{2}{|c|}{ Lith. unit depth (mbsf) }} & \multirow[b]{2}{*}{$n$} & \multicolumn{2}{|c|}{ Inclination $\left(^{\circ}\right)$} & \multirow[b]{2}{*}{$\alpha_{63}$} & \multirow[b]{2}{*}{$\alpha_{95}$} & \multirow[b]{2}{*}{$n$} & \multicolumn{2}{|c|}{ Inclination $\left(^{\circ}\right)$} & \multirow[b]{2}{*}{$\alpha_{63}$} & \multirow[b]{2}{*}{$\alpha_{95}$} \\
\hline & & & & & & & $\begin{array}{l}\text { Arithmetic } \\
\text { mean }\end{array}$ & $\begin{array}{l}\text { Maximum } \\
\text { likelihood }\end{array}$ & & & & $\begin{array}{l}\text { Arithmetic } \\
\text { mean }\end{array}$ & $\begin{array}{l}\text { Maximum } \\
\text { likelihood }\end{array}$ & & \\
\hline IA & - & NA & Sediment & 0.00 & 1.52 & & & & & & & & & & \\
\hline IB & - & NA & Sediment & 1.52 & 4.50 & & & & & & & & & & \\
\hline IC & - & NA & Sediment & 4.50 & 21.48 & 11 & 67.1 & 67.8 & 8.2 & 4.6 & 4 & 68.5 & 69.1 & 7.2 & 8.2 \\
\hline ID & - & NA & Sediment & 21.48 & 23.45 & 2 & 71.9 & 71.9 & 1.6 & 4.8 & 1 & 72.0 & & & \\
\hline IIA & - & NA & Sediment & 23.45 & 38.60 & 6 & 68.6 & 69.1 & 6.6 & 5.4 & 3 & 68.6 & 69.0 & 6.1 & 9.3 \\
\hline IIB & - & NA & Sediment & 38.60 & 41.93 & $18^{\dagger}$ & & & & & 3 & 35.8 & 57.3 & 54.4 & 112.2 \\
\hline III & 1 & NA & Hyaloclastite & 41.93 & 45.19 & & & & & & & & & & \\
\hline IIII & 2 & NA & Vesicular basalt & 45.19 & 46.15 & & & & & & & & & & \\
\hline III & 3 & NA & Heterolithic breccia & 46.15 & 46.75 & 10 & 36.8 & 46.9 & 42.3 & 28.6 & & & & & \\
\hline III & 4 & 3 & Basalt with thin breccia intervals & 46.75 & 50.37 & 4 & 63.2 & 64.0 & 9.7 & 11.1 & 2 & 69.2 & 74.7 & 17.3 & 56.1 \\
\hline III & 5 & 3 & Basalt & 50.37 & 51.48 & & & & & & & & & & \\
\hline III & 6 & 3 & Basalt with thin breccia intervals & 51.48 & 51.99 & & & & & & & & & & \\
\hline III & 7 & NA & Basalt breccia & 51.99 & 52.56 & & & & & & & & & & \\
\hline III & 8 & 1 & Basalt & 52.56 & 52.93 & & & & & & & & & & \\
\hline III & 9 & NA & Basalt breccia & 52.93 & 53.02 & & & & & & & & & & \\
\hline III & 10 & 1 & Basalt & 53.02 & 53.70 & 1 & 45.7 & & & & 1 & 45.7 & & & \\
\hline III & 11 & NA & Basalt breccia & 53.70 & 55.24 & $4^{\dagger}$ & & & & & 1 & -21.6 & & & \\
\hline III & 12 & 1 & Basalt & 55.24 & 55.96 & 21 & 72.4 & 73.2 & 7.6 & 3.0 & 3 & 72.5 & 73.1 & 6.3 & 9.6 \\
\hline III & 13 & NA & Basalt breccia & 55.96 & 57.50 & 3 & -3.9 & -3.9 & 3.7 & 5.6 & 1 & -3.9 & & & \\
\hline III & 14 & 2 & Basalt lava with breccia intervals & 57.50 & 72.21 & $128(130)^{*}$ & 72.5 & 74.0 & 9.6 & 1.5 & $10^{\dagger}$ & & & & \\
\hline III & 15 & 3 & Massive basalt & 72.21 & 105.32 & 909 & 71.3 & 71.9 & 6.6 & 0.4 & 95 & 69.8 & 70.1 & 5.2 & 0.9 \\
\hline III & 16 & NA & Hyaloclastite breccia & 105.32 & 108.07 & & & & & & & & & & \\
\hline III & 17 & 3 & Massive basalt & 108.07 & 110.14 & 78 & 67.2 & 68.1 & 8.8 & 1.8 & 3 & 68.2 & 68.4 & 4.1 & 6.2 \\
\hline IV & 18 & 1 & Intrusive sheet & 110.14 & 110.22 & 1 & 55.2 & & & & & & & & \\
\hline IV & 19 & NA & Hyaloclastite breccia & 110.22 & 112.00 & 1 & 59.8 & & & & 2 & 64.5 & 64.9 & 6.6 & 20.6 \\
\hline IV & 20 & 3 & Intrusive sheet & 112.00 & 112.78 & 22 & 57.7 & 58.2 & 7.7 & 3.0 & 1 & 44.4 & & & \\
\hline IV & 21 & NA & Hyaloclastite breccia & 112.78 & 127.57 & 14 & 62.1 & 63.0 & 10.2 & 5.0 & 3 & 58.9 & 59.3 & 6.8 & 10.5 \\
\hline IV & 22 & 1 & Lava lobe or fragment & 127.57 & 128.09 & 2 & 20.7 & 20.7 & 4.2 & 12.9 & 1 & 20.7 & & & \\
\hline IV & 23 & NA & Hyaloclastite breccia & 128.09 & 128.33 & & & & & & & & & & \\
\hline IV & 24 & 2 & Lava lobe or fragment & 128.33 & 129.93 & & & & & & & & & & \\
\hline IV & 25 & 0 & Lava lobe or fragment & 129.93 & 130.00 & & & & & & & & & & \\
\hline IV & 26 & NA & Heterolithic basalt breccia & 134.80 & 135.68 & & & & & & & & & & \\
\hline IV & 27 & 0 & Lava lobe or fragment & 135.68 & 135.88 & & & & & & & & & & \\
\hline IV & 28 & NA & Heterolithic basalt breccia & 144.40 & 145.32 & & & & & & & & & & \\
\hline IV & 29 & 3 & Lava lobe or fragment & 145.32 & 147.11 & 41 & 68.8 & 69.3 & 6.7 & 1.9 & 5 & 65.3 & 65.7 & 6.7 & 6.3 \\
\hline IV & 30 & NA & Heterolithic basalt breccia & 147.11 & 156.09 & $77^{\dagger}$ & & & & & $23^{\dagger}$ & & & & \\
\hline IV & 31 & 1 & $\begin{array}{l}\text { Vesiculated basalt lava lobe or } \\
\text { fragment }\end{array}$ & 156.09 & 157.08 & 4 & -4.4 & -4.4 & 4.1 & 4.6 & 2 & -2.8 & -2.8 & 4.6 & 14.2 \\
\hline IV & 32 & NA & Volcanic breccia and hyaloclastite & 157.08 & 158.11 & 7 & 43.7 & 52.7 & 36.4 & 29.7 & $3^{\dagger}$ & & & & \\
\hline IV & 33 & 2 & Lava lobe or fragment & 158.11 & 160.13 & 7 & 57.0 & 57.6 & 8.7 & 6.6 & 1 & 57.1 & & & \\
\hline IV & 34 & NA & $\begin{array}{l}\text { Heterolithic basalt breccia with } \\
\text { hyaloclastite matrix }\end{array}$ & 160.13 & 165.14 & 13 & 60.3 & 61.2 & 10.7 & 5.5 & 2 & 57.9 & 58.2 & 6.7 & 20.7 \\
\hline IV & 35 & 1 & Lava lobe or fragment & 165.14 & 165.60 & 19 & 58.6 & 63.1 & 21.1 & 9.0 & 1 & 58.9 & & & \\
\hline IV & 36 & NA & $\begin{array}{l}\text { Heterolithic basalt breccia with } \\
\text { hyaloclastite matrix }\end{array}$ & 165.60 & 166.50 & 3 & 65.6 & 65.7 & 3.2 & 4.8 & 1 & 65.7 & & & \\
\hline IV & 37 & 1 & $\begin{array}{l}\text { Vesiculated basalt lava lobe or } \\
\text { fragment }\end{array}$ & 166.50 & 167.23 & 15 & 63.8 & 64.3 & 7.5 & 3.6 & 4 & 62.5 & 62.9 & 7.3 & 8.3 \\
\hline
\end{tabular}


Table T14 (continued).

\begin{tabular}{|c|c|c|c|c|c|c|c|c|c|c|c|c|c|c|c|}
\hline \multirow[b]{3}{*}{$\begin{array}{c}\text { Strat. } \\
\text { unit }\end{array}$} & \multirow[b]{3}{*}{$\begin{array}{l}\text { Lith. } \\
\text { unit }\end{array}$} & \multirow[b]{3}{*}{$\mathrm{ISCl}$} & \multirow[b]{3}{*}{ Lithology } & \multirow{2}{*}{\multicolumn{2}{|c|}{ Lith. unit depth (mbsf) }} & \multicolumn{5}{|c|}{ Averages from $2 \mathrm{~cm}$ archive-half core data } & \multicolumn{5}{|c|}{ Averages from Fisher piece averages } \\
\hline & & & & & & \multirow[b]{2}{*}{$n$} & \multicolumn{2}{|c|}{ Inclination $\left(^{\circ}\right)$} & \multirow[b]{2}{*}{$\alpha_{63}$} & \multirow[b]{2}{*}{$\alpha_{95}$} & \multirow[b]{2}{*}{$n$} & \multicolumn{2}{|c|}{ Inclination $\left(^{\circ}\right)$} & \multirow[b]{2}{*}{$\alpha_{63}$} & \multirow[b]{2}{*}{$\alpha_{95}$} \\
\hline & & & & $\frac{\text { Lith. unit d }}{\text { Top }}$ & $\frac{\text { th (mbsf) }}{\text { Bottom }}$ & & $\begin{array}{c}\text { Arithmetic } \\
\text { mean }\end{array}$ & $\begin{array}{l}\text { Maximum } \\
\text { likelihood }\end{array}$ & & & & $\begin{array}{l}\text { Arithmetic } \\
\text { mean }\end{array}$ & $\begin{array}{l}\text { Maximum } \\
\text { likelihood }\end{array}$ & & \\
\hline IV & 38 & NA & $\begin{array}{l}\text { Volcanic breccia with hyaloclastite } \\
\text { matrix }\end{array}$ & 167.23 & 167.47 & 1 & 74.7 & & & & & & & & \\
\hline IV & 39 & 1 & Lava lobe or fragment & 167.47 & 167.78 & 2 & 15.4 & 15.4 & 2.3 & 7.2 & & & & & \\
\hline IV & 40 & NA & $\begin{array}{l}\text { Volcanic breccia with hyaloclastite } \\
\text { matrix }\end{array}$ & 167.78 & 170.80 & 15 & 59.6 & 60.1 & 8.5 & 4.0 & 9 & 60.4 & 60.9 & 8.1 & 5.2 \\
\hline IV & 41 & 3 & Intrusive sheet & 170.80 & 179.76 & 138 & 67.6 & 71.1 & 15.0 & 2.3 & $25(26)^{\star}$ & 64.8 & 65.6 & 8.8 & 3.2 \\
\hline IV & 42 & NA & Basalt breccia & 179.76 & 181.07 & 1 & 80.2 & & & & 1 & 80.2 & & & \\
\hline
\end{tabular}

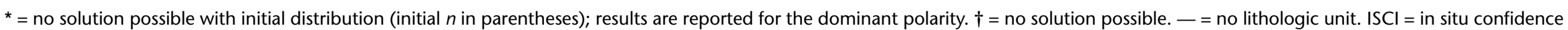

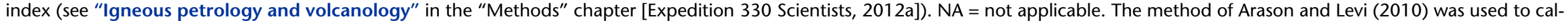
culate inclination-only mean and associated statistics. $\alpha_{63}=$ circular standard deviation, $\alpha_{95}=95 \%$ confidence angle. 
Table T15. Culturing efforts, Hole U1376A.

\begin{tabular}{|c|c|c|c|}
\hline $\begin{array}{l}\text { Core, section, } \\
\text { interval }(\mathrm{cm})\end{array}$ & Media & $\begin{array}{c}\text { Vials } \\
\text { inoculated } \\
(N)\end{array}$ & Growth \\
\hline \multicolumn{4}{|l|}{ 330-U1376A- } \\
\hline \multirow[t]{4}{*}{$2 \mathrm{R}-3,0-6$} & Heterotrophs; 1\% marine broth (low oxygen) & 2 & + \\
\hline & Heterotrophs; 10\% marine broth (low oxygen) & 2 & ++ \\
\hline & Heterotrophs; $1 \%$ marine broth (saturated oxygen) & 2 & ++ \\
\hline & Heterotrophs; $10 \%$ marine broth (saturated oxygen) & 2 & ++ \\
\hline \multirow[t]{4}{*}{$4 \mathrm{R}-1,35-42$} & Heterotrophs; 1\% marine broth (low oxygen) & 2 & - \\
\hline & Heterotrophs; $10 \%$ marine broth (low oxygen) & 2 & - \\
\hline & Heterotrophs; $1 \%$ marine broth (saturated oxygen) & 2 & Maybe \\
\hline & Heterotrophs; $10 \%$ marine broth (saturated oxygen) & 2 & ++ \\
\hline \multirow[t]{9}{*}{$16 \mathrm{R}-5,0-13$} & Autotrophic S oxidizers & 2 & - \\
\hline & Heterotrophic S oxidizers & 2 & Maybe \\
\hline & Autotrophic Fe reducers & 2 & ND \\
\hline & Heterotrophic Fe reducers & 2 & ND \\
\hline & Autotrophic Fe oxidizers & 2 & ND \\
\hline & Heterotrophs; 1\% marine broth (low oxygen) & 2 & ++ \\
\hline & Heterotrophs; $10 \%$ marine broth (low oxygen) & 2 & - \\
\hline & Heterotrophs; 1\% marine broth (saturated oxygen) & 2 & Maybe \\
\hline & Heterotrophs; $10 \%$ marine broth (saturated oxygen) & 2 & - \\
\hline \multirow[t]{10}{*}{$17 R-2,112-120$} & Autotrophic S oxidizers & 2 & ++ \\
\hline & Heterotrophic $\mathrm{S}$ oxidizers & 2 & ++ \\
\hline & Autotrophic Fe reducers & 2 & ND \\
\hline & Heterotrophic Fe reducers & 2 & ND \\
\hline & Autotrophic Fe oxidizers & 2 & ND \\
\hline & Heterotrophs; 1\% marine broth (low oxygen) & 2 & ++ \\
\hline & Heterotrophs; 10\% marine broth (low oxygen) & 2 & ++ \\
\hline & Heterotrophs; $1 \%$ marine broth (saturated oxygen) & 2 & ++ \\
\hline & Heterotrophs; $10 \%$ marine broth (saturated oxygen) & 2 & ++ \\
\hline & Heterotrophic sulfur-oxidizing bacteria & 2 & ++ \\
\hline \multirow[t]{9}{*}{$23 \mathrm{R}-1,102-114$} & Autotrophic $\mathrm{S}$ oxidizers & 2 & Maybe \\
\hline & Heterotrophic S oxidizers & 2 & Maybe \\
\hline & Autotrophic Fe reducers & 2 & ND \\
\hline & Heterotrophic Fe reducers & 2 & ND \\
\hline & Autotrophic Fe oxidizers & 2 & ND \\
\hline & Heterotrophs; $1 \%$ marine broth (low oxygen) & 2 & Maybe \\
\hline & Heterotrophs; 10\% marine broth (low oxygen) & 2 & ++ \\
\hline & Heterotrophs; $1 \%$ marine broth (saturated oxygen) & 2 & Maybe \\
\hline & Heterotrophs; $10 \%$ marine broth (saturated oxygen) & 2 & Maybe \\
\hline
\end{tabular}

Analysis of growth was determined by shaking the vials. If turbidity was greater than in the initial sample, growth was considered positive. $++=$ both vials were positive,$+=$ one vial was positive,$-=$ no growth. ND $=$ not determined (media targeting iron reducers and iron oxidizers contain particulates, and therefore a change in turbidity was impossible to detect).

Table T16. Samples used for stable isotope addition bioassays, Hole U1376A.

\begin{tabular}{|c|c|c|c|}
\hline $\begin{array}{l}\text { Core, section, } \\
\text { interval }(\mathrm{cm})\end{array}$ & Treatment & $\begin{array}{l}\text { Vials } \\
(N)\end{array}$ & $\begin{array}{l}\text { Approximate volume } \\
\text { of rocks per vial }\left(\mathrm{cm}^{3}\right)\end{array}$ \\
\hline \multicolumn{4}{|l|}{ 330-U1376A- } \\
\hline \multirow[t]{2}{*}{ 7R-3, 59-71 } & $\begin{array}{l}+2.71 \mathrm{mM}^{13} \mathrm{C} \text { bicarbonate } \\
+300 \mu \mathrm{M}{ }^{34} \mathrm{~S} \text { elemental } \mathrm{S} \\
+0.5 \mu \mathrm{M}{ }^{15} \mathrm{~N} \text { ammonia }\end{array}$ & 5 & 30 \\
\hline & $\begin{array}{l}+2.71 \mathrm{mM}^{13} \mathrm{C} \text { bicarbonate } \\
+300 \mu \mathrm{M}^{34} \mathrm{~S} \text { elemental } \mathrm{S} \\
+0.5 \mu \mathrm{M}{ }^{15} \mathrm{~N} \text { ammonia }\end{array}$ & 2 (dead) & 30 \\
\hline \multirow[t]{2}{*}{ 23R-1, 102-114 } & $\begin{array}{l}+2.71 \mathrm{mM}^{13} \mathrm{C} \text { bicarbonate } \\
+300 \mu \mathrm{M}^{34} \mathrm{~S} \text { elemental } \mathrm{S} \\
+0.5 \mu \mathrm{M}{ }^{15} \mathrm{~N} \text { ammonia }\end{array}$ & 5 & 13 \\
\hline & $\begin{array}{l}+2.71 \mathrm{mM}^{13} \mathrm{C} \text { bicarbonate } \\
+300 \mu \mathrm{M}^{34} \mathrm{~S} \text { elemental } \mathrm{S} \\
+0.5 \mu \mathrm{M}{ }^{15} \mathrm{~N} \text { ammonia }\end{array}$ & 1 (dead) & 13 \\
\hline
\end{tabular}

